\title{
Geology and Ground Water Resources of the Middle Peninsula, Virginia
}

by
D. J. Cederstrom
Hydrologist
U. S. Geological Survey

\section{BULIETIN}

VIRGINIA DIVISION OF MIIVERAI RESOURCES CEARLOTIESVIILE, VA.

Prepared in cooperation with the

Geological Survey

United States Department of the Interior 
Open-File Report 69-37

NOTE: This is absolutely the very best this report can be copied. The original was not good at all.

HAND NUMBERIEG IN LOWER RIGHT LORNER FOR TEXT \# SEQUENCE 


$$
\begin{aligned}
& \text { G.IT STITS }
\end{aligned}
$$

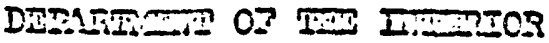

$$
\begin{aligned}
& \text { EOICEICAI STAJIS } \\
& \text { IAD IESCTECS DIVISEOS } \\
& \text { Vashirgion, D.C. ECał+2 } \\
& \text { Alijist 5, 1559 }
\end{aligned}
$$

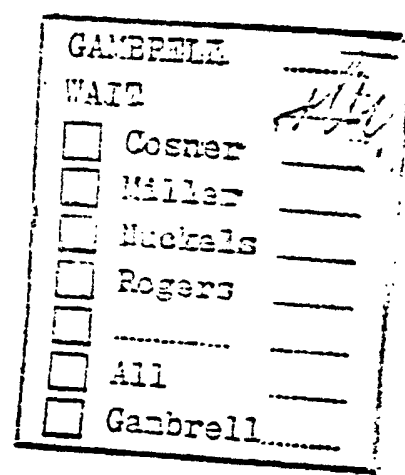

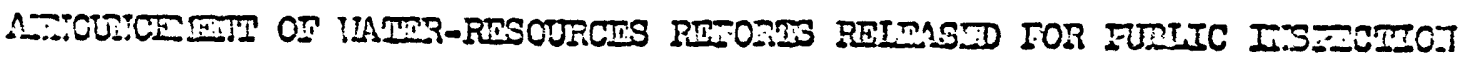

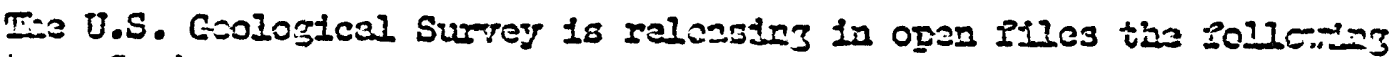

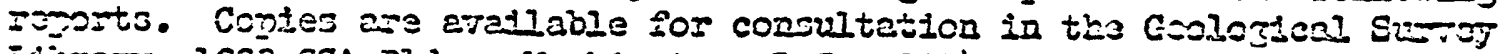

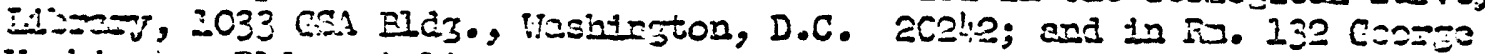

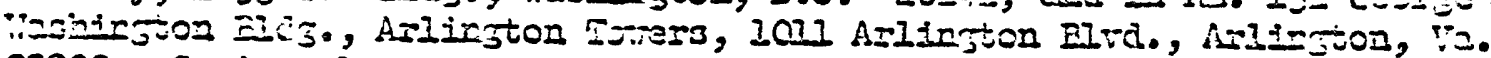

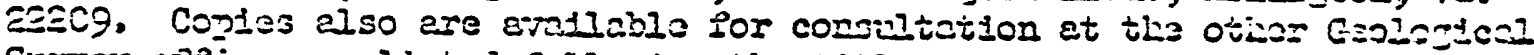

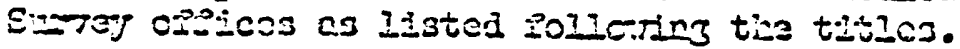

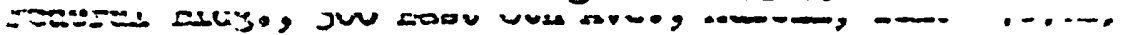

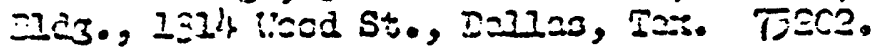

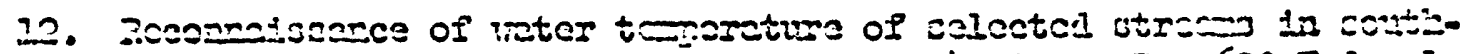

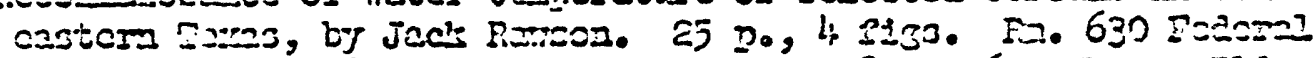

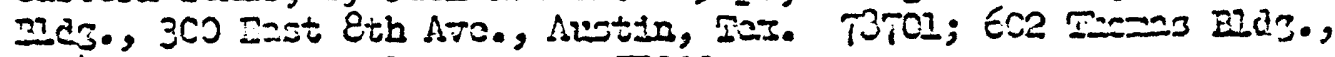
1324 licod St., Ialles, Tas. TJac2.

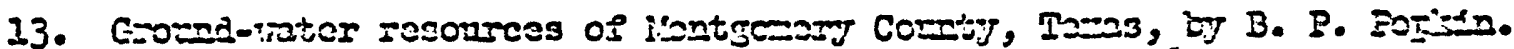

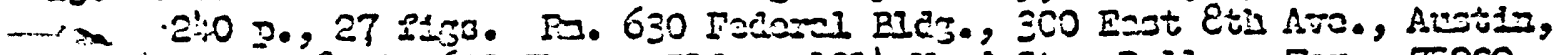

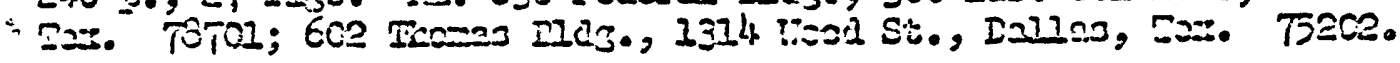

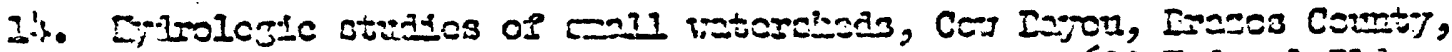

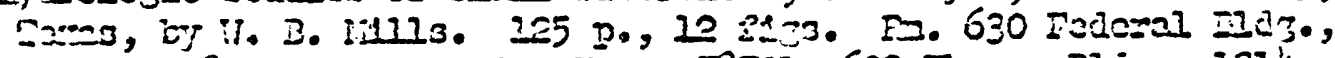

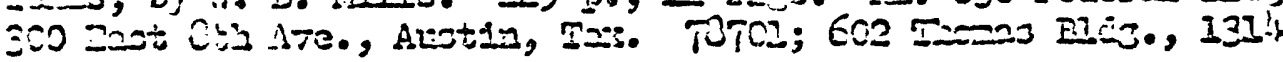
I:Ced St., Ealies, Taz. TOEC?.

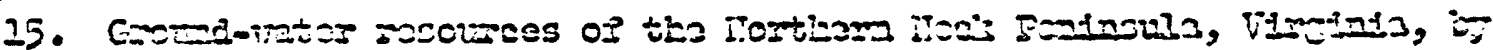

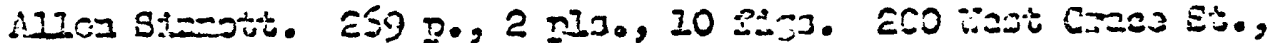

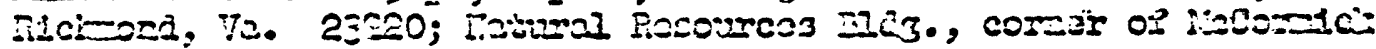

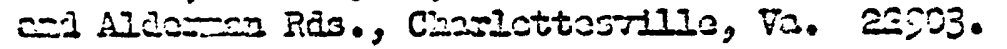

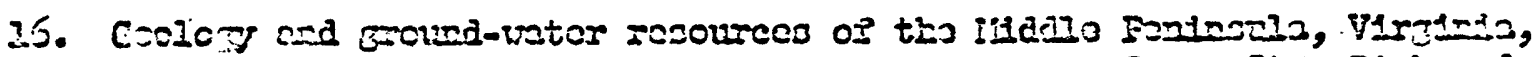

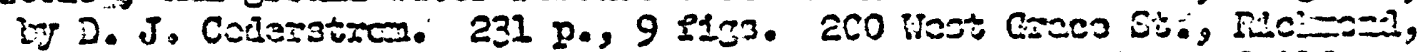

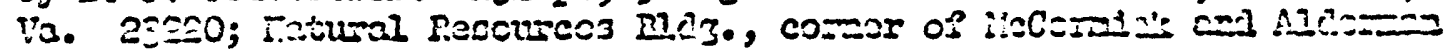

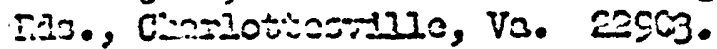


Abstract-

Intreduct1on and aclenorledgantan- T

GEOIOES 10

Pre-Gretaceous basement rock-10

Cretaceous System-Potomac Group- 13

Cretaceous to Tertiary system 14

Opper Gretaceous and Faleocene Serles-

Mattapont Format1on- 14

Tertlary Systex-17

Paleocene Serles-Aquis Frration- 17

Bocene Sertes-Hanjemoy and Chickahominy Formetions---- 19

HLcene Serlez-Chesapeake Groupm-n 22

Quaternary Sygtem-and 26

Fle1stocene Ser1es-Columbia Group 26

Quslity of Vater- 30

Optimum ground-water development_an 34

Arteslan reterm 34

Bracktsh vater-an 37

Recharge of brackish water strata- 38

Artesian water Ifots and bydrologic concepts-......... 40

Shallow water-C.- 44

I083 of vellg 49

Bconomic dita- 49

Casoline County- 50

Geologs 52 
Water bearing Formations-

Quality of water-a

Essex County-

Geology-

Water bearing formations-

Quality of water103

Middlesex County-

121

Geology--1

122

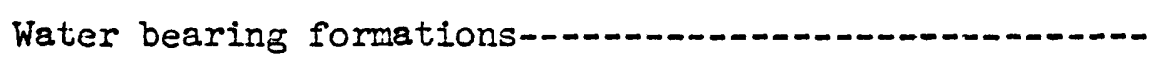

126

Quality of water--...-.-.

King and Queen County-1.-

Geology-_-1

Water bearing formations-

Quality of water.

Gloucester County-

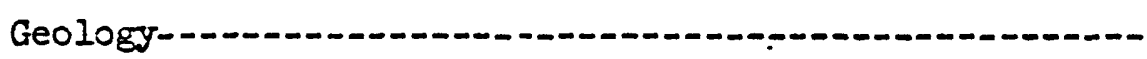

Water bearing formations-1-

Quality of water-

Mathews County210

Geology-1-20

Water bearing formations214

Quality of water-a 216

Bibliography229 
Noturet

Intraduetion and expouladgenate

aeolocer

Banamat sook

Gretecous Syotem-Potome Group

Contaceon to Iortingy Syetem

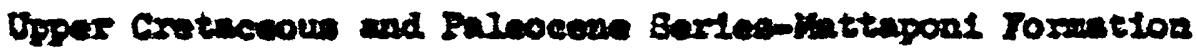

Paleoear Sarten-kgute Jormetion

Tertiaxy synten

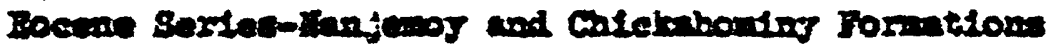

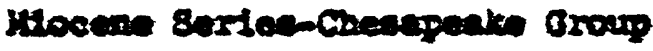

Opatamary Syatem

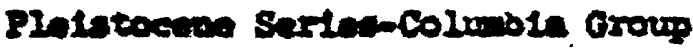

gunsty of hetex

Irteatad yetex

Erackels vatar

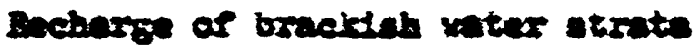

Artealun vater rlohte and prdrologle conespto

andlow vatax

lom ar velle

Loosonde inta

Carolin Coutaty

Coology

Ground vatar resources 


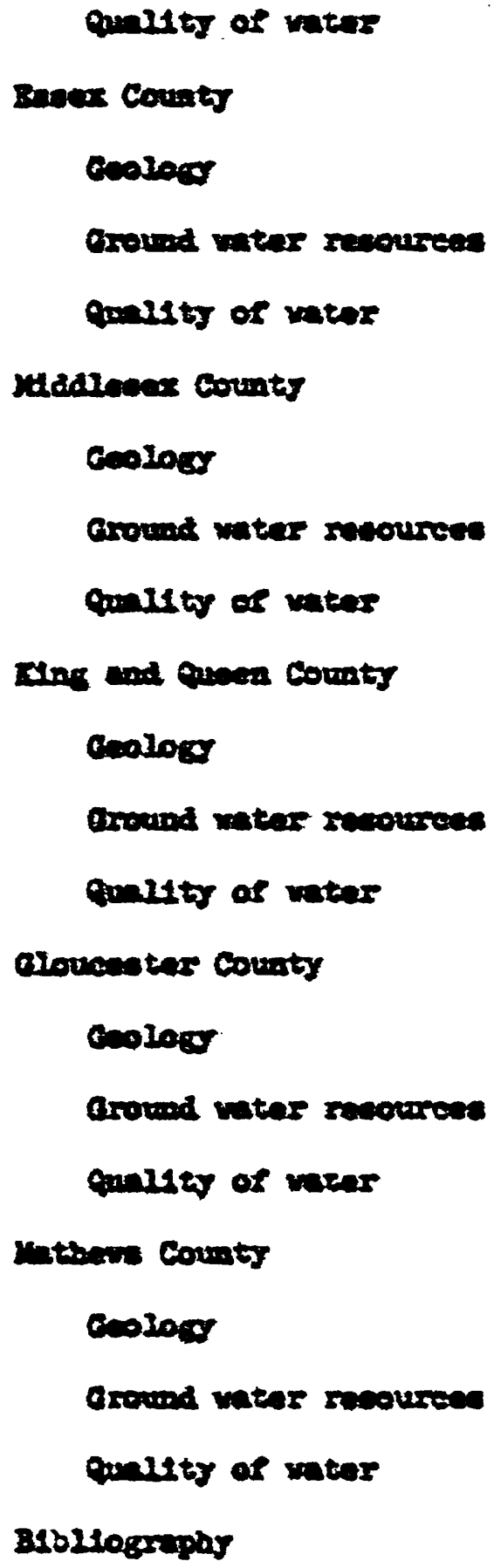




\section{Iuntartion}

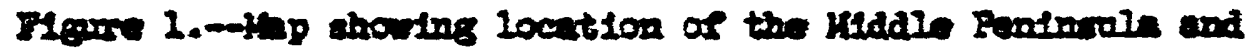

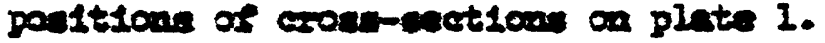

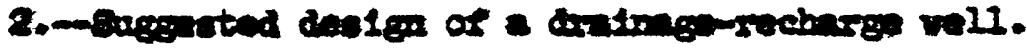

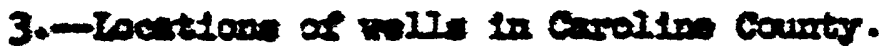

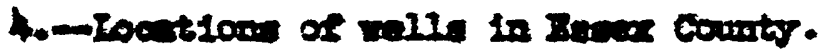

5.-location of molle in Madalenex county.

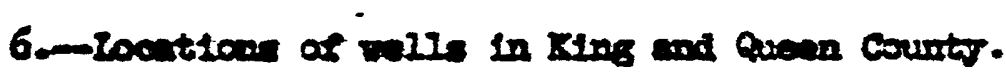

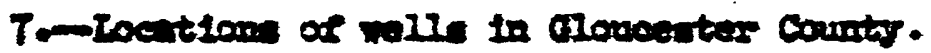

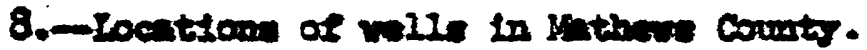

\section{Finte}

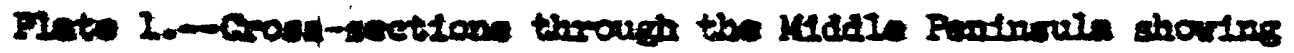
enolow. 


\section{2ubles}

1. Becost of vall in Cxolin counts $f$

2. Iog os vile is crolis county

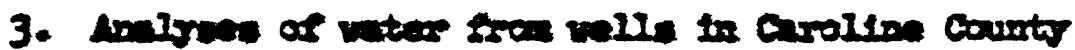

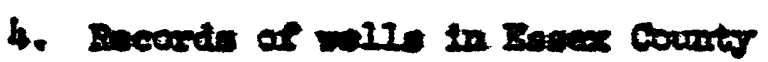

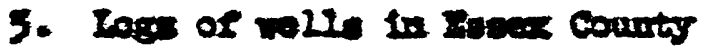

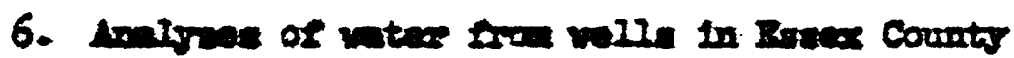

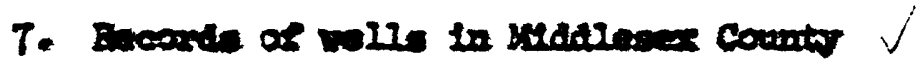

8. Lop of will is Matilener couts

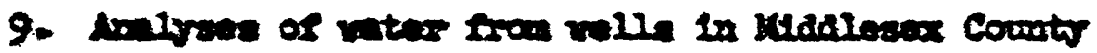

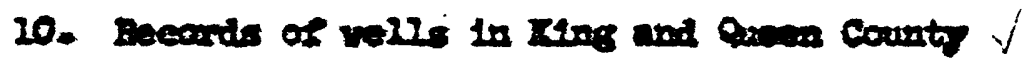

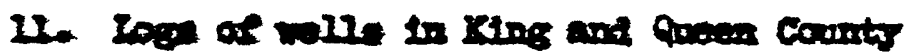

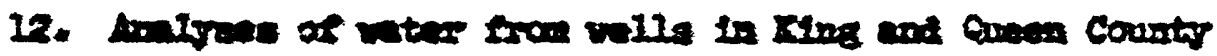

13. Bucouts of welle in Gloucoster County

14. Ioge welle in Glovecuter Conits

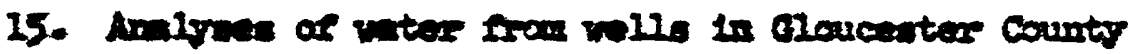

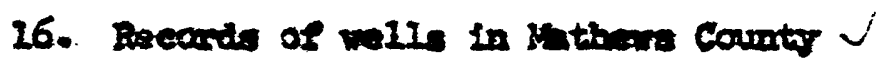

17. Loge a walls in Hethem count

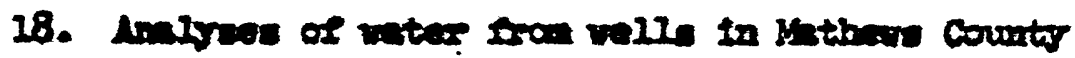




\section{Geoloes and Ground-Weter Resourees of the Medie Pentnoula, Viretnis}

Bip

D. I. Cédestarean

\section{Abrtaset}

The Midde Peninnule of eartern Virginie is part of the Coagtal Flain province. It extends exen the Fall Itne to Cheanpeeke Bay and Iles betreen the Rappabannock FIver on the north and York and Muttapont Rivers on the south. Curoline, Becex, Mtddlesex, King and crean, Gioucanter and Kathew Counties aro included in the report. Fleld work in the aree we carpled out by several indiriduals and

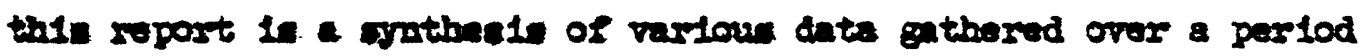
of time. Beconds of inseg yteld vello drilied in the lact several years do much to update the report. The geology lo based largely an the wrter'a interpretation of drillers' $10 \mathrm{gs}$ and well records. Cauparinon with better controlled geologs to the north and south bas been helprul in arsiving at som degree of accuracy in drawing of etrutigraphic boundarlos.

Tho area conilots largely of farme and roodlands with scattered anell villages and a largo town. The largent tow unita are Eort Rooral, Itappahanoock, and Urbanna on the Rappahannock RIVer. Boullng Creon lies Inland and buthow lies off Chesapeake Bey. Namufucturing is not greatiy lmportant in the area and is in good part besed on lumber producte. Sport and cownerffel sishing 
are important locelly. Farm crope range videly in economis value froin cownty to coumty. Couneretal production of flowers and bulbe,

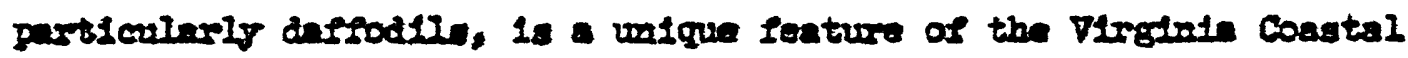

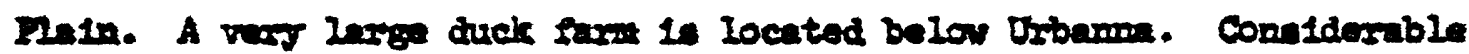

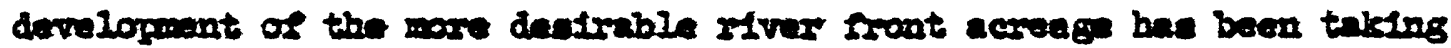
plea in the inst decade, In jart as "suburbs" of Urbanom and

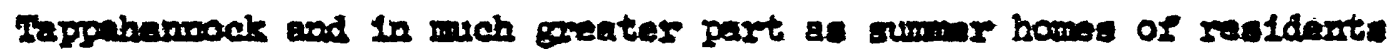

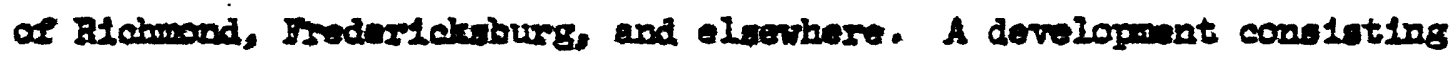

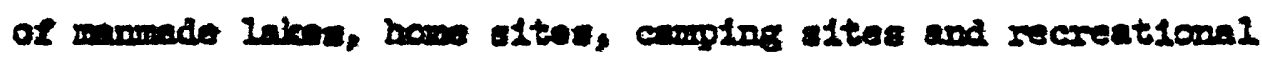
encilities is baing esteblishad in caroline county. A large militany

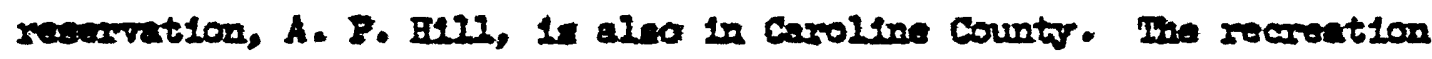

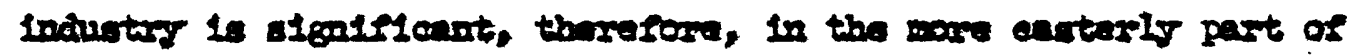
the vesale Pontnoule, and w121 probubly fnereace in inportance.

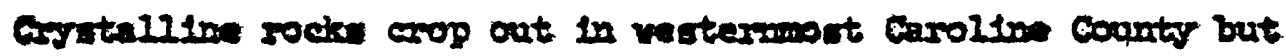

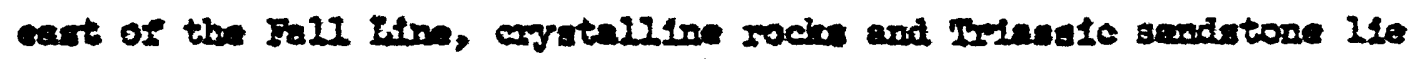

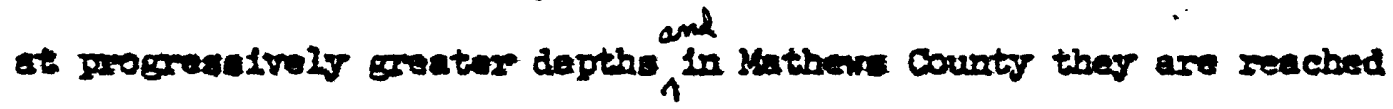
at 2,300 foet bencuth the cover of Courtal Flals sadinanta.

Onconsolidated sediment of the Potcume group of Iarly and Late arotacsoun age rest upon the becoment rock. Thes do not crop out in the aro but have been pemetrated by welle in cintral and cantarn orsolin countr. The deep well in Kathewn County penetrates the sull saction of Potome andinente. Theme the Fotomac saction may bout 900 feet thick and conntert of alternating and and ald beds. 


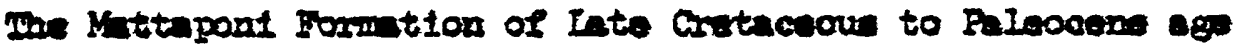

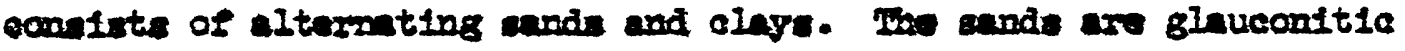
or glaucontte and and in wer pleces the elny aro highly colored.

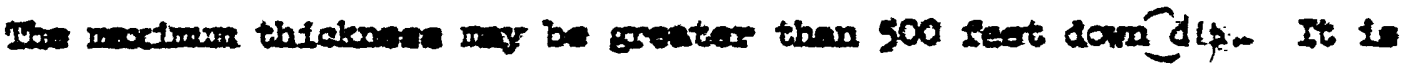

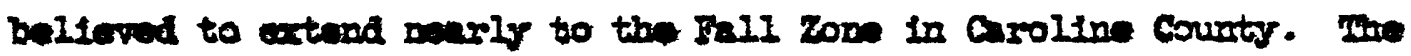

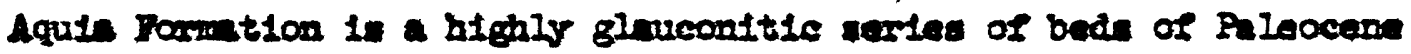
age. It is velI dervioped in the FeII Zone area but thine out dorade:-

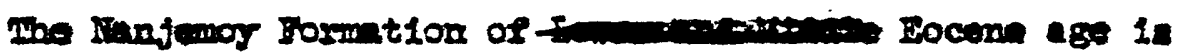
Fintively thin in the Fil zoos aro but thickens to about 100 lest entrinde. However, I1ke the Aquia, it aleo is truncented eastrand by

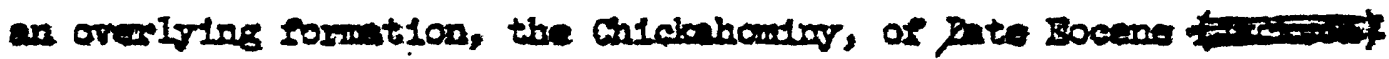

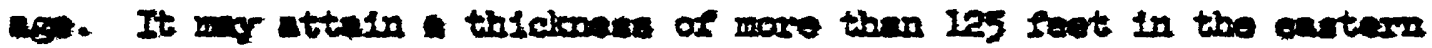
the

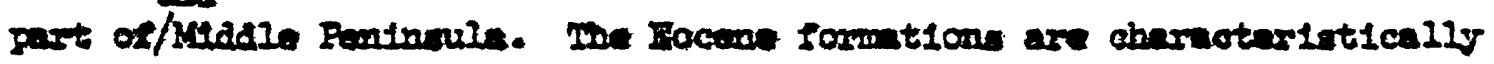
ginuconitic sand and mais. Thin bed of Ifmatone, comonly

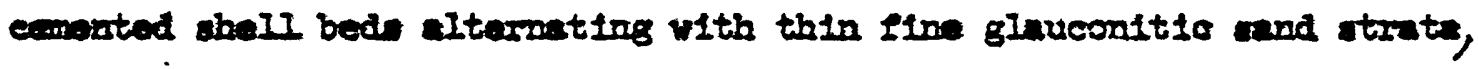

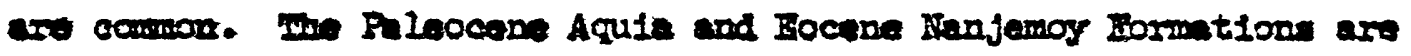
expoed along Rappabmock and Kattapont RIvere but the orerlying anicknoutry Formation is lonom ondy at dopth.

Whe Inte Gretaceous to Bocene beds are transected by the Chemepeake group of marly formetion of Mlocene age. In centrinl Curoline County the bese of the Mlocen $110 \mathrm{~s}$ about 100 feat above wa level but in the countles adjacent to the bey the Mlocene may axtiend to more than 400 feet belor sea level. 


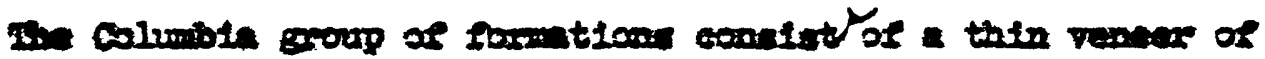
most of

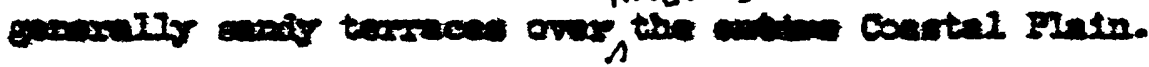

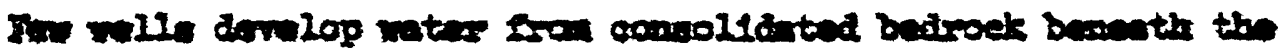

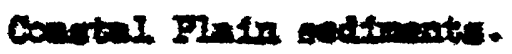

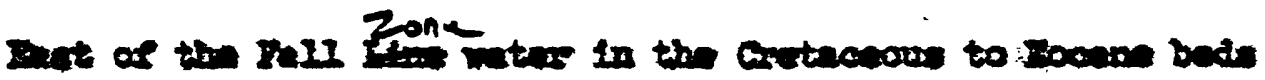

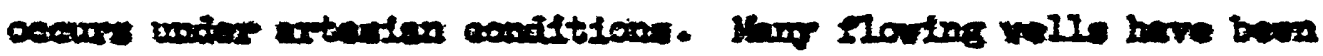

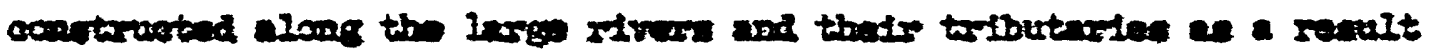

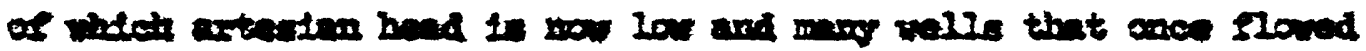

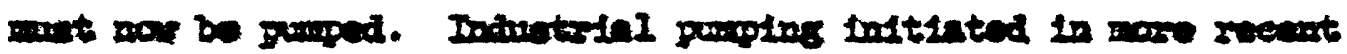

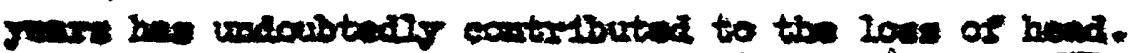

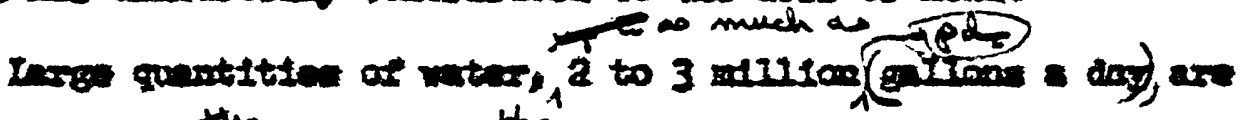

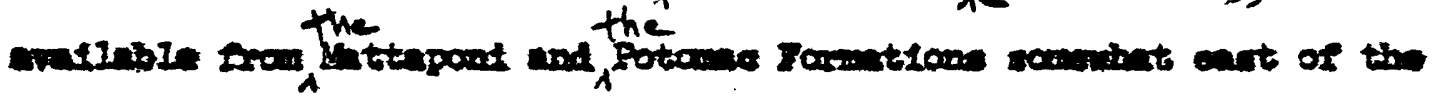

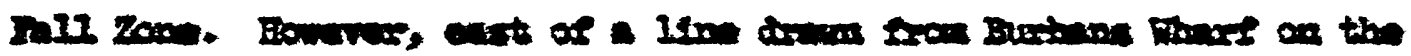

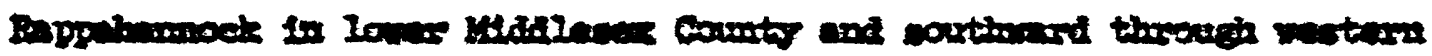

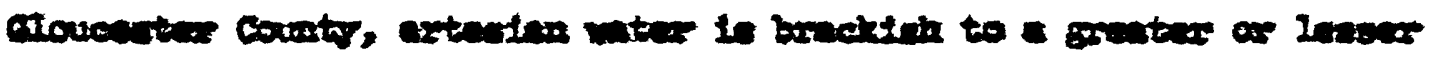
2000.

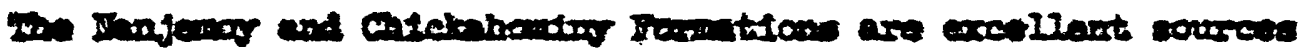

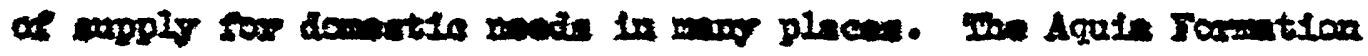

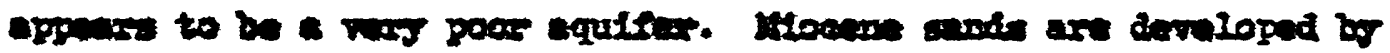

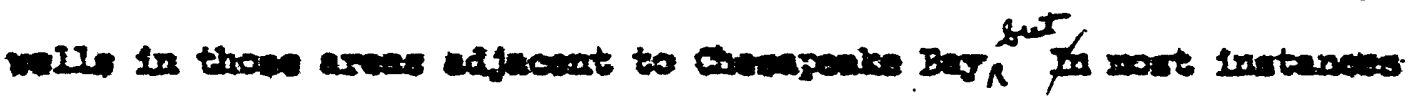

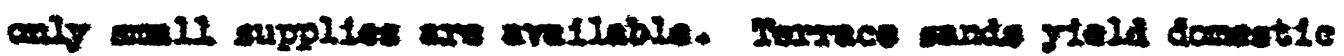

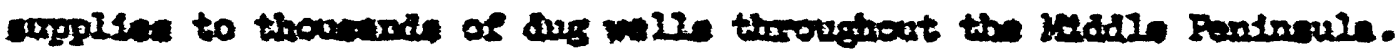

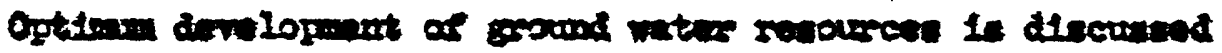

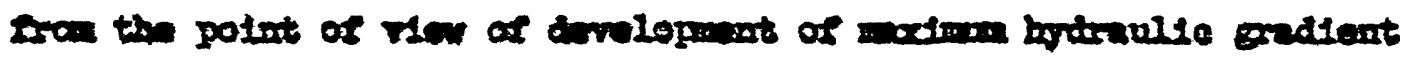
1 


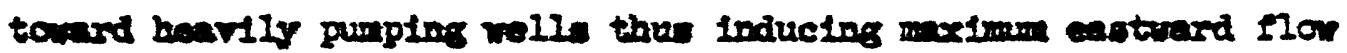

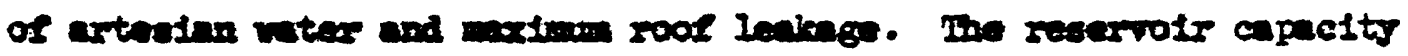
of Contal Plats eadisante can be utllined in mas places by

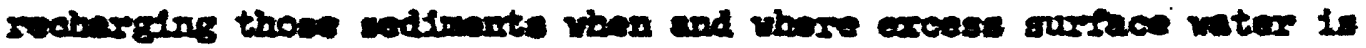

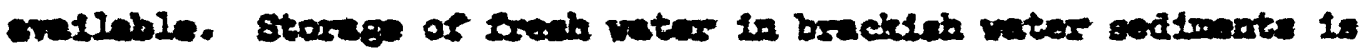
also poedble. Becovery of the great nolme of reabnre reedived

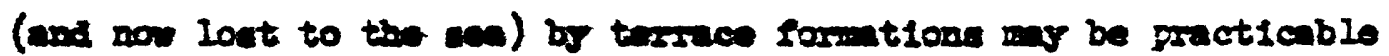

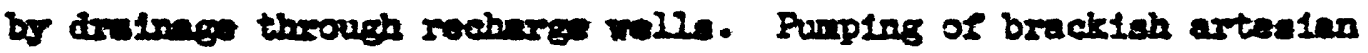

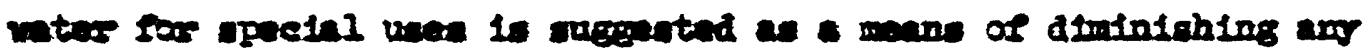
tendenes of the enlt vater eront to move upalp.

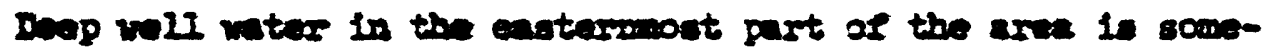

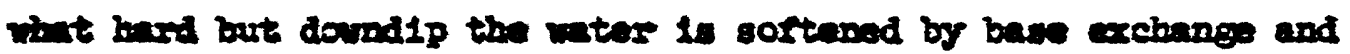

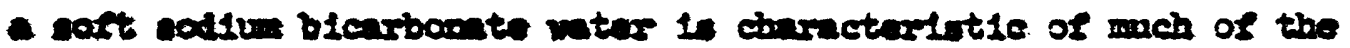

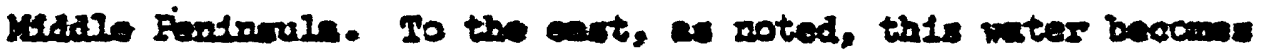

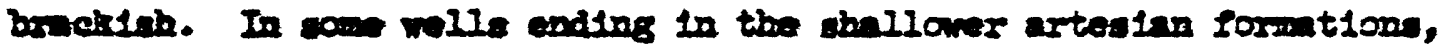
water is bardar than mifort be otborrito expected, thus suggesting

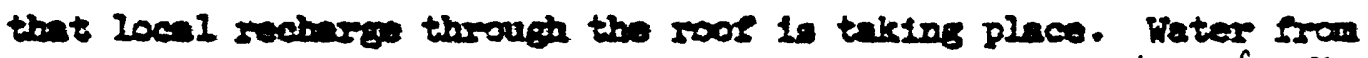

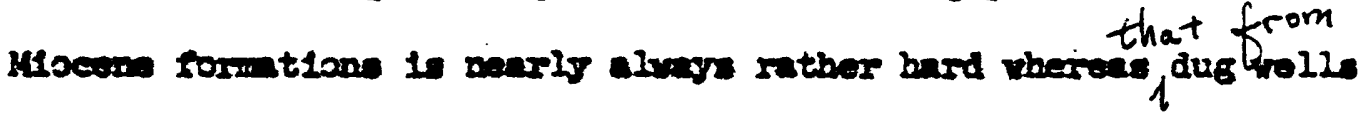
onding in ternes sand is nort.

Curolsw County I1ee along the InII zone. Bedrock crops out In the restermeont part of the county. Deep sande are fine in the contral area, as at Borling Green and sow difficulty has been experlenced in developing ingers supplies. In the eaters gart of the count contal Plain sand are thick and conditions are farosable for developing Iarge supplies. Port Royel and Bowling Green bare manlalpi wil wator supplies ond A. P. BIII MIlitary Rewervation I0 rupplied by welle. 


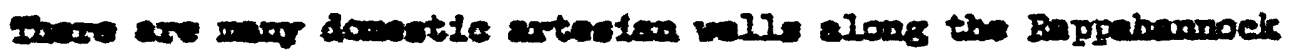

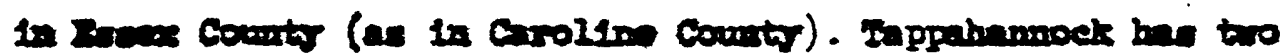

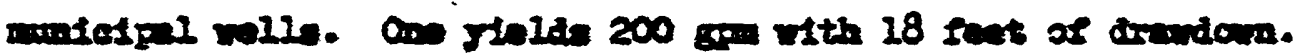

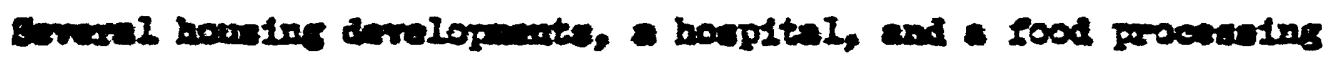

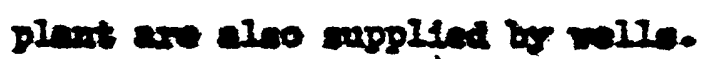
wells

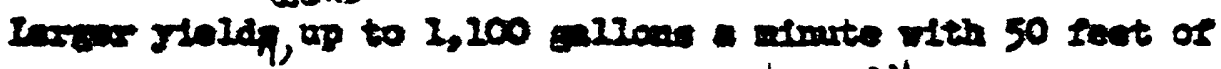

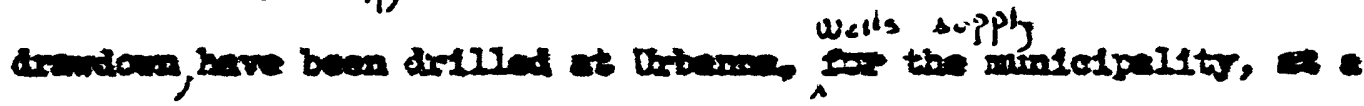

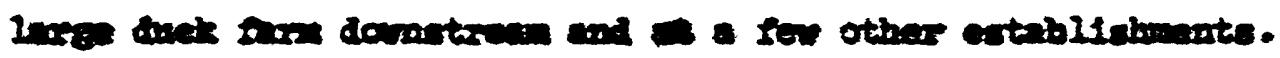

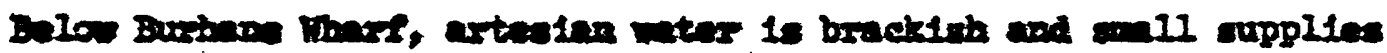
shallow water talkle weils ending in

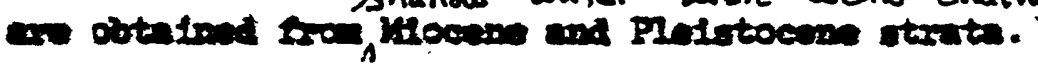

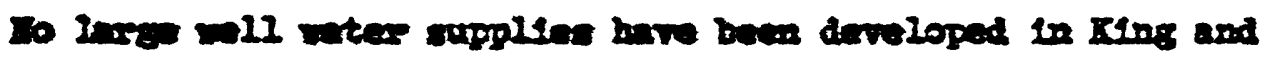

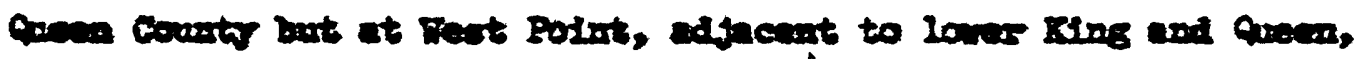

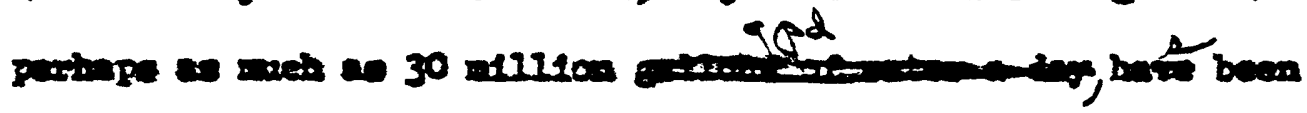
croloped sor an enduntarind apply.

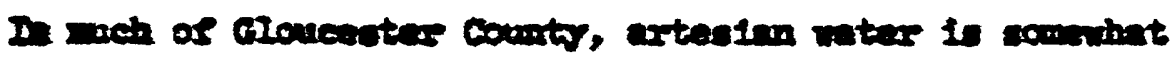

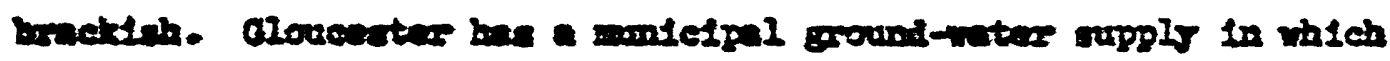

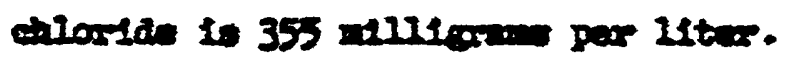

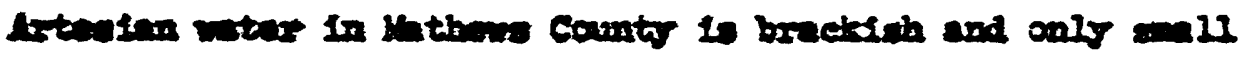

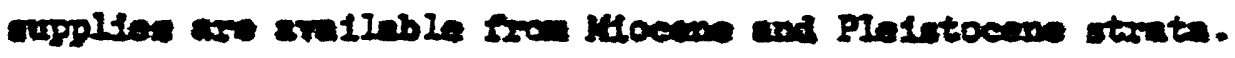


Introduction and Acknowledgments

The purpose of this report is to make available information on the ground-water supplies in the Middle Peninsula. The data presented pertain largely to the depths of wells and the strata from which water is obtained, the quantities available and the chemical quality of the water. Where ground water is limited in quantity or saline in chemical character, effort is made to show the practicability of ameliorating potential shortages by artificial recharge.

The Investigation of the ground-water resources of the Middle Peninsula in Virginia was begun in the early $1940^{\prime}$ s as a cooperative project of the Division of Geology of the Virginia Department of Conservation and Economic Development and the U.S. Geological Survey. Work continued intermittently until 1957 and was completed in 1968. 
Work was performed infilally under direction of the late 0. I Meinzer, geologlat-In-charge of the Ground Water Branch, U.8. Ceological Survey and aubsequently under the late A. H. Sayre who succeeded 0. E. Meinzer. The work in 1900 was carrled out under the general direction of G. E. Ferguson, Reglonal Huarologist, AtIantic Coast Rection, and Wyatt Gambrell, Distrlet Chief, of the U.S. Geological Survey. Virginla cooperating officials during the earlier years were the late Arthur Bevan and the late H1IIIam McG111, State Ceologists. In 1968, James I. Calver, State Geologist and the Division of Commlsaloner of Kineral Resources was the cooperating official.

some fleld work in the Middle Peninsula was accomplished by the writer during World War II although at that time the greater amount of his work was carrled. Out in the York-James Feninsula. Additional data were collected in the Middle Peninsula counties in succeeding years by Allen Sinnott, who succeeded the writer as geologist-in-charge of cooperative ground water investigations in Virginia, and by his assistant, G. Chase Tibbitts, Ir. The lield ras brlefly visited agein by the writer in 1968 at which time a number of slgnificant wells were located and additional water camples vere collected. 


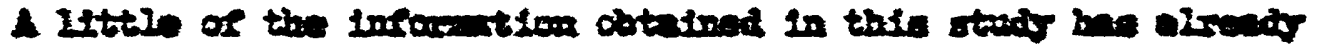

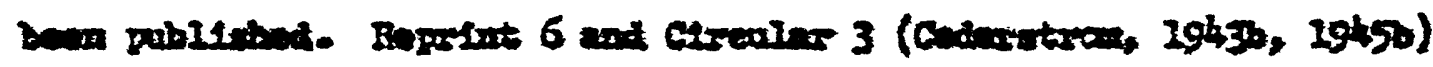

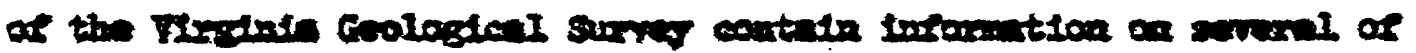

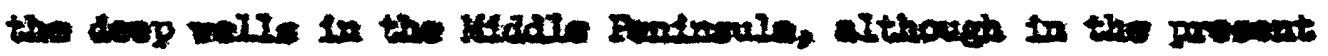

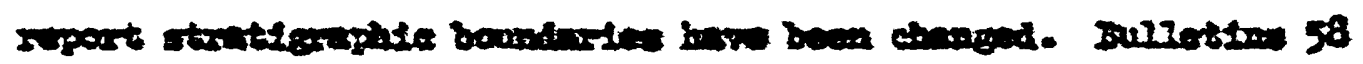

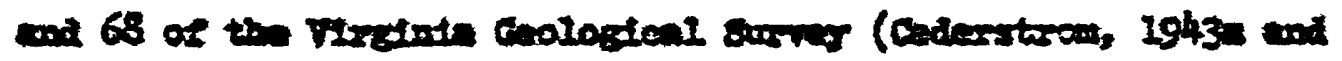

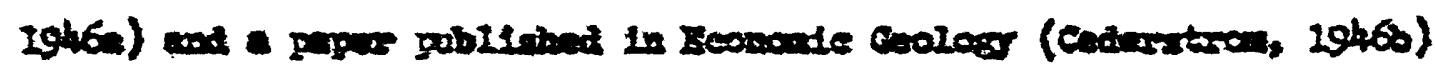

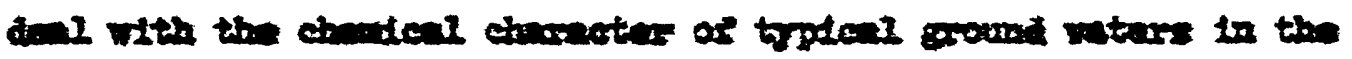

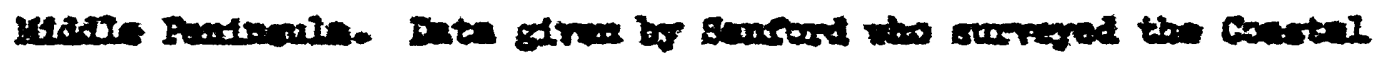

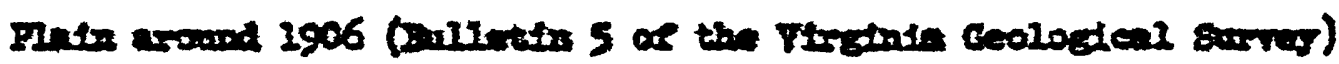
have

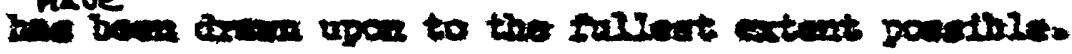

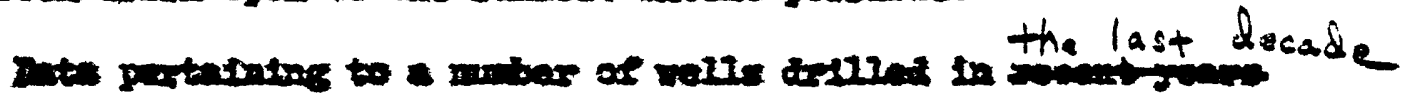

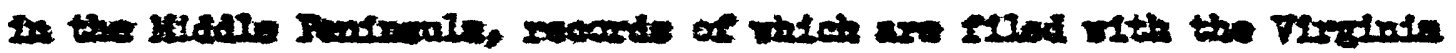

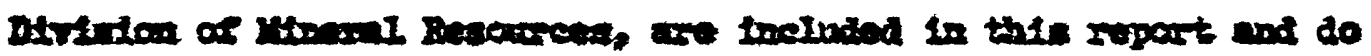

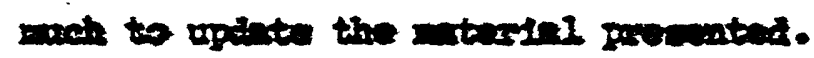

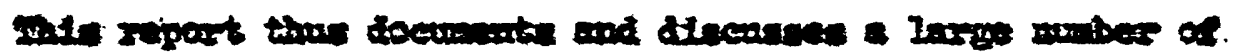

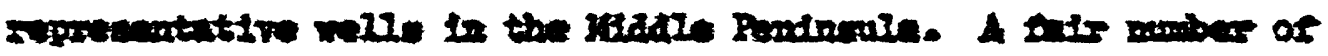

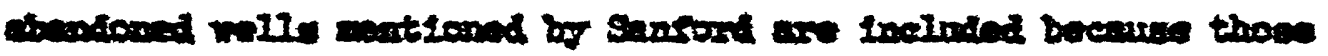

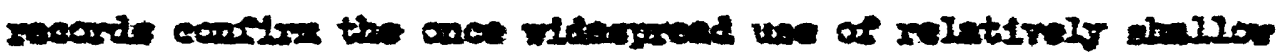

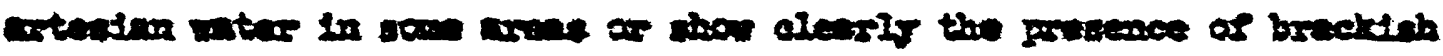

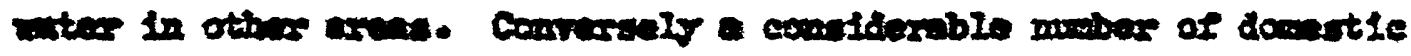

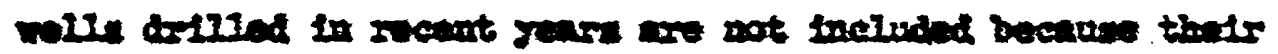

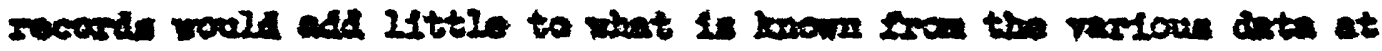
mad. 


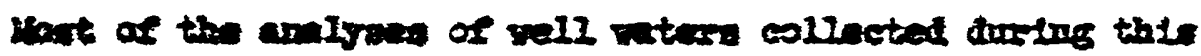

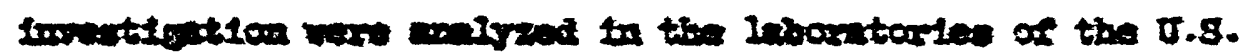

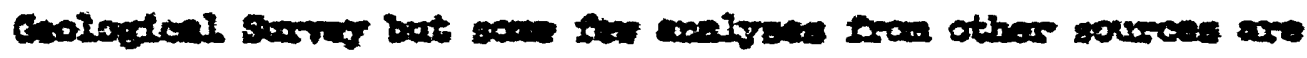
ateo snowion.

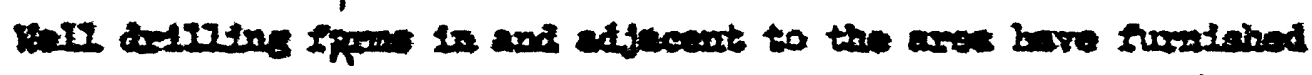

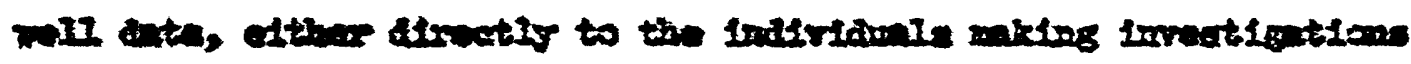

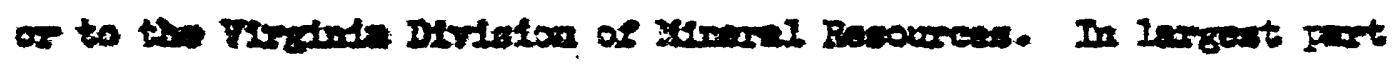

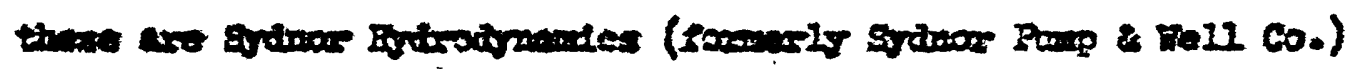

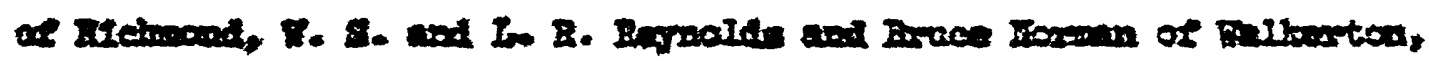

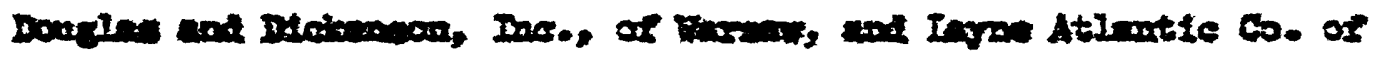

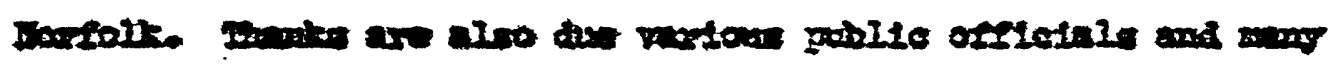

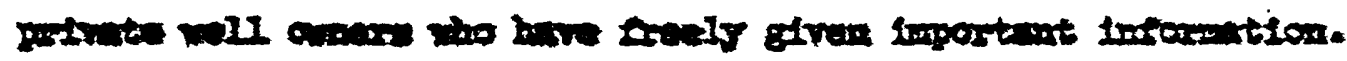


The area included in the Middie Peninsula (fig. I) is underlain by unconsolidated beds that dip gently seaward and rest upon consolidated bedrock, elther Trlassic sandstones and shales or granitic rocks. The unconsolidated sediments are of Cretaceous, Paleocene, Eocene, Miocéne and Plelstocene age, and consist of a serles of alternating sand, clay and marl beds (pl. I). At Guinea and Ruther Glen, in west-central Caroline County, just east of the Fall Iine, unconsolidated sediments are thin and bedrock bas been reached in several wells. West of the Fall Iine the Corstal Plain 1 sediments have been removed by erosion and bedrock is exposed at the surface but east of the Fall Iine the basement rock Iles at progressively greater depths and near Mathews the thickess of unconsolidated sediments is 2,300 feet.

\section{Pre-Cretaceous Basement Rock}

Triassic System

Bedrock is exposed at the surface in westernmost Caroline County and has been reached by several wells in the west-central part of the county (table I): It is of particular interest to note that at Bowling Green and Moss Neck (wells 16 and 4l, table 2) bedrock is Trlassic sandstone rather than ranitic rock. A wedge of Triassic strata is shown on the Geologic Map of Virginia near Doswell, Hanover County, 5 miles south of Ruther Glen. Presumably, infaulted Triassic beds may contimue northward from there as a narrow band. However, "rock" penetrated at a depth of 
1,284 feet at West Point; immediately adjacent to lower King and queen County, is here tentatively assigned to the Triassic. It cannot be assumed that the Triassic underlies most of the Midale Feninsula. More Iilkely, Triassic beds occur as a series of somewhat narrow north-south trending bands between irregular areas of crystalline rocks.

\section{Water-Bearing Properties}

Consolidated rocks ordinarlly yield much smaller quantities of water to wells than those developed in unconsolidated Coastal Plain sediments and will be dealt with briefly here. The average yield of domestic wells in elther grantic rocks or sandstones is in the nature of a few gallons a minute. It has been found, however, that in Industrialized areas like Richmond, where a maximum effort has been made to develop water from hard rock, some very high yields have been obtained. As much as 300 spm per well has been obtained from deep wells in granitic rock in the Richmond area (Sanford, 1913, p. 85) where a considerable drawdown has been used, perhaps in excess of 200 feet of drawdown. Several out and out fallures are also reported.

In resternmost Caroline County Coastal Plain sediments are thin or absent altogether. Here it may be desirable, when more than minimum quantities of water are needed, to drill at several somewhat widely spaced locations in an attempt to develop water in some 
quantity. Developers should avail themselves, of technical advice in order that wells be located in what appears to be the more favorable sites. Where multiple wells 400 feet deep or more are drilled, an average yield per well of up to $90 \mathrm{ggm}$ might be obtained from granitic rocks and up to $150 \mathrm{gpm}$ from sandstones.

\section{Cretaceous System - Potomac Group

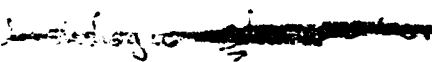

Sedinents of the Potomac Group of Early and Late Cretaceous age crop out in the Richmond area south of the Middle Peninsula and in the Fredericksburg area to the north. These sediments consist of alternating lenticular clay and arkosic sand deposits of continental origin. Farther to the east the Potomac sediments are buried beneath a cover of younger sediments and in the Middle Peninsula area have been reached by very few wells. At West Point, adjacent to lower King and queen County, it is believed that Potomac beds were reached at a depth of 800 feet.

\section{Water-Bearing properties}

Wells developed in Potomac sedinents near the Fall Zone have not been conspicuously successful in yielding large quantities of water but some miles east of the Fall Zone in the York-James Peninsula (Cederstrom, 1957) and south of James River (Cederstrom, 1945) the Potomac beds have proved to be excellent aquifers. In the Middle Peninsula the few wells that develop large quantities of water, as at Tappahanncck, Urbanna, and Walkerton, end in the overlying Mattaponi Formation and little can be said of theis potential in the area. However, at West Point a well drilled in in 13. . P. . .....sis 


\section{Tabout 700 gprol}

1961 developed a million gallons of water a day with fis feet of drawdown from Potomac beds. It is presumed that Potomac strata of similar water-bearing potential underlie much of the Middle Peninsula from which comparable quantities of water might be obtained from deep wells. However, in most of Gloucester, all of Mathews and in lower Middlesex County, water from Potomac beds is brackish and not suitable for some uses. Near the Fall Iine Potomac beds are thin and may pinch out entirely.

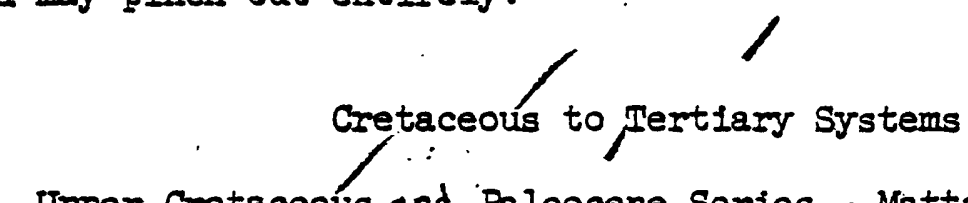

Upper Cretaceous and Paleocene Series - Mattaponi Formation .

The Mattaponi Formation was established in eastern Virginia on the basis of lithology and microffossil study of well cuttings from wells at Colonial Beach and Washington's Birthplace (Cederstrom, 1957, p. 17-21), both of which are located at about ilo miles north of the Middle Peninsula. The beds are described as somewhat glauconitic clays and subordinate sands in the upper gorton and bighly colored or mottled clays and subordinate sands in the lower portion. The highly colored clays may or may not be glauconitic.

Beds of similar appearance have been logged as far west as Bowling Green. It was noted (p. 20) in the report cited in the preceding paragraph that Foraminffera similar to those found at a depth of 600 feet at Kilmarnock were found in cuttings from the Moss Neck Manor well (4I, fable 2 ), almost as far west as Bowling Green. 
At and Bowling Green the Mattapons Formation, as tertatively lantifled by the prewence of nottled claya but including

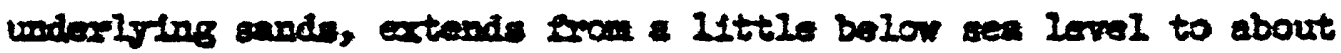
125 seat beicm sea level. Bedrock at Bowling Creen is at about 260 10wt belon sen level. Adopting this interprotation, a thin section of Potone bed underilte the rattapont Formation in sestern Carolibe

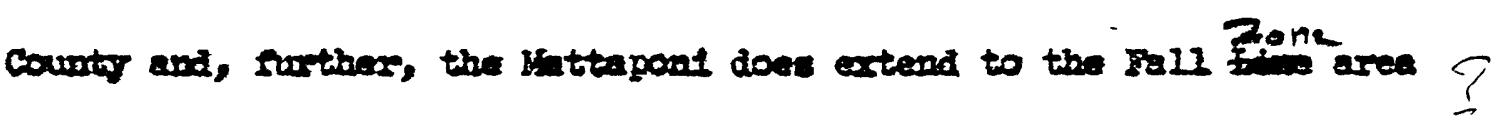
but at rach a dopth that it should not be expoeted to be exposed at

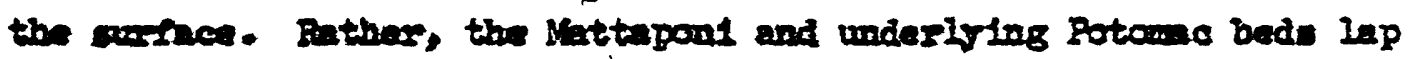
wy agntert the slope of the betrock surface and are truncated by

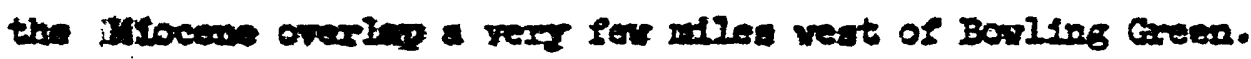

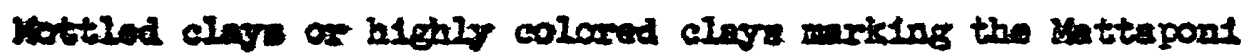
Fosution bave bean reparted in loge of welle in the Bouling Gasen ares, as already stated, at Felleation and Hest Bolnt along the

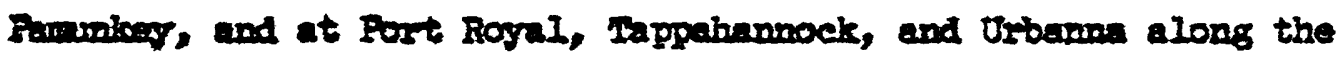

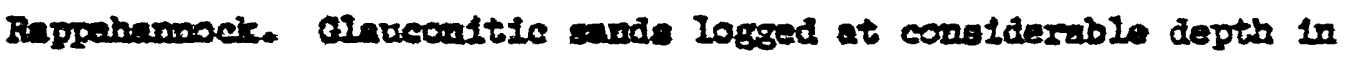

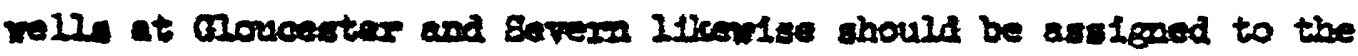
Nattapons Foumation rather than to the Fotowne grours.

Dilllese' loge at hand are not datalled enough to permit a seacombio accurete atratigrephle separation of the Mattapont Focmation fran the overlylug and underiving forwations in the wore eaterly part of the asea. At Vest Polat mottled clays extend to about 600 seet belon sen 1evel. If 


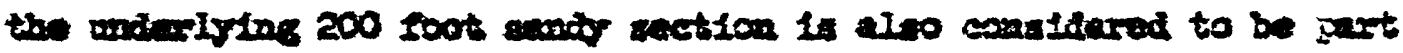
of the Untropons, then thet sasmation there is about 640 seet thick.

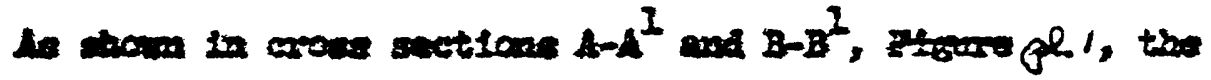

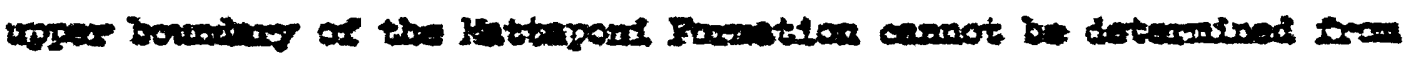

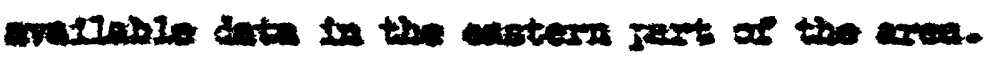

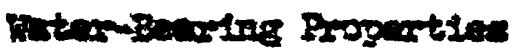

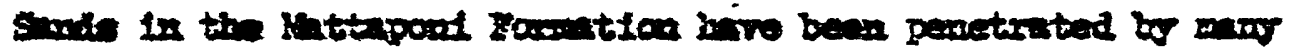

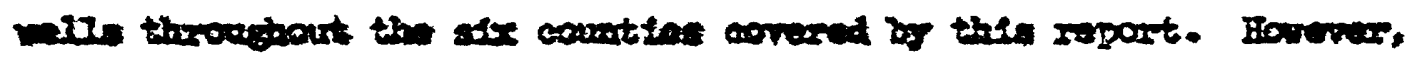

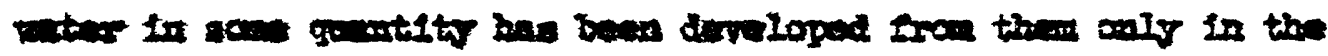

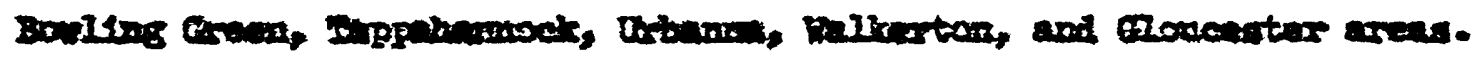

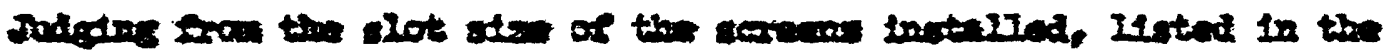

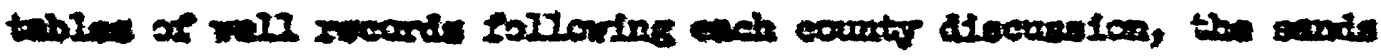

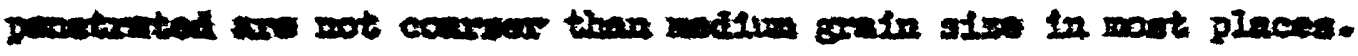

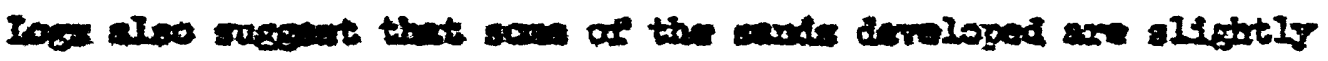
einger.

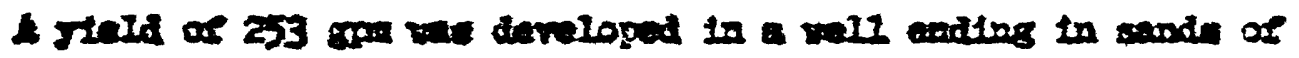

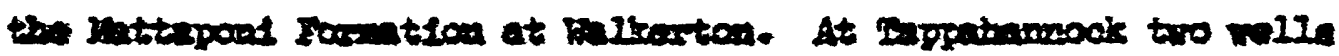

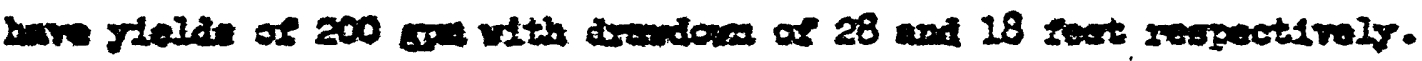

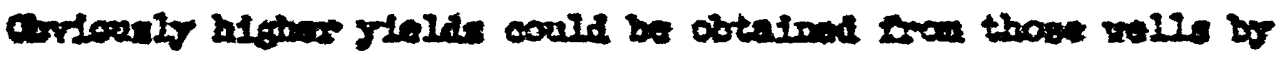

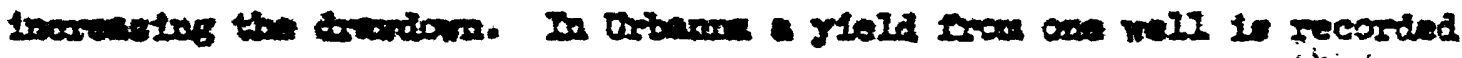

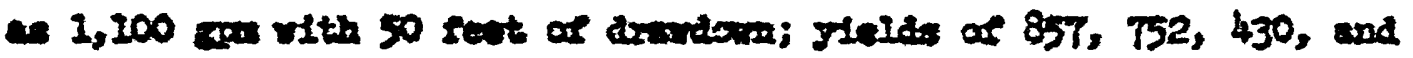

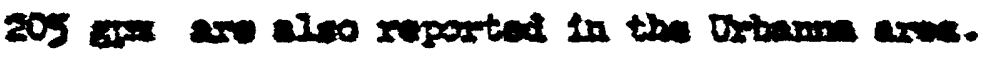

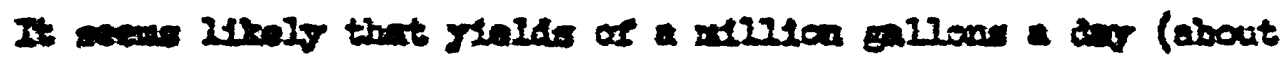

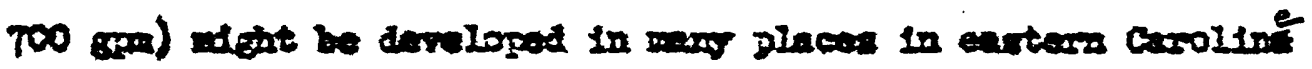


County, in all of King and Queen and Essex Counties, and the westerly portions of Gloucester and Middlesex Counties from wells no deeper than 600 leet by Installing larger diameter casings (to accommodate large turibine columns) and ample screen, and by utilizing 50 feet or more of the avallable drawdown. In central Caroline county, the section of coastal Plain formations is limited and good waterbearing sands are few. In eastern Gloucester and Middlesex Counties and in all of Mathews County, Mattaponi aquifers yield brackish water.

It seems Iikely that the zone of coarse basal sands of the PDTDKT reached by any wells east of Port Royal. Hence, even larger quantities of water may be available from properly screened and developed wells along mach of the Rappahannock and, of course, in King William and western Gloucester Counties along the York and Mattaponi Rivers from weIls about 200 leet deeper than the present wells there. Water from such deeper wells would not be expected to have a chloride content appreciably higher than that characteristic of water from existing wells.

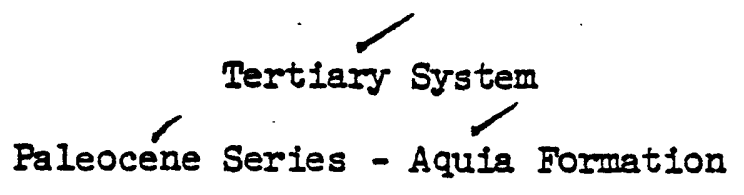

Bennett and Collins (1952) showed that the Brightseat Formation in Maryland which underlies the Aquia is of Paleocene age. Ioeblich and Tappan (1957 a,b) determined that the overlying typical Aquia 
itself is of Paleocene age.

Whether or not the Brightseat Formation is in fact equivalent to the upper part of the Mattaponi Formation is yet to be established. To avoid lengthy discussion that would not be fruitful insofar as this paper is concerned, the Virginia pre-Eocene section will be referred to simply, in descending order, as the Paleocene Aquia Formation, as known from micropossils at Aquia Creek (Cushman, 1944), and the Mattaponi Formation of Paleocene to Iate Cretaceous age. 
The Aquia Frrmation, as defined at Aquis Creels, appears to thin out eantward from the Fall Zowe as $1 \mathrm{t}$ does in the York-James Peninnula (Cederstrom, 1957, p. 2h) and may not be present east of Thppanmock. Doundip the uppar hundred feet or so of generally glauconttic pre-Hfoces sedirents become incresalngly sandy and contain sore and wore thin "rock" (ahell Iimestone) strata as the Aquis thing and the overlyting Manjenoy increases in thlckese. The lower wore warly beds in such sections probably represent the Aquis Formation.

\section{Wetor-Bearing Properties}

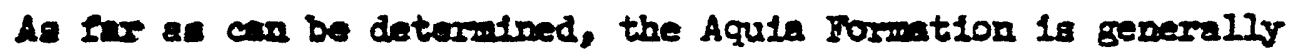
moly and a basal sand is reory poosly developed or absent. Hence, the Aquis appears to be essentinly nomrater-bearing in the Mldale Pantinala ares.

\section{Bocen Sertes - Hanjemos and Chlchahoutng Formattons}

the Banfemor Formation of Bocene age ulth its easily recognized

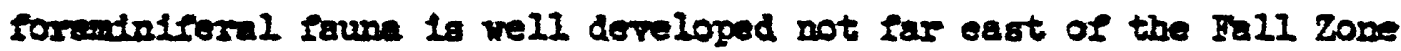
Dut appears to thin and vanteh eastward. As noted above, the typlcal underlying Aquis Porwation (Cusbun, 1944) also thins eastward (Cederstron, 1957, p1. 1). 


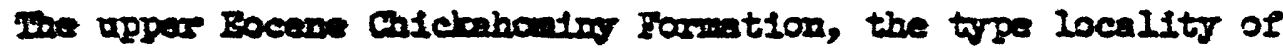
which is at Ioristom (Cummen and Cedexataran, 1945, and Cederstrom, 1957. p. 28), does not extend to the Fall zome. It Is present awout an far Iniand as Hert Point (adjacent to lower King and Oareen county) and Inpphamock and thidican to the east from a for feet to mowe than 100 foet. Merom analon 100 feet of bed penetrated In the Grapield well on the Badtern Shore (Simott and Tibbitts,

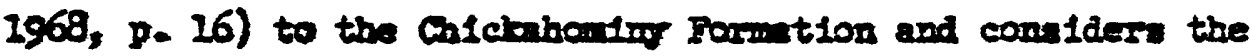
Fandenes to be aboent.

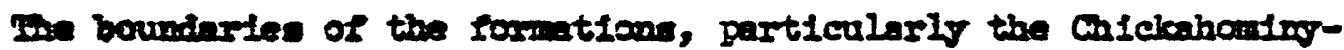
rinjeror-Aquis contacts, are tentative and based in large part on

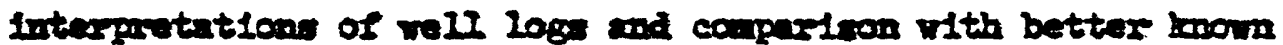

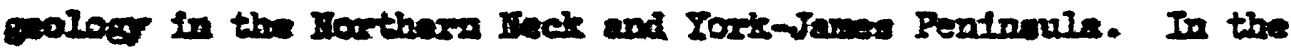

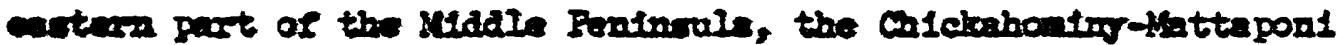
cortact canot bo detersind from erioting data.

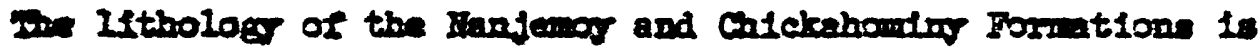
etding, as exp as wo be determinad frow well loge. Both formations 


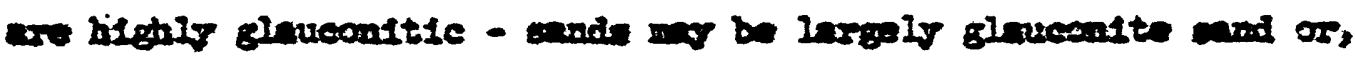

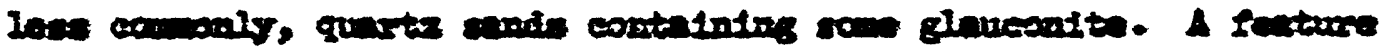

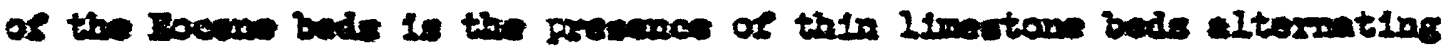

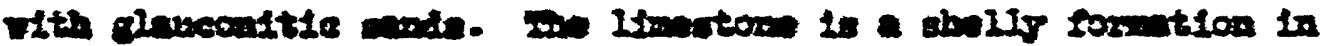

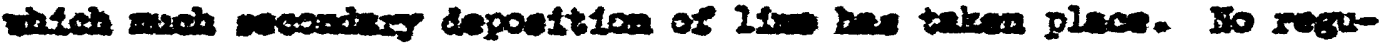

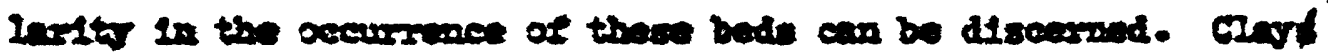

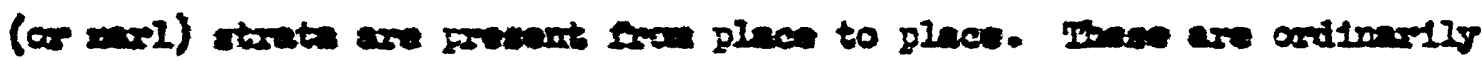
gownint elnweonftic.

Eutas buarias propartie TApríc

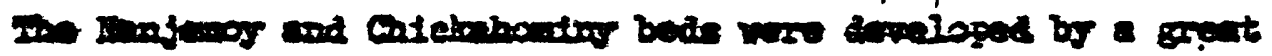

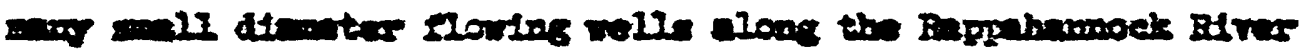

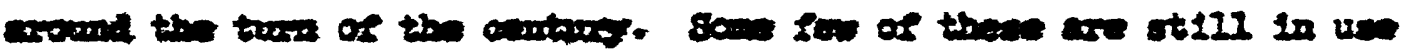

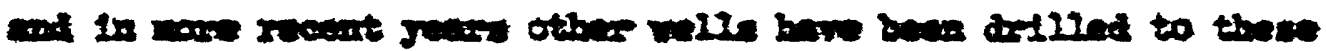

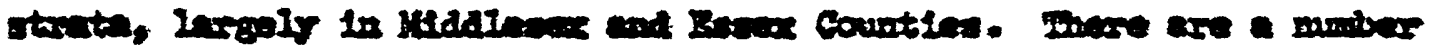
ar older will around ling asd fown in the count of that now

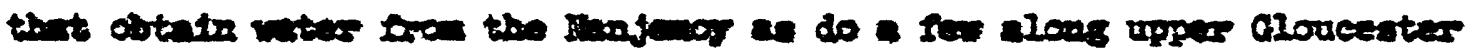

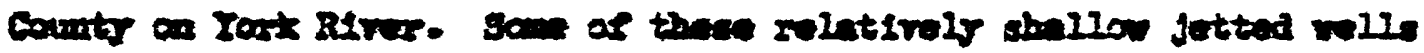

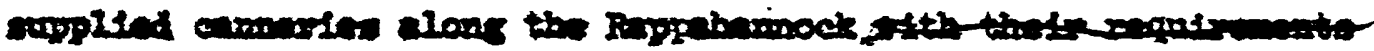

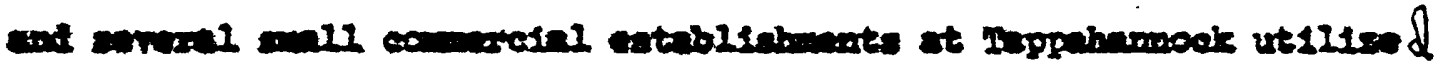

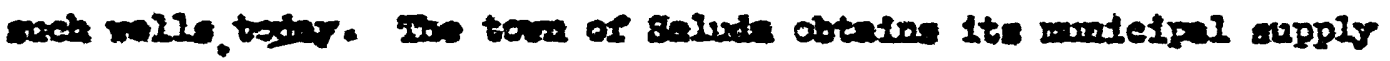

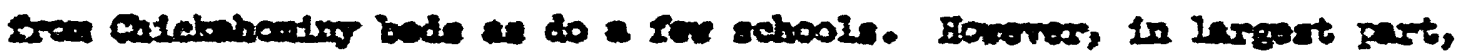

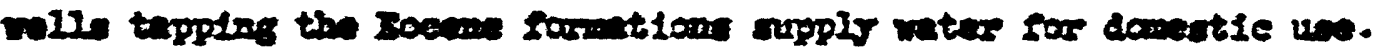




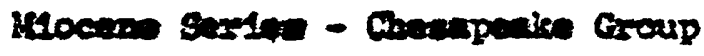 \\ Itthologis Cringeters}

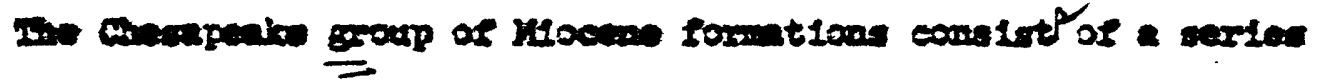

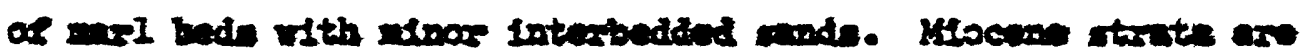

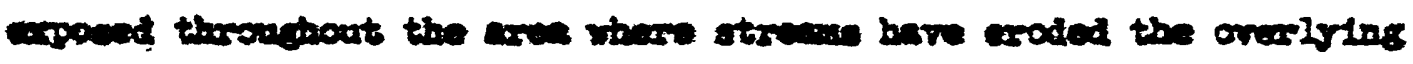

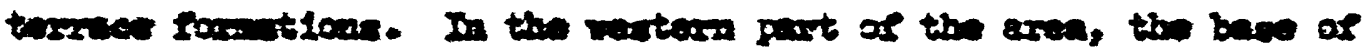




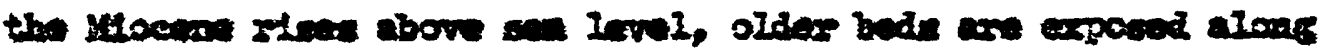

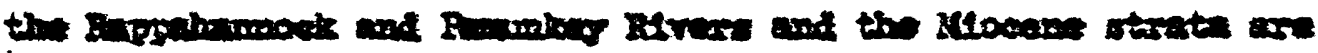

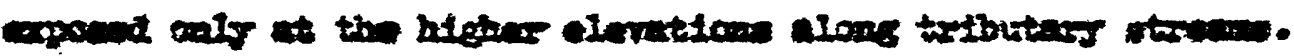

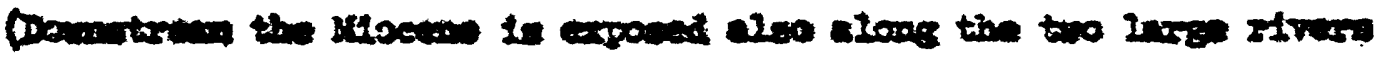
mentionat.)

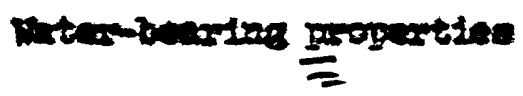

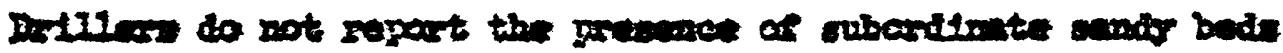

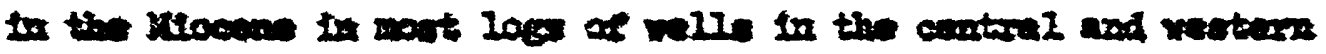

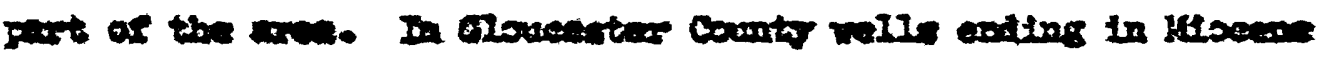

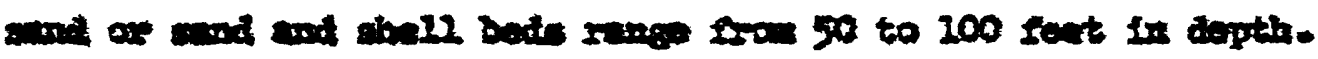

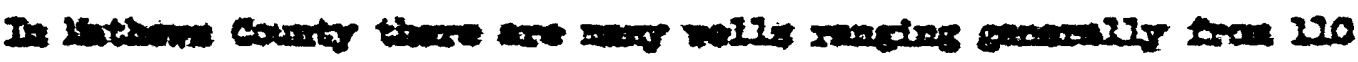

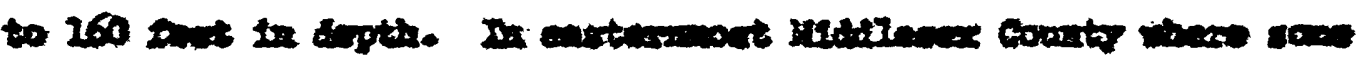

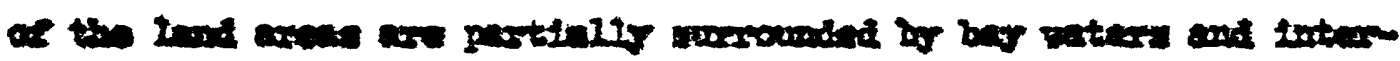

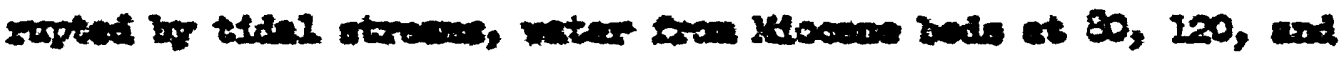

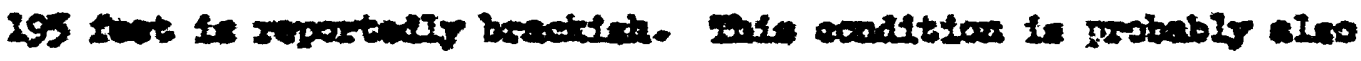

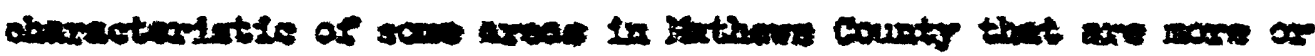

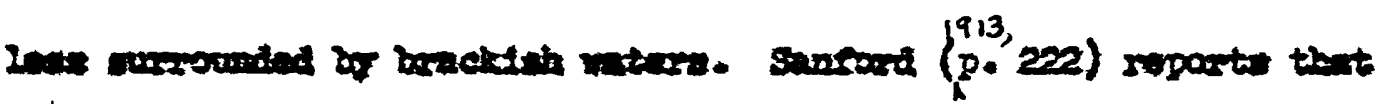

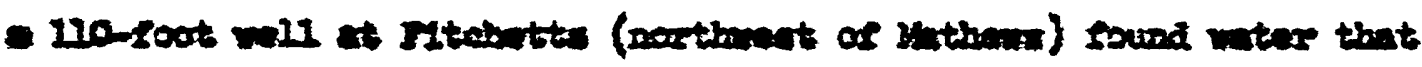
wat too acity to une.

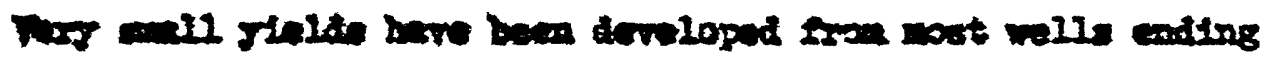

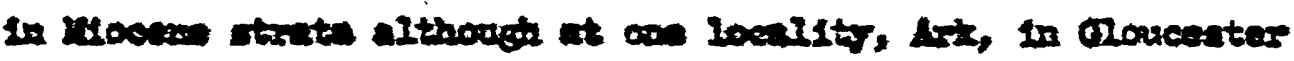

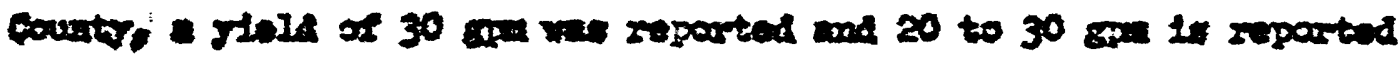

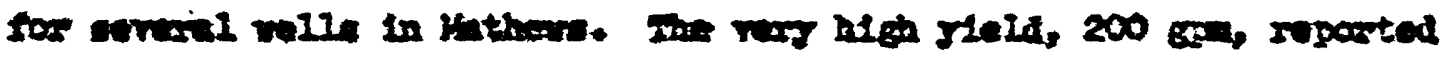

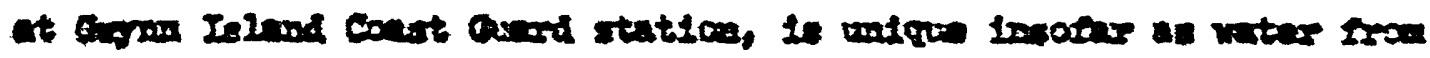




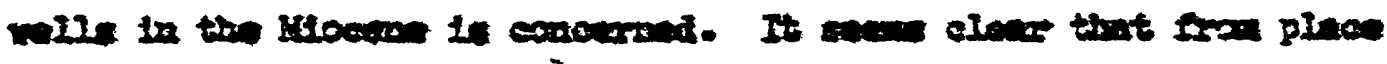

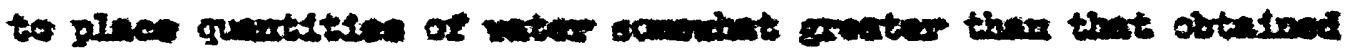

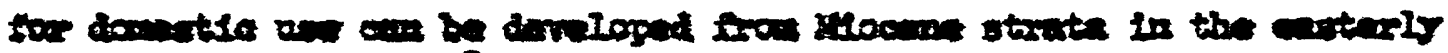

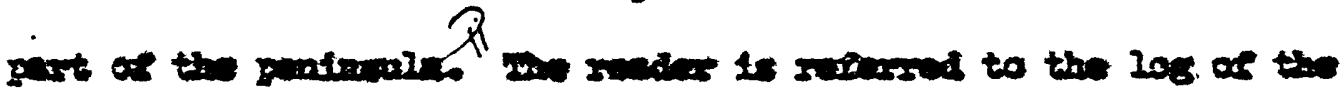

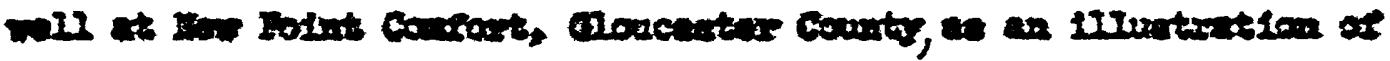

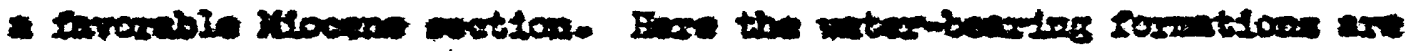

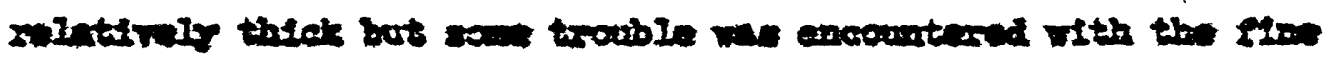

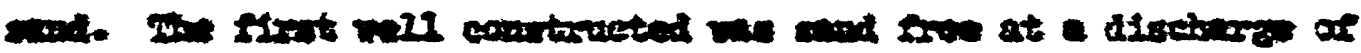

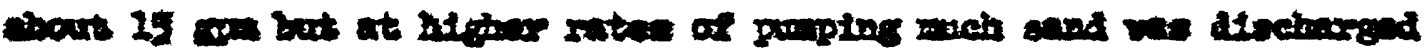

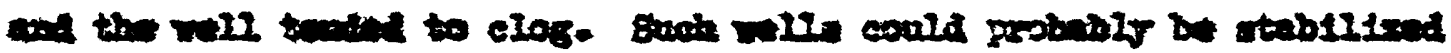

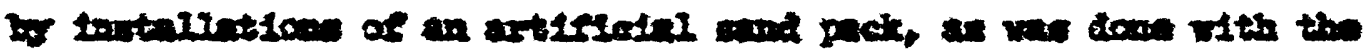

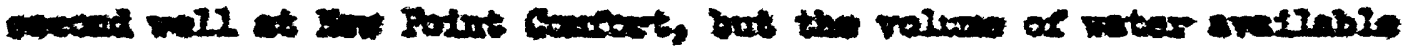

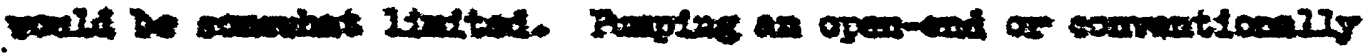

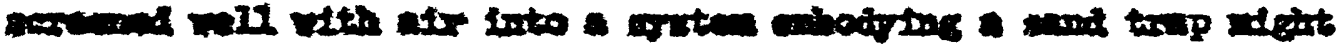

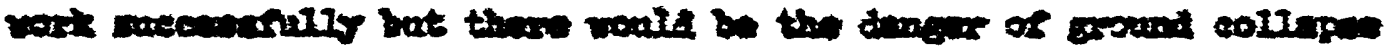

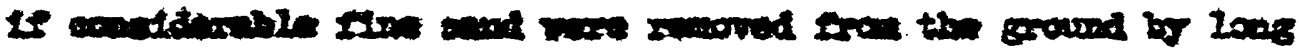
estatenat pupinge

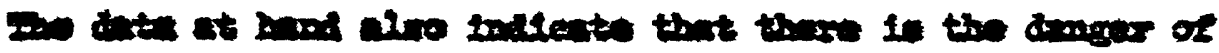

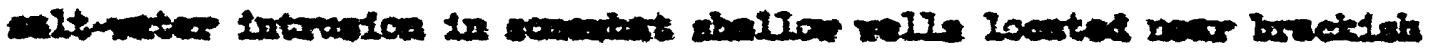

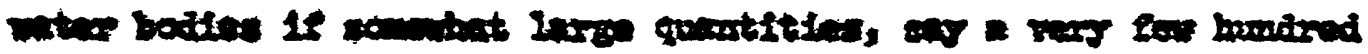

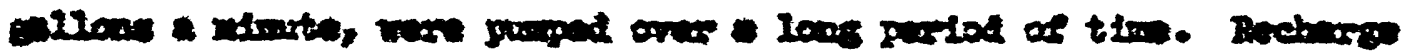

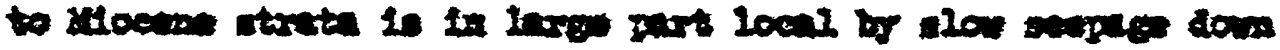

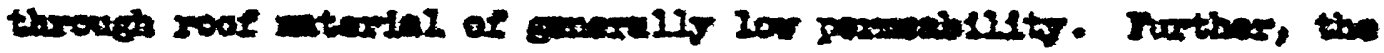




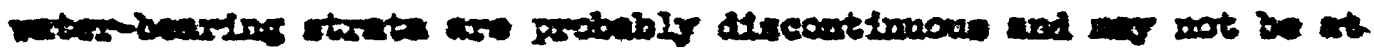

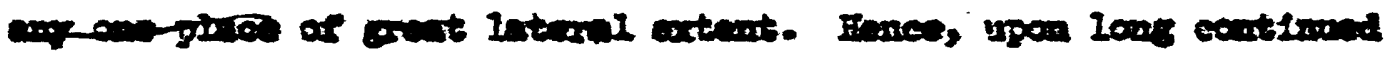

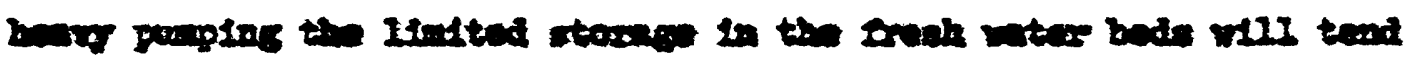

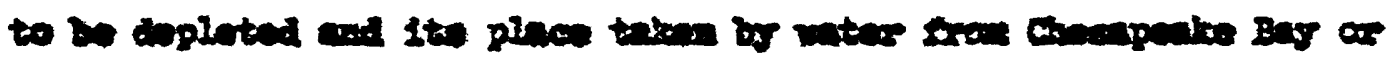

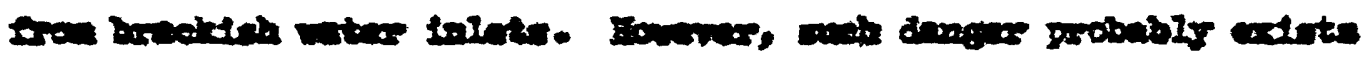

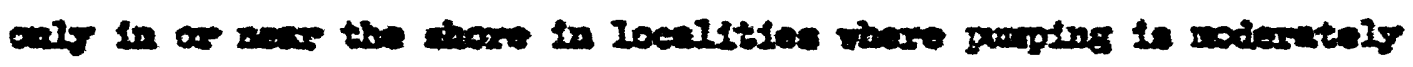

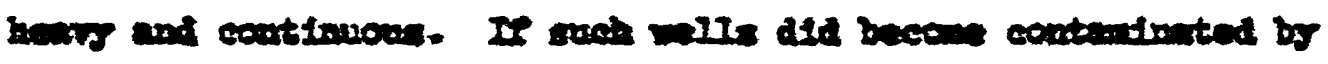

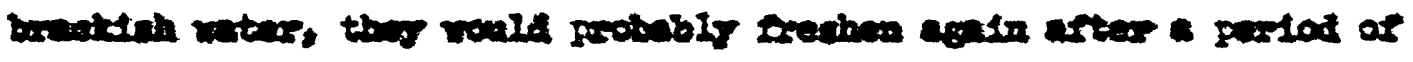

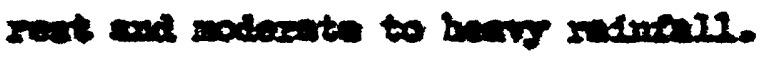




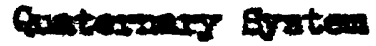 \\ Fintocas Serien - columin Aroup}

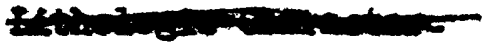

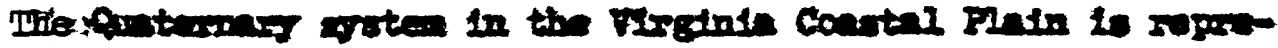

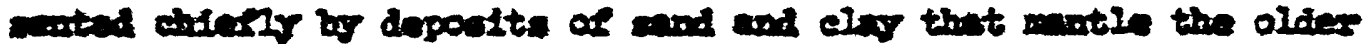

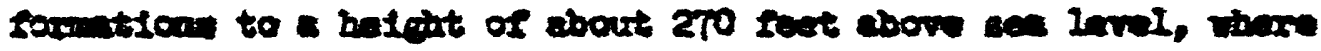

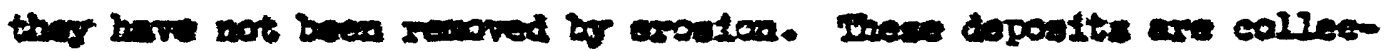

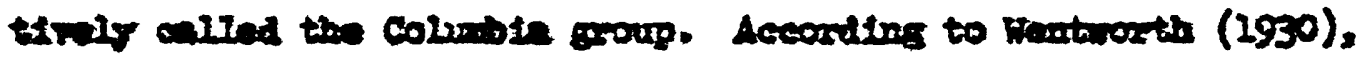

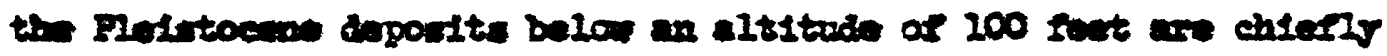

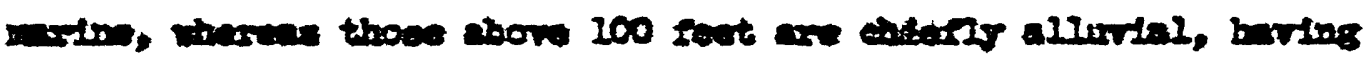

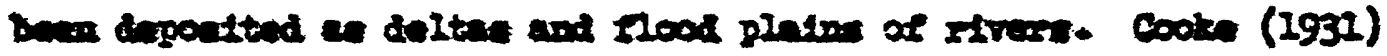

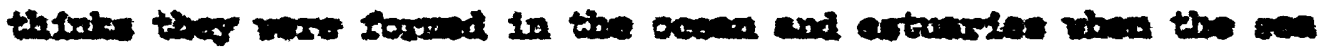

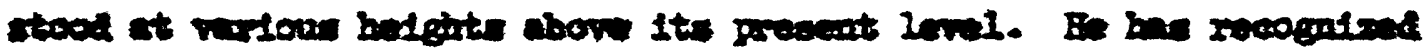

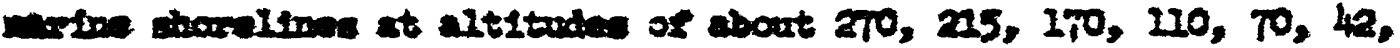

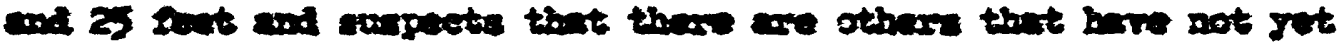
Don atrated.

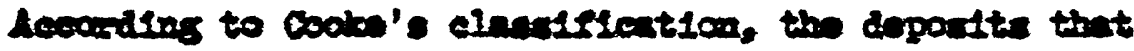

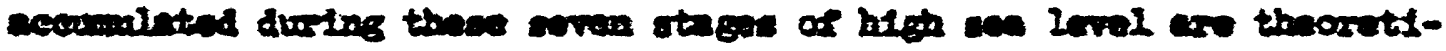

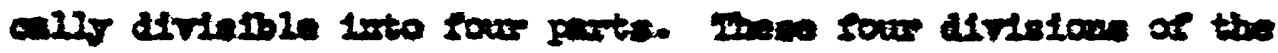

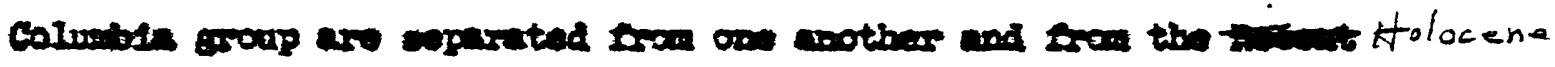

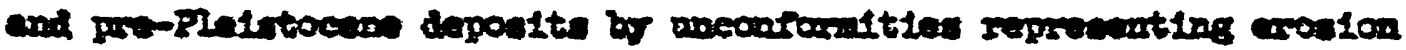

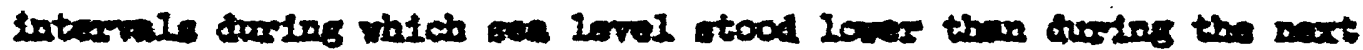

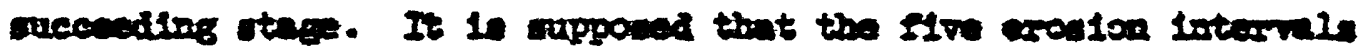




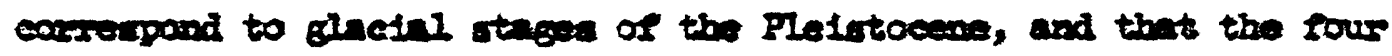

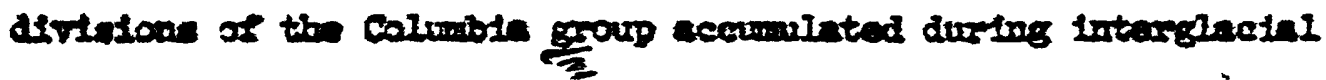
etaene (cooke, 1935).

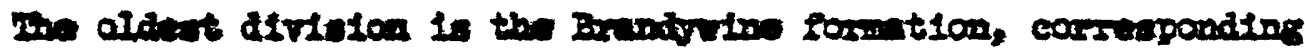

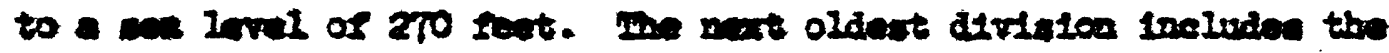

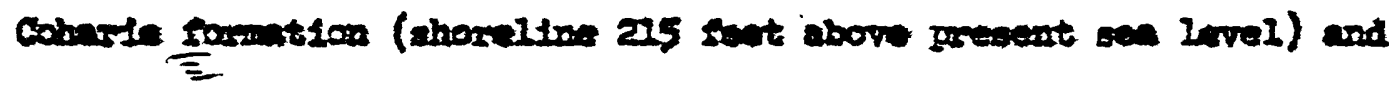

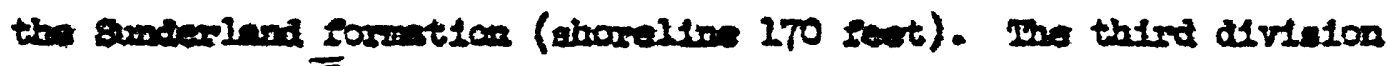
$\equiv$

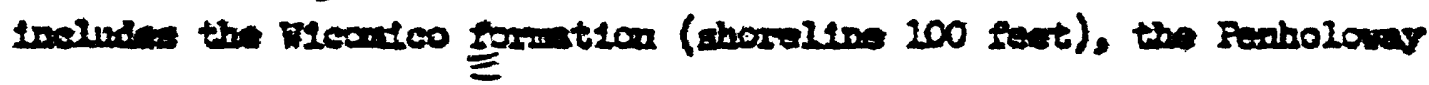

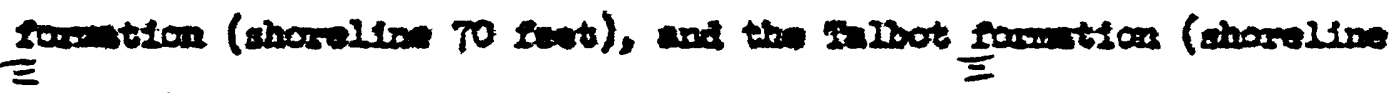

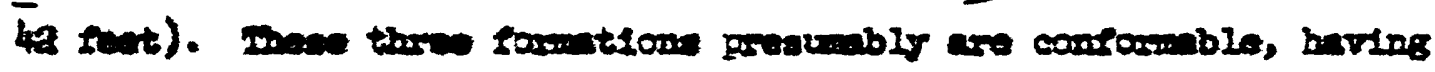

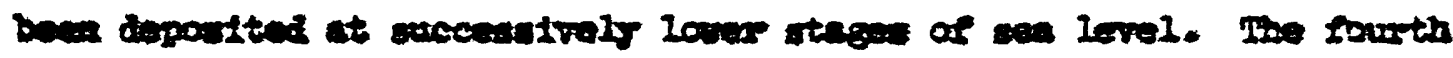

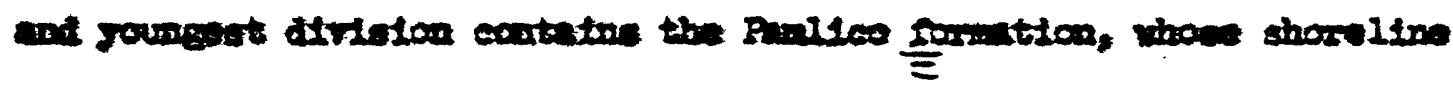

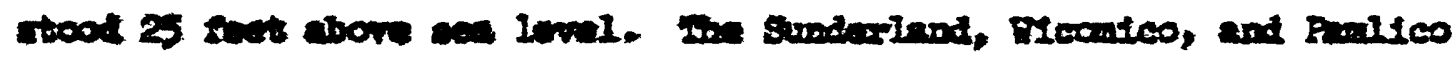

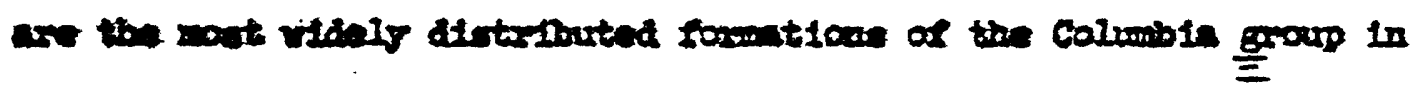

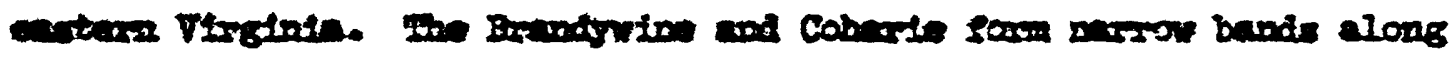

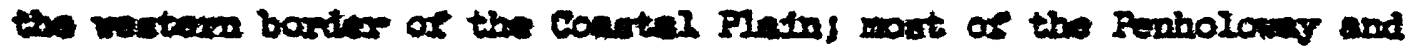

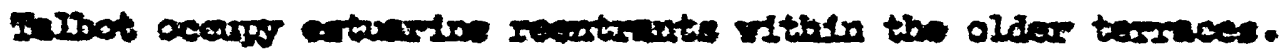




$$
\text { Water - Bicueng Piroristers. }
$$

The terrace deposits yield water to thousands of shallow dug or, less commonly, driven wells. In the lower part of the peninsula these deposits and Miocene beds are almost the only vater-bearing units drawn upon because the deeper formations yield brackish water.

Installations supplying more than domestic needs are almost entirely lacking on the Middle Peninsula, in contrast to the area just east of Richmond where several dairies and schools do develop more than minimum supplies. About 4 or .5 (gallons a minute) appears to be available to pumps operating several hours or longer each day (Cederstrom, 1957, p. 64). One well east of Richmond drilled in the graveliy terrace beds characteristic of the higher westerly part of the Coastal Plain, has the unusually high yield of $36 \mathrm{gpm}$. Such results could only be expected where conditions are especially favorable; a coarse sand or gravelly water-bearing stratum of wide extent which holds a rather large volume of water in storage and which is easily susceptible to recharge. Shallow wells penetrating fine grained sediments, either with small catchment areas or located near deeply incised streams or rivers that permit lateral drainage as springs and seeps, will yield poorly except in periods of high reinfall. .

- The volume of water that might be drawn from shallow wells in wide unbroken terrace $/$ several square miles in extent is large. Unfortunately the development of this water would require installation of multiple vells spaced over a wide area and a considerable 
investment in pumps and connecting pipeline to bring the water to points of use. Infiltration galleries, either open or as intake pipe buried as many feet as practicable below the water table might also be considered. However, except in the eastern end of Middle Peninsula where artesian water is brackish, demands for more than minimum supplies can best be met by drilling deep wells. 
Analyses of samples of water collected from representative deep wells in the Middle Peninsula show that those waters are similar to those present in other parts of the Coastal Plain. These have been described in some detail in Virginia Geological Survey Bulletin 68 and are discussed still further in the literature (Cederstrom, $194 \widehat{6}$ b).

Briefly, waters falling upon the earth along and for a few miles east of the Fall Zone percolate downward to the artesian beds and then move downdip towards the continental shelf. These waters are slightly acidic due to carbon dioxide 8 posorbed from the air and from dissolved plant acids. Upon entering the ground,

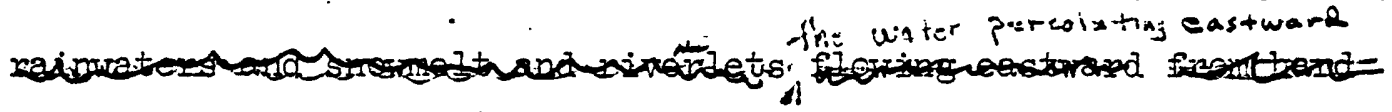
dissolve limy minerals in the earth material and the water commonly becomes hard within a few miles of the outcrop area although the total amount of mineral matter in solution is quite low.

In very short distances, however, these hard calcium bicarbonate waters come in contact with glauconitic (black) sands or other earth material having the capacity to adsork the calcium and magnesium content of hard water and liberate sodium to the water in exchange. The water thereby becomes a soft sodic water although its total mineral content is the same, or even somerhat higher than it was originally. 


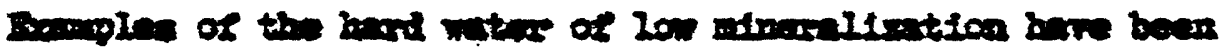

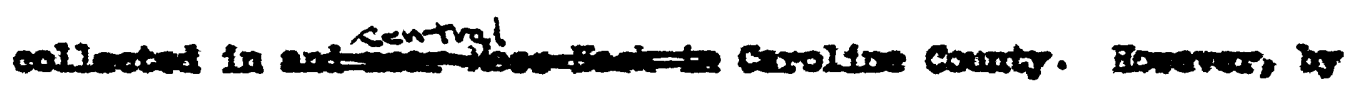

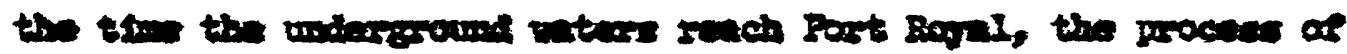

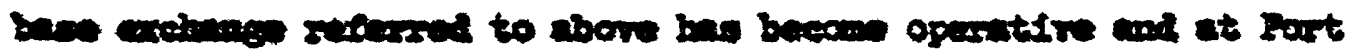

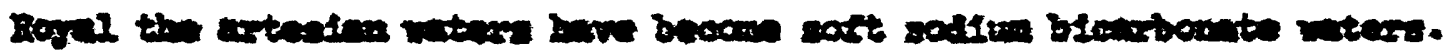

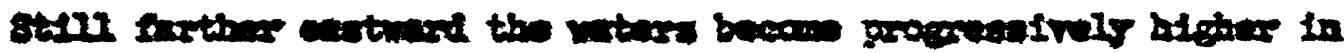

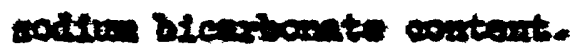

Althoush coutatond in a clowd artenten woten and shut ofs

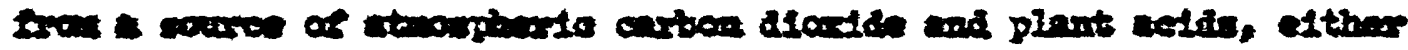

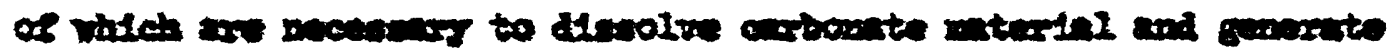

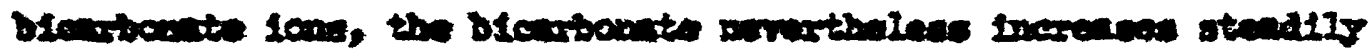

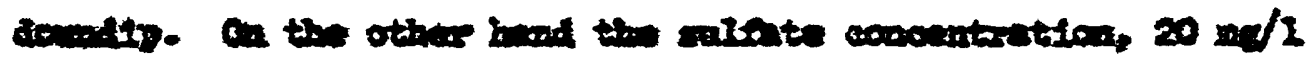

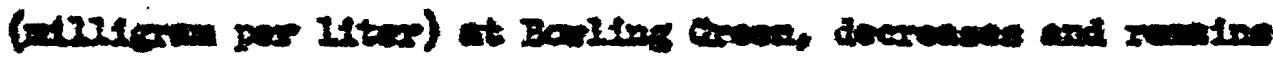
nesporato.

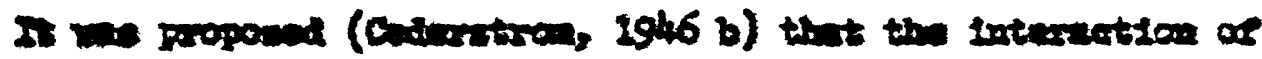

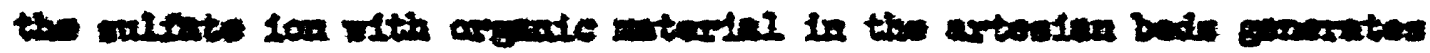

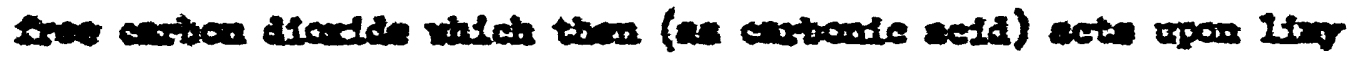

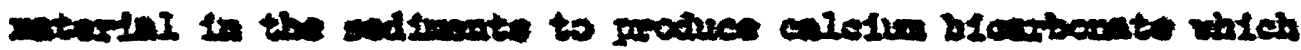

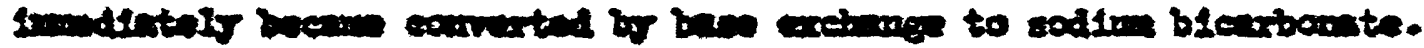

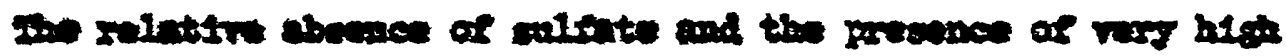

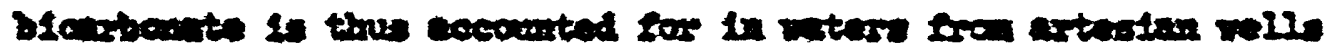

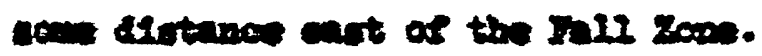

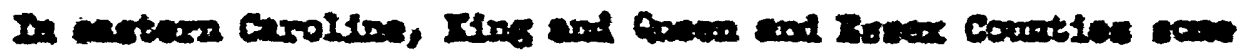

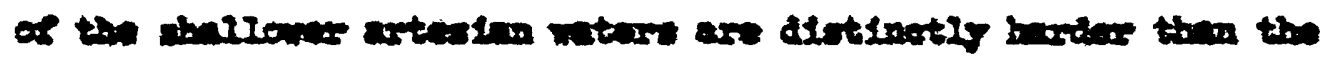




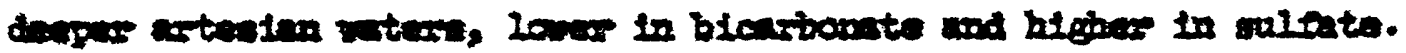

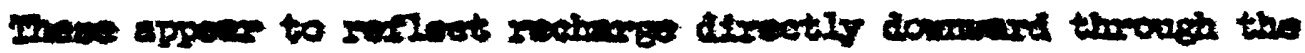

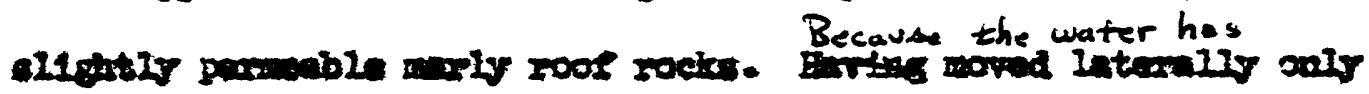

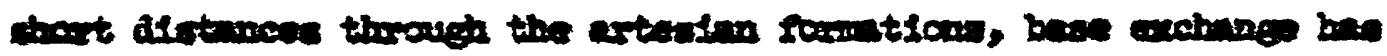

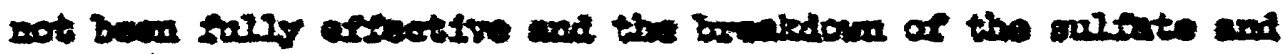

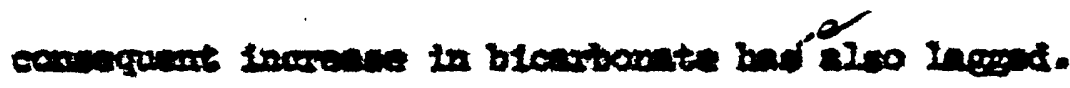

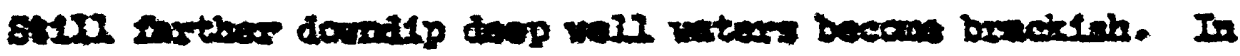

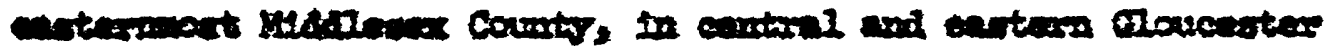

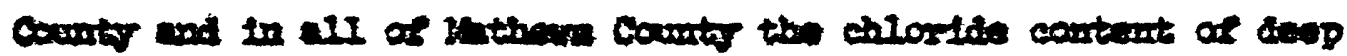

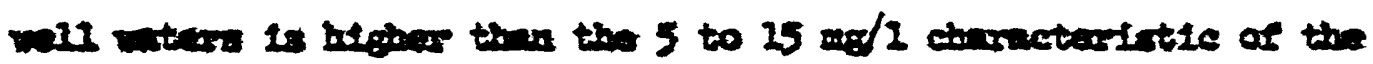

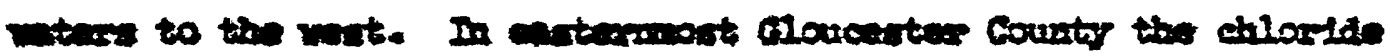

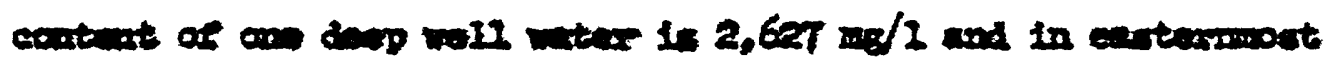

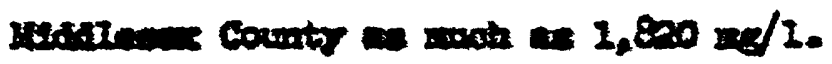

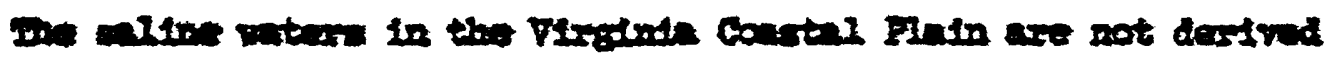

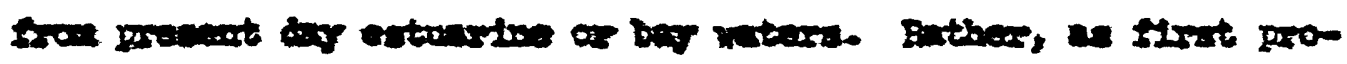

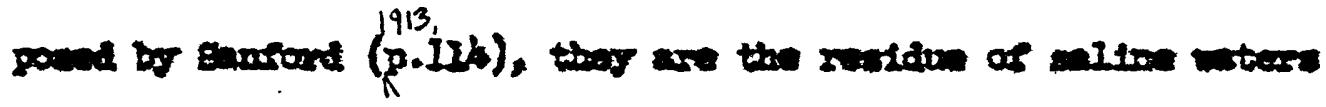

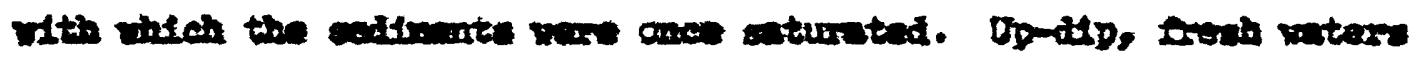

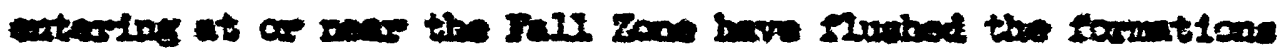

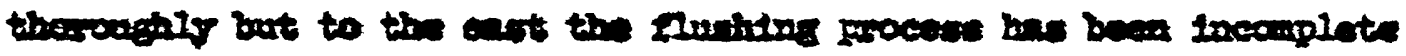

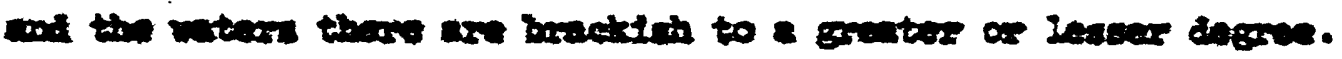

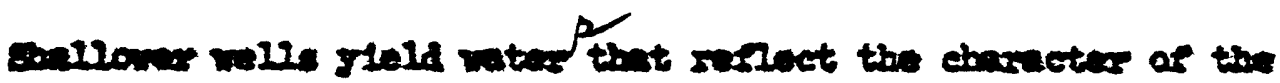

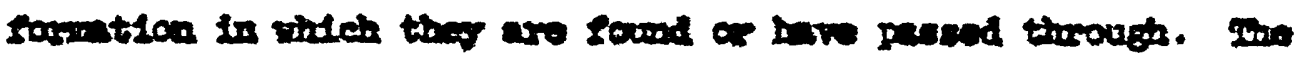

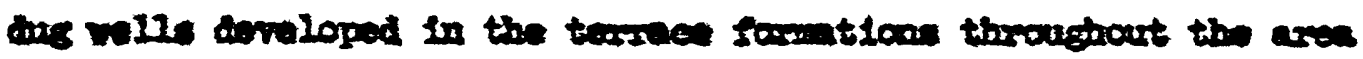

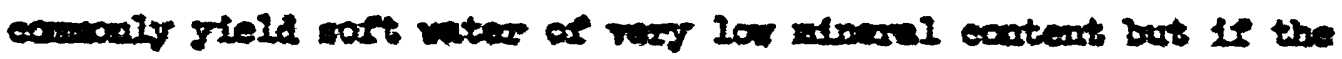

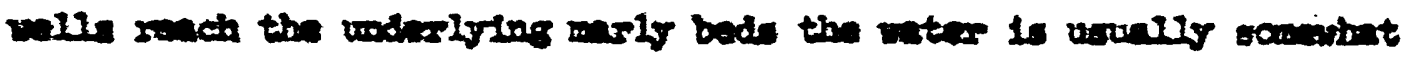




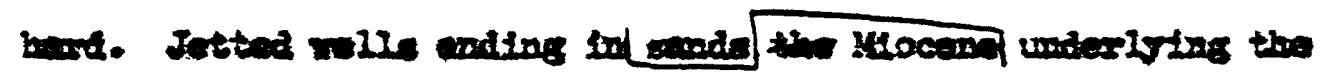

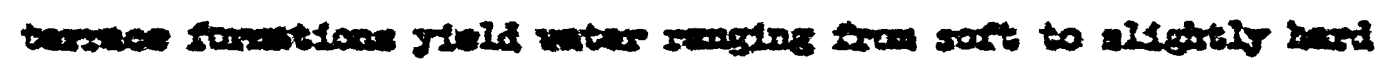

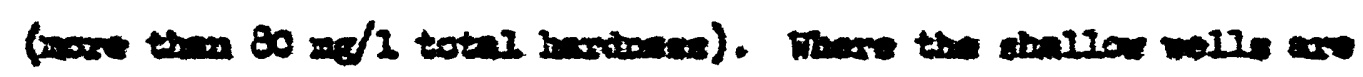

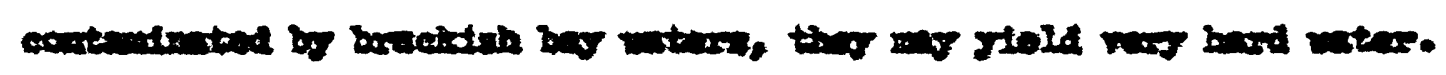




$$
\begin{aligned}
& \text { Oitimin iroun beter Dovelojin ant } \\
& \text { Water-Bearing Properties }
\end{aligned}
$$

Artesian Water

The Coastal Plain Province of Virginia is the one area in the state where ground water in moderate to large quantity can be obtained with ease almost everywhere. In the Middle Peninsula, as elsewhere in the Coastal Plain, only moderate quantities of water can be developed near the Fall Zone. Further, in the lower portion of the Peninsula only brackish water is available from artesian formations. Nevertheless, in an area from Port Royal to Urbanna on the Rappahannock and to the south of that reach, wells may be constructed that will yield $1 \mathrm{mgd}$ ( million gallons a day) or more practically everywhere.

Use of large quantities of artesian water for industrial for almost three decades at Franklin and West Point suggests that equally. lárge quantities might be developed in the Midale Peninsula or Northern Neck area where total draft is at present rather small. This indeed may be a practicable and inexpensive source of a large water supply. On the other hand, it is not to be thought that the available water in the Coastal Plain is limitless. Determination of the amount of water entering Coastal Plain formations is a problem that cannot be completely solved for several reasons. Yet reasonable approaches to the problem do afford an excellent idea of

the magnitudes that should be considered if ar eprivn um melopment of artesian water is to be considered. Such developments might be very large local industrial demands (which seem unlikely at the moment), 
developent of laxge quantities of watar for low flow augmentation of Rappahannoak or Mattapons RAvers, or as suppleanntary supplins for narby os more distant ctelas.

Following the thods used by kack (2566, P. 34; also, Farsde, 1949, P. 236) In Karyland, George Iarver of the U.S. coological survay has calculatad (watton comintention, 1969) that roughly 140 agd could be obtalnod trow artastan formations fron a sartes of closely spaced wells in the ares 12 atles east of the Fall zone fron Frodistaksbuxg to Potersburg utllizing. a armodong to the base of the viocan formations. The Middro Pontnstala "share" of this volume would be about 20 to 25 mgd.

Such a datarnination should bo thought of as onlymalpful rather than absolnte. Flose, the method necesarylly assums that

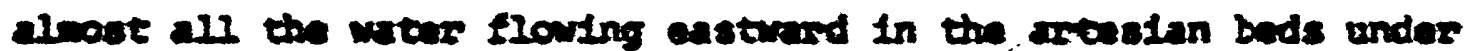
the assoned hydraulfe head can be captured. Because this is mehanically imposeible, the figure given would bo sommat high. second, data on the water-toansalteing proparties of the artesian bads are only rough appoxtantions. The averege tranamastbility ay be greater than the assurand velue of 25,000 gp ft day-1t could hardly bo salller. Indrd, and probably wost loportant, it 1. not known how mach extere water would be transiltted straight downrard through the less perweable roof formattons when erteslan wetar levels are lowred by heavy pupping. Ints asount would be large where the roof formation is andy and swaller whore it is marly. 
A great deal of detailed data would be necessary before any kind of an answer to the question of roof leakage could be made.

Lastly, it must be borne in mind that in the Coastal Plain where formations are more or less continuous, or at least interconnected, over very wide areas, a deep cone of depression around a heavy pumped well or group of wells will spread widely and draw in water from great distances. If a heavily pumped unit were established at Port Royal, for instance, water would flow to it from intakes to the northwest, west, and southwest and a discharge could be sustained that is much greater than might otherwise be expected.

In brief, the problem, generally speaking, is insoluble from the point of view of the tremendous amount of detailed data needed on the highly variable composition of the geological formations, both the artesian water carriers as well as the overlying roof formations. Another approach is to consider what is happening in the Virginia Coastal Plain today. Total withdrawal of reve water might be as much as $85 \mathrm{mgd}$, yet as far as is known, no great increase in the hydraulic gradient from the Fall Zone to centers of heavy pumping has taken place. This suggests that the development of artesian water might be several times greater than the present pumpage rather than only twice as much.

undoubtedly the most worthwhile and critical observation to be made is to see what happens to water 
levels between centers of high discharge and the Fall Zone. On the basis of these observations, reasonably valid conclusions may be drawn to the effect that the great artesian water resource is approaching a certain limit or, conversely, that the limit still lies two or more dimensions beyond present total discharge. The 20 to $25 \mathrm{mgd}$ figure arrived at above has a validity only in showing we are not dealing with ar inexhaustible resource.

Brackish Water

As mentioned above and as discussed in detail in chapters on Middlesex, Mathews, and Gloucester Counties, artesian beds in the lower Middle Peninsula yield brackish water. The presence of this water not only precludes the possibility of obtaining bounteous supplies of fresh water very cheaply but is a source of danger to heavy pumpers in the adjacent fresh water area. Where heavy continuous fresh water discharge is maintained near the boundary area between the two water types, a cone of depression is created that will spread eastward go well as westwardE

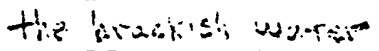
and ${ }_{A}$ will tend to move inland and contaminate the fresh water vells. The spread of a cone tending to induce westward movement of brackish water will depend, among other things, upon the long term sufficiency of fresh water moving in from the Fall Zone area to the rells. With ample fresh water moving eastward, there will be little or no danger of brackish water moving updip. 


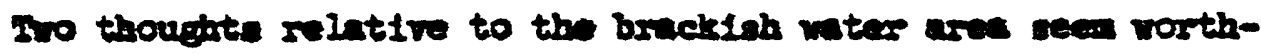

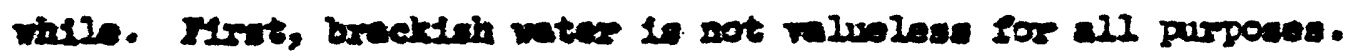

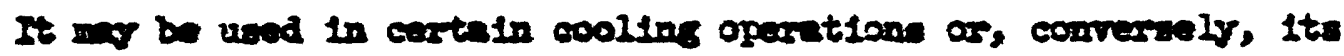

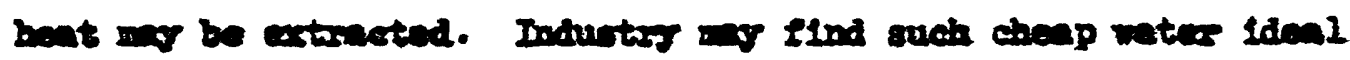

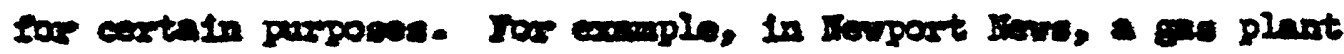

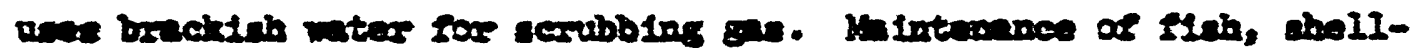

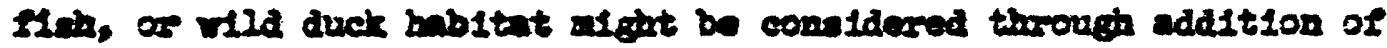

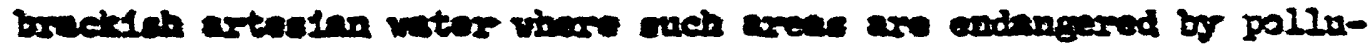

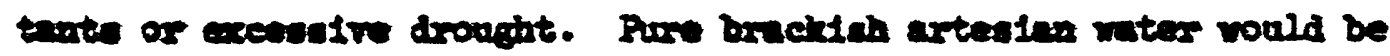

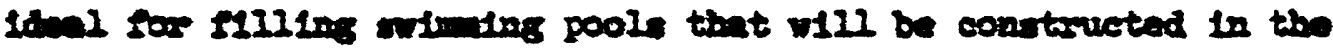

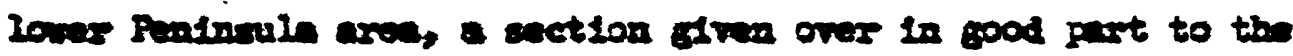
socention somitury.

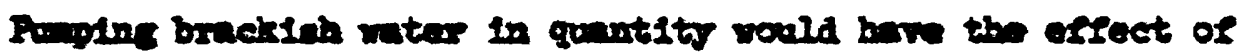

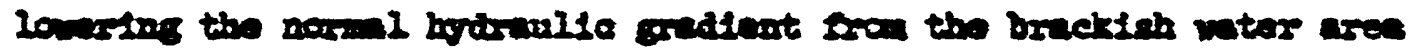

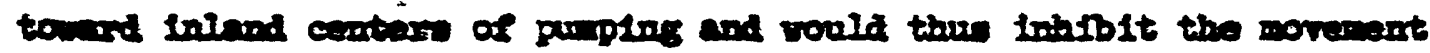

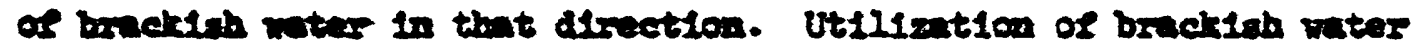

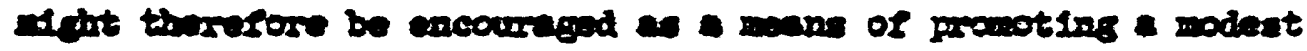

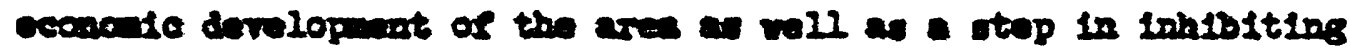

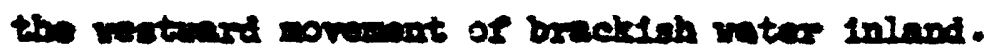

\section{Rechare of Brweidin Water strata}

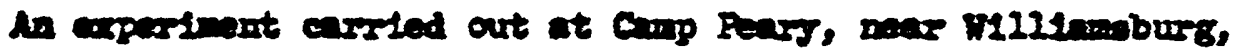
Va., showed thet it is pasalbie to atose freah rater in brweicleh

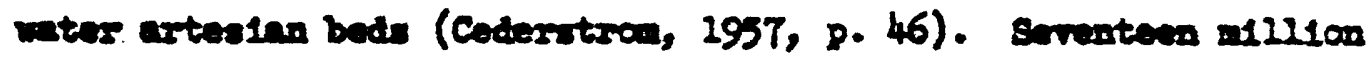


gallons of water from a surface supply were recharged through a deep well. After a brief interval the well was pumped and it was found that the first half of the recharged water was fresh. With continued pumping the water discharged gradually antook on more and more the character of the formational water.

The practicabllity of storing very large quantities of fresh water in brackish water formations is being tried out under carefully controlled conditions at Norfolk at this time of writing.

In the lower Middle Peninsule it may be worthwhile to consider the desirability of similarly storing fresh water in the breckish water artesian beds. Fresh water in modest quantities is generally available there from shallow wells. Small quantities might be infected contimuously during, say, 9 months of the year to provide a larger supply to be pumped back during the three sumer months of much higher demand. It should be pointed out that there are technical problems in the functioning of such a device and it would be best to seek specialized professional advice before carrying out any recharge operation.

In providing larger quantities of water than are now available In the lower peninsula, the alternatives to a deep well recharge operation in the lower peninsula appear to be (I) small surface water reservoirs subject to high evaporation and pollution, in many Instances requiring long pipelines to point of use and liable to failure in times of drought, (2) batterles of shallow wells requiring much flat land as well fields, relatively high maintenance costs and, in most instances, considerable investment 
In plpe hookupe and pipeline to polnt of use or, (3) a trank itae

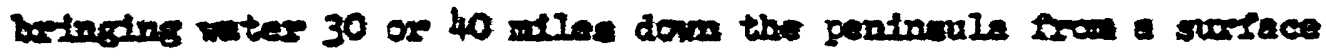

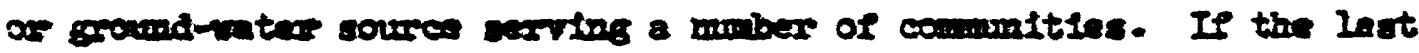

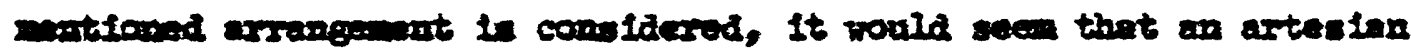

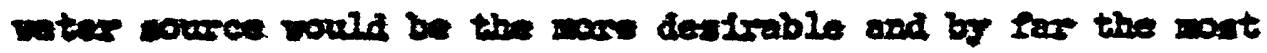
econcontenl in that pure vater could be obtained at verg lon cost at the source and ellaration roula not be required. At the present atege of themologr and antlelpated noede of the lover pentnanis are in adnd, a dealisiration plant conld hardir be considered in thet an accupteble cout to the average compunor could be achleved

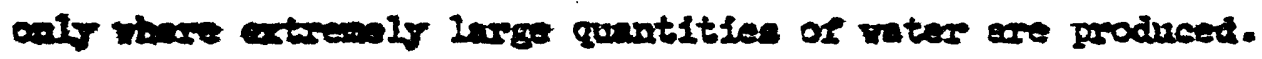

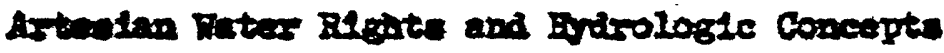

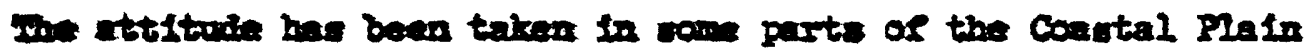
that a polftion a rubifinion own the rater that 11es in the crtenten sometions baneath that nubdfris10n, prescumbly based an the concapt that artasing vatex is a statle renource not easiy replentimable.

Inowing that mail roter enters the artenian beds along the

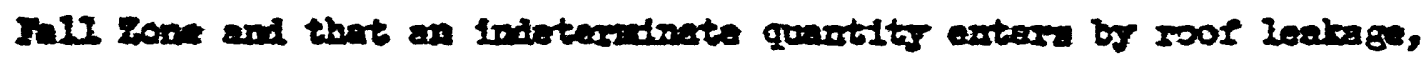
where the whllor water table in hlober than the arteatan bead, and

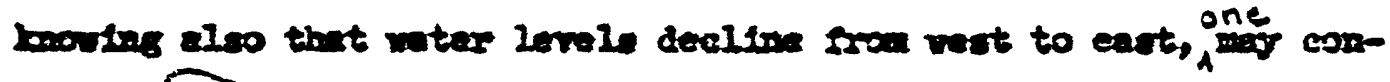

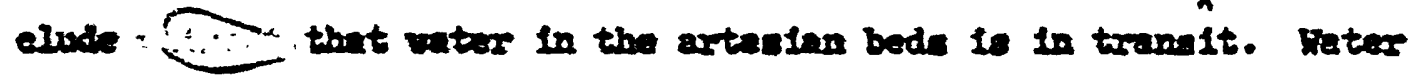
enters the artecian beds in the reatern poct of the coustal PLain,

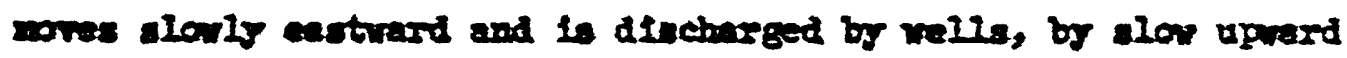

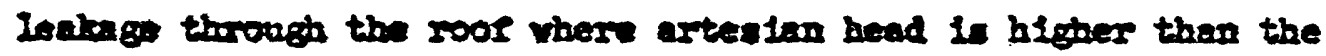
challow rater table 
and perhaps moves on out toward the Continental Shelf. A continuous replacement of discharged water is going on.

Darcy's Law shows that the volume of movement eastrard depends on (1) the character of the formations, (2) their thickness and, (3) the slope of the water table. The latter factor may be thought of as the pressure head. The first two factors are fixed but the slope of the water table is variable.

Under natural conditions, that is, before the drilling of many wells beginning about 1890, the slope of the vater table was. very gentle and hence the amount of water moving eastward in the Coastal Plain formations was small. Discharge was out to sea or upward through the roof.

With the construction of many hundreds of flowing wells on low ground, artesian water levels were lowered sharply in the vicinity of those well fields.. The pressure system was tapped at low levels by these wells (e.g., artesian head may have been 30 feet above sea level and the well outlets at 5 or 10 feet above sea level) and water flowed to these wells from adjacent areas of higher pressure. The combined effect of pressure lowering extended_many miles back and in the Fall Zone area water levels may have declined a few inches or more.

By 1920, the total movement of water eastward through the artesian beds was undoubtedly greater than it had been in 1890 . Not only do we visualize the discharge of many hundreds of wells, some of which had flows ranging up to 50 to $100 \mathrm{gpm}$, but we see 


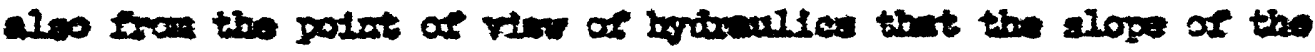

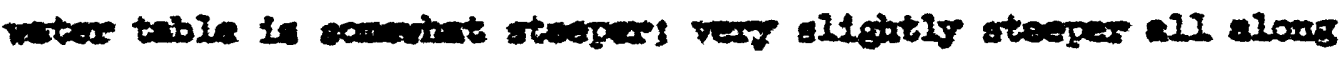

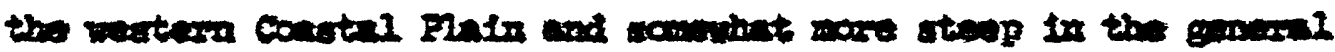
are of the sowing nile.

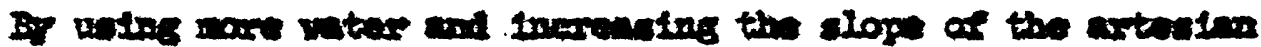

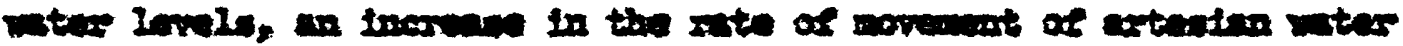

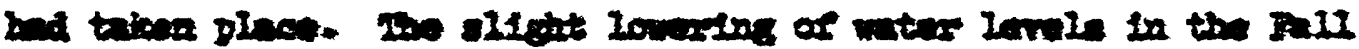

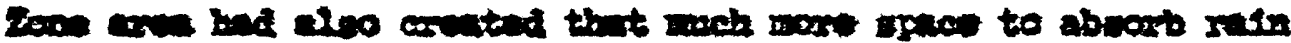

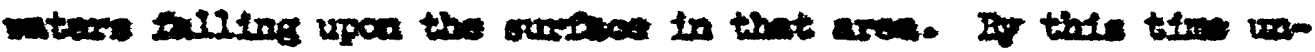

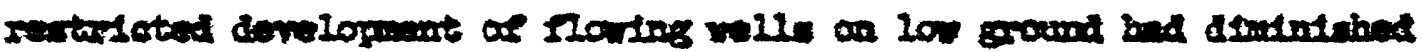

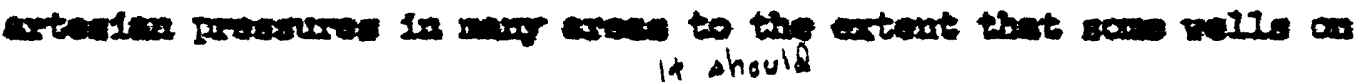

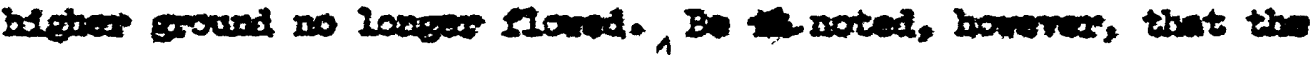

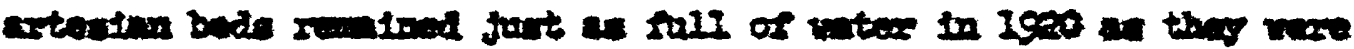
in 1890.

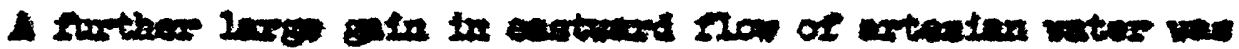

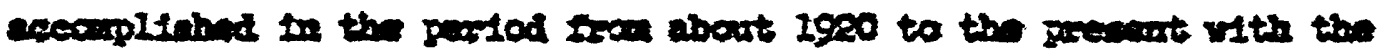

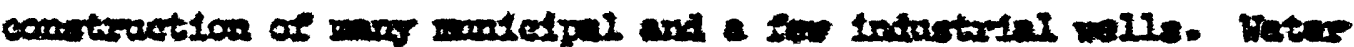

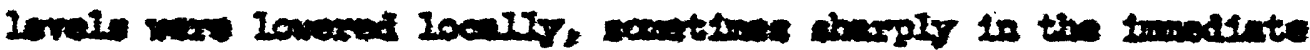

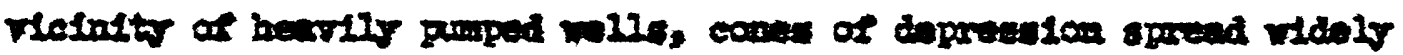

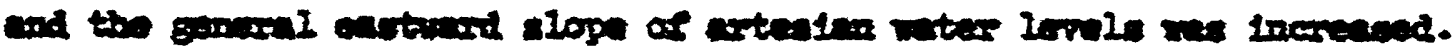

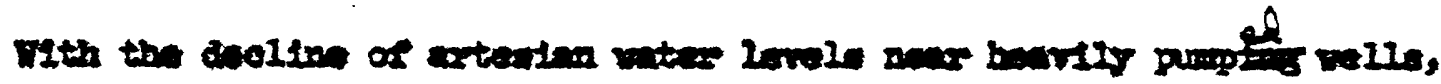

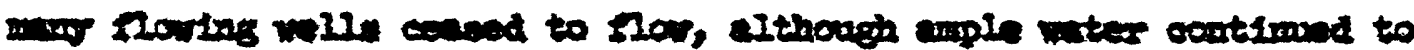

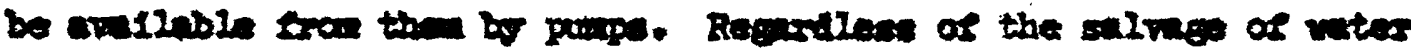

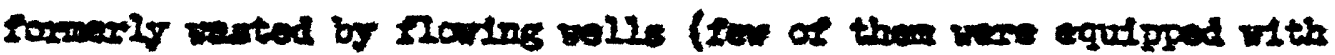
chat-ose virea) 
it is apparent that a very much greater volunc ol: water is being discharged at present than wue true in 19c0. lillofly, more water was made available by drawini: from lower lovels (come pump intakes draw water from 50 feet or more below the urufuce). Only by using more water, accomplished by depressinc artwian water levels locally and increasing the castward artesian prescure slope, was it possible to gain more water.

? At present the artesian formations are still as full of water as they were in 1890. "Then, the concept that artesian water beneath the land is as static as the land itself is utterly without foundation. The concept that the supply is linited is valid only when we, think of total discharge several times greater than the present discharge. Certainly a cone of depression develops around a small flowing well or a group of heavily punped municipal or industrial wells but this "cost" of lojered hoal is one of the prices of acquiring additional water.

From a long term point of view, it wisl io impossible for any individual or political subdivision to "rmer:" whet they consider

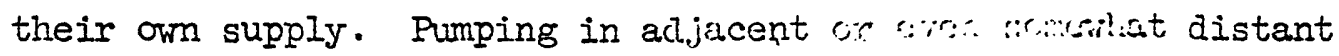
areas will slowly draw in artesion water "\%,... niteryer pressures are high, following the accepted bincip. '… micr flows downhill or, in this case, the pressurio :jo,..

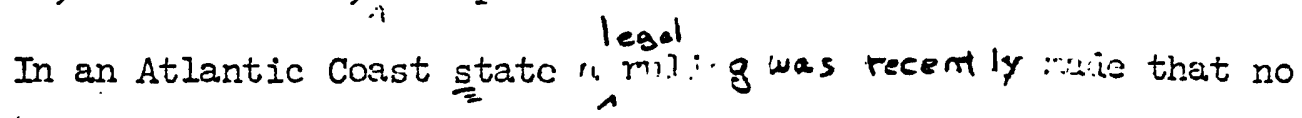

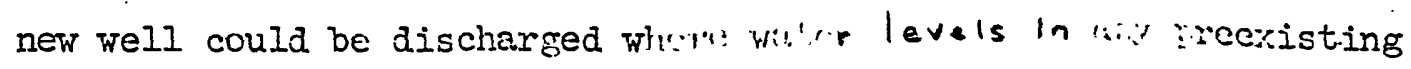


vall would be affected. Oovlousiv, since an increase in gradient 1. requtred to bring in additional rater, no new wells can be conitaricted in the Coastal Plain of that state if the saling is ealnered to.

In conclusion, it in mgrosted that it is a gropers function of the state to addrese itwelf to the problem of ranagument of ground rates in the Coatal Flain. Mach more vator is arailable by degreastog rater levels localis. Whe effect of lower water levelo

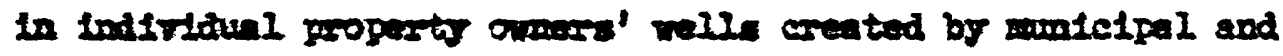
indurtal pouplorg and the interferonce of mustelpal and industarlal wells upon each othex is prosently desarving of much deliberate thought and erentanl conclusions based upos the podrologle, economic, and acetal factors imolred.

\section{Bnal100 Deter}

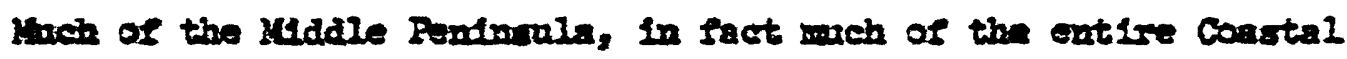
Finin, is covered by gands tarrecen, san of whtch are a mile or two in length and perbup a mile or mose vide. Such essentisilf Plat ranty areal wo subject to rapid recharge and way absost, on the averag, as mech ae a illion gallonis of rater a dor per squaro mile.

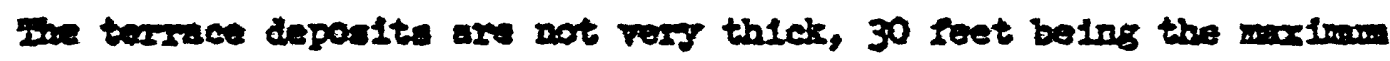

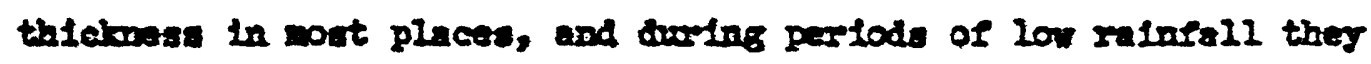

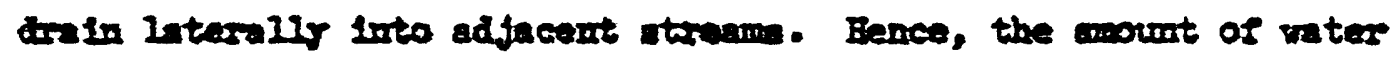
arallable at as on place is rather small and not too great a reliance wa placed on thels capacti to supply adequate vater 12 tives of drought. 
Connecting up a series of shallow wells and delivering the water pumped to some distant point of use would be very expensive and the volume of water delivered would vary greatly from season to season. However, when we consider that the Coastal Plain is roughly 16,000 square miles in area and that a goodiy portion of it is covered by terrace formation, perhaps 10,000 square miles, we are dealing with a recharge of $10,000,000,000$ gallons a day, a volume that is much too large to be ignored in long range planning:

As stated, capture of this water, in small or large part would be expensive by conventional means. Storage of the captured water would also be a problem.

It seems entirely possible that terrace water could be drained down into the huge artesian water reservoir by means of $(f \cdot g, 2)$
suitably constructed recharge wells, thus eljminating both the cost of a complex small yield well system and storage facilities. Such proposed recharge wells would consist of two elements; a 6- or 8-inch diameter "shallow" collector well extending to the bottom of the terrace formation, with two or three feet of screen near the bottom, and an inner 2-inch diameter injection well. The inner pipe would rise just above the level of the top of the screen of the outer larger diameter well and would extend down to an appropriate artesian formation where it would terminate in a short screen. Thus, where differences in head exist, water would drain from the terrace sands down into the artesian formation. With the 
Flguro 2.-Suggestod design for dratnege-rechergo woll.

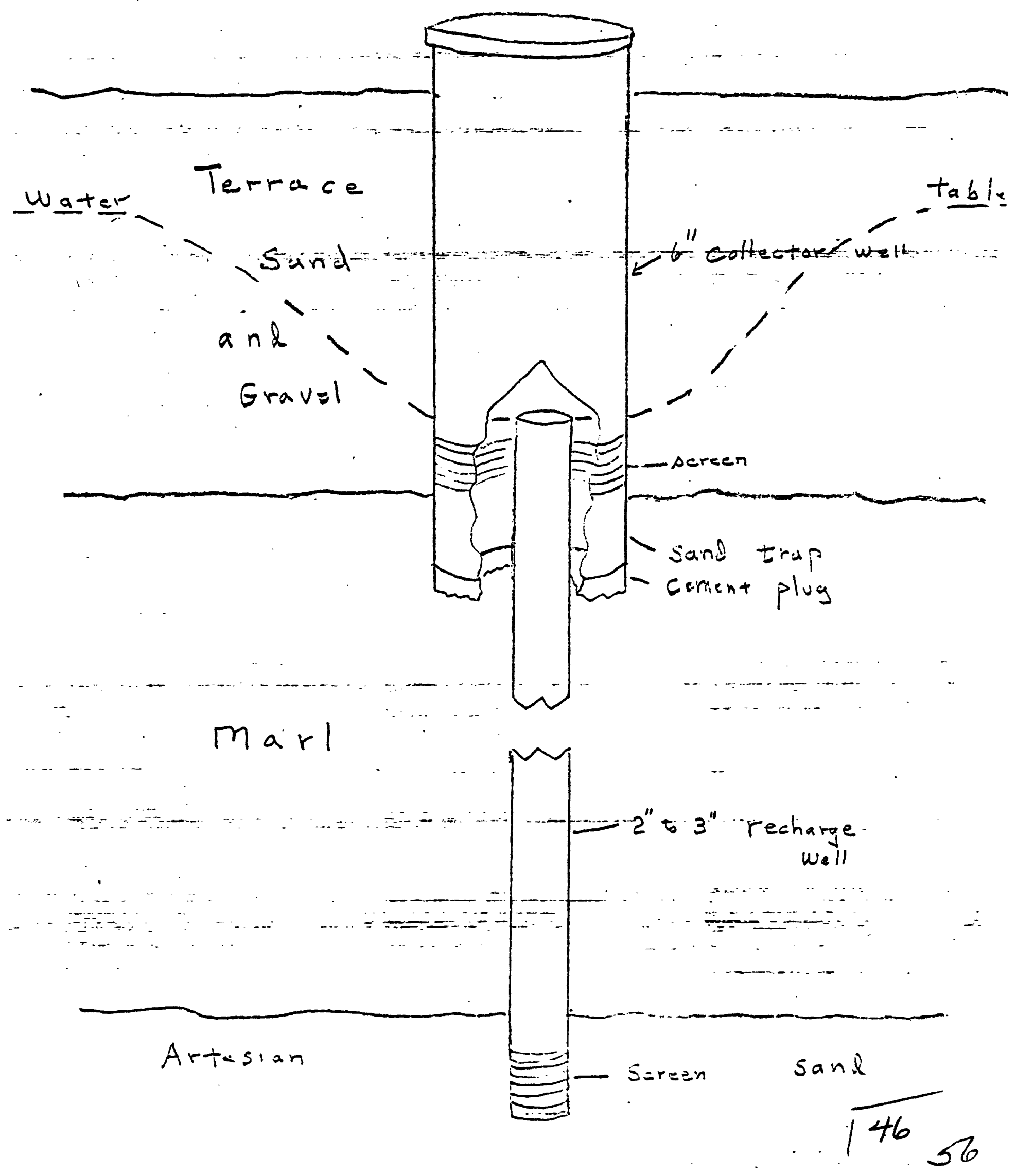


top of the injection well extending slightly above the top of the collector well screen, the water level in the terrace formation could not fall below the screen level, unless influenced by other factors.

Such a device was constructed in Anchorage, Alaska (Cederstrom,

\section{and Waller}

Trainer, $\wedge$. 64). The experience showed that it will be necessary to work out economical construction and development techniques by experimentation but there is no reason to doubt that this can be done.

The water recharged into the artesian beds would help restore artesian pressure head locally, thus lowering costs of pumping from deep wells. In substituting injected terrace water for artesian water moving in from long distances, an addition to the total deep well supply would be gained.

As inferred in the paragraph above, the recharge water would, in effect, be picked up again by a nearby artesian well and used locally or piped to some distant point of use. To be quantitatively significant, multiple recharge wells would be necessary. In many places extra recharge to the terrace formations in which injection wells are sited could be gained by leading spring or stream water flowing from higher terraces across the lower terrace. Assuming the ground was available, normal overland drainage from the terrace in which the well field is located might be inhibited. by small earth embankments or by ditching. 
The terrace water, under nearly all circunstances, would be an organically pure water in that the formation itself functions as a filter sand. Likewise, upon discharge from the injection well and in migrating to the pickup well, still further filtration of the water would take place. Naturally, in such a proposed scheme, protection of the system from pollutants of all types should be rigorously enforced.

In conclusion, the device could be used simply to maintain artesian head to a greater or lesser degree where head has been lowered by somewhat distant heavy pumping or it could be implemented on a much larger scale for the purpose of adding significantly to the total supply, particularly near centers of heavy pumping.

The device as sketched out above will not function particularly well in introducing fresh water into brackish artesian formations in much of the eastern Middle Peninsula area. A great deal of the land there is low, artesian levels may be as high as the land surface and sufficient head differential is lacking. On high ground drilling 2-inch injection wells to the depth required, 700 feet or more might be both difficult and overly expensive relative to the improvement in quality of water that might be expected. 


\section{Logs of Wells}

Following each county discussion a number of well logs are given. These are, with few exceptions, drillers' records of formations penetrated and are the basis for most of the discussions of the geology and, with the well records, the basis for conclusions regarding the hydrology. Many of the logs were obtained directly from the driller, others were reconstructed from suites of samples furnished by the driller. Several logs were obtained from files of the Virginia Division of Mineral Resources and a very few were taken from Samuel Sanford's report on the ground-water resources of the Virginia Coastal Plain.

All designations of the geological age of formations penetrated were drawn by the writer. Boundaries were generally drawn on the basis of lithology but in a very few instances were based on study of microfossils in samples at hand. In many instances, a comparison with the better known geology to the north and south of Middle Peninsula was helpful.

\section{E.szoside C.atis}

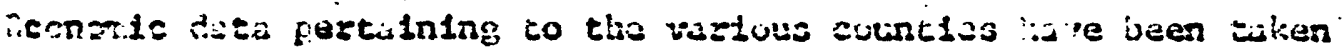

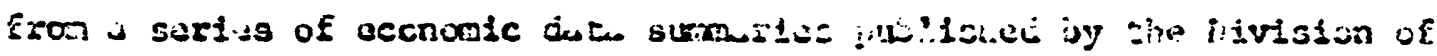

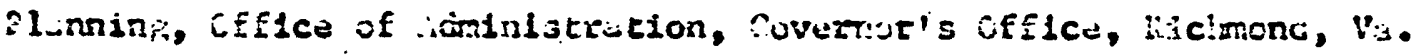




\section{Croline count}

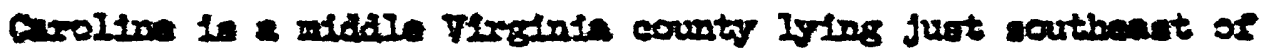

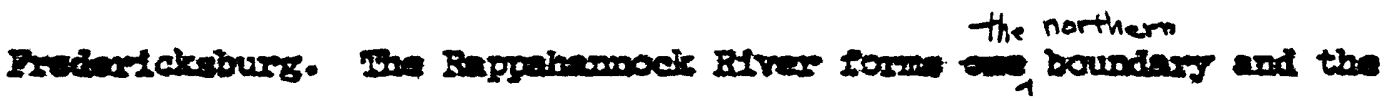

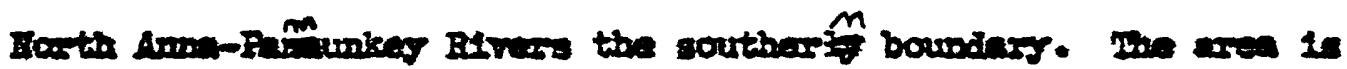

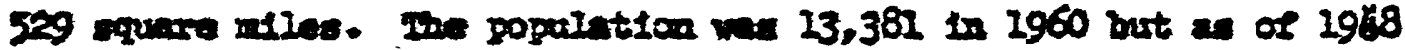

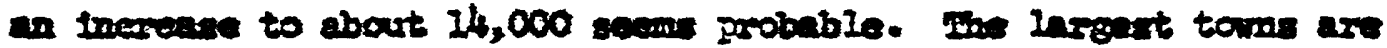
Bowling Cumen, with a popuintion of 528 in 1960 and Port poyal with 123 in 1960.

200 popaletion wa about bale sural in 1950 but is extimated

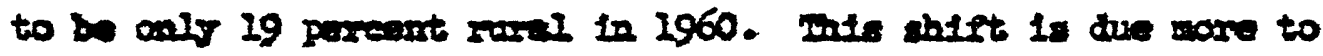

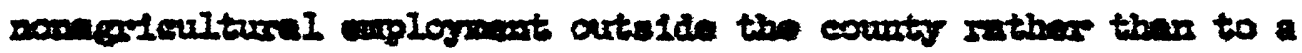

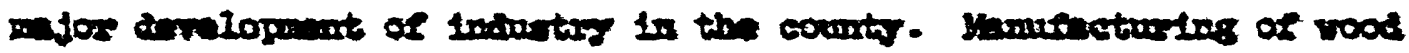

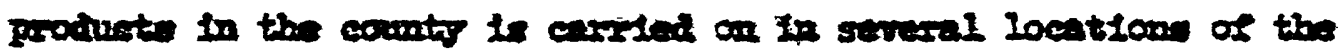

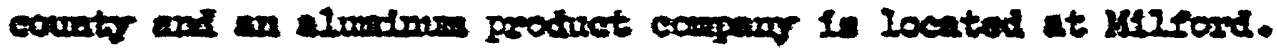

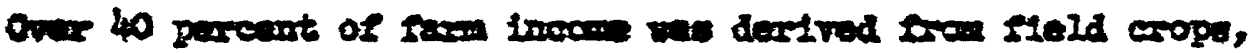

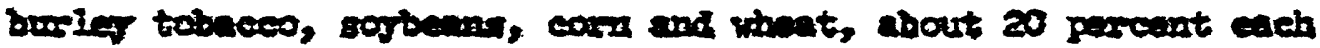

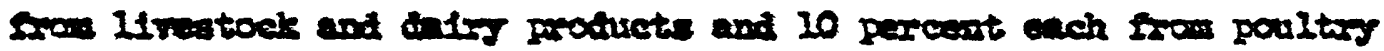
and sonant producto.

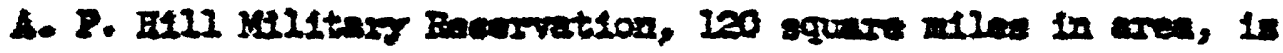

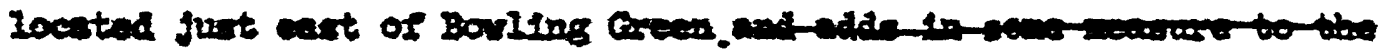

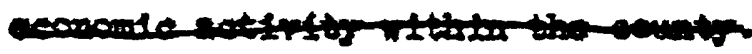

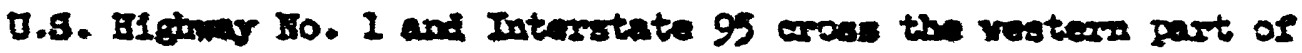

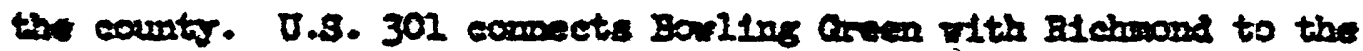

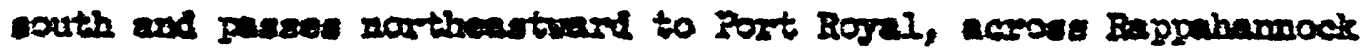
River and on to Muyland. State Route 2 connects Bowling Gean Ith Iroderfickaburg. 


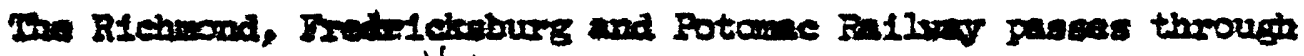

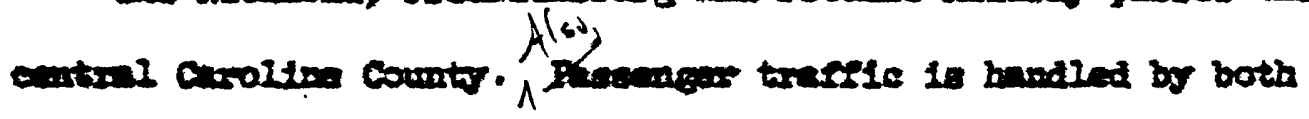

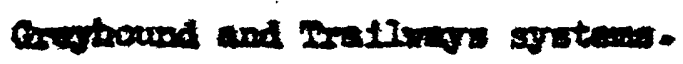




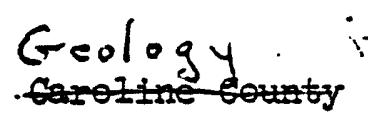

Caroline County is the westernmost of the Middle Peninsula group of counties. Here unconsolidated Coastal Plain sediments lap up upon the older crystalline rocks making up the Pledmont Province. The crystallines are exposed in the westernmost part of the county.

The Geologic Map of Virginia shows that the oldest sediments exposed are those of the Aquia Formation nem-considere to be of Paleocene age. These crop out along Rappahannock River in the vicinity of Moss Neck and along the upper Mattaponi in the vicinity of Milford. Sediments of Eocene age, the Nanjemoy Formation, overlie the Aquia Formation and are exposed along the Rappahannock and the Mattaponi. However, throughout the greater part of the county, Miocene marls overlie and mask the older formations and they in turn are obscured to a large degree by a veneer of sandy terrace formations of Pleistocene age.

The Mattaponi Formation of Paleocene and Late Cretaceous age is present below the Aquia Formation in central and eastern Caroline County but is not exposed anywhere in the county. The still older Potoma'c group of sediments undoubtedly amespent at depth in central and eastern Caroline County but little is known of them.

\section{Pre-Gretaceous Basement Rock Triassic System}

Basement rocks have been penetrated by several wells in western Caroline County $(1-6,8,16,41)$. Table 1 and fig. 3 

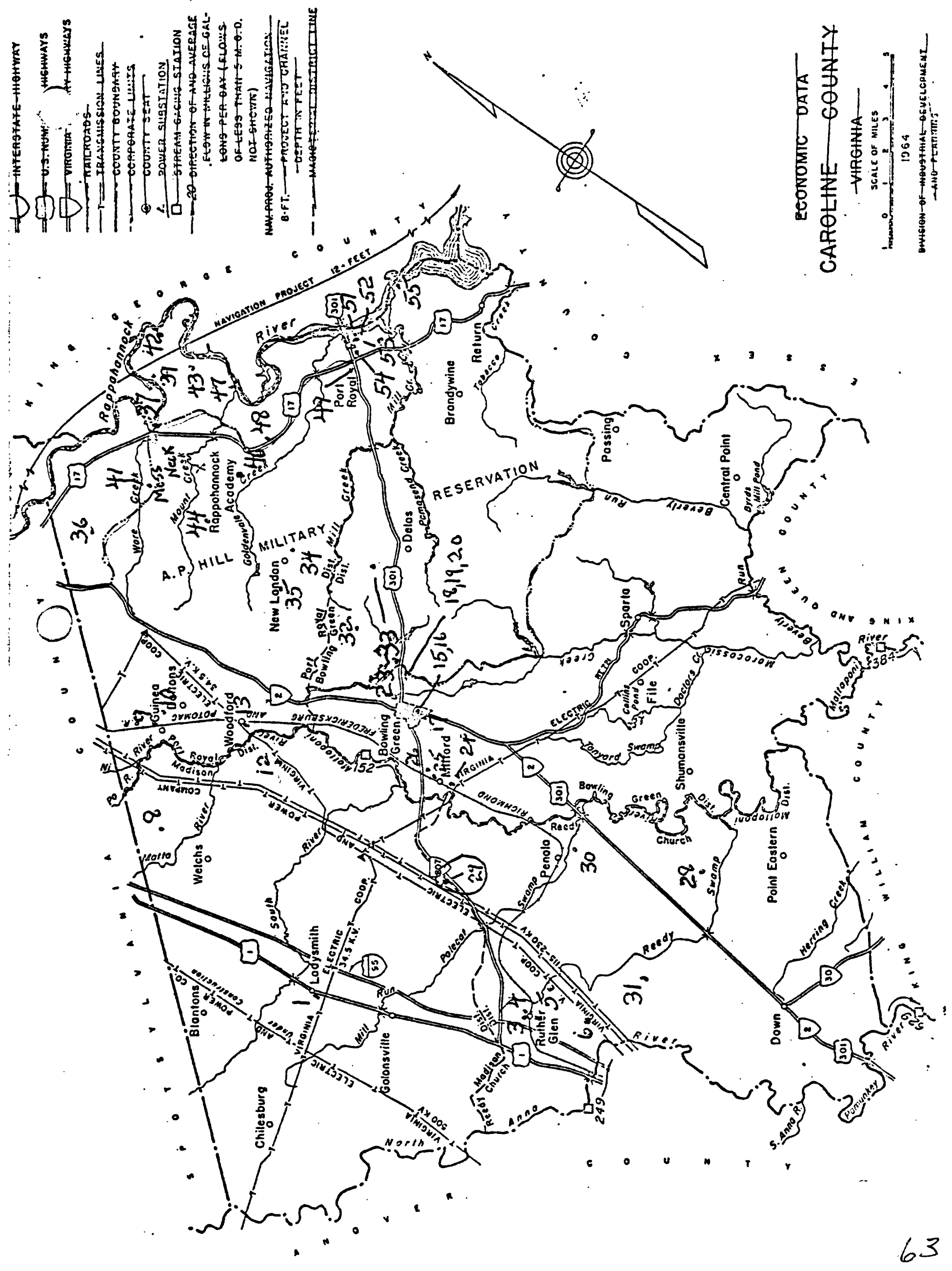


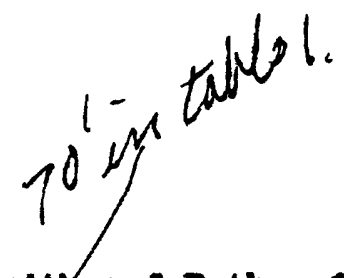

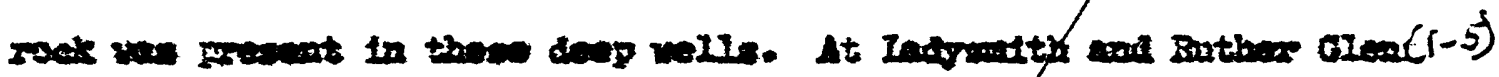

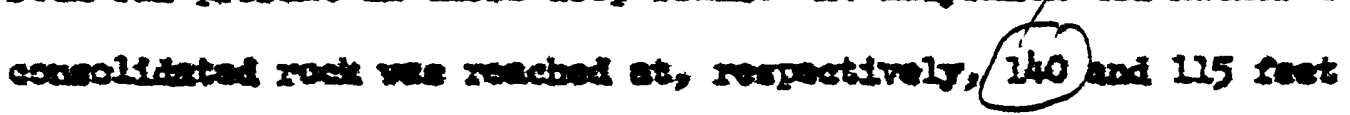

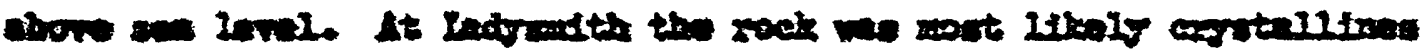

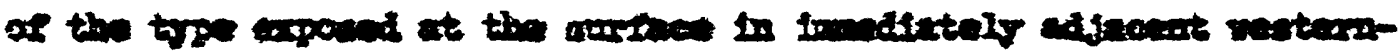

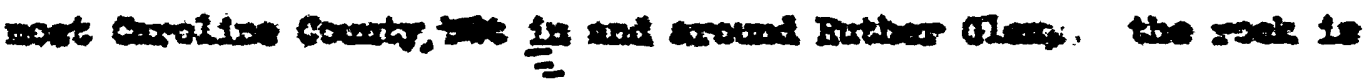

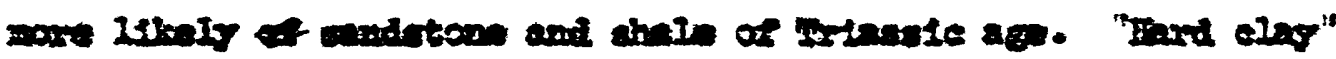

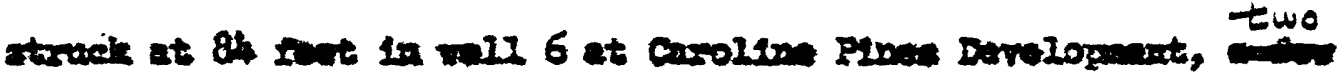

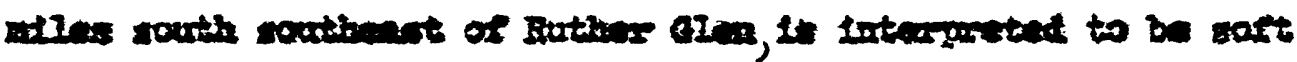

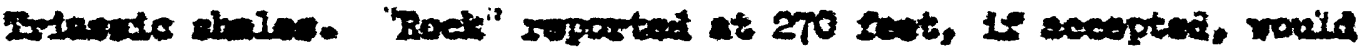

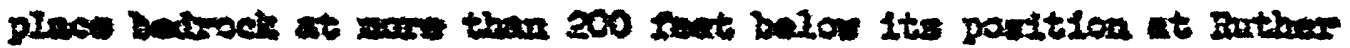

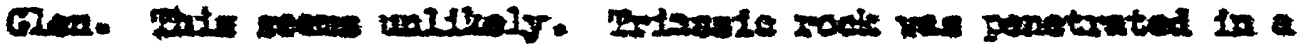

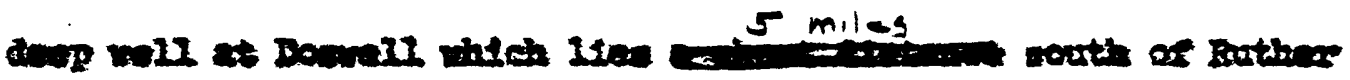

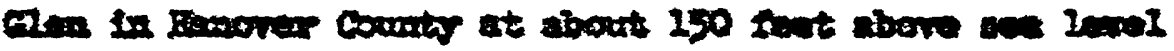
(Coturtara, 1957, 2. 78).

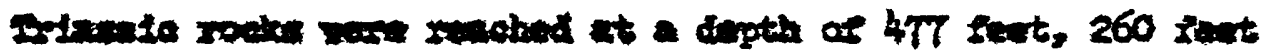

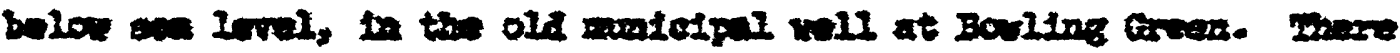

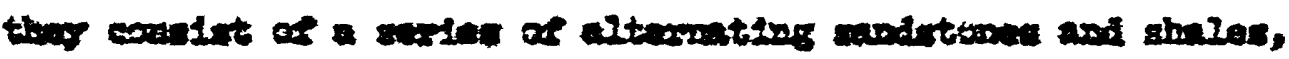

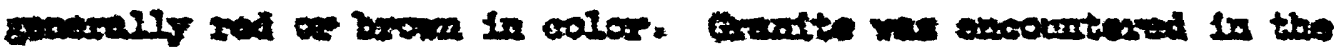

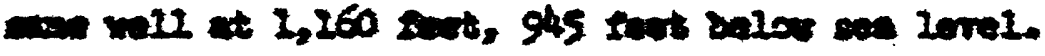

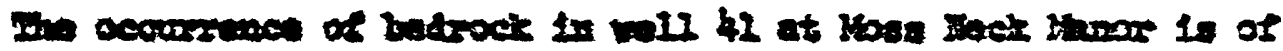

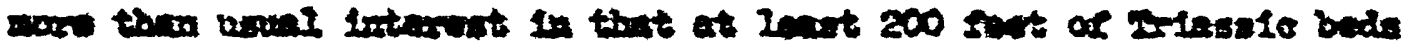

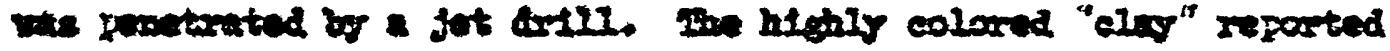

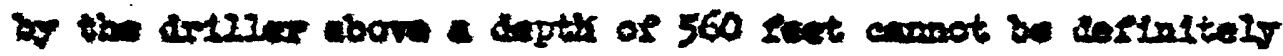

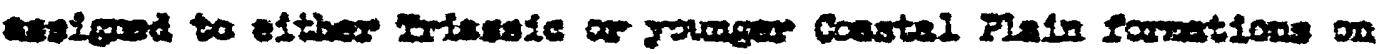


the busts of the decterption at band (aed 108,4), tabie 2 ).

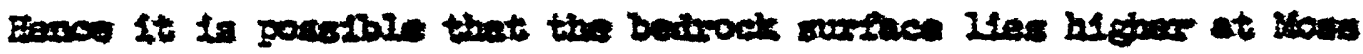

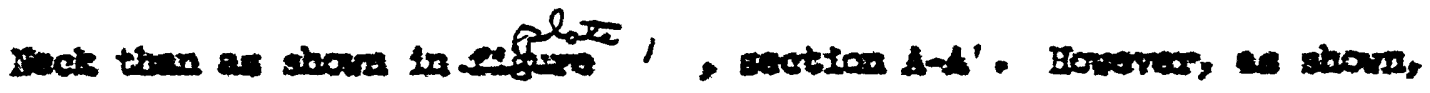

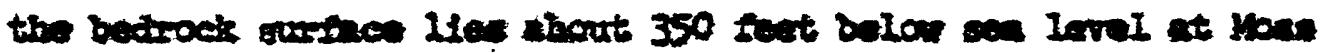

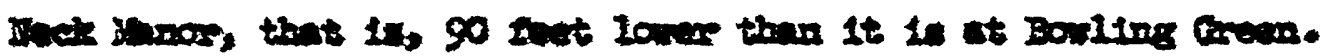

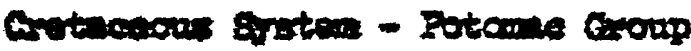

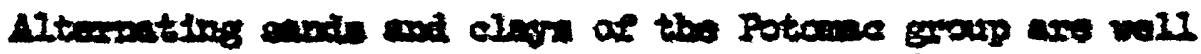

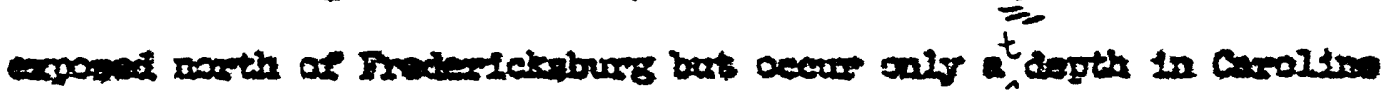

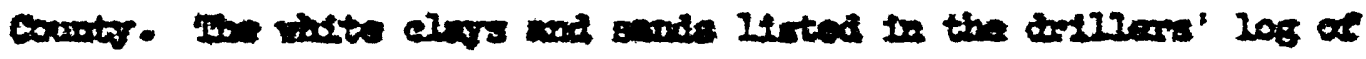
the dow wil (26) at Bowling arven between 365 and 477 seat ard

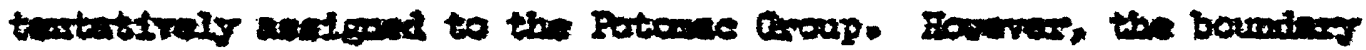

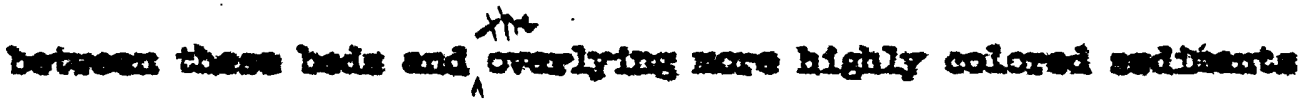

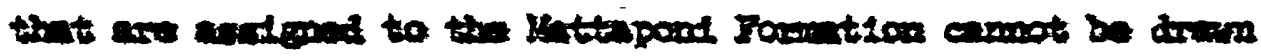
acouter.

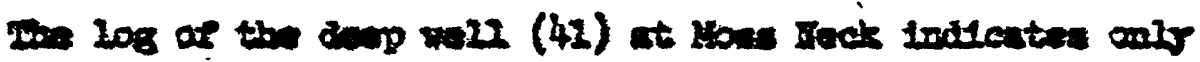

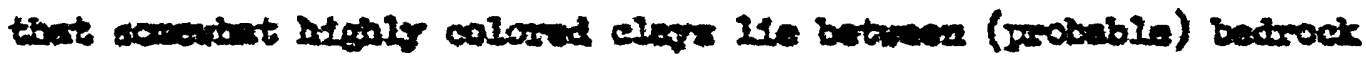

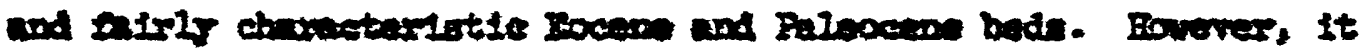

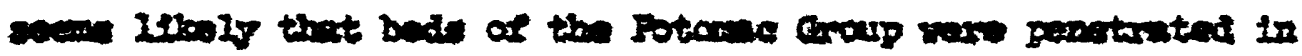

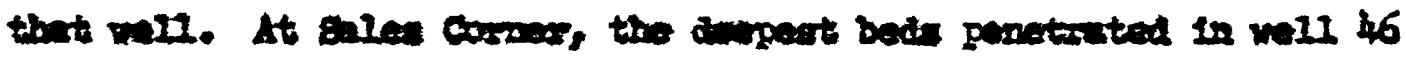

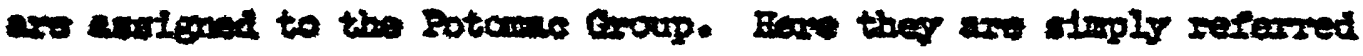

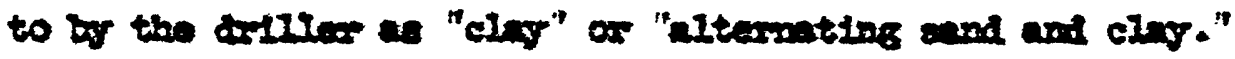

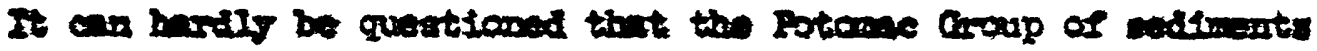

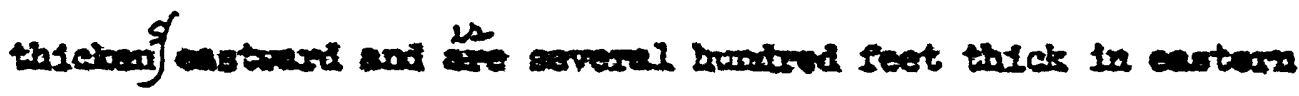
coroliso conts. 


\section{Cretaceous to Tertiary Systems}

Upper Cretaceous (and Paleocene Series, - Mattaponi Formation

The Mattaponi Formation of Paleocene Late Cretaceous/age;

characterized by highly colored mottled clays and glauconitic in places, is believed to be present as far west as Bowling Green. "Mottled blue and red clay" is reported at 15 to 46 feet below sea level in-wel-Im-22 $\left(22_{1}+t_{1} i_{0} 2 \mathrm{~J}\right.$

in the USO well, and "red, blue, and yellow clay" is reported at much the same depth in the old CCC camp well (23) $1 \frac{1}{2}$ miles east of Bowling Green.

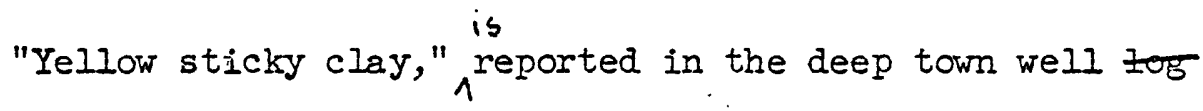
(16, table 2 ) from 9 to 70 feet below sea level. It may be noted that at Oak Grove, Westmoreland County, fossilferous glauconitic yellow clay of Aquia (?) (Paleocene) age was encountered in a well at about 200 feet below sea level. Yellow and yellow brown clays, with older indeterminate fossils (Cederstrom, 1945, p. 17, 1957, p. 19 and Sinnott, 1967), continue to about 500 feet below sea level. Returning to consideration of the Bowling Green well, yellow clay is reported as deep as 150 feet below sea level, thus suggesting that the Mrponi Formation is at least 140 feet thick.

At Moss Neck Manor (well 41) which is less than 2 miles east of Bowling Green, "mixed tan and white clay" at 130 feet below sea level should be part of the Mattaponi sequence. why? 


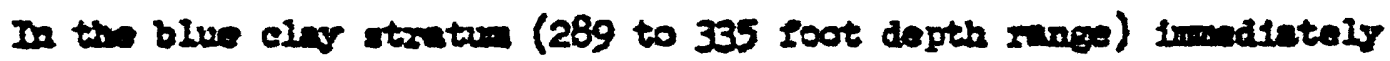

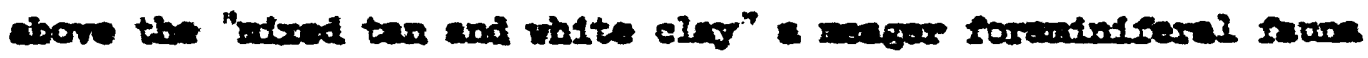
vas found that appears to be similar to the assamblage sound at 600 rute near Kilmarock. Hence the top of the Vattapont is pleced at the bace of the "stome" (probebly thin 21mertone and and strata) at a deptis of 289 feet which is 64 feet below sea Ierel.

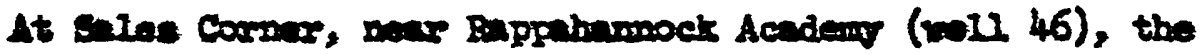
formtion is leas diatinctive. Blue clay reached at 106 seut belon sen Ievel probablo reprosente the Nattapont Fosmetion.

At Plowt Roval (well 53) blue elex penetrated at 159 feet belor

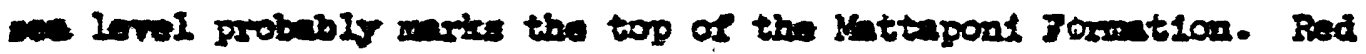

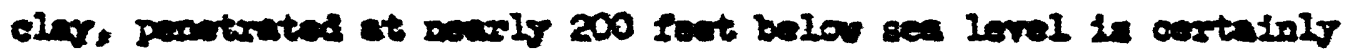

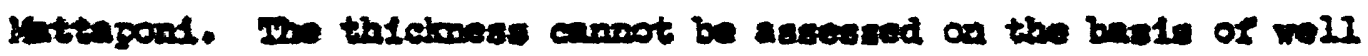

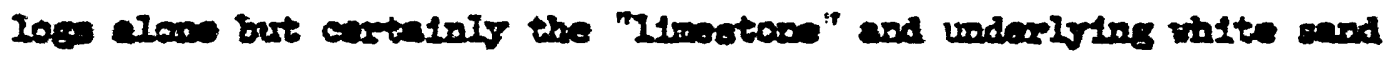

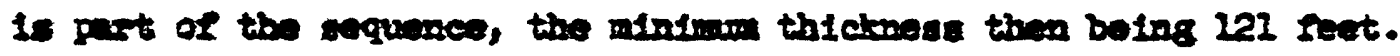

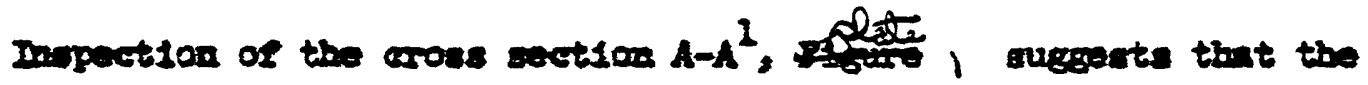
formation is mon thieter.

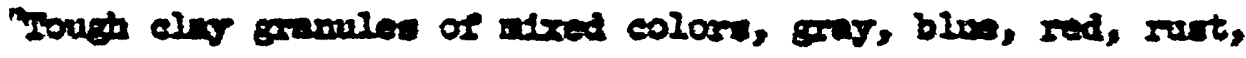

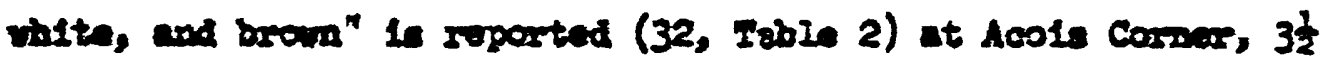
miles eart of Borling areen, at about 200 seet belon sea level. Provemablo overiring 21thologicalis leas distinctive wtrate that are senched by the drill at about 86 soet bolos sea level ahould 
also be areloped to the Kattapons. Sindlar bed were also reparted

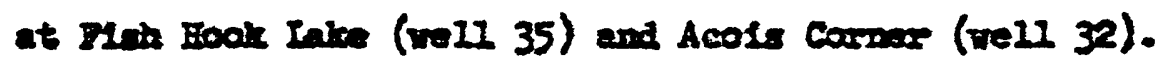

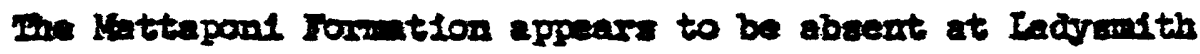

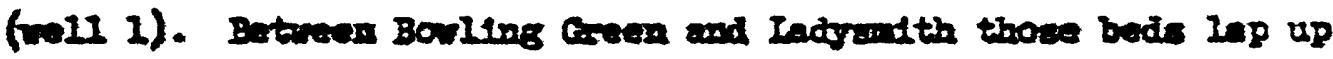

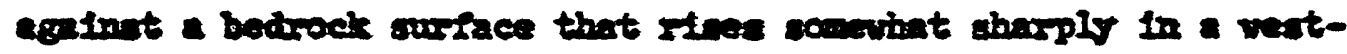

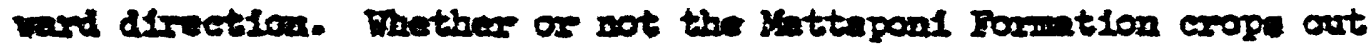
fuet abowe Ievel along the fiappahamocis in eastermont Spotopiranis county is jet to be deternined.

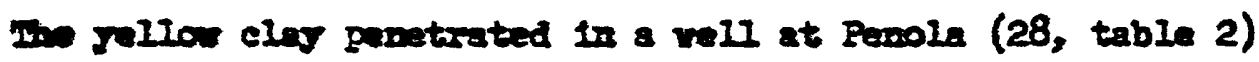
at 195 sect is probebly at os noar the top of the Mattapond section.

\section{seation 8yoten}

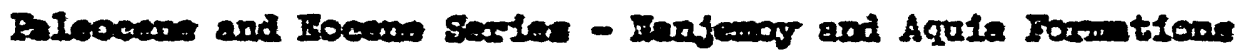

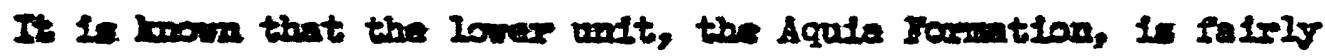
thick aloors the Fell Zow but thins out dowdip (Cedentirom, 1957, p. 24). The overiving sanjewos is relatively thin or aboent along the Fall zoos but thictom dowalp (wee woes rection A-A, pl. 1). the adraneing ranjeros 


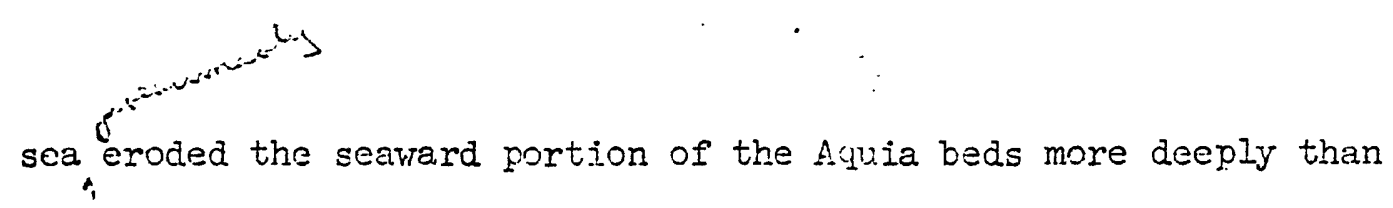

it did where that sea approached its shoreline somewhere west of the Fall Zone. In that siatively thick Nanjemoy beds were trom deposited upon the Faleocene (Mattaponi-Aquia) surface. In succeeding Niocene time another advancing sea transected the Nanjemoy beds (and any Late Eocene beds that may have overlain the Nanjemoy in Caroline County) but cut more and more deeply as it advanced westward coming to a previous slight seaward tilting of the Coastal Plain as a whole.

The base of the Aquia Formation can be estimated with a fair determination of degree of success from well logs at hand but the stratigraphic top of the Nanjemoy (base of the Miocene) is more difficult in this county than elsewhere ow wing to erosion of the higher beds and rather meager descriptions of the formations in some of the well logs at hand. As indicated above, no attempt is made to define the contact between the Nanjemoy and Aquia Formations.

the
Along ${ }_{1}$ Rhappahannock River, the Nanjemoy and Aquia Formations crop out the full length of the county. However, at higher elevations back from the river the Nanjemoy is overlain by beds of Miocene age.

At Port Royal the top of the Nanjemoy Formation may extend to about 50 feet above sea level and hence is not determinable from logs of wells there because they are situated on low $f \dot{f}$ sround. The base of the Aquia is considered to be the thin sand penetrated at 193 feet ( 159 feet beiow sea level), thus making the combined NanjemoyoAquia thickness a little over 200 feet thick. These 
combined formations ( maximum thickness here. The same thickness relationsnips have been shown to occur in the York-James Peninsula (Cederstrom, 1957, Slate 1).

At Sales Corner, a mile west of Rfpappahannock Academy, well 46 first encountered glauconitic beds at about 60 feet above sea level. The series of glauconitic beds and basal sands continue to about 106 feet below sea level. The combined Nanjemoy and Aquia fi......... are thus about 164 feet thick. This corresponds reasonably well * with findings at Dogue, a few miles to the northwest in King George County (Sinnott, 1967) where inspection of microffossils helped to establish the section with reasonable accuracy.

At Moss Neck Manor (well 41, table 2 ) slightly west of the Sales Corner locality, the Miocene-Eocene contact is arbitrarily placed at 80 feet above sea level. On that basis the combined Nanjemoy and Aquia Formations are about 160 feet thick.

Elsewhere in the county top of the Eocene is somewhat difficult to recognize from logs at hand. At Bowling Green a stratigraphic break is recorded in the log of well 22 at 80 feet above sea level. This is probably the contact between the Eocene and overlying Miocene beds. The Aquia, and possibly thin overlying Nanjemoy beds, appear to be 95 feet thick here, extending to 15 feet below sea level. Presumably it is at about that level in wells at Howards Corner (33), Acois Corner (32), Eubank Corner (34), and Fish Hook Lake (35). 


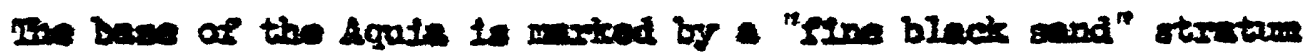

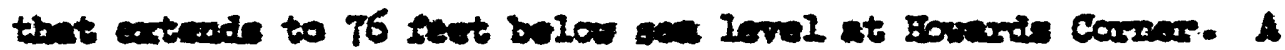

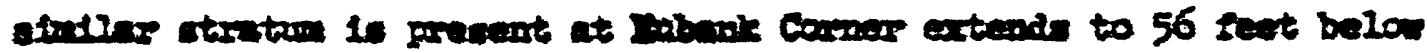

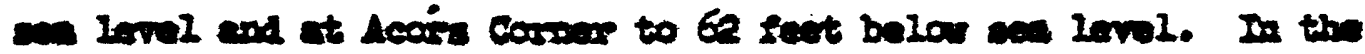
Intere two localitio the elnueonitie strutam is 89 and 120 thet thicts.

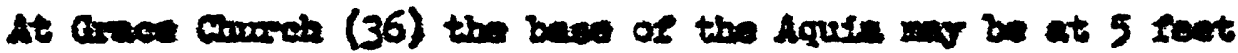

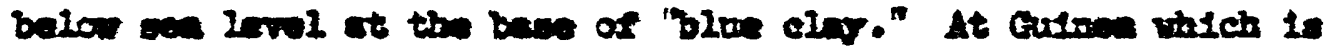

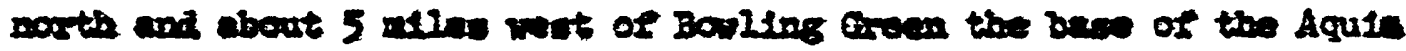

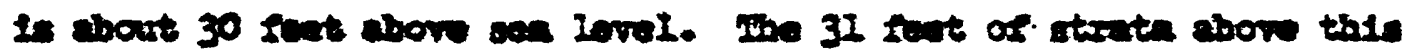

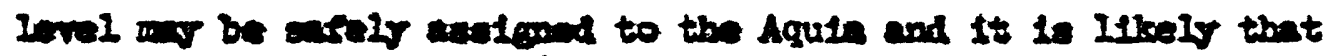

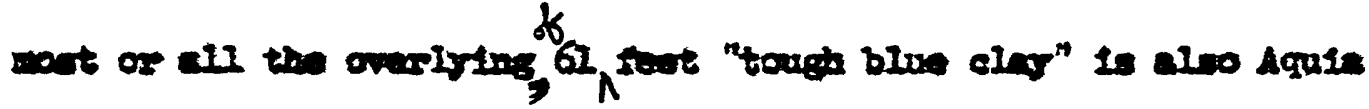

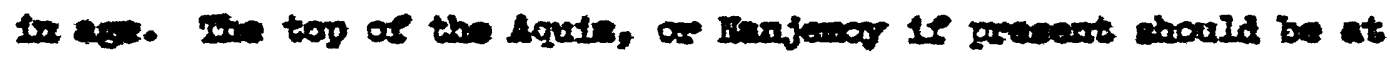

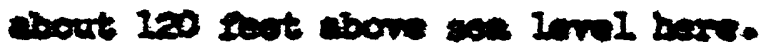

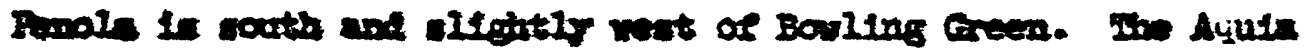

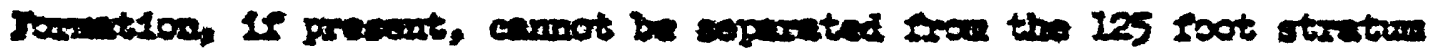
of Mlas werl" jocorded in the 208 of well 28.

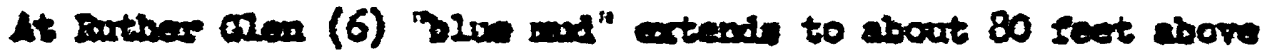

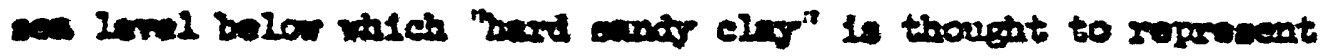

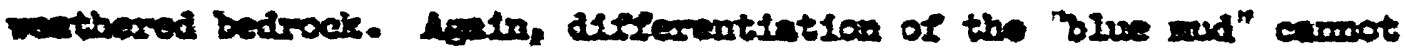
bo wale on the beste of the dath it but. 


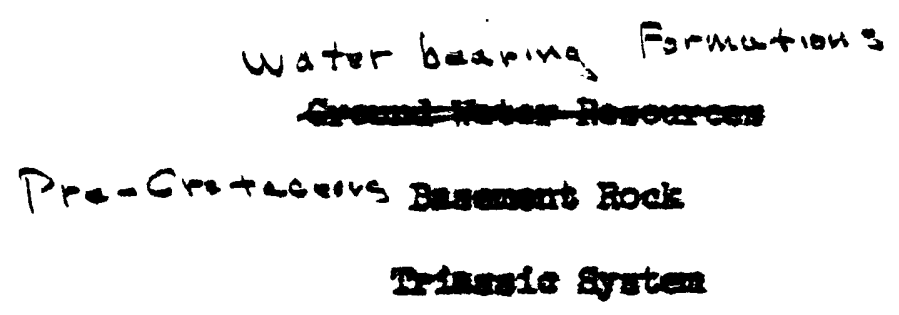

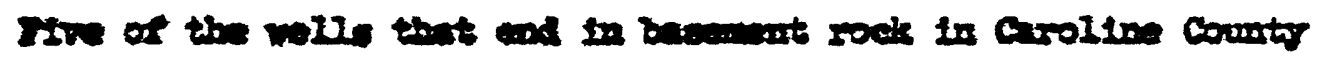

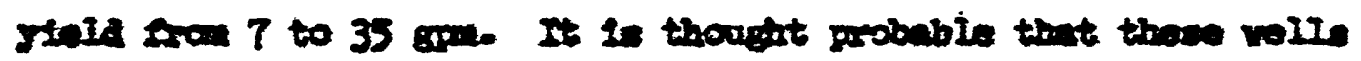

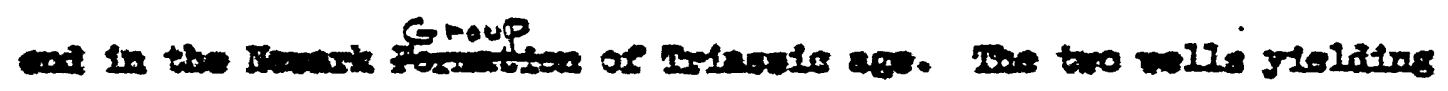
about 35 grom (1, 6, table J ) are arowad 300 fact deop. It it

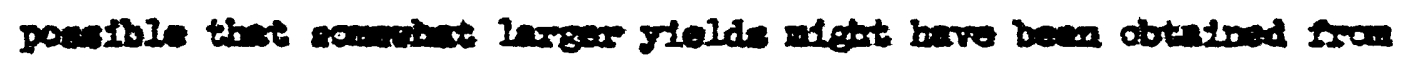

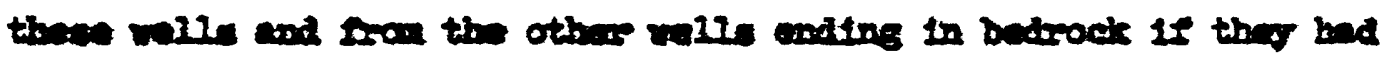
been contimed to depthe of 350 to 450 sent.

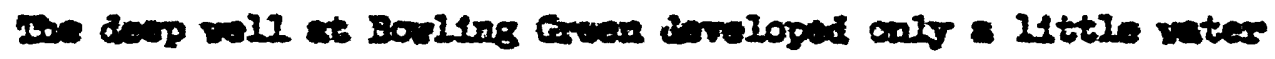

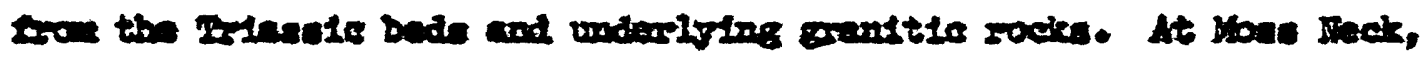

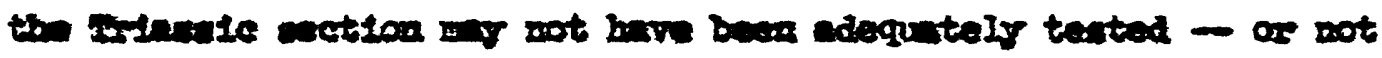

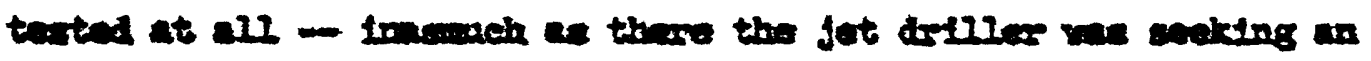
womolfdetad and sormation.

\section{antaceous aritum - Botane oroup}

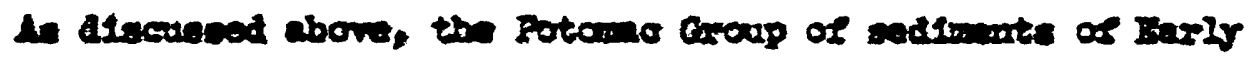

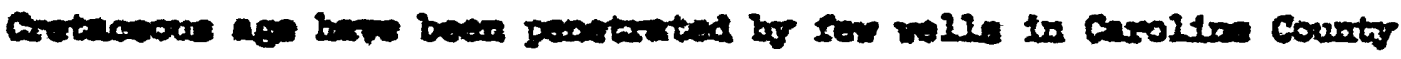

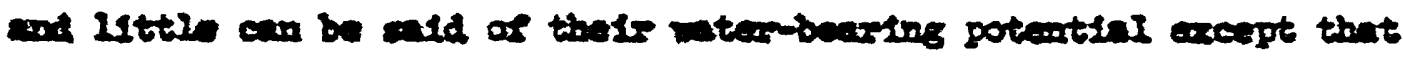
In the contrelel part of the county, as at Bonling arwen, thes do not appoar to be hiehlo procuctive.

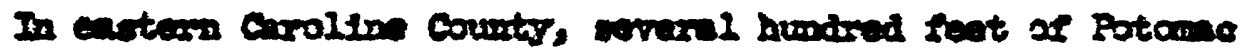

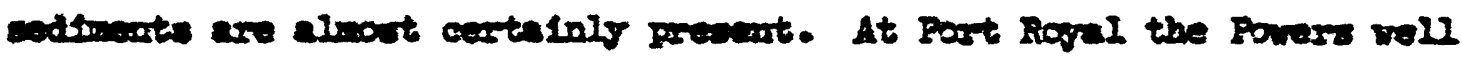

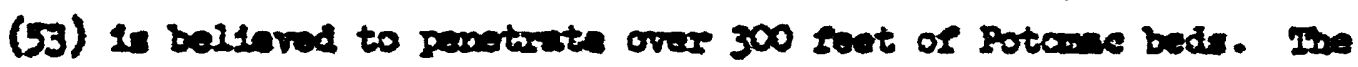
courtact butineen o 


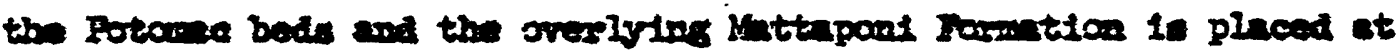

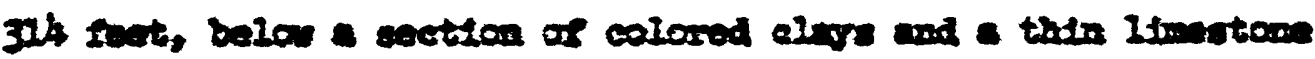

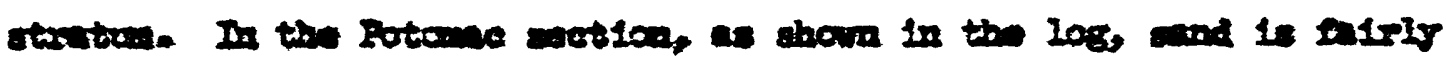

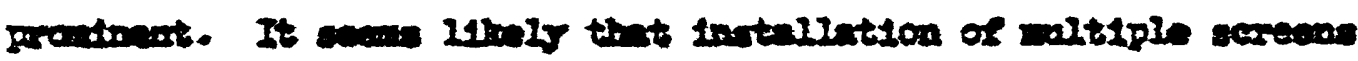

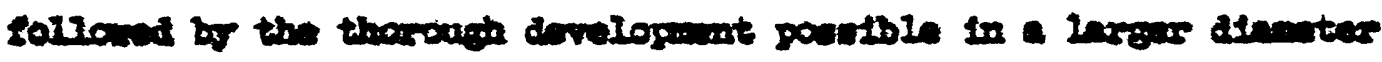

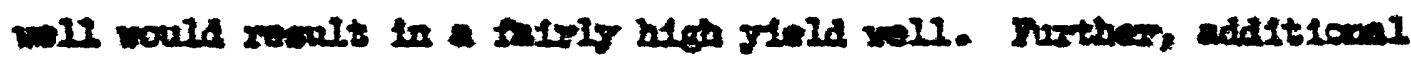

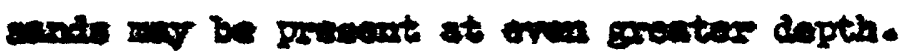

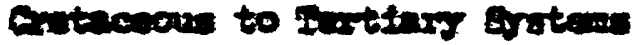

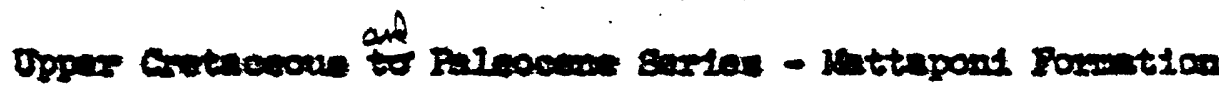

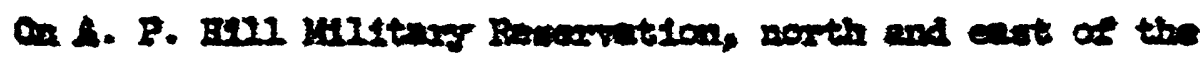

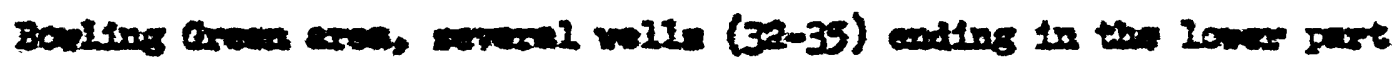

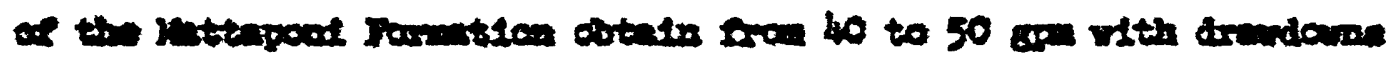

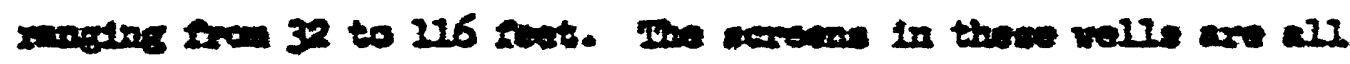

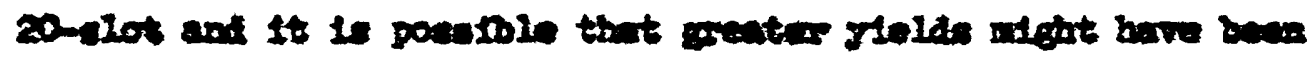

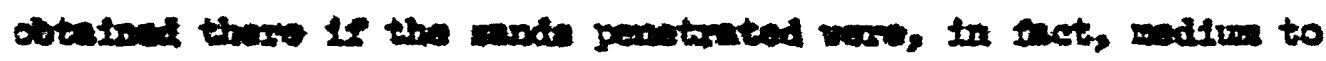

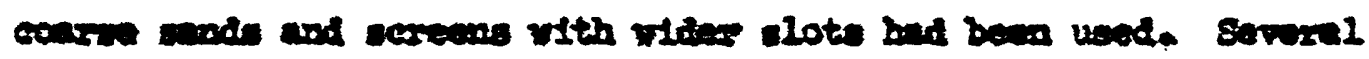

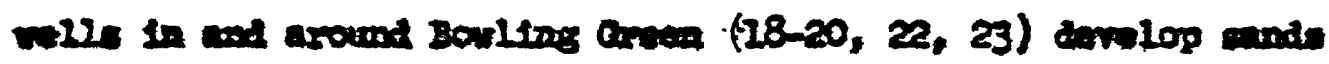

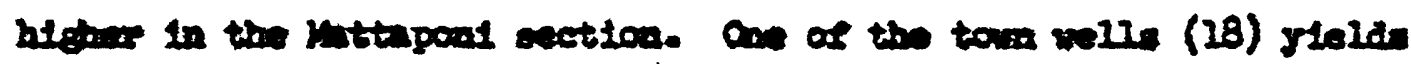

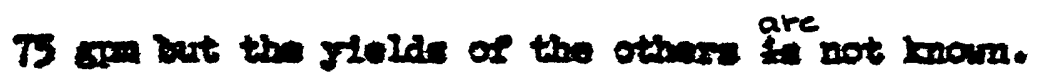

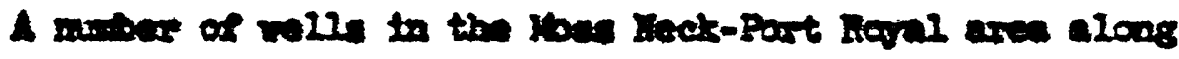

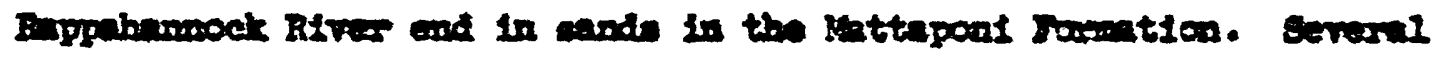
w110 are arowd 270 soot doop and an thought to end in the upper

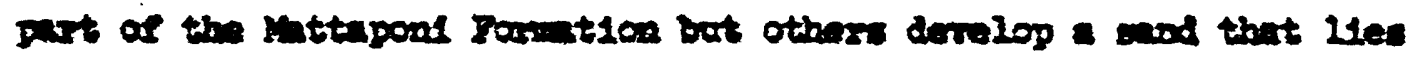

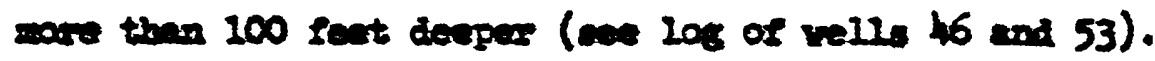




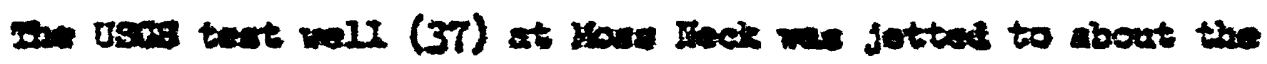

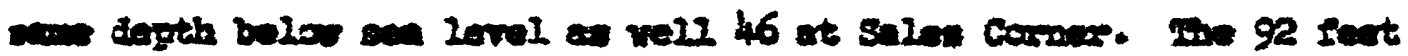

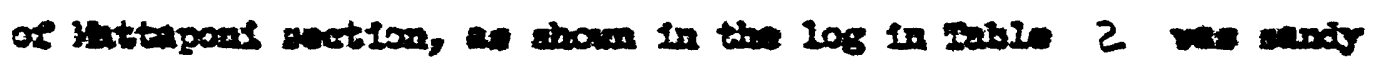

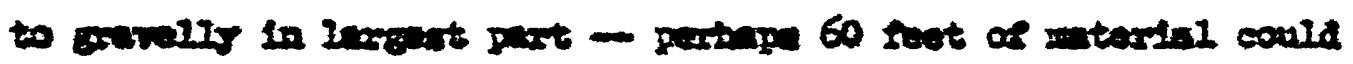

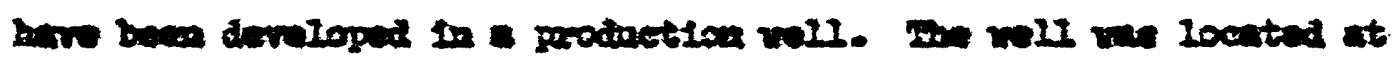
- elemition of about 20 soet above un level and had a flow or

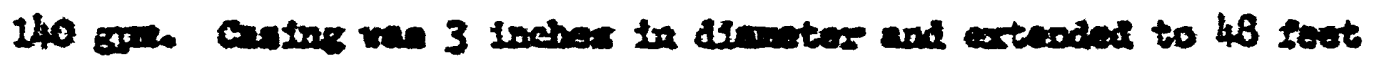

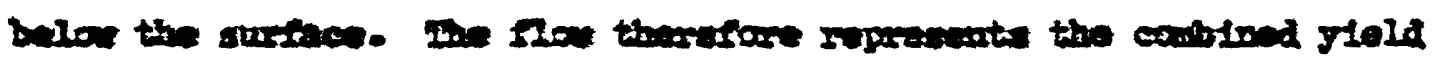
of all agutsers perentanted.

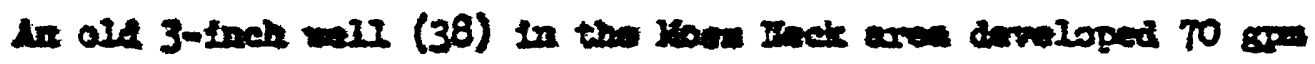

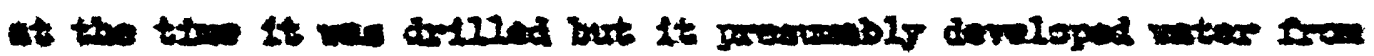

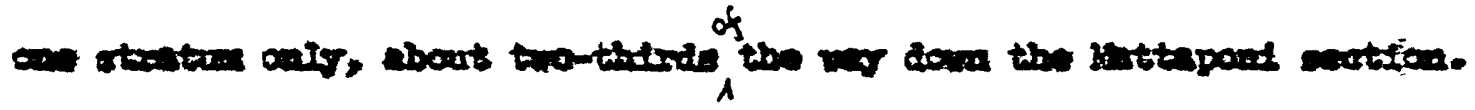




\section{Filecone Sariex - Aquin Fonnetion}

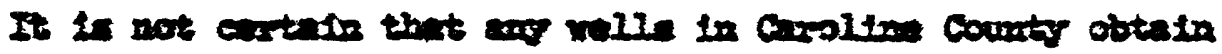

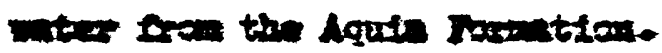

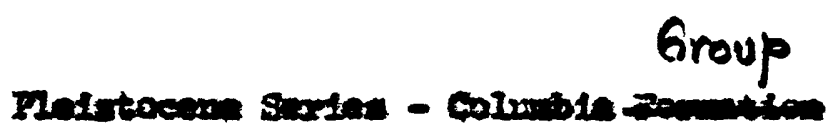

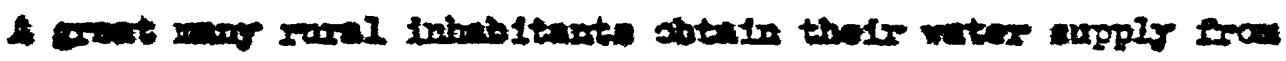

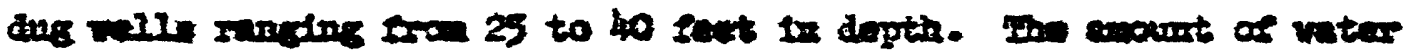

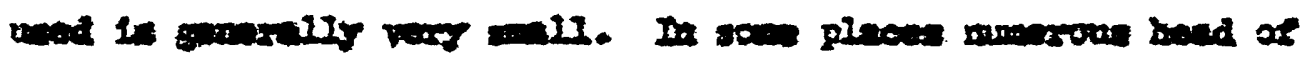

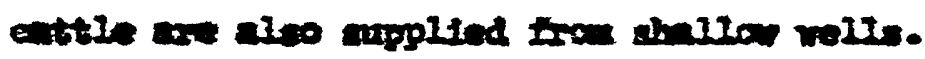

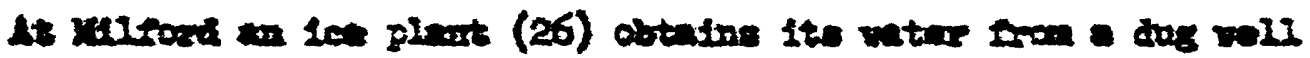

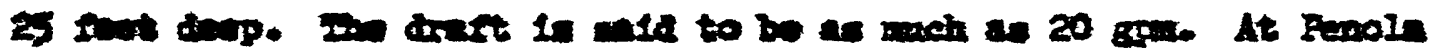

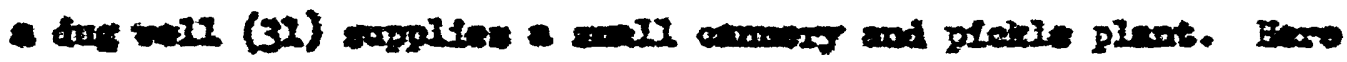

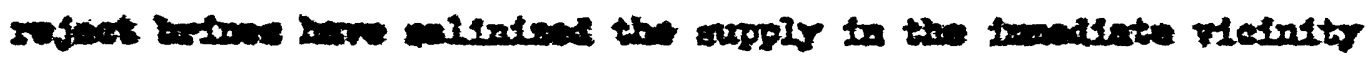
at the plinto.

\section{Qneste of Netros}




$$
\text { Quality = Natrir }
$$

Water in Coastal Plain formations enters those beds in the central and western part of the county but at first has only little opportunity to gain in dissolved mineral content. The entering rainwater and snow melt is slightly acidic to its carbon dioxide content and, being acidic, takes limy material into solution as it travels eastward and becomes hard. Hardness is present as calcium (and less magnesium) bicarbonate.

As the artesian waters percolate still farther eastward they come in contact with sediments having the capacity to exchange sodium for calcium, as a result of which the hard waters become softened although the total mineral content is essentially unchanged.

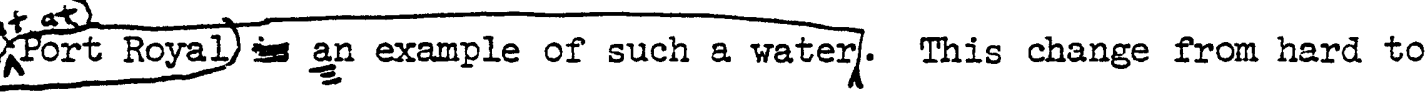
soft water is seen in the difference between samples taken from the area of recharge $(9,13,3 t$, table 3 ) and the sample from Port Royal (52). Those near the area of recharge are somewhat hard and, as seen from the high bicarbonate, have already undergone some base exchange. These waters, then, are sodium-calcium bicarbonate waters. At Port Royal deep Coastal Plain water is extremely soft but somewhat high in sodium bicarbonate. As is characteristic of water from artesian aquifers in the Coastal Plain south of Middle Peninsula, the concentration of sulfate does not increase much to breakdown of that constituent by biochemical action (Cederstrom, 19i $\frac{b}{6}(2.9)$. Waters from wells 44 and 48 at Rappahannock Academy are most unusual. Water from artesian aquifers that is both very hard and 
high in sulfate ( 162 min in the sample from well 48) are unknown in the York-James Peninsula and in the Coastal Plain south of James River. A sample from Fairview Beach (Sinnott, 1967) from a relatively shallow artesian well is of this type, however, and contains

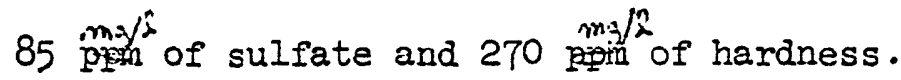

It is thought that the hard high sulfate artesian waters may have been derived from local recharge near Rappahannock and Potomac Rivers. In passing through the fairly permeable Eocene beds that crop out for some distance downstream from the Fall Zone, these waters gain more dissolved mineral content than those waters entering older artesian aquifers along the Fall Zone. Having traveled a much shorter distance, they have not had much time to become softened by base exchange nor has the sulfate be broken down by biochemical action. Most of the waters from deep wells are only moderately mineralized and are excellent for domestic purposes. The harder waters should be quite suitable for irrigation but the very soft sodiumbicarbonate waters present in the lower part of the county are considered quite unsuitable for that purpose. The very hard waters found 'at Rappahannock Academy are somewhat troublesome in domestic usage,

Only one sample is at hand from a well that obtains water from bedrock ( 3 , table 3 ). It is a somewhat hard bicarbonate water. Hardness is $99 \mathrm{mg} / \mathrm{i}$ :

Some partial analyses of waters from wells dug in the terrace formations are at hand, but are not given in Table 3 . They range in hardness from 18 to 78 rivg $/ 2$ although only two out of 9 samples 
bave more than $50 \mathrm{mg} / \mathrm{I}$ hardness. Blcarbonate ranges 8 to $86 \mathrm{mg} / \mathrm{I}$ in sensples at band although it is more camonoly legs than $50 \mathrm{mg} / \mathrm{I}$. Otber const1tuents are Lor. A Itr sanples contaln as much as $17 \mathrm{mg} / \mathrm{l}$ of nitrate, sugsesting that organle poliution way be present.

4 sample rrom a vell (31, mbie 3 ) contantated by veste brines fran a Elckie piant now Penola contalned 1,500 ag/ $/ 1$ of chlorlde and bed a bardness of $216 \mathrm{mg} / 2$. 
Tuble 2 --Ioge of velle in Caroline County, Va. Lestuty)

will 16, Musiefpelity, Bowing brem

(Log sydnor Pump and well Co.)

Altitude 215 reet

$\begin{array}{ll}\text { Depth } \\ \text { (foot) } & \text { (feet) }\end{array}$

Lot dencoribed

209

209

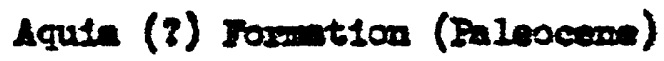

sand; water

4

213

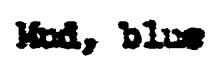

3

216

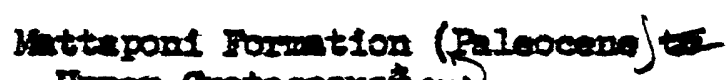

Opper Cretaceougta and

Cor, valte. 8

8224

ars, selios

2

226

Cor.

6

232

ent. 3ellor

53

285

erer, white

17

302

sandoton; \& 11tile rater

6

308

Clor, wite and rellor interbedided

Potome (8) Group (I0wer Grataceous)

Burpan

Sand, veter

Crov, wite

sand

Cov, wite

Sand
2

$T$

1

16

3

17
367

374

375

391

394

412 


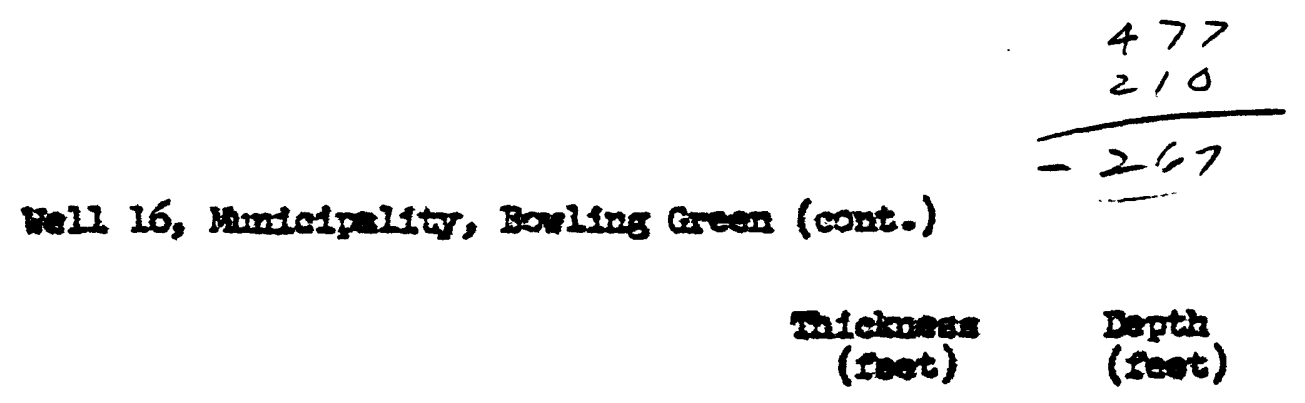

Giv, with

$4 \pi$

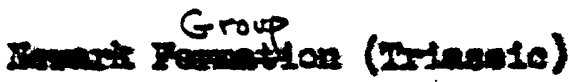

Endintom

3

480

Oins, notte

20

500

sind

8

508

Ora, whe

25

533

sunietcres, brows

15

548

sand, ned

12

560

Budutows, Brown

843

ewo ("ablel)

1

84

suidutaps, browe

32

875

Cor ("abien") and interbedied ondones

63

938

ero ("inele"), sed

2

9to

sompertose

1

942

sunditons, brans

9

950

on ("solol"), 2ed

4

954

sundstome, and and

38

992

Cus ("abele"), ando

2

99

sunintons, brown

6

1,000

sundoce, white, vater

3

1,003

vad

1

$1, \infty, \infty$

Bandetom, brown, wite and gras 
Well 26, Muntefpalsty, Bawling Green (cont.)

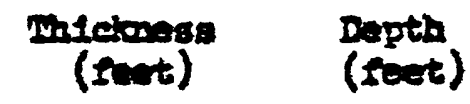

stat

$\begin{array}{ll}1 & 1,089 \\ 41 & 1,130 \\ 30 & 1,260\end{array}$

Preftumian (3)

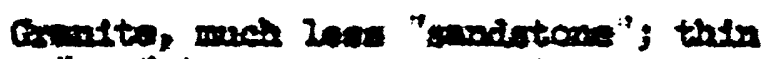
"mad" levers at interinis to 1,402 font. A des creviea repostad at 1,480 reot and a crovice with ecos vatare at 1,509 soot. 
Table 2 . Log of vells in Garolibe County, Ma. (cont.)

Woll 22, Uso Houre; Bowling Geon

Altiturde 200 foet

Thicleness Dopth

(fent) (feet)

Columbin aroup (Fle1stocera)

cons and and, gollow

To

To

cuenapenke Group (Miocene)

mol, blue

To

140

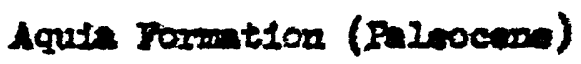

vers, blus, balle

95

235

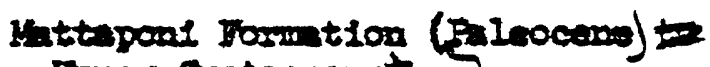

Oppese crotaceountions

aro, moteled blue and red

$31 \quad 266$

and

19

283

S1It

30

315

suod, wadium texture; vater

40

355 


\section{Imble 2 . Ioge of welle in Caroline County, Va. (cont.) DeII 28, De. I. I. Hoad, Panola \\ (Log tram Va. Dept. Minowi Babowrees flles) \\ Alttude 202 fret}

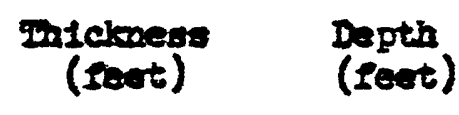

Columbia Gaup (Pledotocene)

Sand

25

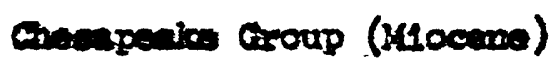

ary, sellow

45

70

ondiserentinted

Harl, blue 125

Giv. 7210

41

236

C19. barom

89

265

Ende aly, borm

32

297

end, consea and cly, and

11

308 
mable 2 . - Ioge of wells in caroline county, Va. (cont.) De2l 32, A. P. H4ll Militarg Reservation, Acols Corsers Altitorde 278 peet

Thelones

(root)

Dopth

(feat)

Dodeneribed

61

61

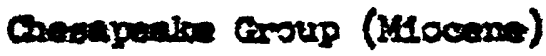

Clov, blum-gras

81

142

Aquth Forintion (Finocane)

Sind, clinucoulte, IIne, abell

Anguratar, elayes

110

252

sind, flos to ndilu; ratert

11

263

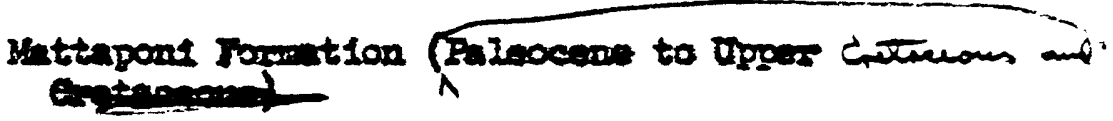

Cins, tough eramules, grag, blos,

201, suat, whste, and brow

58

321

Undenentbes

87

408

8ant, natese

22

430 
Table 2 .--loge of wells in Caroline County, Va. (cont.) DII 35, A. P. B11I Militasy Reservation, Fish Book Iaks Altitude $\mathrm{giv}^{5}$ feet

$$
\begin{aligned}
& \text { Thicloness } \\
& \text { (feet) }
\end{aligned}
$$

Colvmis Group (Plelatocone)

Cror, sandy

20

sand, conrese and pee gravel

61

81

Creanpeaise Group (Mtocene)

$$
\text { Ciny, blow-gow }
$$

Fonjemor and Aquia Formation

(Bocene and Paleocinne)

Cies, blum-gras

Mittapons rormation (

Ciry, tough, granules, varfous colors

gand, nediven, eleros

102

552

Cis, ext 
mable - - Iog of wells in caroline county, Me. (cont.)

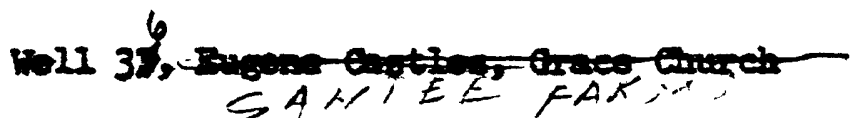

Aititude 190 toot

$\begin{array}{ll}\text { Denfolosess } & \text { Depth } \\ \text { (seot) } & \text { (foet) }\end{array}$

Columbir Group (Pleletocena)

Sol1

32

32

sund, Jellow

9

42

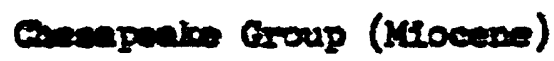

Gro, Bus

Aquets pormation (Filoocene)

er, blue

$-220$

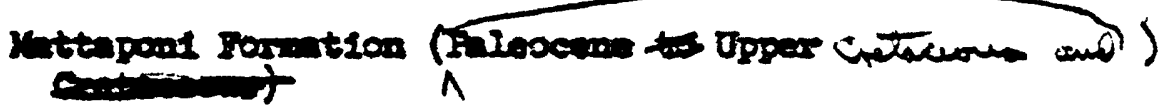

\begin{tabular}{|c|c|}
\hline Clor, hard, and grevel & 8 \\
\hline an, blos & 15 \\
\hline Clar, brom & 22 \\
\hline Cory and sand & 5 \\
\hline Sand and eravel; vater & 12 \\
\hline
\end{tabular}


Table .--Logs of wells in Caroline County, Va. (cont.)

Well 41, T. V. Houser, Moss Neck Manor

Altitude 205 leet

Thickness

(ieet)
Depth

(feet)

Columbia Group (Pleistocene)

Clay, yellow

Chesapeake Group (Miocene)

Clay, blue

Nanjemoy and Aquia Formations

(Eo,cene and Paleocene)

Clay, blue

35

160

Sand and shells

5

165

Clay, blue' ?

97

262

Stone

27

289

Mettaponi Formation Paleocene

Upper Cretaceoust and?)

Clay, blue

46

335

Clay, mixed tan and white

10

345

Clay, brown to red

27

372

Undifferentiated

Clay, hard, tan to red

118

490

Clay, hard, sandy, tan to white

45

535

Clay, red

25

560

Newark (Triassic)

Clay, hard, $\tan$ to yellow

40

600

Stone

4

604 
Mell 41, T. V. Hourer, Mowe Heck Mnnor (cont.)

Driclonops Depth
(foot)

Burd formetion, tan

34

638

stow, woderstely berd

14

652

sompatose (bard elevi, sbalat)

10

662

Burd formation, white

3

665

stons

20

685

End formotion, tan

30

715

semiation, bard

10

Tes

Stoms, modesately bard to bard

28

533 
male 2 .-Ioge of velis in curoline Counts, Pa. (cont.)

Dell 46, A. P. B1Il utlitary Beservation, Sales Corser

(IOS D. J. Coderstrom and I. W. Yoongquint)

Altitude 205 seet

incleineses

(feet)

Depth

(feet)

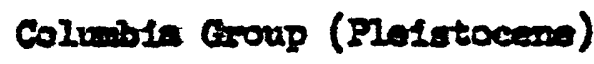

Cin and and

31

31

Cremapention croup (Mlocesed)

ener, blue

101

132

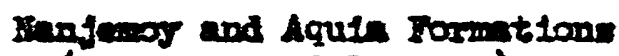

(Bocuen and Paleocene)

Verl, and, elemesontie,

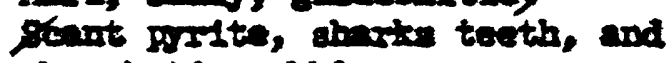
phouphutic pobblea

25

247

smers.

$\frac{1}{2}$

1472

Ciro, bive, treee of ginuconfte

6

154

Gro, ginueonitie

4

158

Cis, berd

논

$158 \frac{1}{2}$

ONer, blu, trace of ginucoutte, - Ior shello

$32 \frac{1}{2}$

190

Mrs, blw, sufotis glaveondtie

10

200

Civ, blue, trace of glauconste,

- fiver shell.

9

290

CIN, blue, glauconitle

3

send, guartz, conrse

3

293 296 
Well 46, A. P. B1II yilitary Beservation, Salee Conper (cont.) ons clonege

(fest)

Depth

(feet)

Mattapons Formation (Flescene to Upper Cretaceores)

Ory, blow, trace of gleuconste

Cunvel, medium texture, vater

15

Cing, silto, gros

23

311

Civ, atity, to sod

37

334

sand, quarts, Ifles, wator

18

37

Sand, quarts, modilum, vaters

389

10

426

436

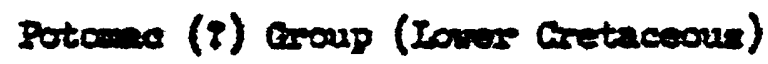

arer

Mer and sand, alterontiog
6

26
442

450

$\leftarrow K^{2}$

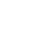

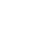


Trble .-Loge or valle in Crroline County, Ve. (cont.)

Mell 53, 17. T. Powers, Port Royal

Alt1tore 34 reat

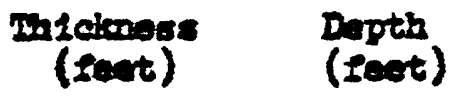

Columible Group (Rlalutoceno)

So11

30

30

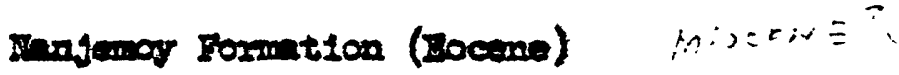

Cley, blve ("rock" ruported at

52 and at 63 peot in an

offrout rali)

Mifiti

70

100

8nd, Eleucensto

$\frac{1}{2} \quad 200 \frac{1}{2}$

Aquin Formation (Firiocean)

An, blue (A thlak bed of burd shelle 254 to 174 sent and e glauconste bod; at 167 feat in raported in adjacunt

Enad, whtte

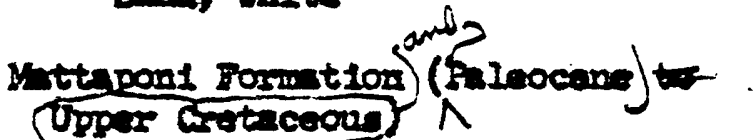

GD, blow

A19, 20d, cormis

Civ, brown

End, vitte

CIr, compmet, undy

Intentase

gund, wite

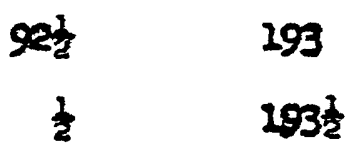

$46 \frac{2}{2} \quad \therefore 0$

$5 \quad 245$

$24 \quad 269$

$4 \quad 273$

$22 \quad 295$

$4 \quad 299$

15

324

92 
Dell 53, พ. T. Poweres, Port Boyal (cout.)

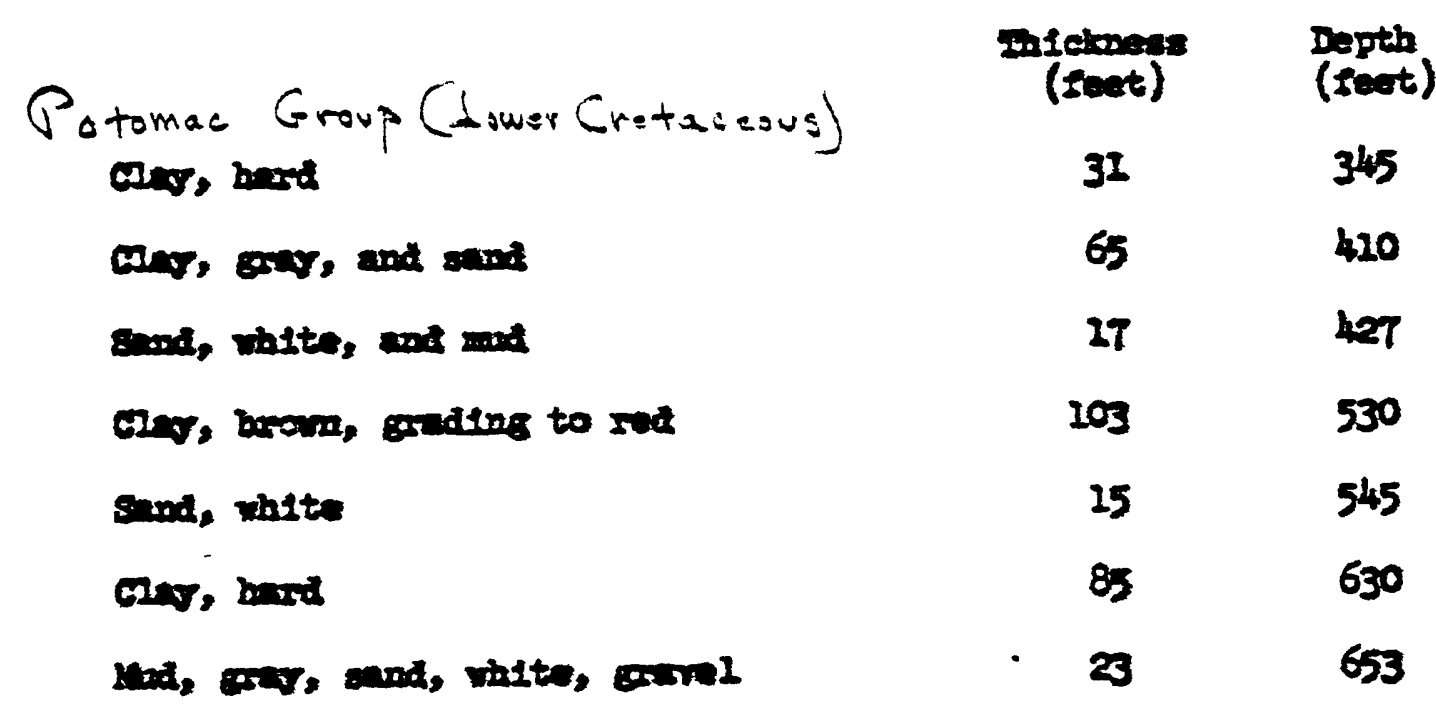




\section{Essex County}

Essex County lies along the south bank of Rappahannock River southeast of Caroline County and wholly within the Coastal Plain Province. It has an area of 258 square miles and a population of 7,776 of whom $i, 086$ reside in Tappahannock.

Rural farm population declined from 45 percent to 26 percent in the 1950-60 decade and in 1960 agricultural employment accounted for only about 15 percent of the total employment. There are 24 manufacturing establishments in the county, most of which are small and produce lumber or wood products but two rather large fabric plants are located in Tappahannock. Almost two-thirds of the farm income is obtained from sale of field crops, chiefly soybeans, corn and wheat and almost one-third from livestock. The value of standing timber and poultry products sold is about 10 percent of the total farm income.

A number of points of historical interest, largely pertaining to colonial Virginia are found in Essex County, as a result of which there is some tourist trade.

U.S. Highway 17 traverses the county parallel to Rappahannock River connecting Tappahannock with Fredericksburg and U.S. 360 leads into Tappahannock from Richmond and across the bridge at Tappahannock. to the Northern Neck counties. No railroads serve the county but bus service is available. Tappahannock is and has been since early colonial time a river port and the Rappahannock River still serves as an important transportation route for bulk shipping. 
角

-A municipal airport is located at Tappahannock.

An accredited college preparatory school for girls is located at Tappahannock. 


\section{Cosogr}

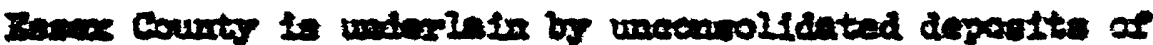

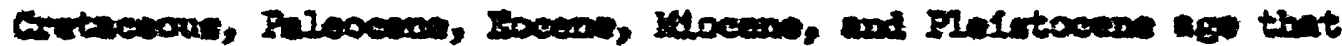
$(3)$

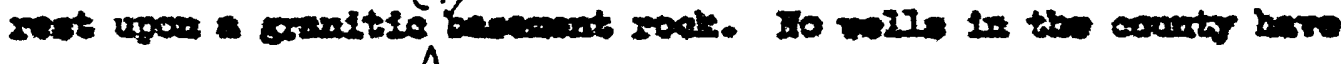

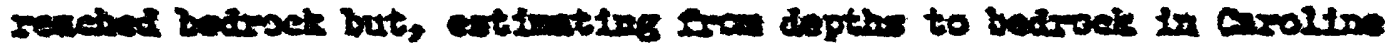

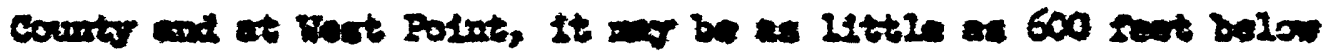

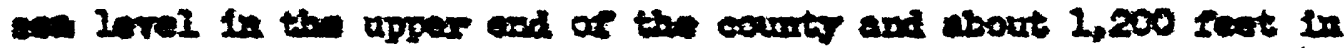
the lowe part of the eoruth.

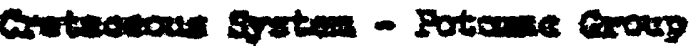

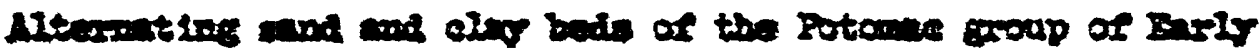

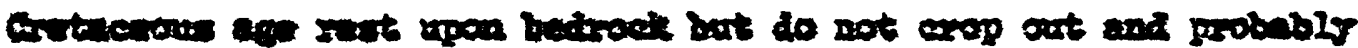

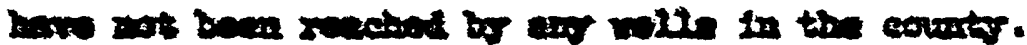

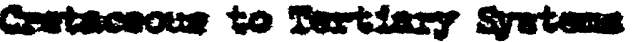

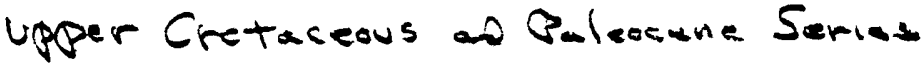

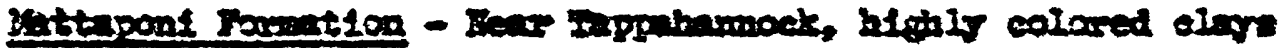

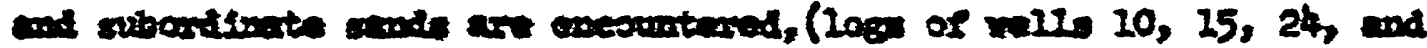

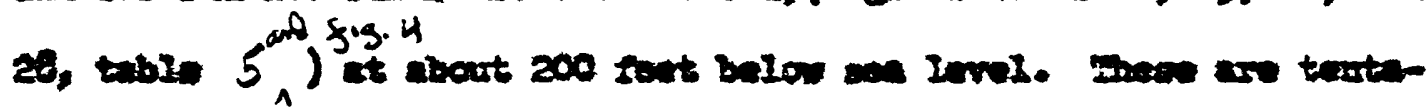

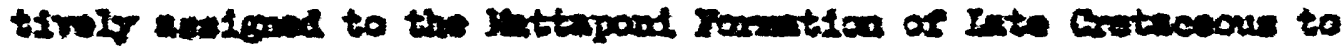
Baleogen now

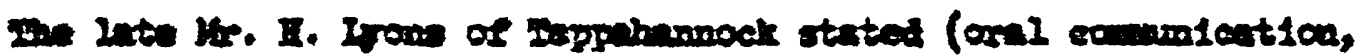

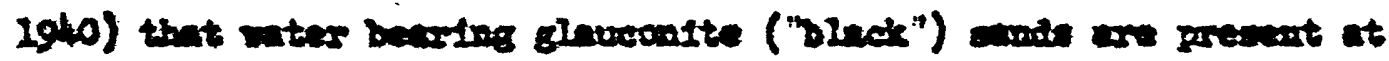

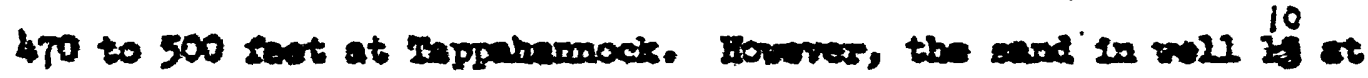

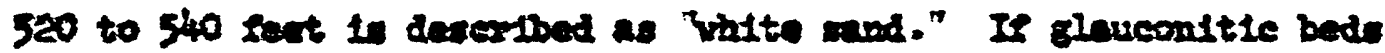



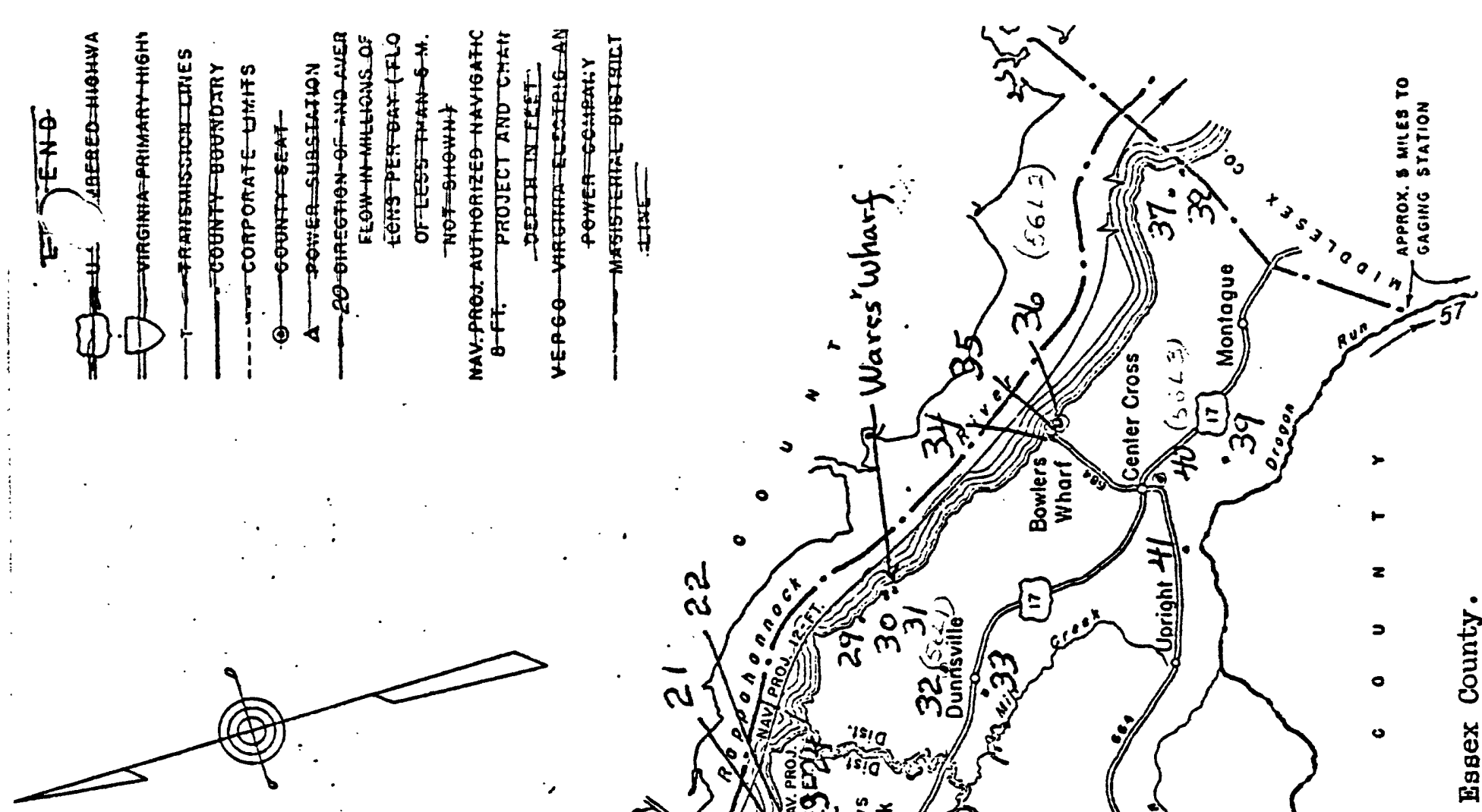

is

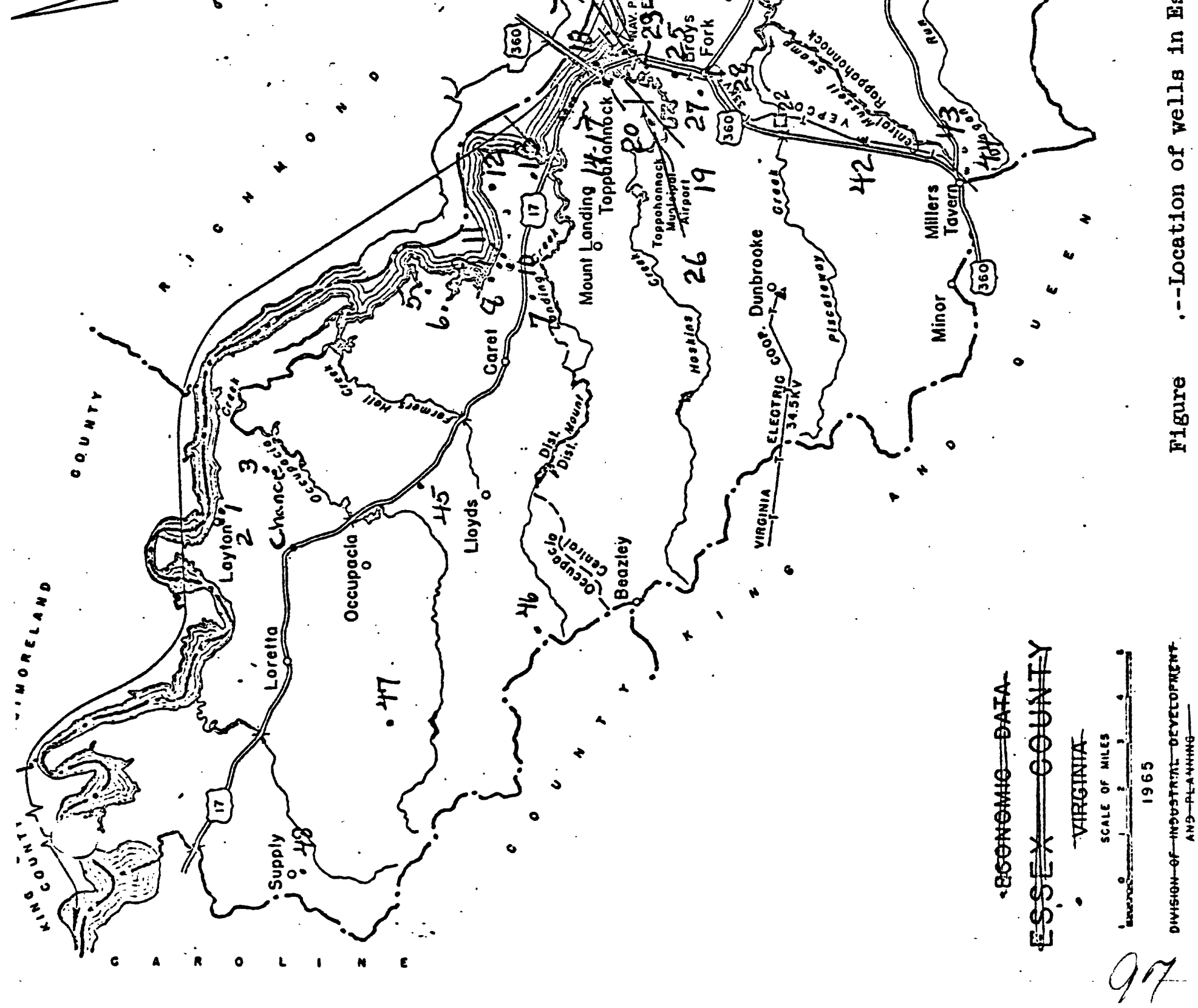




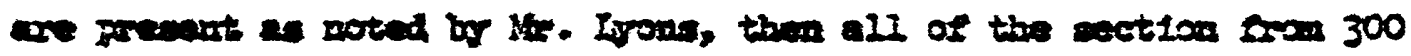

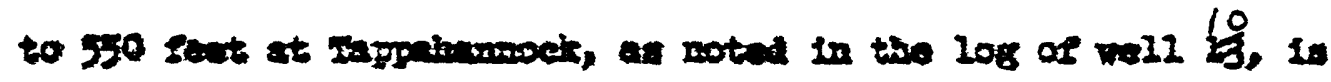

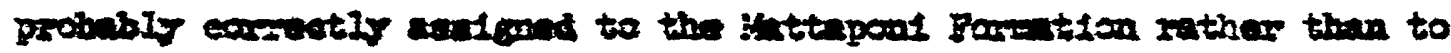

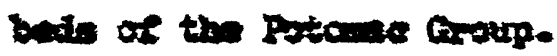


Essex

$$
\text { A lol- foot stratum of }
$$

$\Lambda$ Elack sand is reported to extend to about 370 feet below sea level in the Clanton well (26) at Tappahannock, more than 250 feet below the Miocene-Eocene contact. The lower portion of this stratum fhould most likely be assigned to the Mattaponi.

A rereproblem-is the brown or red clay penetrated at about 240 feet below sea level (about 150 feet below the Miocene contact) in wells $10,13,15,35$, and 36 in and around Tappahannock appears to be too low in the section to be the Marlboro clayx Memkar the basal member of the Nanjemoy Formation. In any event the Marlboro clay in its typical development is pink rather than brown $\equiv$ or red. Hence, it seems likely that this clay marks the top of the Mattaponi Formation and probably correlative (to the extent that correlations are possible in Coastal Plain sediments) with the first colored clays penetrated at Port Royal upstream.

Downstream from Tappahannock tan and red clays are first penetrated at about 240 feet below the surface in well 32 at Dunnsville. Aquia Formation - The Aquia Formation, is of Paleocene age. However, Aquia strata containing fossils similar to the outcroppings on Aquia Creek, although of Paleocene age, can be differentiated from the underlying Mattaponi Formation. Studies elsewhere (Cederstrom, 1957) show that the typical Aquia of the outcrop zone thins out downdip. Thus it would be expected that at Tappehannock the Aquia Formation would not be very thick, perhaps only 10 feet or so, but thicker in the upper part of the county and probably absent a a few miles downstream. 
Textiaxy Syaten

Iocoun Serples

Enefenor Foriation - As shom on the log, table 5, glauconttic

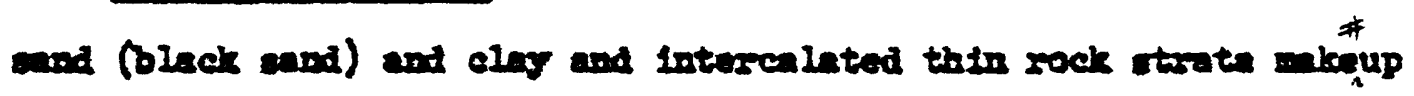

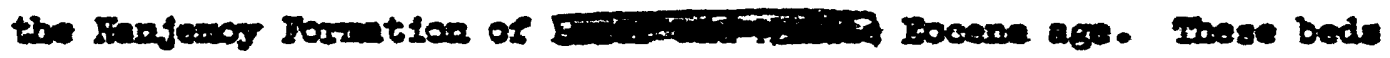

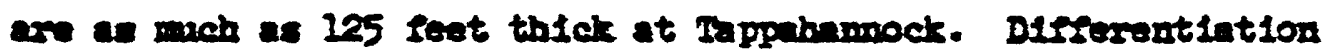

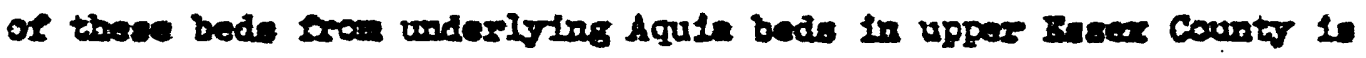

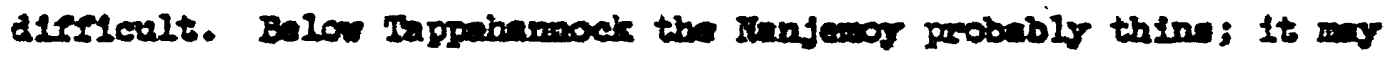
not catend as far eastinard as thbama.

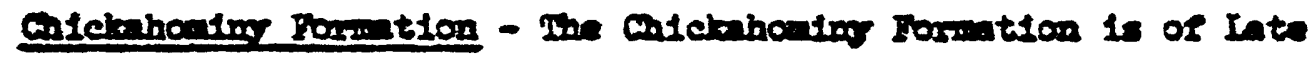

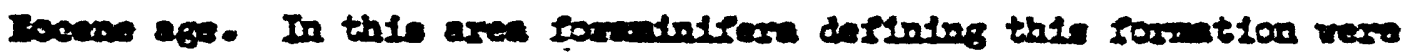
secogntred at a depth of 120 feat below ea level in a vell at cat

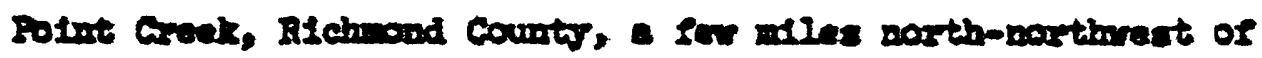
Inpahnmock. The forwation thin out updip and doen not approach the FeII zow and it probubly is not present in the upper part of the county. The thiclowes of the Culabenoming in and around

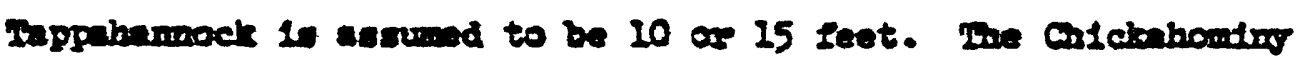

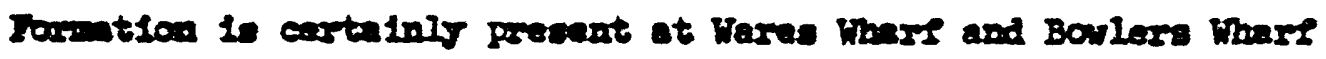
vbers "black ande" and "Dlnck and white sands" are roported Inndiately below nopdewcrlpt Mlocune mele. It is, therefore, asound that the Culctahoutwy formation is about as thict there as It if in conparable arvas in the Yost-jamos Pentroula. Thus in

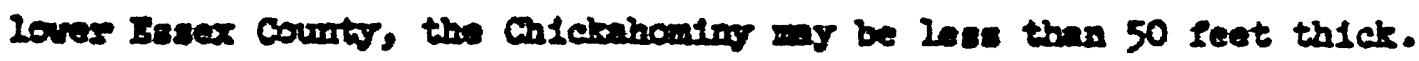




\section{Chese Peakin Group - \\ 3toonen sented}

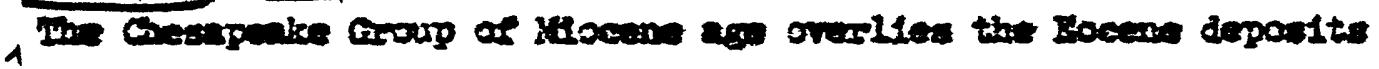

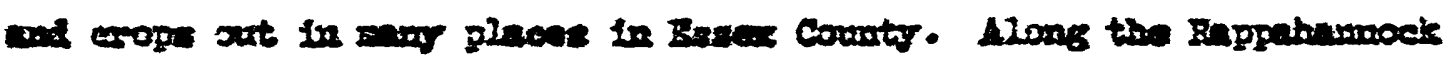

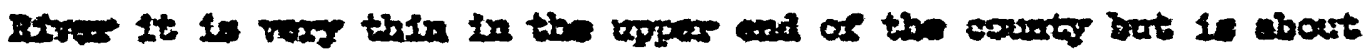

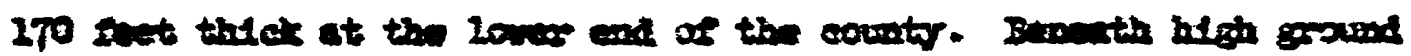

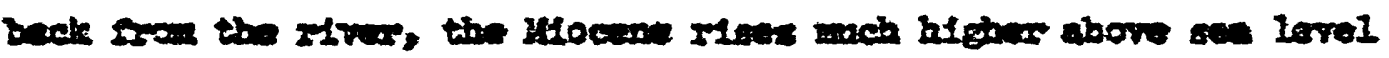

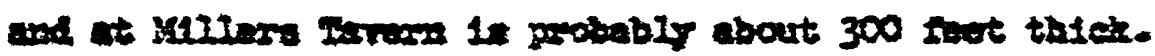

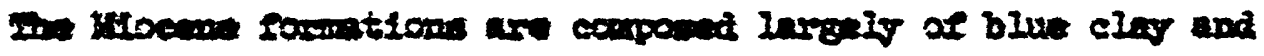
shell ans and subosilnate stos sumb.

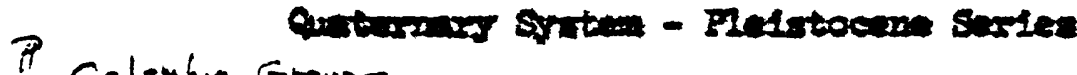
Colombia Group-

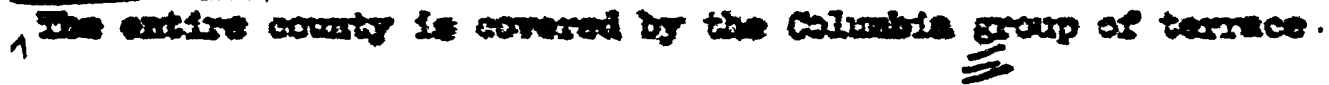

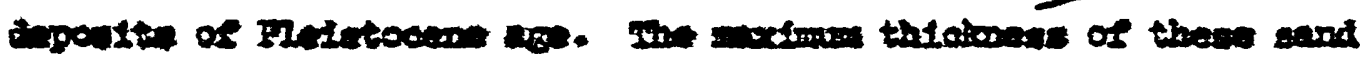

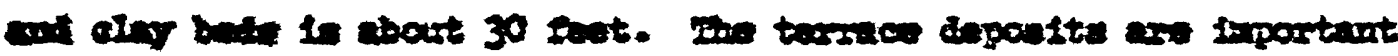

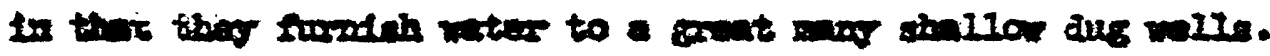

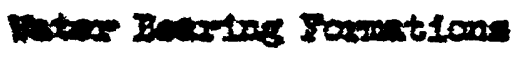

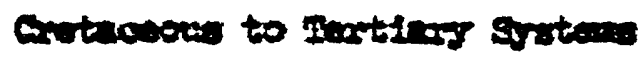

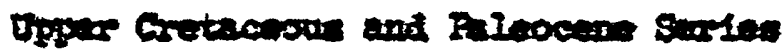

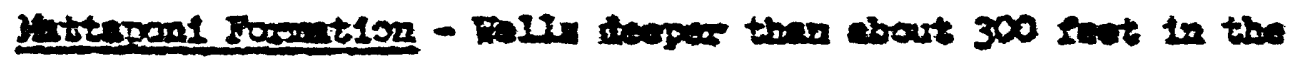

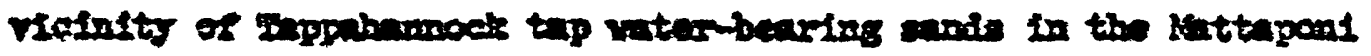
roxintion. Weils 14 to 17 and in a mandy seetion about 370 feet below sea level. A 21

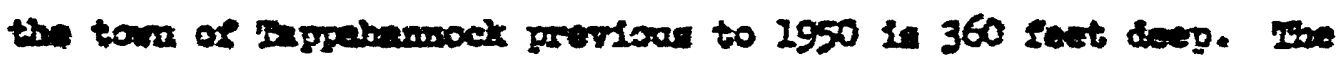

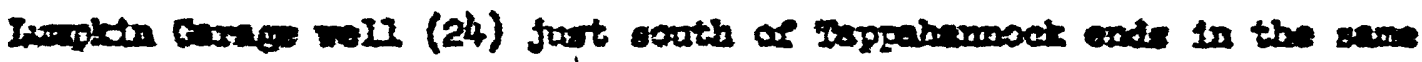




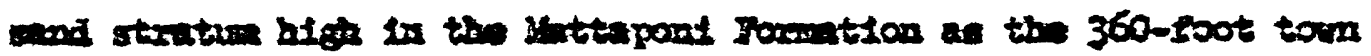

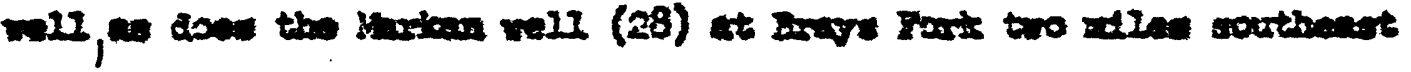
of mpposmonowis.

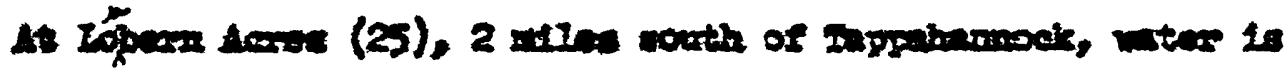

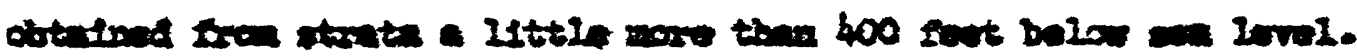

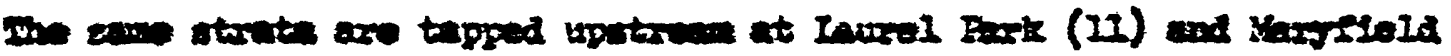
(23) houstong dovelogmatio.

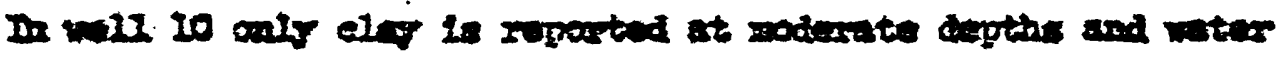

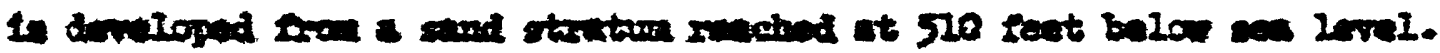

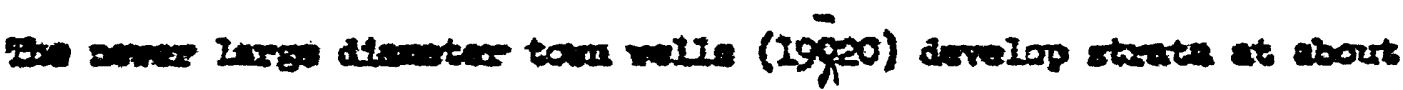

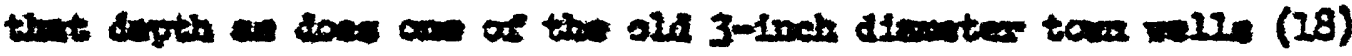

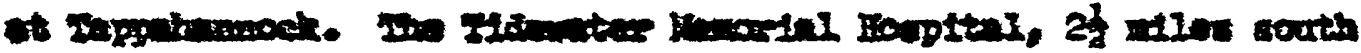

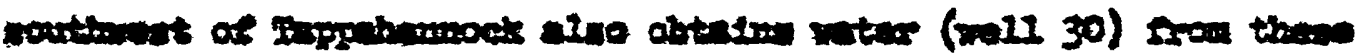
ders ande.

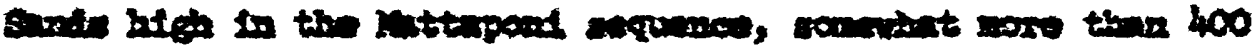

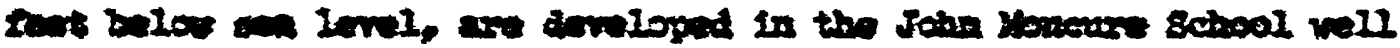

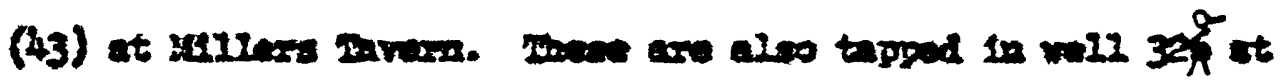
Domoritle.

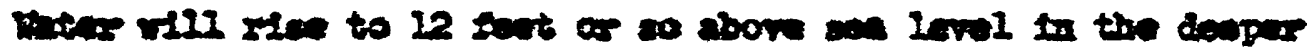

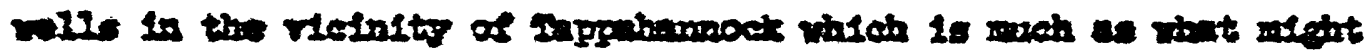

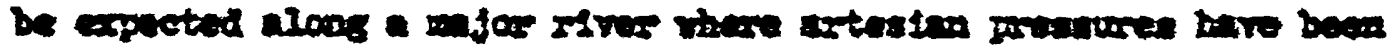

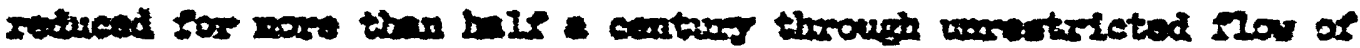
mols on 100 ground. However,

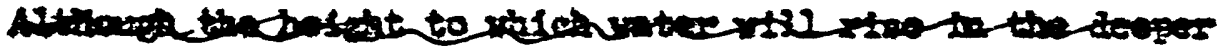

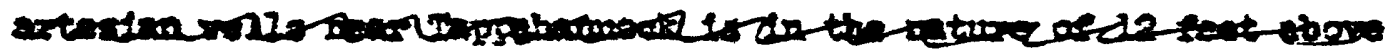




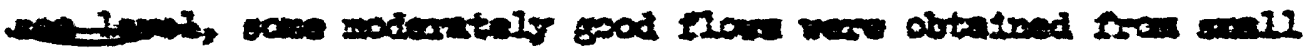

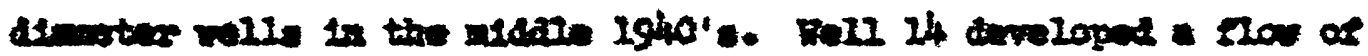

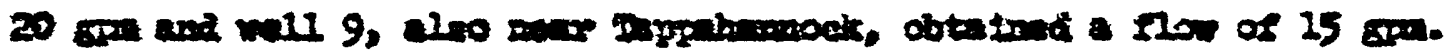

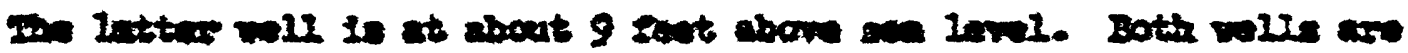

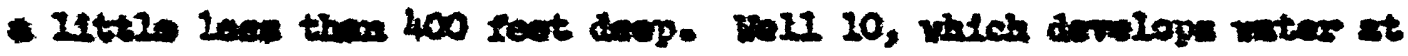

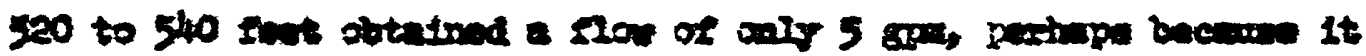

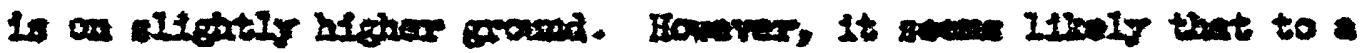

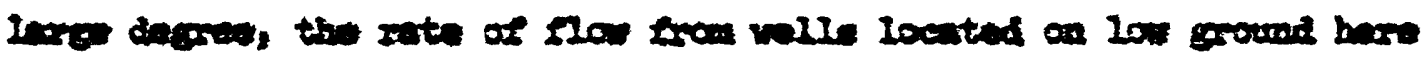

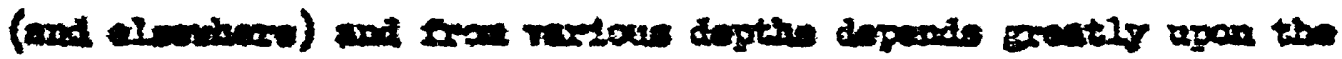

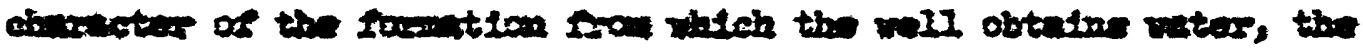

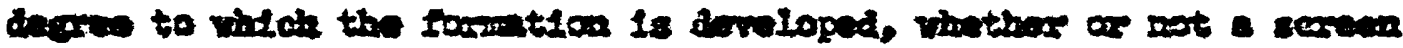

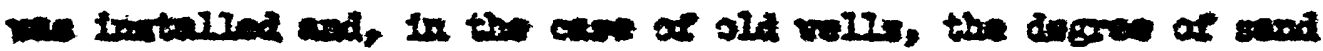

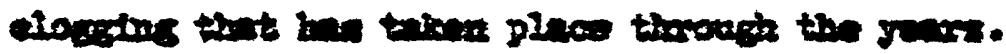

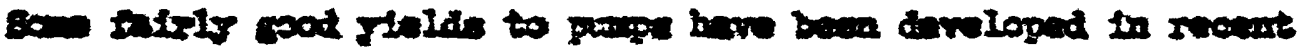

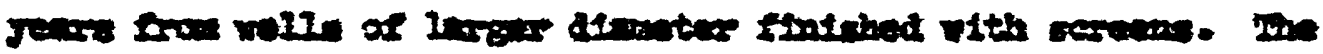

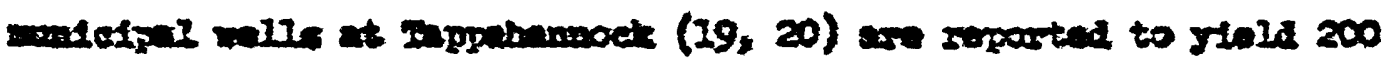

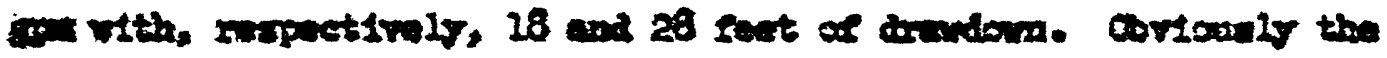

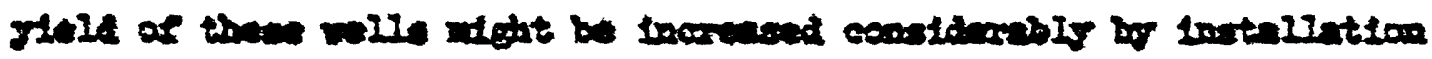

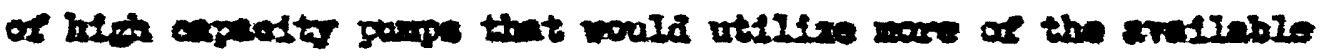

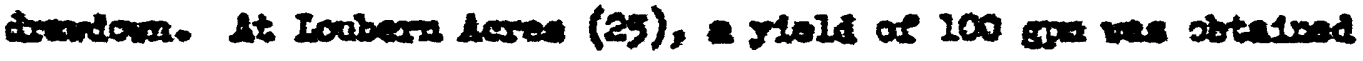

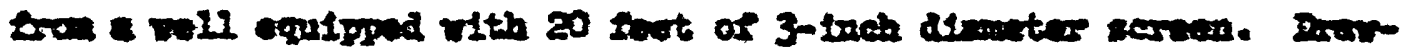

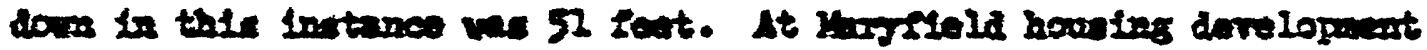

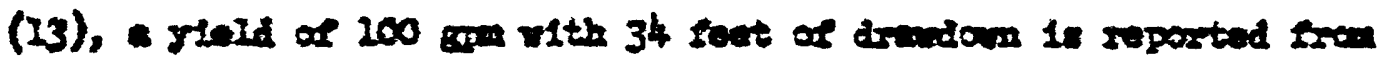

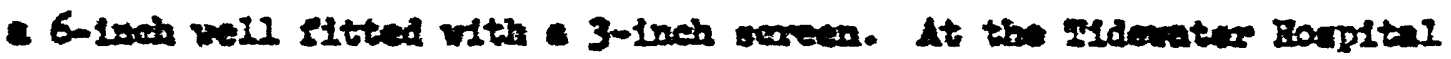

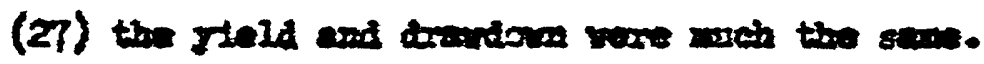




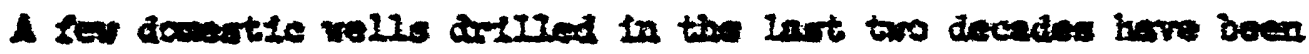

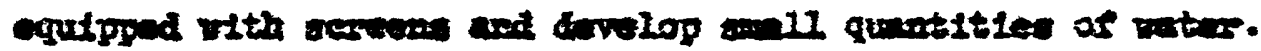

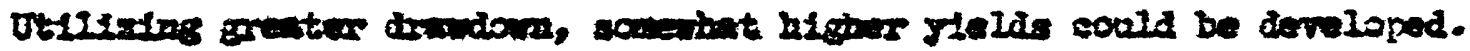

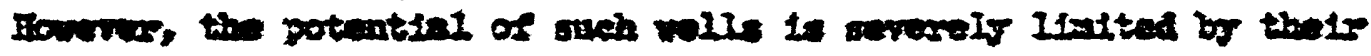

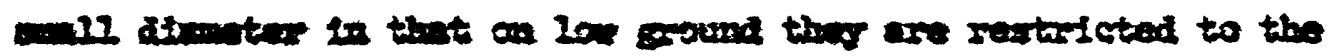

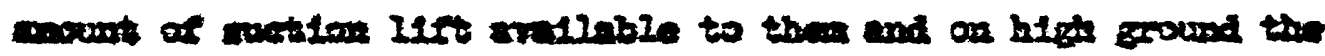

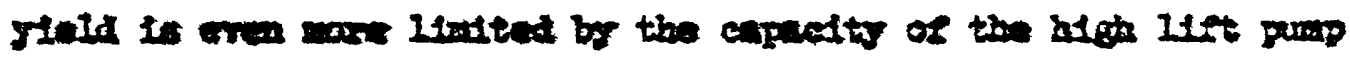
thet en be Intalind. 
Essex

The upper section of the Mattaponi Formation in the Tappahannock area does not contain as thick or as coarse water-bearing sands as at West Point which lies directly south of the lower end of Essex County. However, the most prolific sands at West Point are first penetrated about 350 feet below the top of the Mattaponi Formation. At Tappahannock it would appear that the deepest wells only begin. to reach the zone where thick gravelly beds might be expected. It is likely deeper drilling in the county would penetrate additional permeable sands from which yields up to a million gallons a day (700 gpm) of high quality water per well could be developed.

A number of wells in and near Tappahannock listed by Sanford $(p .304-7)$ at the time of his survey in 1906 are 270 to 280 feet deep. Apparently these end in glauconite sands that are present just below the red or brown clay stratum discussedowe that is thought to mark the top of the Mattaponi Formation here. None of these wells had large flows although many were located on very low ground. Sanford notes (p. 166) that in one such well the flow was $5 \frac{1}{2}$ gpm but it was said to have been $12 \mathrm{gpm}$ initially. Presumably, by 1906 t unrestricted flow of many wells up and down the river had already reduced the artesian head. In a 272-foot well (i)mile upstream from Tappahannock artesian head was said to be as much as 30 leet above high tide level in 1906. A great many of these wells have fallen into disuse and very few are listed in fable 4 . 


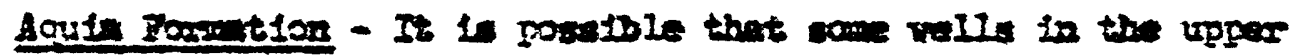

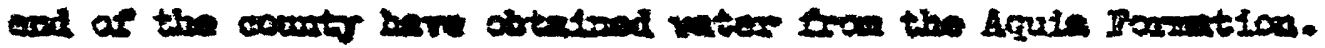

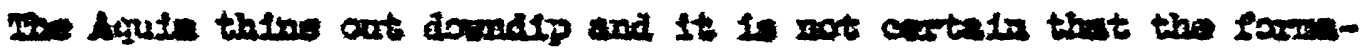

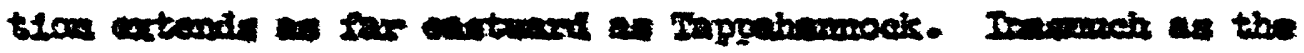

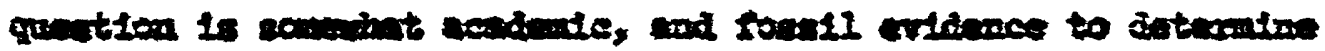

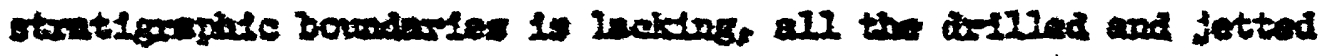

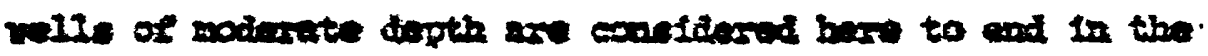
instinos posention.

$$
\text { Tertiary Syatem }
$$

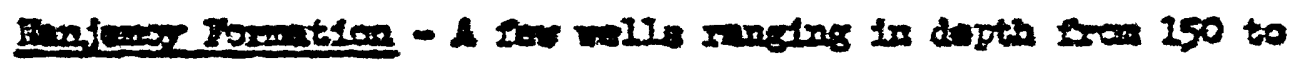

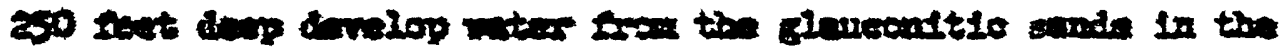

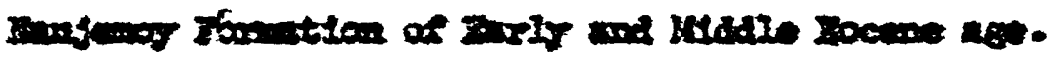

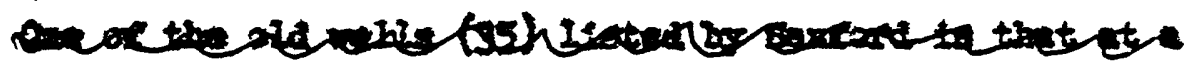

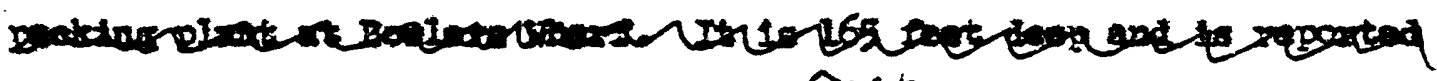

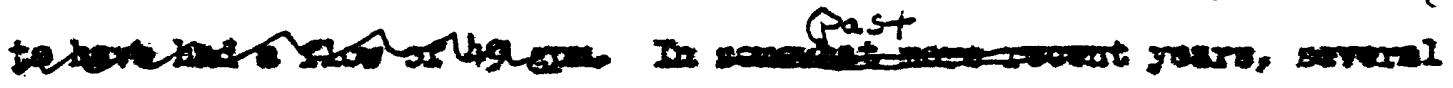

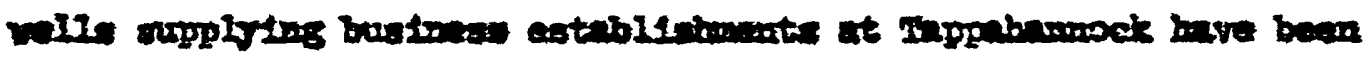

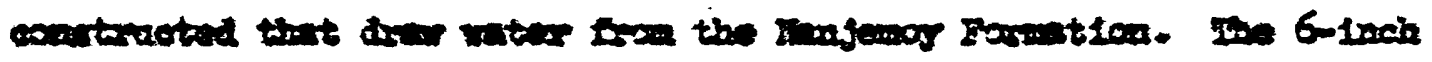

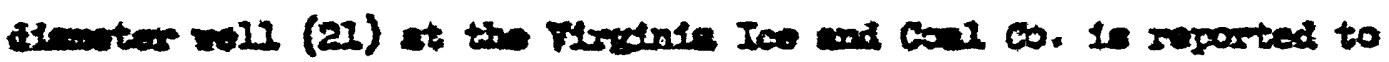

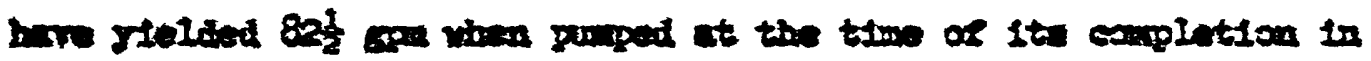

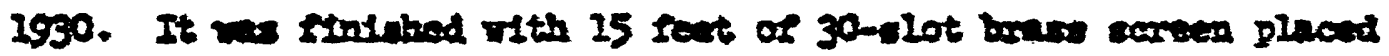

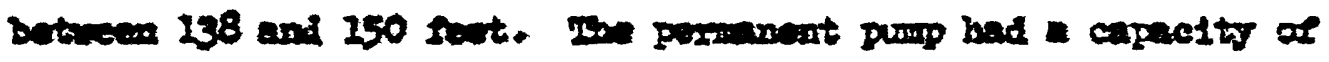

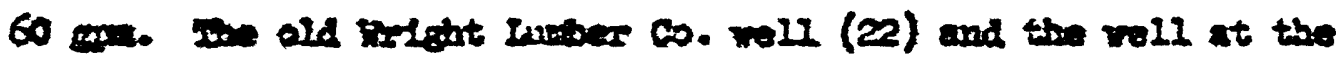

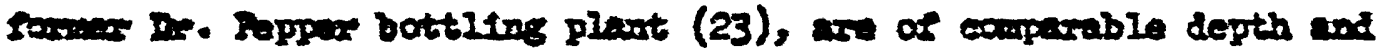
and in the singenos. 


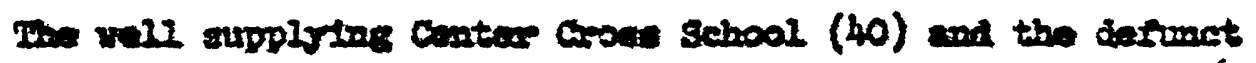

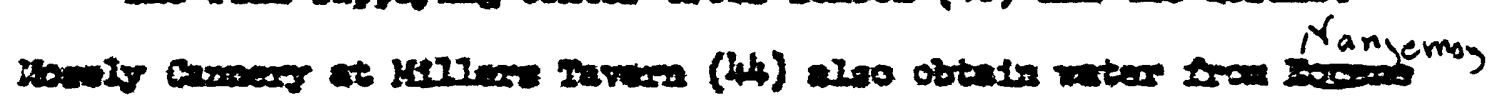

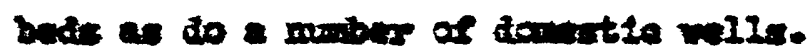

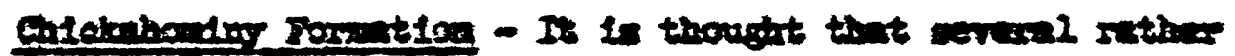

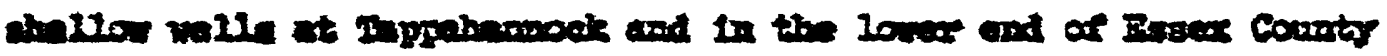

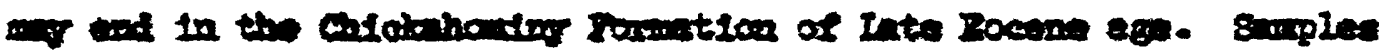

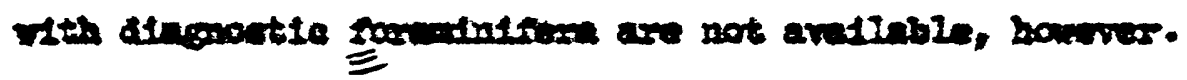

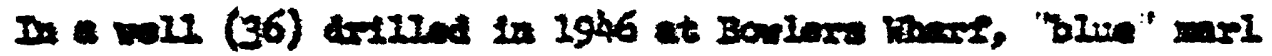

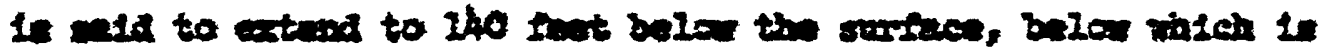

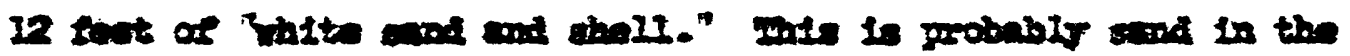

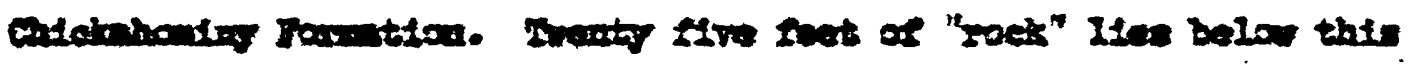

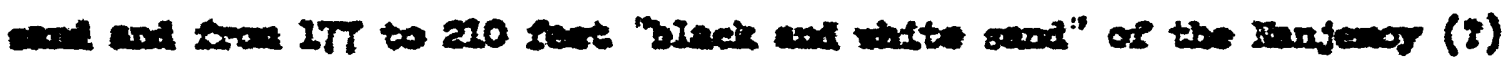

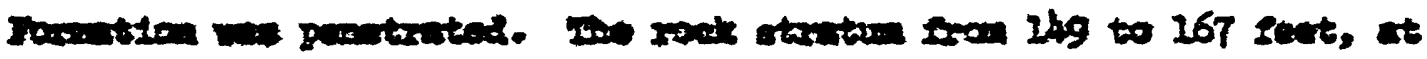

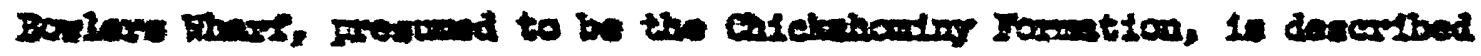

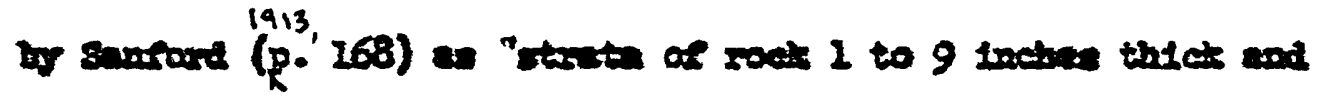

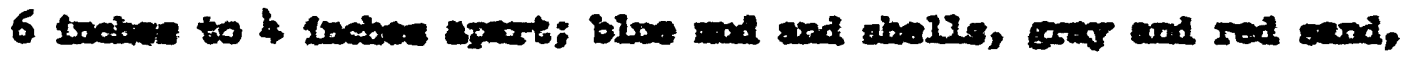

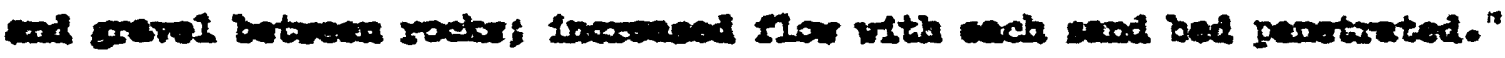

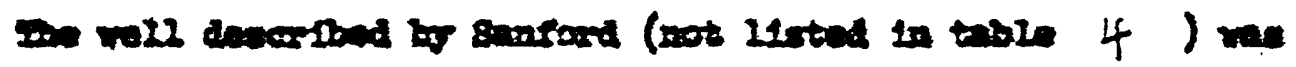

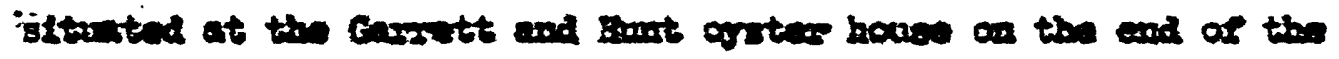
whes. It bad a $10 \mathrm{w}$ of $30 \mathrm{gpm}$

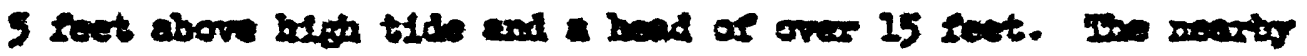

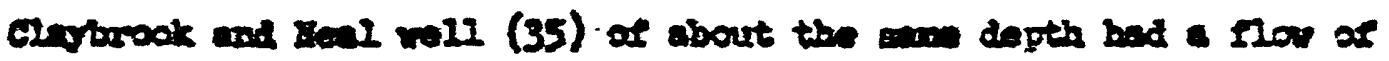
49 ara at 12 sect bow high tia lewl. 


\section{Mloem sorites}

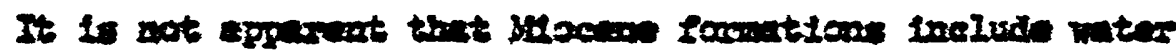

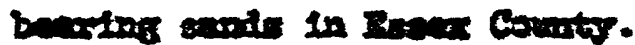

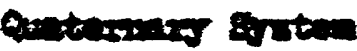

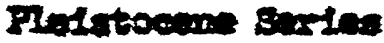

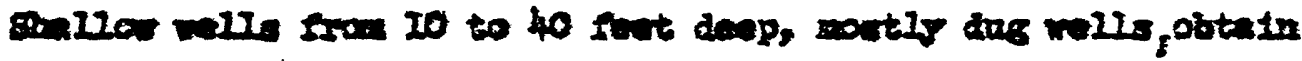

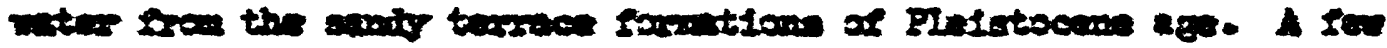

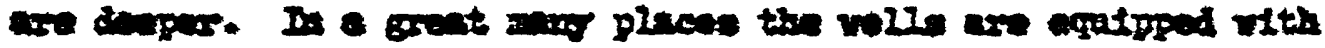

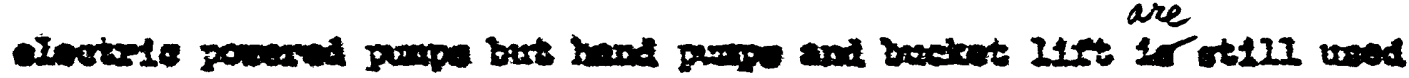

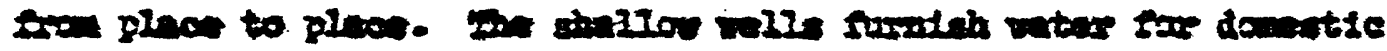

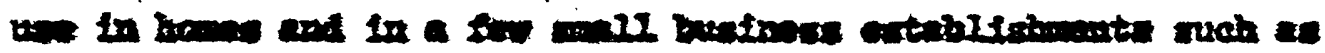
111ing station. 


\section{Onelity of Rater

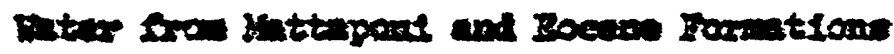

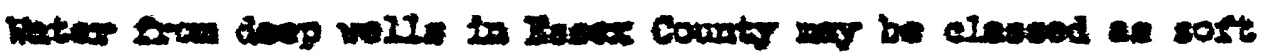

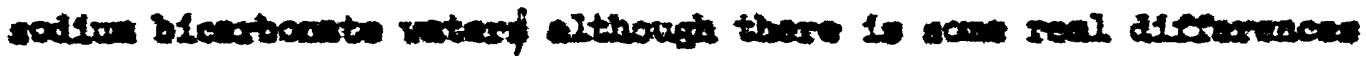

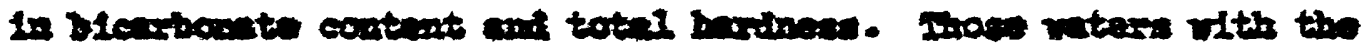

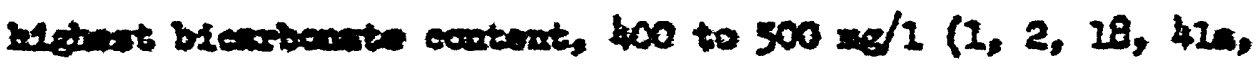

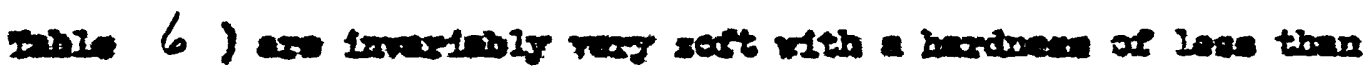

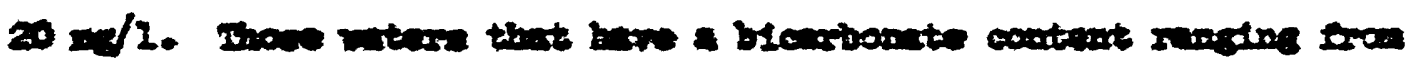

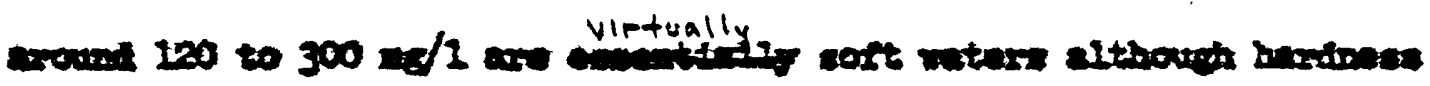

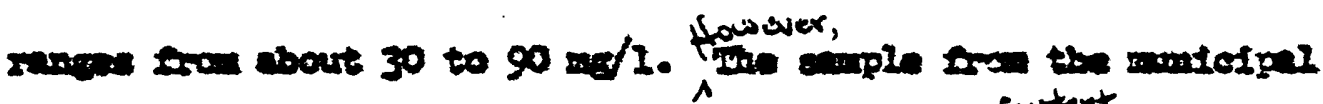

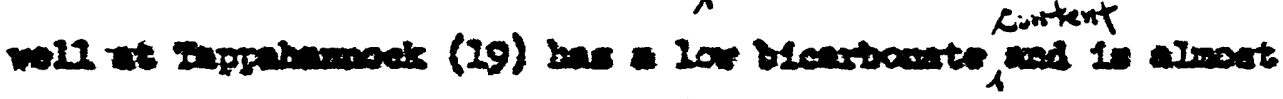

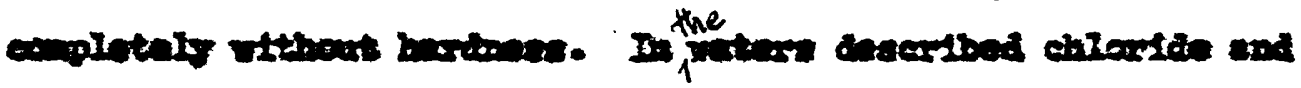
nento are 10 .

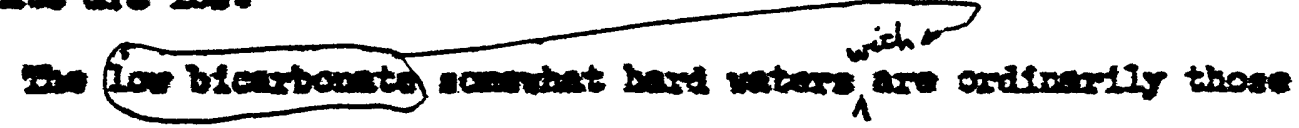

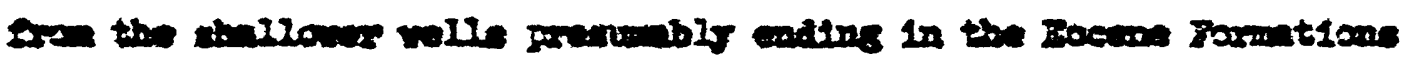

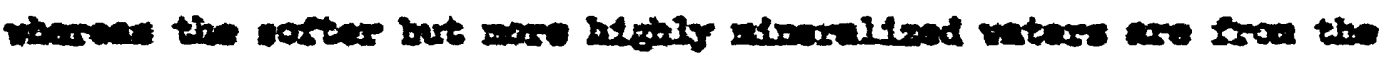

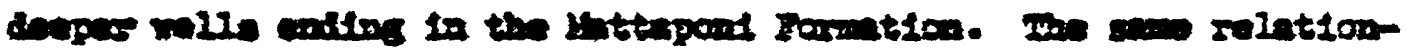

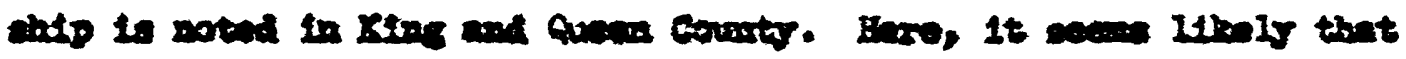

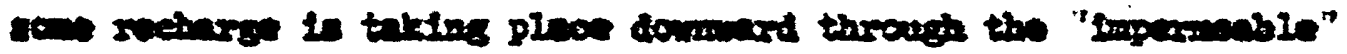

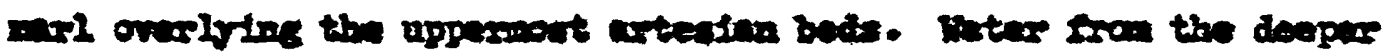

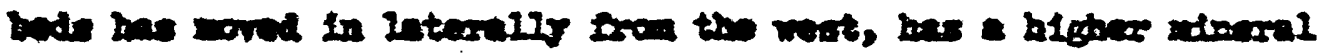

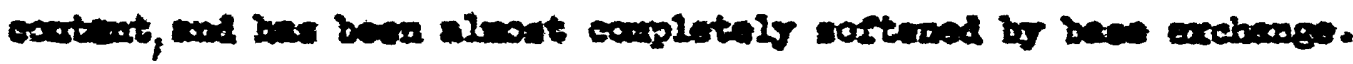

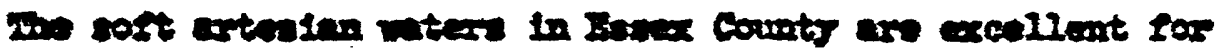

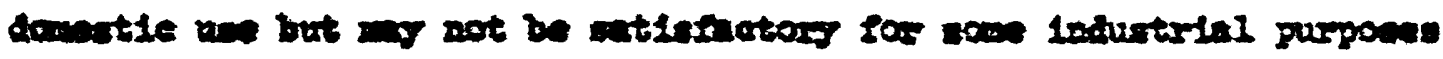




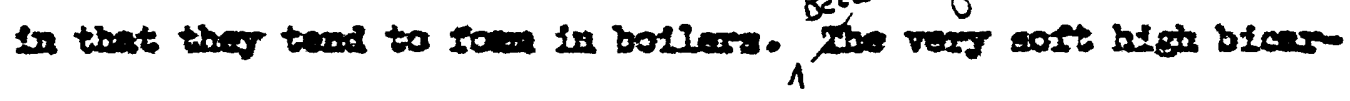

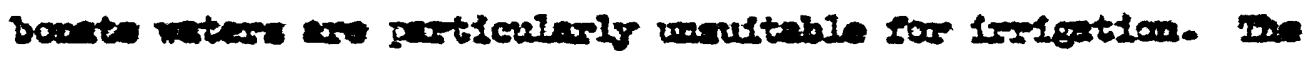

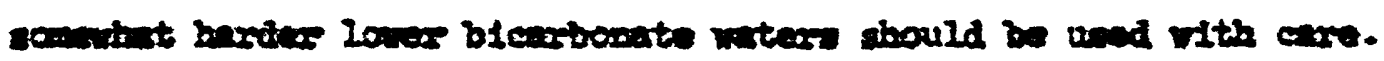

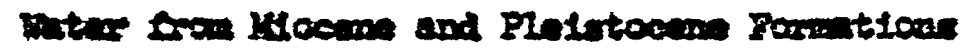

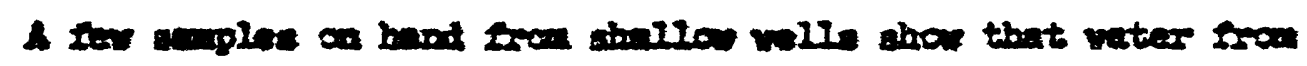

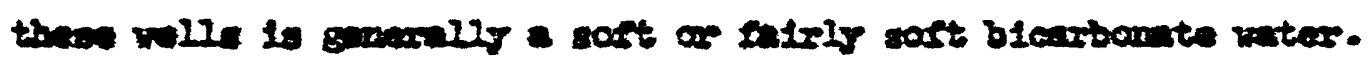

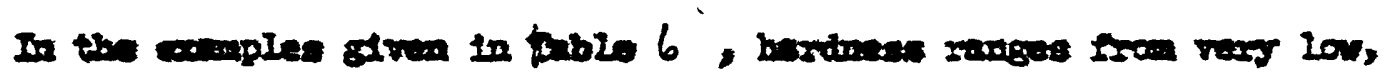

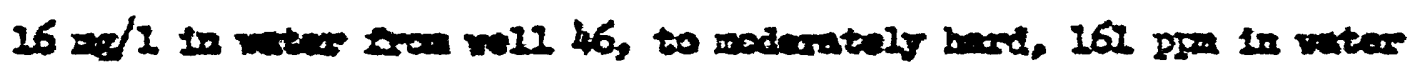

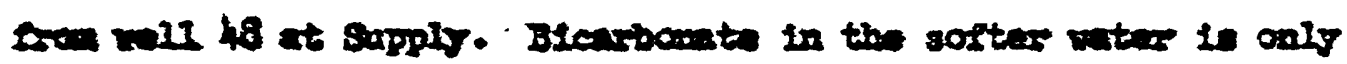

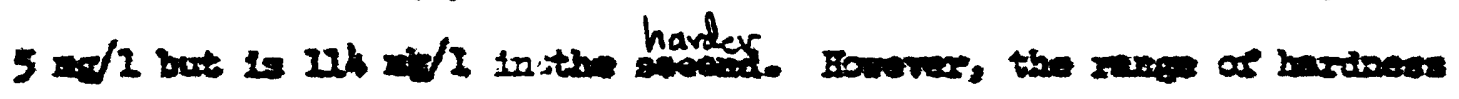

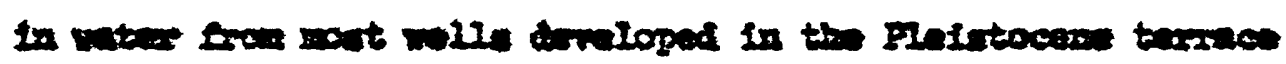

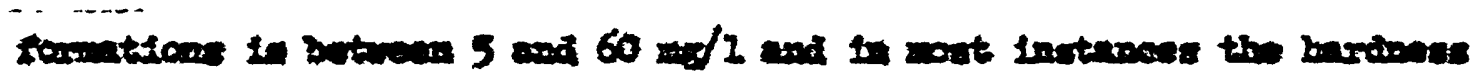

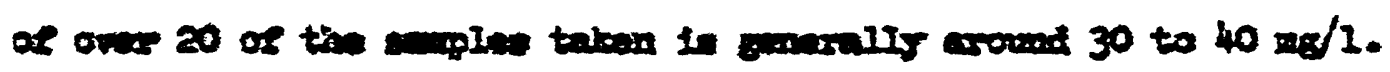

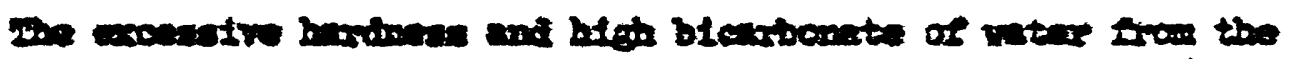

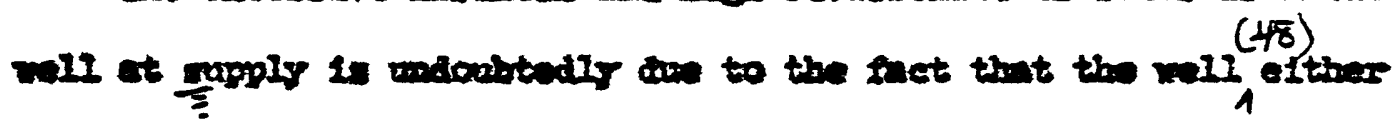

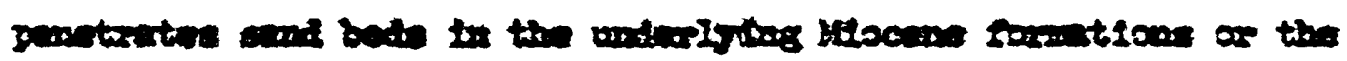

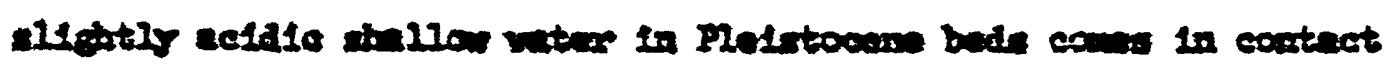

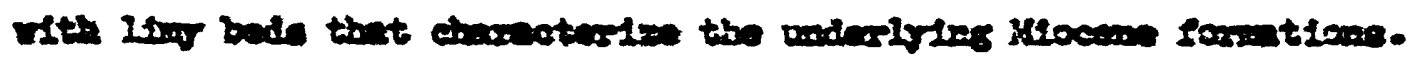

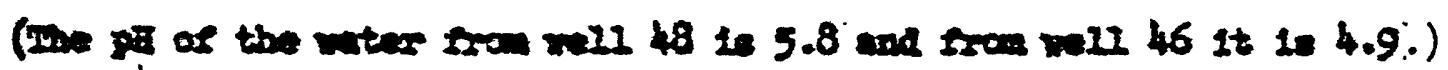
tom

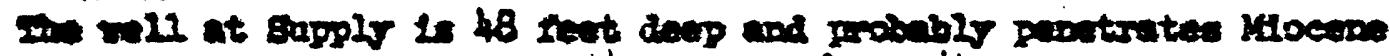
the water from it

wi in Ite low partion and is bard on thent neconont. 
Table 5 .--Iogs or wells in Essex County, Va.

Hell 10 , B. E. Bennett, $2-3 / 4$ miles south-southeast of Jenkins Iending

(Log by W. S. Reynolds)

Altitude $11 \frac{1}{2}$ feet

Columbia Group (Fleistocene)

sand, clayey

Chesapeake Group (Miocene)

Clas, blue

78

95

Nanjemoy Formation (Eocene)

I Marl, sandy, white; thin rock stratum at basto

28

123

Sand, black and white

2

125

Clay with rock streaks

25

150

Aquia (3) Formation (Paleocene)

Clay, hard

55

205 Sattapon1 Formation (Feleocene) Upper Cretaceous an

Clay, bard

45

250

Cley, red

22

272

sand, clayey, Eray

30

302

Rocks

$\frac{1}{2}$

$302 \frac{1}{2}$

clay, bard, blue

$50 \frac{1}{2}$

353

Clay, light to dark brown

62

415

Cley, white to yellow

65

480 
Trable 5 .-Iogs of velle in Basex County, Me. (cont.)

woll $10^{\circ}$, B. B. Bemett, 1-3/4 met3es Bouth-goutbonst of Jenken Ianding (cont.)

(Log v. 8. Respoldin)

\begin{tabular}{|c|c|c|}
\hline & $\begin{array}{c}\text { thotaleneas: } \\
\text { (10et) }\end{array}$ & $\begin{array}{l}\text { Depth } \\
\text { (feot) }\end{array}$ \\
\hline \multicolumn{3}{|c|}{ 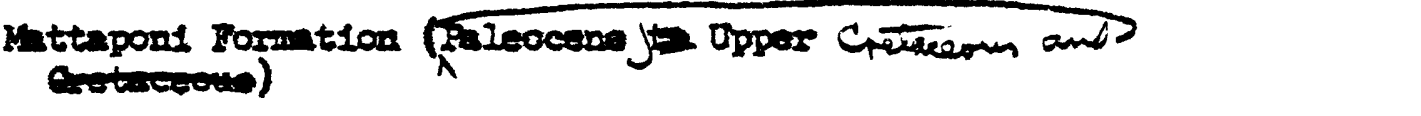 } \\
\hline Clay, bard & 25 & 505 \\
\hline Cles, red to brons & 15 & 520 \\
\hline suad, whites vater & 20 & 540 \\
\hline exp & 10 & 550 \\
\hline
\end{tabular}

IJ ona-bale soot of black sand il reported at 97 feet in well $q$.

b) sort brom eing is reported at 231 to 265 feet in well it and 1. underinen by $1 \frac{1}{2}$ feet of gleucontte sand. Fivolest of-

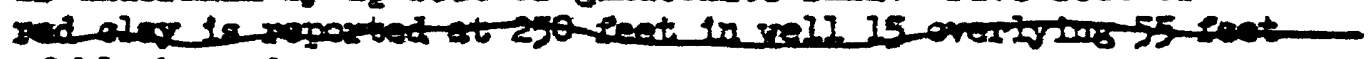
of sinekrand. 
Table 5 .--Iogs of wells in Essex County, Va. Weil 15 , Overton Brooks, Tappahannock (Iog by Leonard Reynolds)

Altitude 5 feet

$$
\begin{gathered}
\text { Thickness } \\
\text { (feet) }
\end{gathered}
$$

Depth

(feet)

Columbia Group (Pleistocene)

Clay, sandy

Chesapeake Group (Miocene)

Clay, blue

67

85

Chickahominy (?) Formation (Eocene)

Shells and gray sand

Clay, blue

$11 \frac{1}{2}$

99

Shells and sand

$1 \frac{1}{2}$

$100 \frac{1}{2}$

Nanjemoy Formation (Escene)

Clay and rock

$19 \frac{1}{2}$

120

Sand, black and gray

$1 \frac{1}{2}$

$121 \frac{1}{2}$

Sand, white, and limestone

4

$125 \frac{1}{2}$

clay, compact

$18 \frac{1}{2}$

144

Limestone

$\frac{1}{2}$

$144 \frac{1}{2}$

Clay, hard

$18 \frac{1}{2}$

163

Limestone

$\frac{1}{2}$

$163 \frac{1}{2}$

Aquia (?) Formation (Paíacene)

Clay, compact

$26 \frac{1}{2}$

190

Sand, black

2

192 
Table 5 .--Iogs of wells in Essex County, Va. (cont.) Well is, Overton Brooks, Tappahannock (cont.)

(Log by Leonard Reynolds)

Altitude 5 feet

\begin{tabular}{lcc} 
Mattaponi Formation((Fleocene) & $\begin{array}{c}\text { Thickness } \\
\text { (feet) }\end{array}$ & $\begin{array}{c}\text { Depth } \\
\text { (feet) }\end{array}$ \\
\hline Claper Cretaceous & & \\
Clay, compact & 58 & 250 \\
Clay, red & 5 & 255 \\
Sand, black & 55 & 310 \\
Clay, hard & 5 & 315 \\
Limestone, very hard & 1 & 316 \\
Alternating clay and white sand & 81 & 397
\end{tabular}




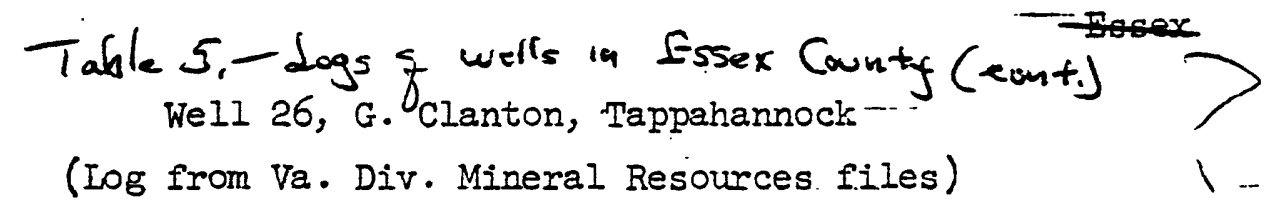

Altitude 20 feet

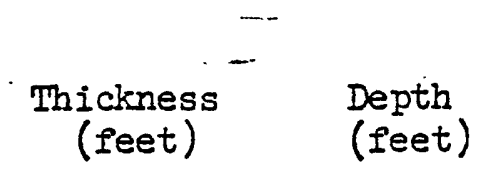

Columbia Group (Pleistocene)

Sand, fine

Chesapeake Group (Miocene)

Marl, blue

Chickahominy Formation (Eocene)

Rock, hard

Marl, blue

Rock, soft

Nanjemoy Formation (Eocene)

sand, black, fine

Undifferentiated (Eocene to Upper Cretaceous)

Mud, blue, gumny

Sand, black

Sand, white
27

27

99

126

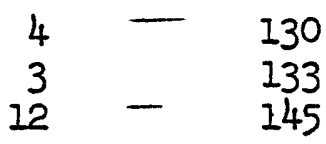

10

155

130
101
17 $\quad \begin{aligned} & 285 \\ & 386 \\ & 403\end{aligned}$

DOES ROT AGREE WITA

$W E L L 26$ /R TABLE \& 
Table 5 .--Iogs of wells in Essex County, Va.

Well 28, Brays Fork, R. A. Markan, (Triangle Inn)

(Log by Ieonara Reynolds)

Altitude 40 feet

Thickness

(feet)

Depth

(feet)

Columbia Group (Pleistocene)

Sand and clay

32

32

Chesapeake Group (Miocene)

Clay, blue

82

114

Sand, white, fine

$\frac{1}{2}$

$114 \frac{1}{2}$

clay, blue

$23 \frac{1}{2}$

138

Chickahominy Formation (Eocene)

Irimestone

Clay, blue

Nanjemoy Formation (Eocene)

Sand, black and white

Clay

. Limestone

Clay

Clay, very hard

$\Rightarrow$ Iimestone

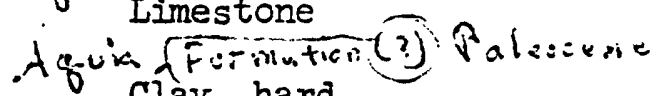

clay, hara

Sand, black $\frac{1}{2}$

$14 \frac{1}{2}$

$138 \frac{1}{2}$

153

$\frac{1}{2}$

$153 \frac{1}{2}$

$1 \frac{1}{2}$

155

1

156

10

166

8

174

1

175

32

207

2

209 
Table 5 .--Iogs of wells in Essex County, Va. (cont.) Well ac, Brays Fork,. R. A. Markan, (Triangle Inn) (cont.)

(Iog by Leonard Reynolds)

Altitude 40 feet

Thickness

(feet)

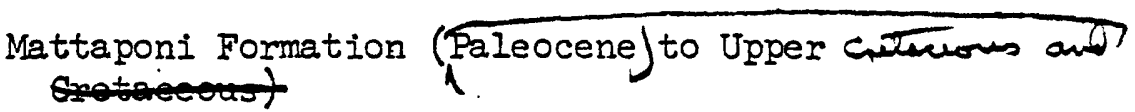

Clay, blue

Clay, red brown

Iimestone

Sand, black

Iimestone

Clay, hard

Sand, white

Clay, hard

Sand, greenish, muddy
63

270

7

I

$-54-$

332

4

336

41

377

$I$

378

10

388

24

412 


$$
\begin{aligned}
& \text { Table 5. Logs } f \text { wells in Essex County (cont.) }
\end{aligned}
$$

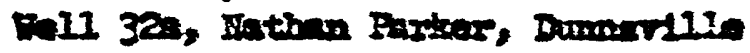

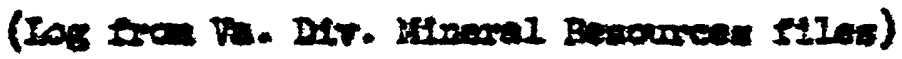

$$
\begin{aligned}
& \text { Alstawio } 65 \text { sout }
\end{aligned}
$$$$
\begin{aligned}
& \text { 2uleianges } \\
& \text { (20at) }
\end{aligned}
$$

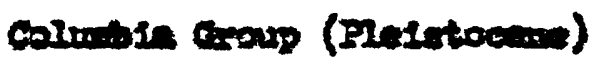

sond

30

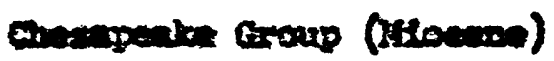

Ans, blus, and brow

1 10

270

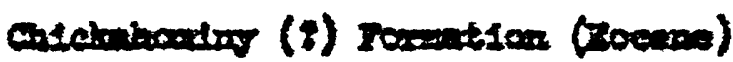

socise and wite and

6

276

GIv. DI0:

20

186

stanciside

2

188

cory, Din.

6

296

Eteon, hand

16

220

2nt. BIneis

23

230

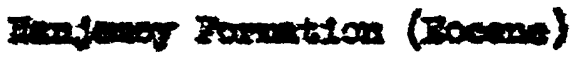

ant, bist

70

300

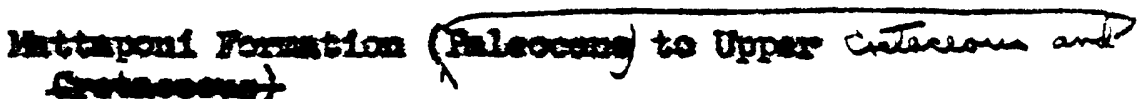

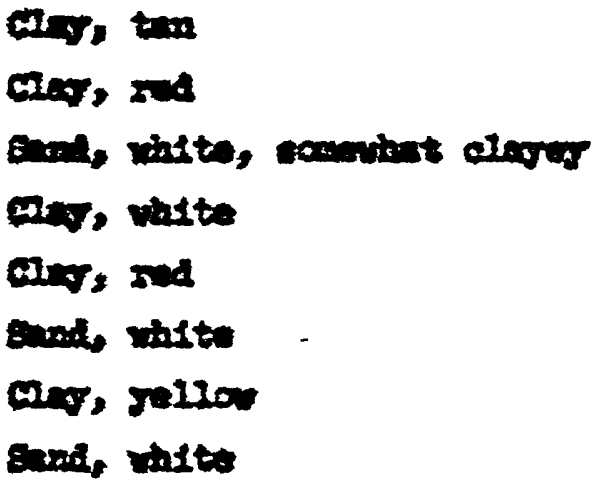


Table 5 .--Iogs of wells in Essex County, Va.

Well 36, Bowlers Wharf; R. A. Pitts

Clog by heonarl Reyniliss)

Aititude, 7 feet

Thickness Depth

(feet)

(feet)

Columbia Group (Pleistocene)

sand, yellow

20

20

Chesapeake Group (Miocene)

Marl, blue

120

140

Chickahominy Formation (Eocene)

Sand, white, and shell

12

152

Rock

25

177

Nanjemoy (?) Formation (Eocene)

Sand, black and white; water

33

210 


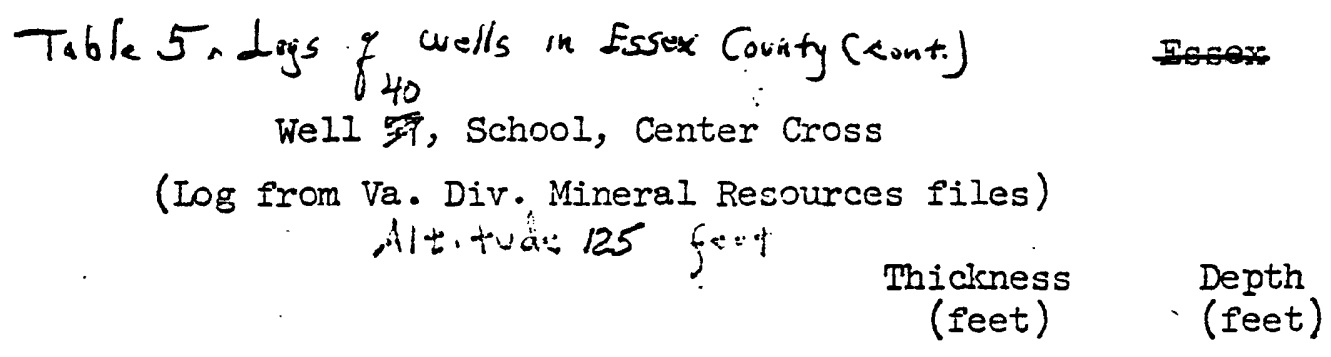

Undescribed

Chesapeake Group (Miocene)

Clay, blue

Chickahominy Formation (Eocene)

Stone, soft

Shell and white sand

Stone, hard

Sand, gray

Clay, brown

Shells and white sand

Stone, soft

Nanjemoy Formation (Eocene)

Sand, black

Stone and sand layers
$1 \quad 248$

$2 \quad 250$

1251

4255

5260

$5 \quad 265$

$10 \quad 275$

$5 \quad 280$

$60 \quad 340$ 


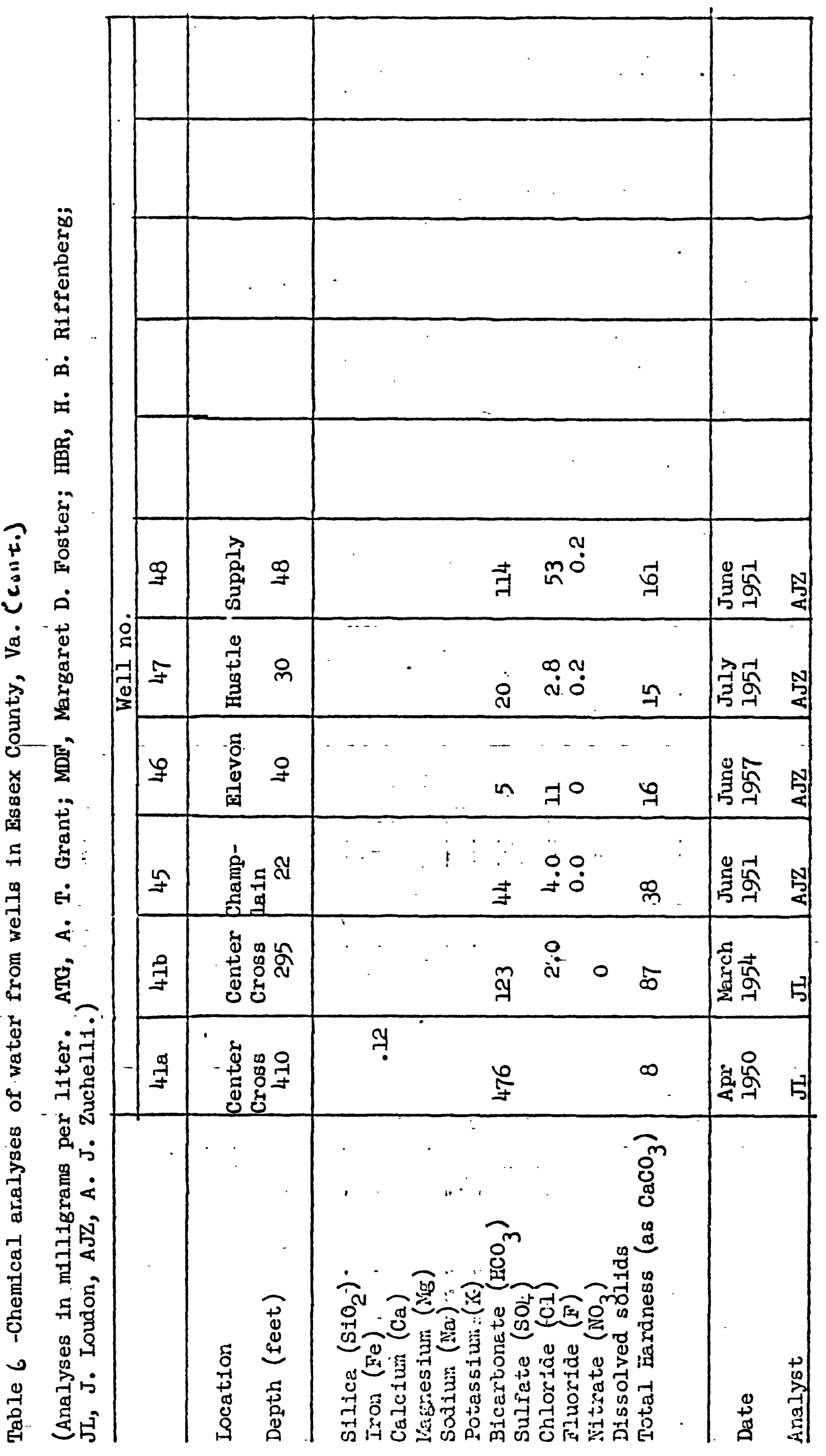




\section{Madlenex County}

Midaledes County Iles along the south bank of Bappahnnnock

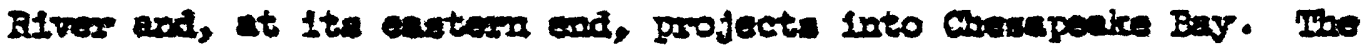
Inod are to 132 square adlea. The popalation in 1960 wes 6,319 of Which 512 Ifved in Urbann.

Although edsentially a raral county only about 15 percent of $\wedge$ iN? the vorkting force vas emploged in agricultarre. Whe nuber of papple employad if unnusacturing is not large. However, proceseing as sroah and frowen sonfood is an important industry in and around Urban, bontbutlaing mplogs a mber of individuals in the eartasy end of the county, and lumber in cut in several locallties.

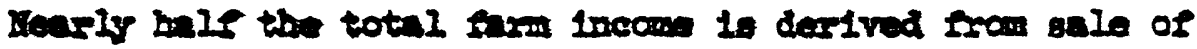

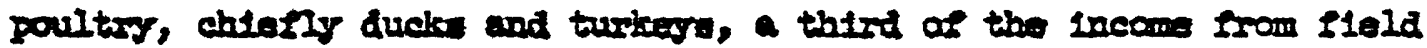
-and

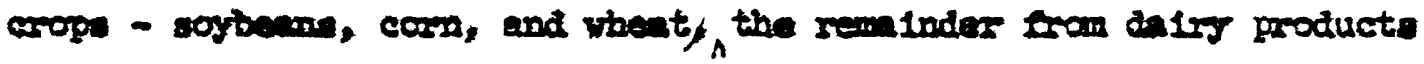
and Irveratods.

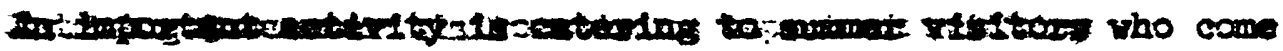
to enjog bathing, bonting, and flining, particulerly in the more enoterist purt of the county.

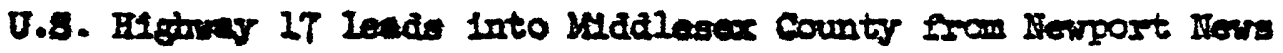
and passes through Ealudi and Urbenn and compets this section vith Fredulckoburg and other arterial highrays. There are no rallroadi in the coumty but bue aervice is avallabie. Bulk frelght can be shlpped in shallow andugt ressels on/Bappabannock Rtver. A mil alrport is located at Grey's Polnt, sonfe mllos northeast of salude. 


\section{Geologe}

The cowaty is undersines bo unconsollanted sediments of

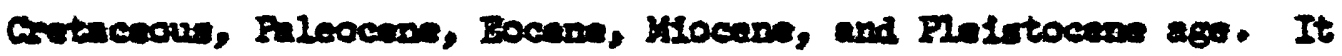

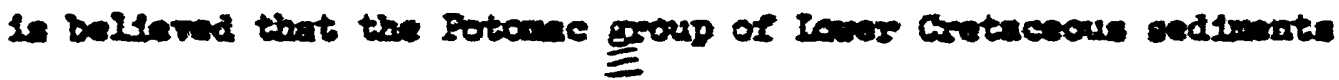

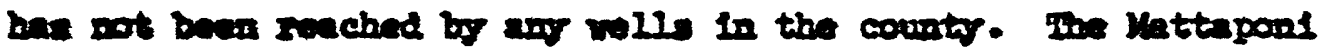
and

rosmation of Inte Cretaceoon to faleocon age in well developed.

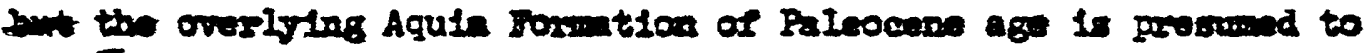
$=$

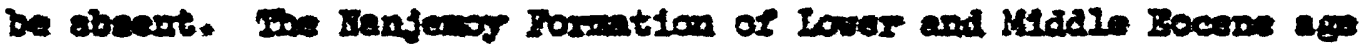

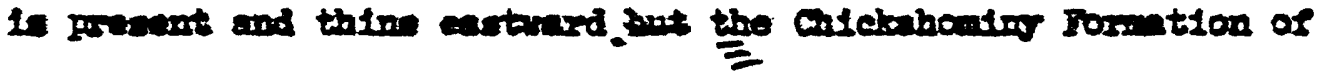

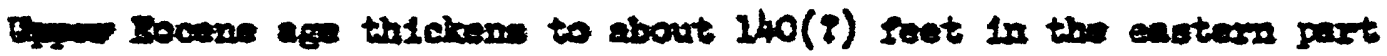
of the covata (pl. 1, wetton A-A').

$$
\text { Pre-Crataceovs Basiument Rouk }
$$
Badoel

Dopth to bedrock in Madiesex county is not known but reneos-

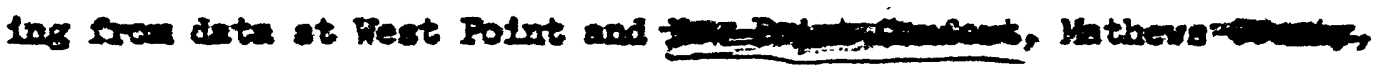
1t in be about 1,400 feot in the uppensuont end of the county and 2,300 feet in the lowerwort part of the county. 


\section{Grotacooun to Tertiary arstems}

Mttapon1 Format10n - Who Mattapont Forration of Oppers

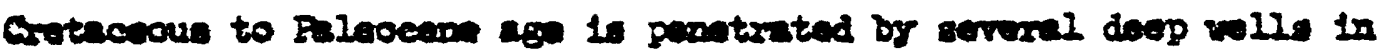

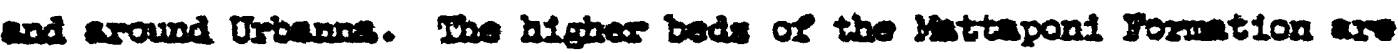
charncterintienly glaucoultio and bance disfleult to diotingalsh

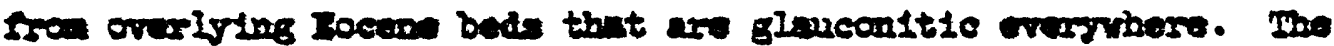

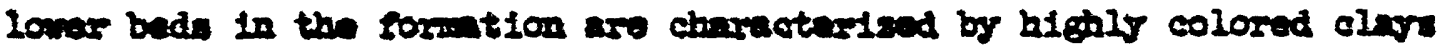
and elaveoudta woy or may not be present.

In a wall (19) drilled in 1906 for the town of urbann (Bnford, 1913,

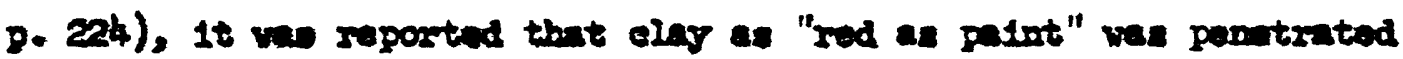

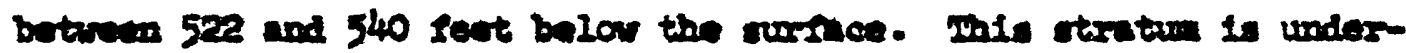

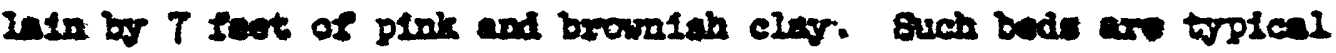
of the lower part of the kettupont Forwation. The 108 of the more

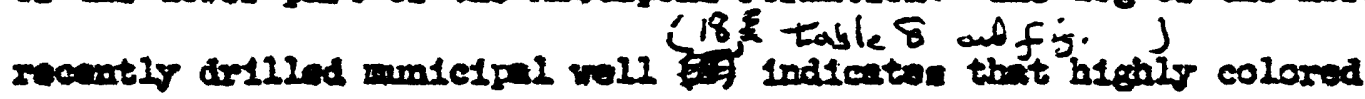
cilos extend to at leat 662 fent below the aursace.

Accossting to the 208 of well 9, the bleter boda in the

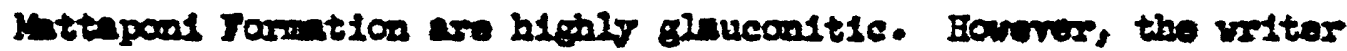

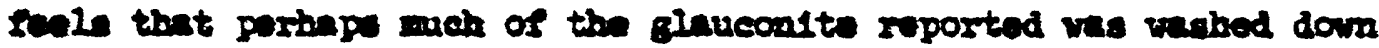

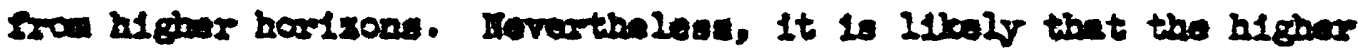

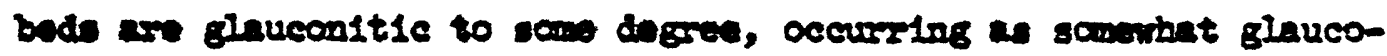
nftie blus clors and subordinate glauconftie quarts sands. In the shamon vell (20) the deopers strets are reported to be rather sondescript. 


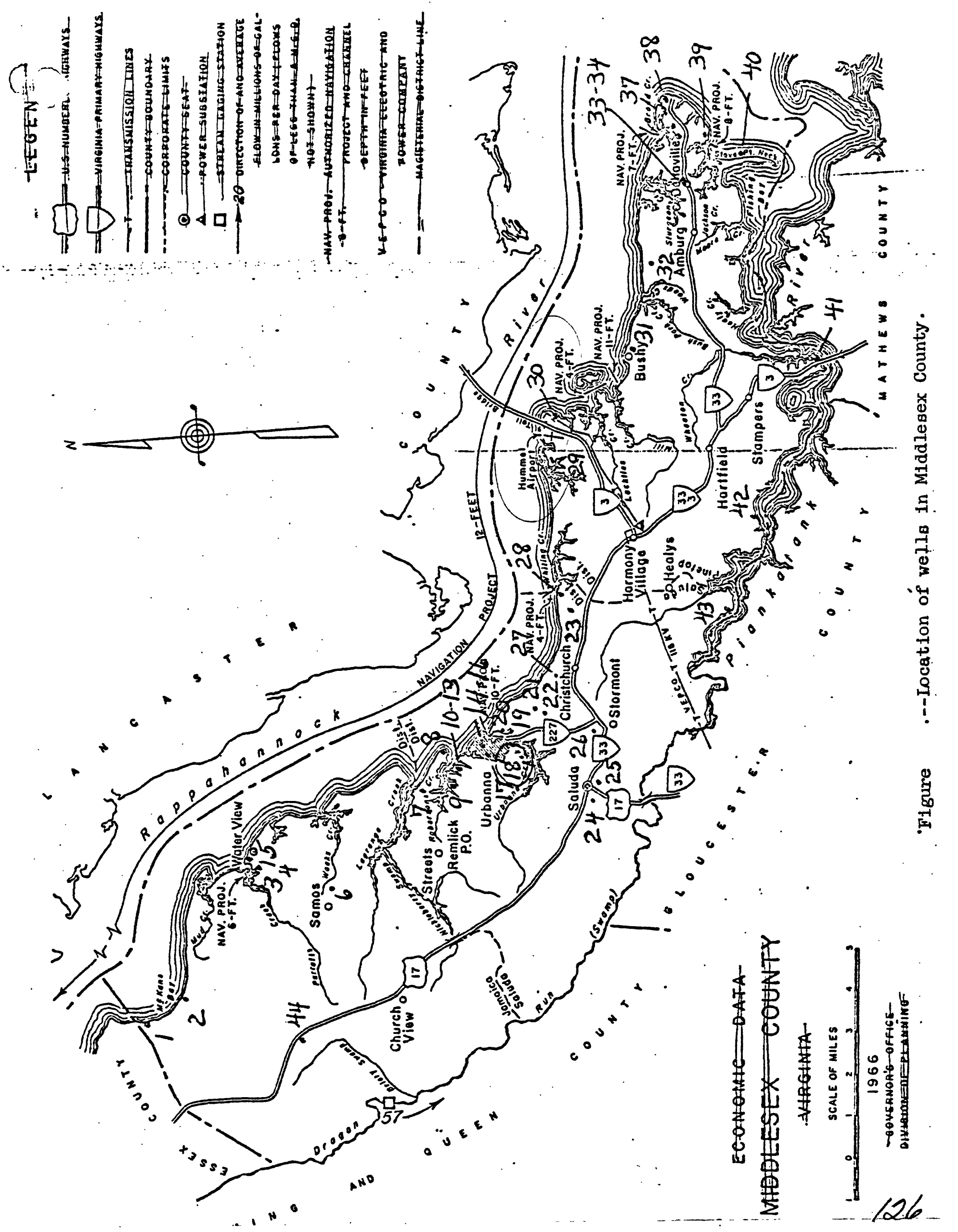




\section{Dustion Sratem}

\section{Iocane Sented}

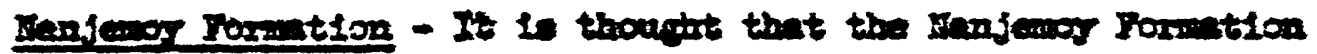

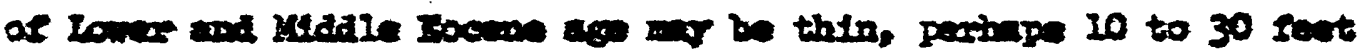

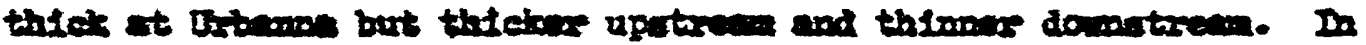

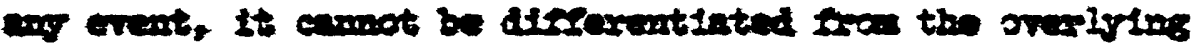

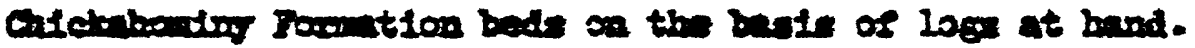

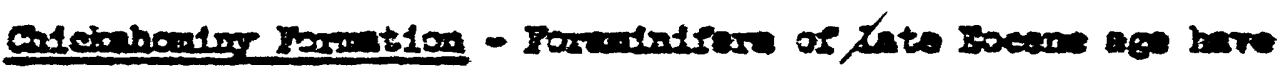

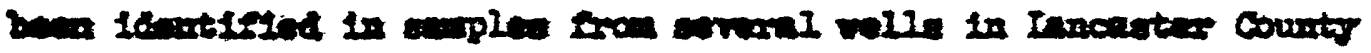

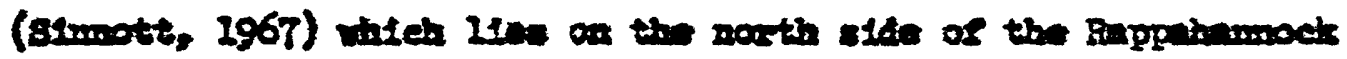

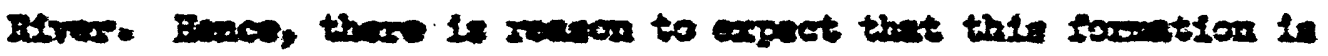

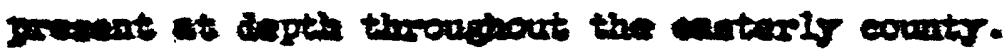

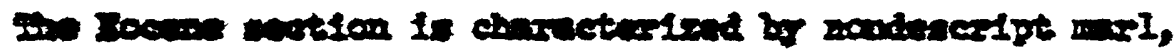

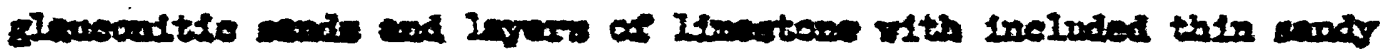

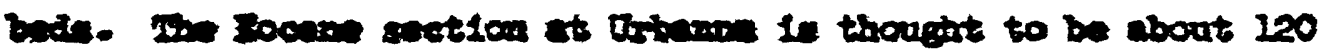

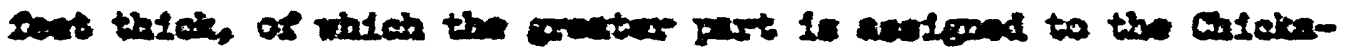

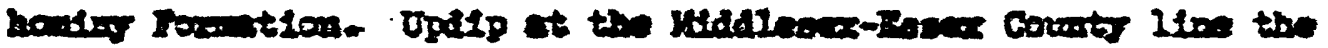

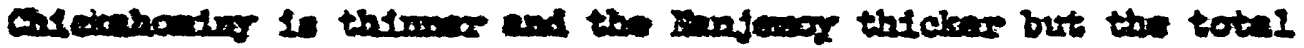

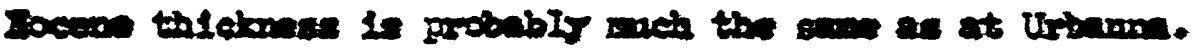

200 Ittholow of the cectione at M1Itan Folnt (4I) and 8tow

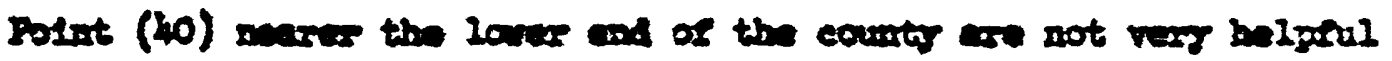

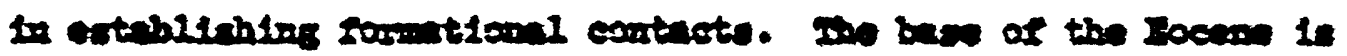

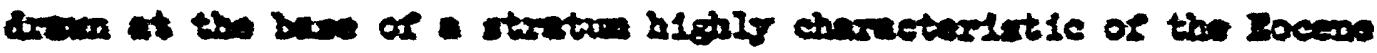

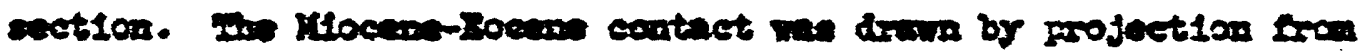
the are to the rest. 


\section{Dutex Bearing Parutions \\ Grotacesos to Pertingy sroten

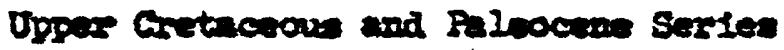

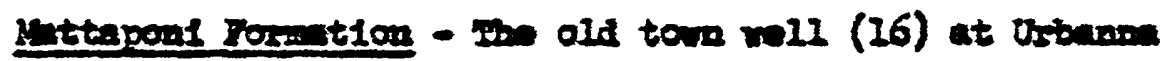

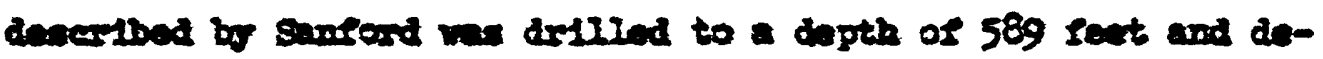

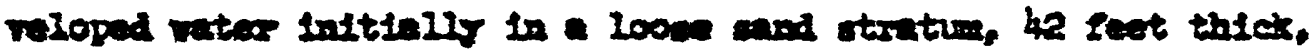

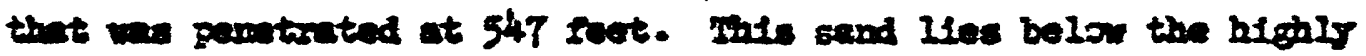

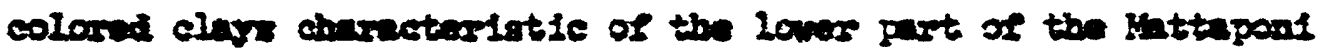

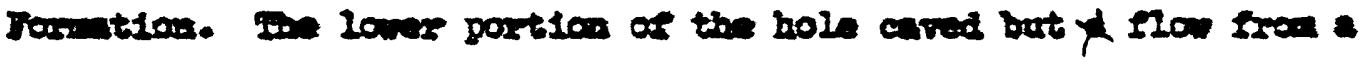

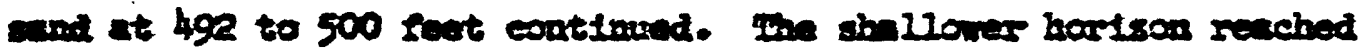

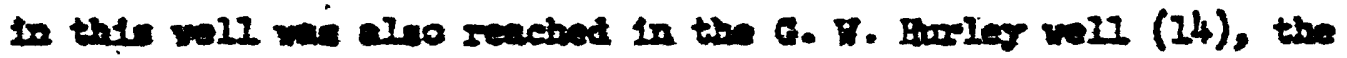

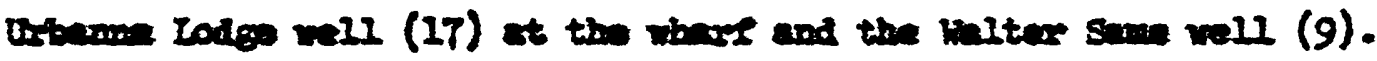

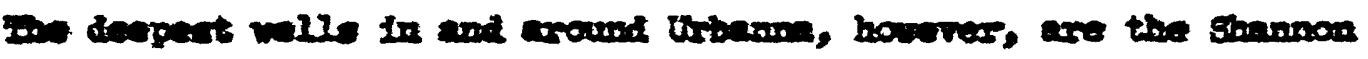

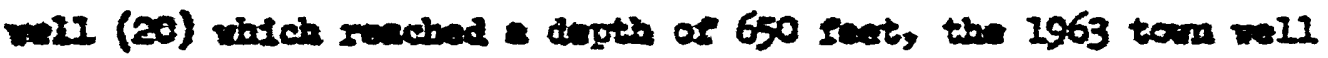
(18) 600 fret and and the BriII Drek Fwow welle (21, 22) which are about 650 sect deap.

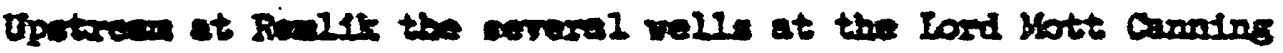
Co. $(12-13)$ exd in the knttrpous Foxintion.

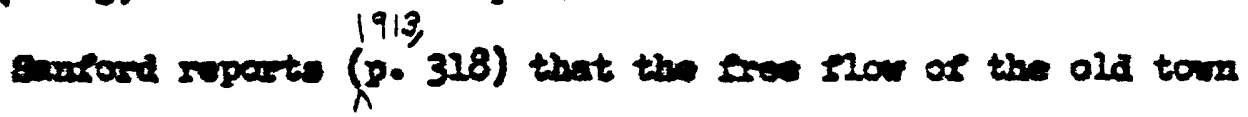

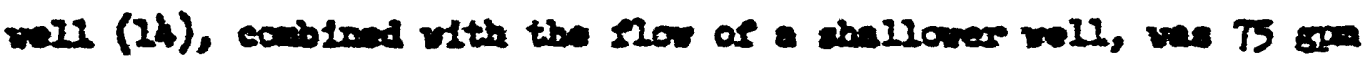

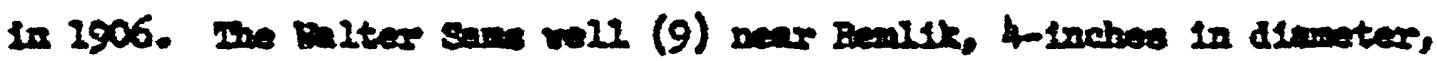
If easd to bur bad a Mor of $T 2$ ste in 1940.

The 1963 town wall (28) in roported to have been prupped at a

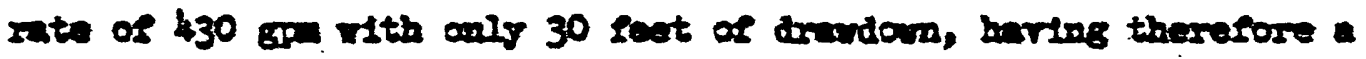

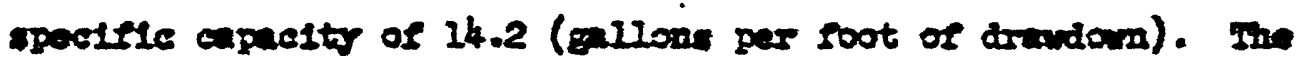
Shanow wil (20) vas pumped at a rate of 205 gran vith 39 sect of drwidoin and has apeclete enpects of 5.2 . 


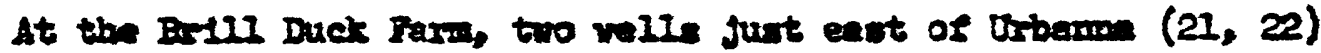

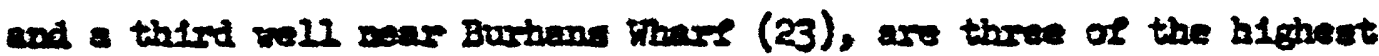
Feld welle in the county. Fielde are given as 752, 857, and 1100

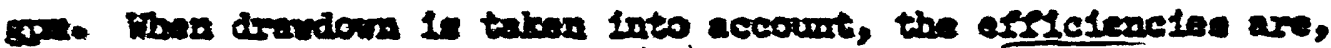
gpm.

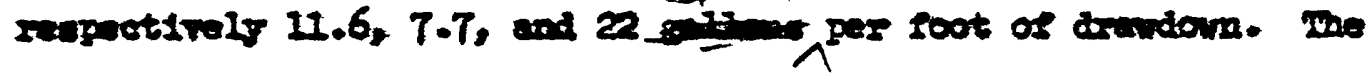

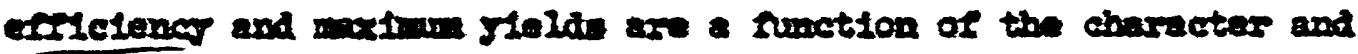
thleimest of sande penctanted and the amount of scroens used. The

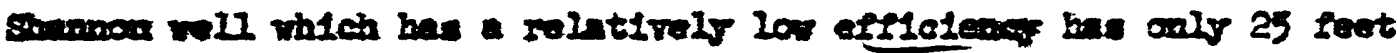

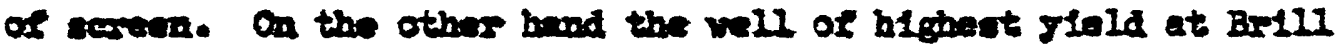

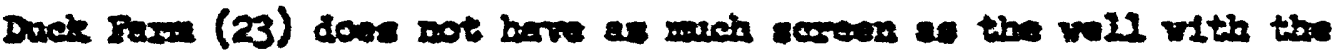

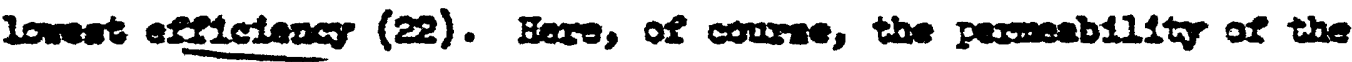

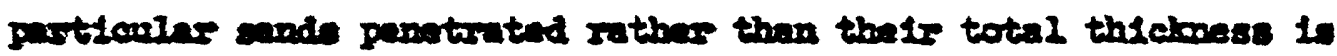
the cittenl suctor.

20 depp welle at Viltow Folnt and Stove Folnt end in the Iuttapous Formation (Spetion B-B', pl. 1).

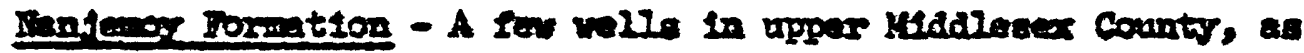

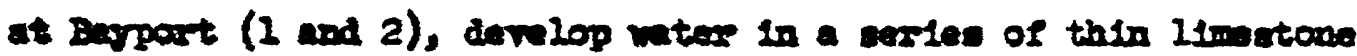
strata altedrating itth glawocostic quarts and pepetreted at about

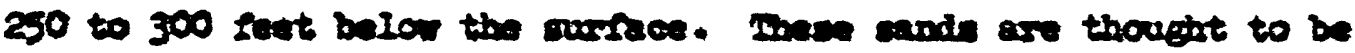

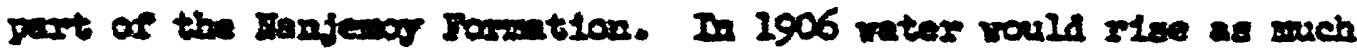

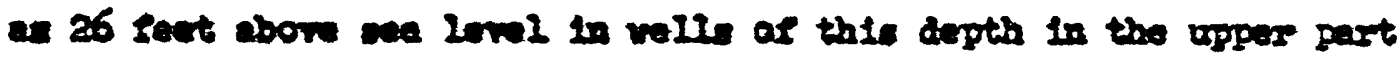
of the count (Basford, 1913, p. 318). Io 1arge now were reportad. 


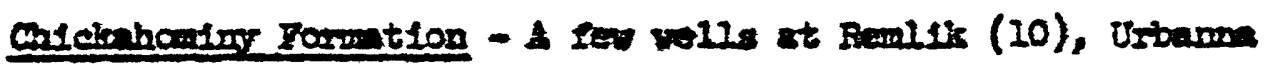

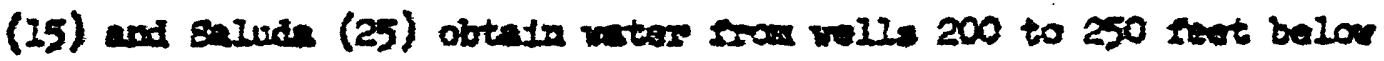

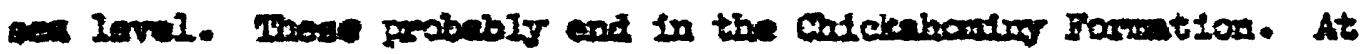

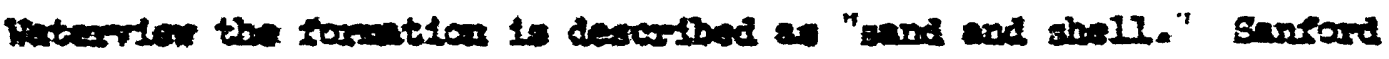

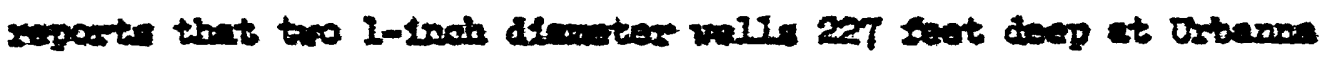

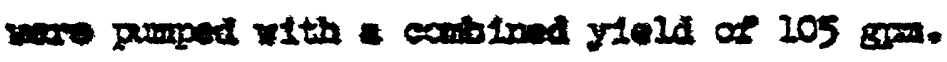

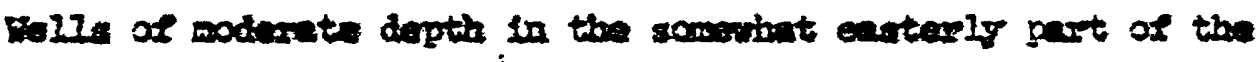

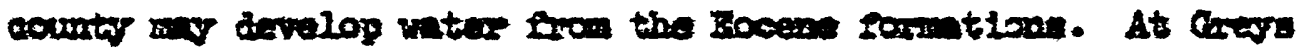

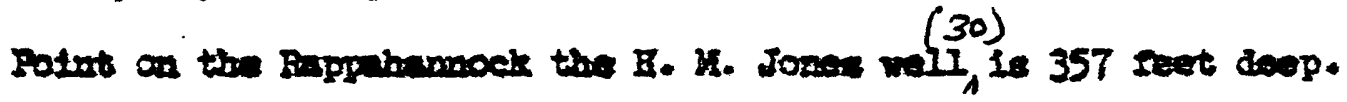

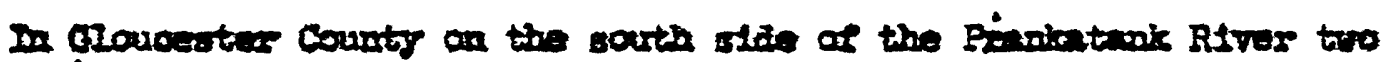
$(4,5,+, 6 b / 3)$

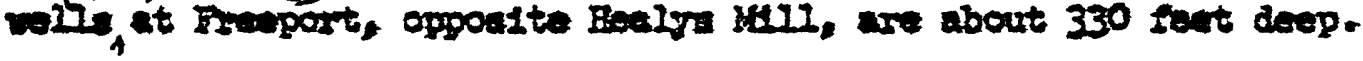

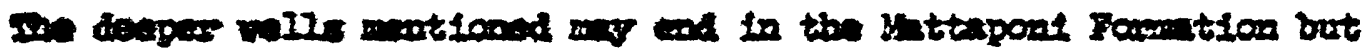

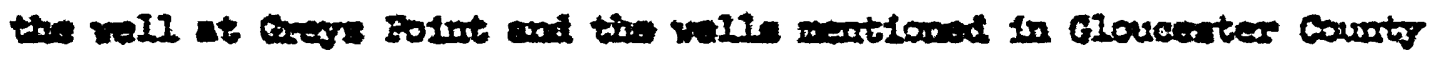

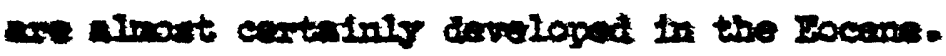

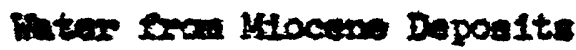

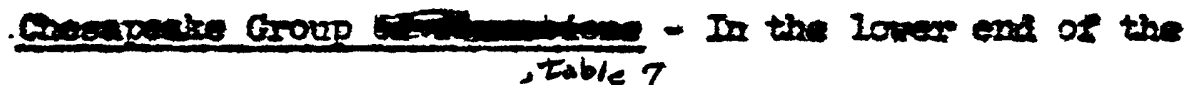

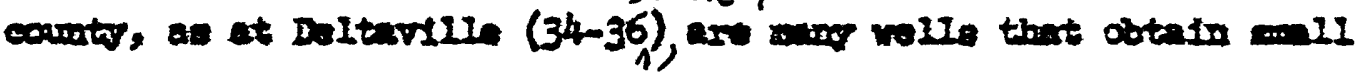

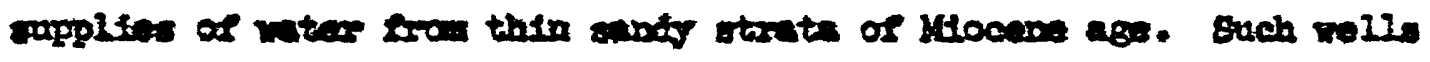
up be en little an 75 fent dewp or, lean comonly, as meh as 300 leat deap.

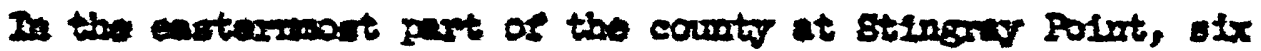

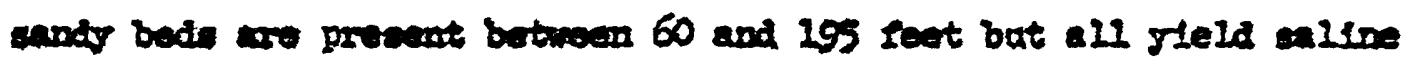

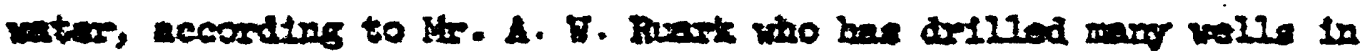


that area. In 1956, ist. Bruce lfoxwen of wallowton developed vater at 180 feet that was too solto to use (37) and further offorts to a donth of over 700 seot vere equally rrultleas. 


\section{Quaternary Systwin}

Water from Pleistocene Deposits

Water in quantities sufficient for household use is obtained from shallow wells throughout the county.

At Stingray Point where Miocene and older formations yield only brackish or saline water, larger quantities than tinat"yielded by one shallow well might be developed by pumping several shallow wells as a unit, skiming off eresh water from salty water below. The practicability of an infiltration gallery - a permeable tile or other collecting device laid just below the water table, would be determined by costs involved and ground available. Such a system might yield a few tens of gallons a minute as opposed to the very small yields available to a single dug or driven well.

\section{Quality of Water}

Water from the Mattaponi Formation

Water from deep wells in upper and central Middlesex County is a soft sodium bicarbonate type with a very low chloride content. In Remlik $(11$, table 9$)$ and Urbanna $(12,17,20)$ the bicarbonate content of the wells reaching the Mattapont Formation ranges arrom $500 \mathrm{mg} / 6$ the consentrationt of 47 but other constituents are low. Fluoride, however, ranges from 2 to $2 . t \mathrm{mp} / \mathrm{s}$ sight slightly more than the $1.5 \mathrm{mpm} / \mathrm{h}$ considered desirable for public supplies. It is particularly noteworthy that the chloride content of water from the deepest wells is very low. 


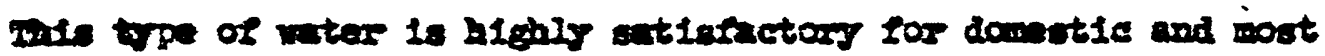

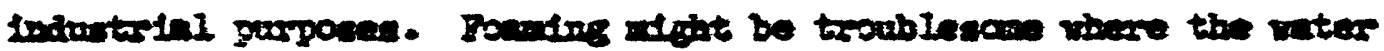

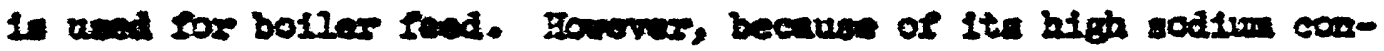

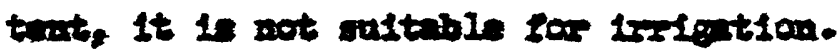

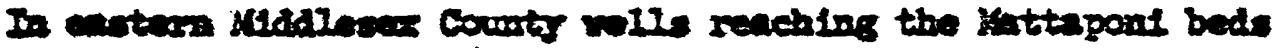
whter wian

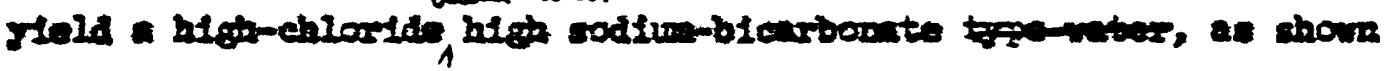
if the encleste (39, table 9 ). A mole taken in 1918 srom the

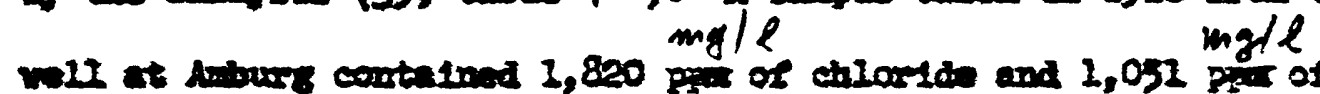

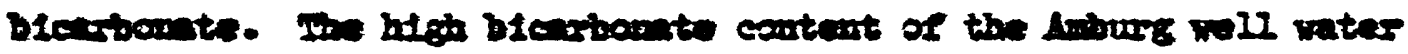

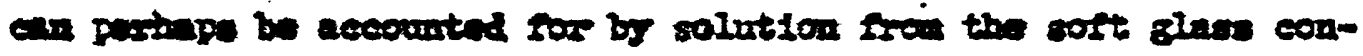

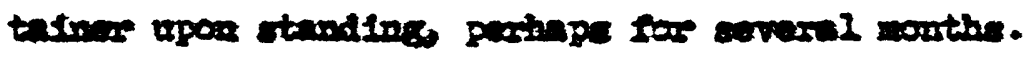

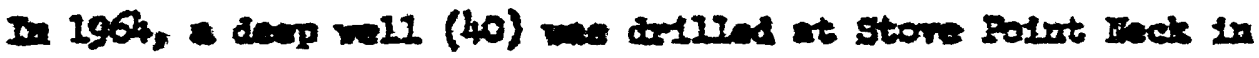

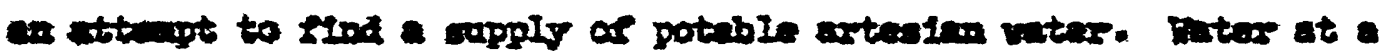

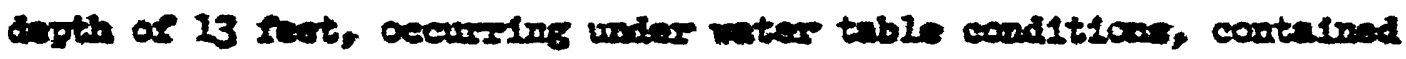

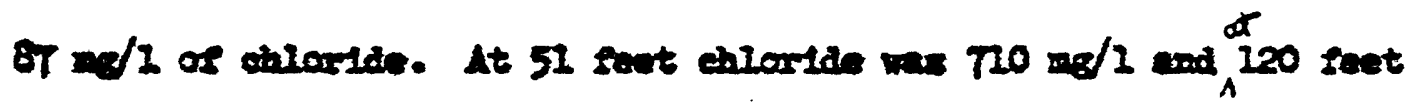

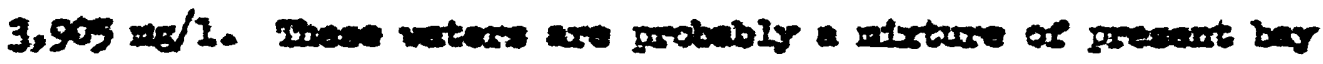

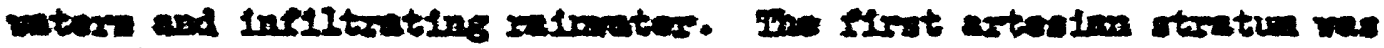
reachet

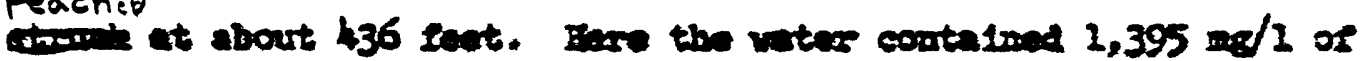

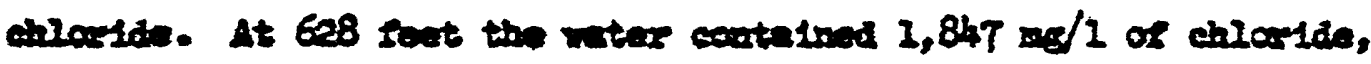

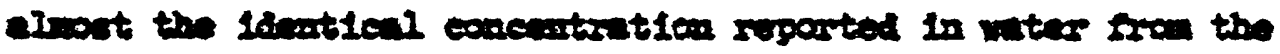
A.burs woll.

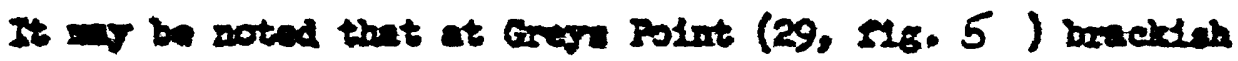

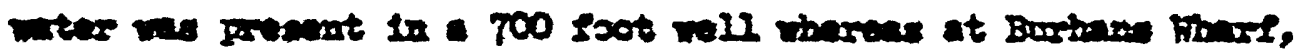

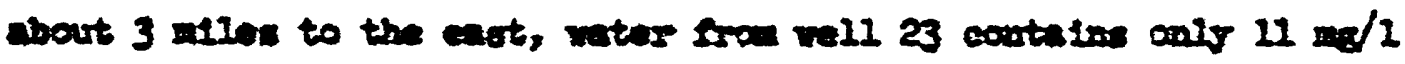

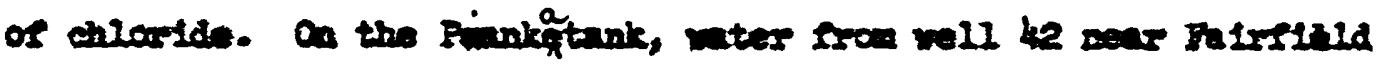




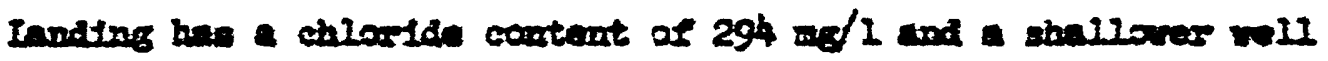

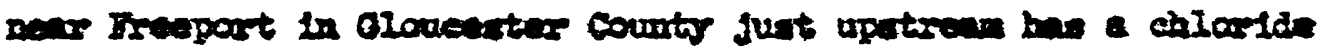

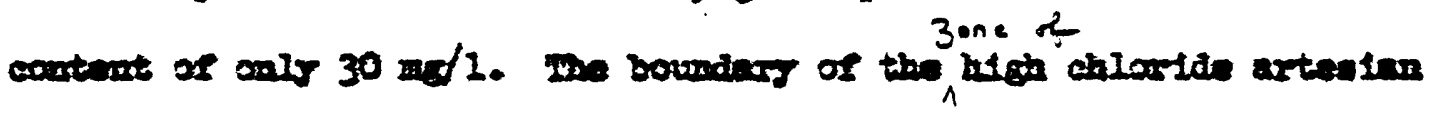

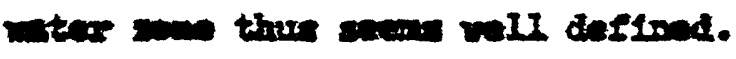

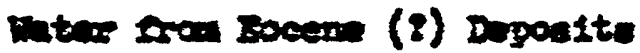

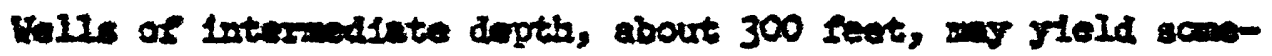

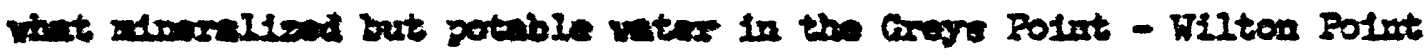

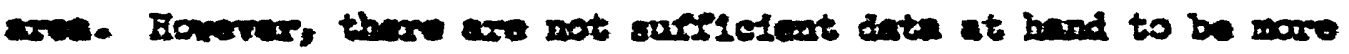
opectese in this sognd.

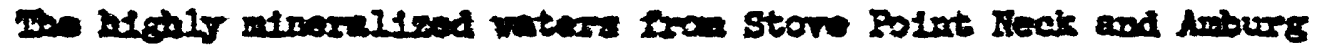

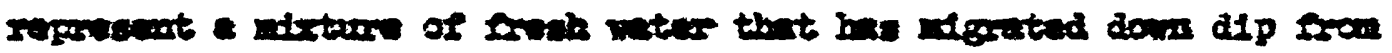

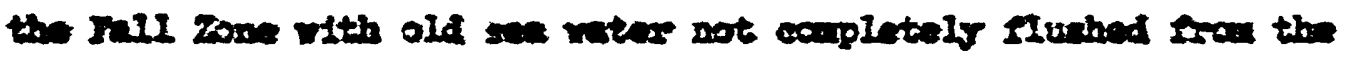

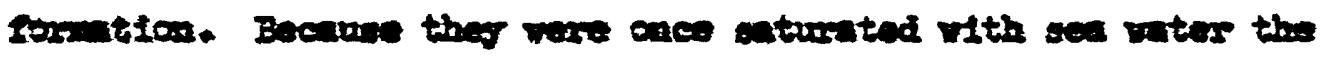

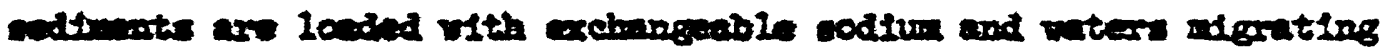

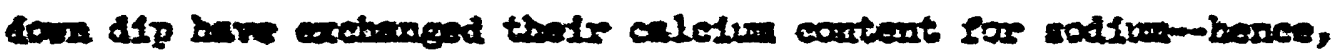

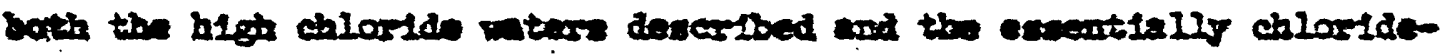

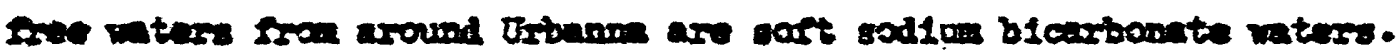

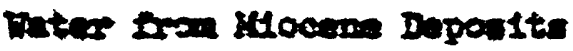

Dates srow three will at Deltarille (34-36, table 9 ) that

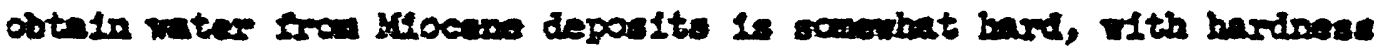

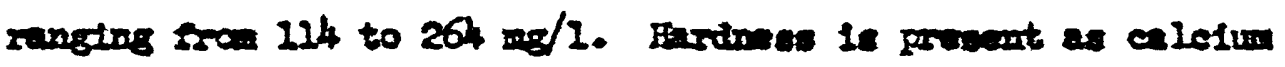

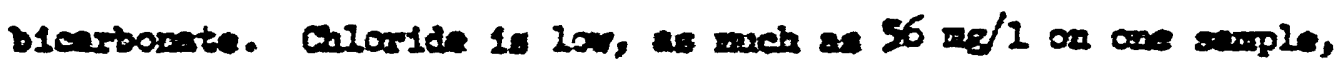
but onit $7 \mathrm{me} / 2$ in mother. 


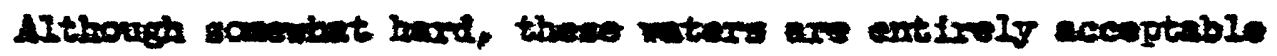

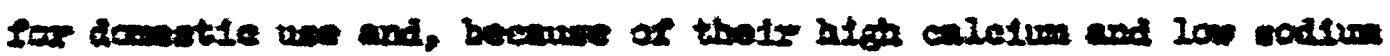

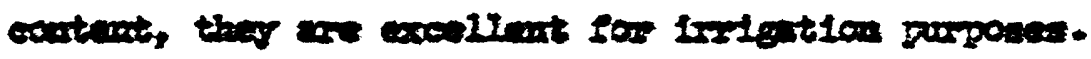

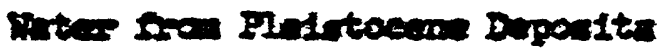

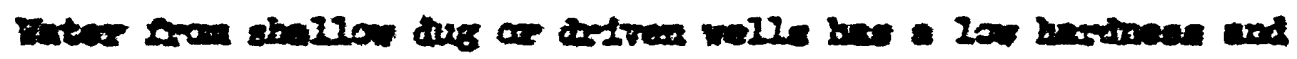

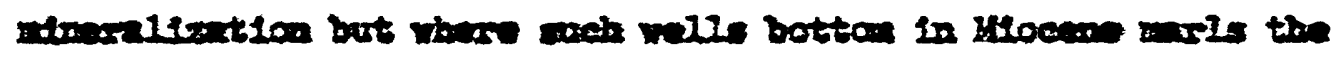

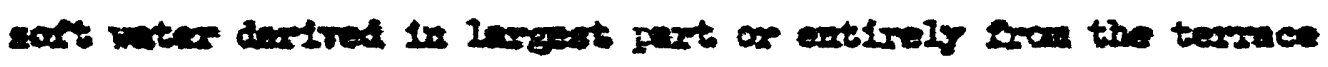

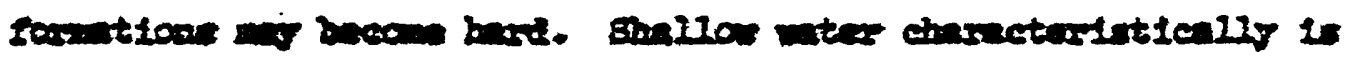

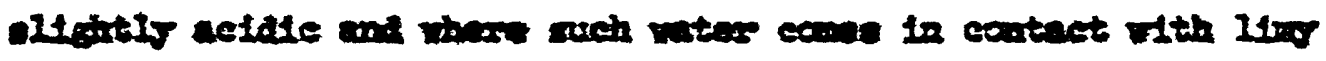

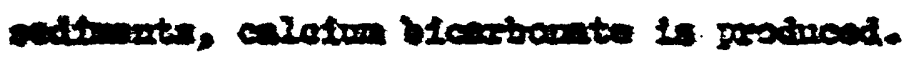


In low lying areas on the Chesapeake Bay where the only water available is from shallow wells, means of providing larger, more dependable and safer supplies should be considered in view of present heavy summer populations and probable increase in demands.

A trunkline bringing artesian water from a distant source up but the peninsula offers an obvious and expensive solution. However, before such a trunkline is justified and constructed, much might be done on a smaller scale through artificial recharge.

Where a central supply point for several villages is to be established, it may be practicable to recharge the deep brackish water artesian formations with fresh water from shallow wells. Much of the recharged fresh water could be pumped back as needed, uncontaminated by the brackish water, as explained in the general part of this report.

Shallow wells in the terrace formations can furnish a modest volume of water but reliance on that water in times of peak demand and low recharge would be both risky and expensive. However, where adequate storage is provided, as in the deep formations, the discharge obtained during long colder month seasons might easily satisfy the peak summer demand. If it be assumed that as little as 50 gpm were pumped from one or two shallow wells continuously and injected in a deep well for 9 months, 150 gpm could be pumped back in the following summer season, a volume sufficient for at least 1,500 people. Actually, since some mixing would take place, the return ratio. 


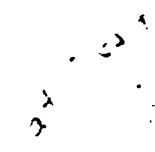

would not be as favorable as stated. The efficiency to be expected after injection is not determinable at present but there is every reason to believe the device suggested is worth considering. Obviously, a recharge rate ofí in excess of a hundred gallons a minute would be hoped for. A very few properly constructed shallow wells might supply the amount of water required with ease, most of the time. Economies in operation might be effected by recharging only at times when off peak power rates are available. Inasmuch as recharging would have to be done under some pressure (the artesian head is probably almost as high as the shallow water table), the most efficient operation would require that a maximum recharge rate at minimum head (power cost) be established. On the other hand, slightly higher costs might be accepted in order to recharge a greater volume of water. Since lifting water from a well and pumping to an overhead tank for recharging might involve as little as 50 feet of pumping head, the power cost would be low-about $25 \%$ per thousand gallons at I\& per kilowatt hour.

In some areas, water from the Miocene formations is also available: As noted above, where this is a very hard water, it may not be as desirable for recharging as the softer water from the terrace formations. The compatability of injected water with reference to the deep formations and possible clogging is one of the several aspects of artificial recharging about which little is known.

Asșuming that a recharge well was constructed and operated as sketched out above, there is no reason why water from the shallow 
wells, ending either in the terrace formations or in Miocene beds or both, should not be used in conjunction with water from the recharge well during the peak demand season. The shallow water supply might vary considerably accordin'y to recharge received from local rainfall but whether large or small, it could be utilized to the fullest exfent possible

and deep well recharged water utilized as makeup.

With respect to artificial recharge, the state of the art is such that specific recommendations cannot be made at this time. The purpose of the discussion given above is to point out the possibilities inherent in this device and the great savings that might be made by providing water locally rather than by trunkline from some distant source. The results of further work in the field of artificial recharge through deep wells will be awaited with interest. 


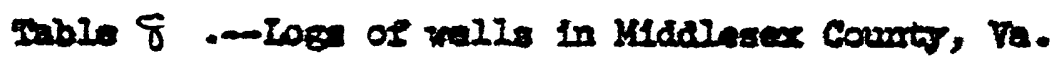

Nell 3 , H. B. Abbott, Natecolew

( log by Sydur Aydridynamics, Inc.) Altitude 5 soet

Dricteras:

(xent)

Columist Group (Pleitrocene)

send, rellow, eleves

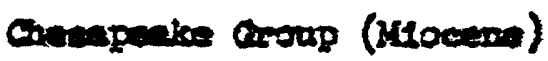

Ind, Blat

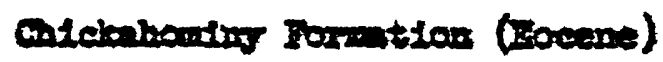

Sund, shalle, mat

sal, blo

$\infty$.

sand, bInek

gond, sow

gunt, condros

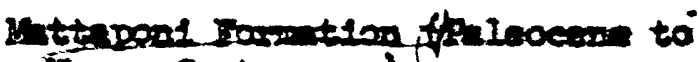

Upgex Cretaceove)

Qin, jeilos
38

$54 \quad 292$

$\begin{array}{ll}12 & 204 \\ 40 & 244 \\ 41 & 285 \\ 5 & 290 \\ 5 & 295 \\ 10 & -305\end{array}$

6

321

140

139 


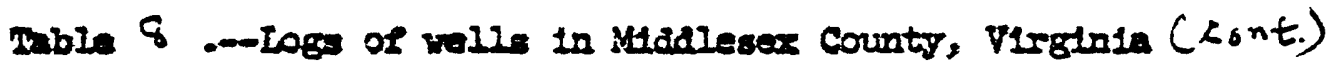

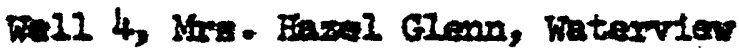

(IOg 0.c. 0 )

Altitride/ \& peet

Thickness

(feet)

Deptb

(feet)

Columbin Group (Pletatocene)

sind, yel10

30

30

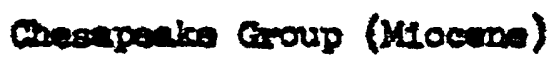

Qne, blow, sands,

270

200

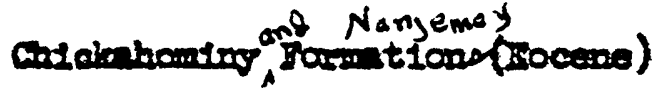

Bhall and sabd; vaters

40

240

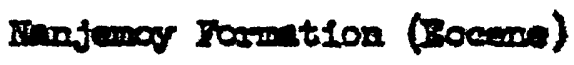

gbell roek formation and black and white sind

55

295 
Table 8 . - Ioge of volle in Midalewex counts, Pa. (cont.) Disil 6 , J. B. Jackeron, samon

Altitudez's ect

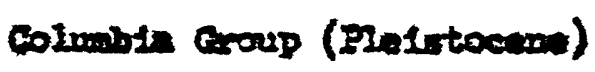

Gro, Jellor

20

20

sand, conces

30

50

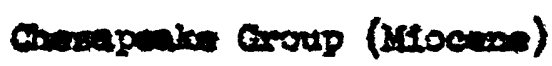

ores, dont

102

152

sand, tine

8

160

cing, ande

56

216

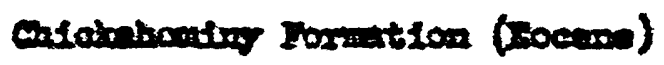

sund and ablis nter

20

236

Boot and shell

6

240

sand, cirs and obell

25

265

sund and sbell; vater

37

302

Book

4

306

sand and abel1

13

319

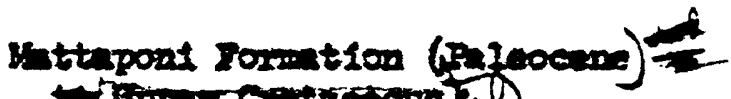

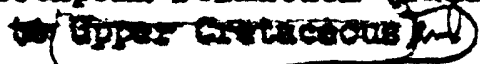

ar

256

475

sund

50

550 
mable 8 . - Loge of welle in Midalesex County, V1rginis (cont.) wil 2 , waltax same, urbann

Clog by MoteteUs Pungs

Ondescer lbed Depteioness
(feet)

40

40

Chesepolke Croup (MLiocono)

Cley, bleck, and shell

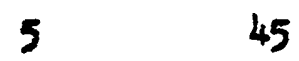

Cing, blue

125

170

Blay, blus, sbell at base

$40 \quad 210$

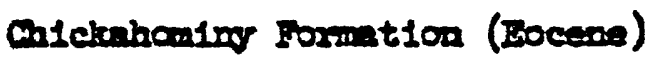

Sund and sholl

2

212

sund and clay

Bocis:

2

222

Band; water

23

245

sund and rock, elterrating

18

263

sund and shell

5268

Rock and sand, alternating

16

285

manjemoy (8) rormat1on (Bocene)

suad, bleck and whito

Bund, black

40

340

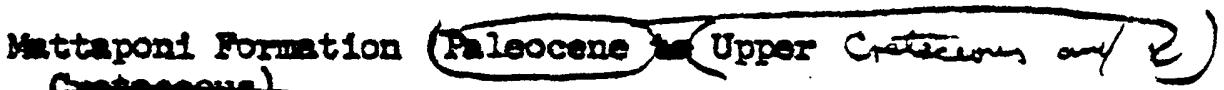

Gomencount

sand, Black

60

400

Bund, black, minor clay

$20 \quad 420$

sand, black and wito

54

474

sand and gravel, wh1to

13

487

Jote: Much of black sand belon 340 feet may have washed down sram above. 


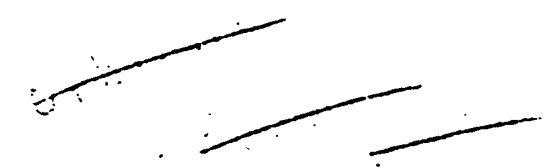

Table 8 .--Iogs of wells in Middlesex County, Virginia (cont.) Well18, Municipality, Urisand, Remlik(Loğ from Va. Div. Mineral Resources files)

Altitude $2 \theta$ feet

$\begin{array}{cl}\text { Thickness } & \text { Depth } \\ \text { (feet) } & \text { (feet) }\end{array}$

Columbia Group (Pleistocene)

Sand, fine

Chesapeake Group (Miocene)

Clay, green, with shells

37

80

Clay, gray

144

224

Chickahominy and Nanjemoy Formations (Eocene)

Shell rock, shells, gray and black sand and clay in streaks

73

297

Nanjemoy and Mattaponi Formations (Eocene to Upper Cretaceous)

Clay, gray, hard

145

442

、 Clay and black sand, in streaks

12

454

Clay, gray and pink

24

478

Sand, gray

16

494

'Clay, mixed colors

34

528

Clay, hard, tough

29

557

Sand, gray, some black

18

575

- Clay

Sand, gray

Clay

601

Sand, gray, coarse

Clay, red, gray and brown 


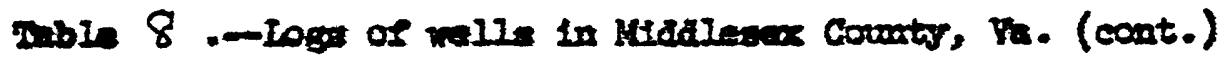

Nall 20 , Hes. S. Is Stramon, Urbam

Altitade 15 seat

Defoikneasth
(foat)

collumbin Group (Flestacina)

Band and grel

22

21

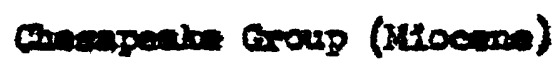

Cis?, $\sin$

207

227

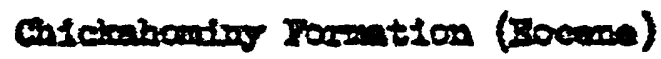

shell and olay, in etroales

23

245

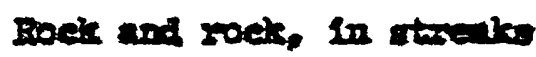

58

303

Clor, grem, sema struiks

22

325

lattapent Foryation (Ptilocome to

Opperer Grotaceoves)

Fot inseriond

55

380

cos, $\sin$

68

448

sund, gor and brons, and abolis

11

459

chay,

16

475

sund

7

482

$\cos y$

18

500

and

6

506

clay

39

545

sand

20

555

Cor

23

568

Sund, gras, modium to courses water

12

580 
mole $8 .-$ Loge of vells in Midaleser county, ph. (cont.)

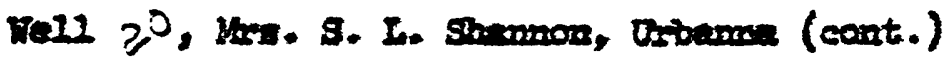

\section{Atude-}

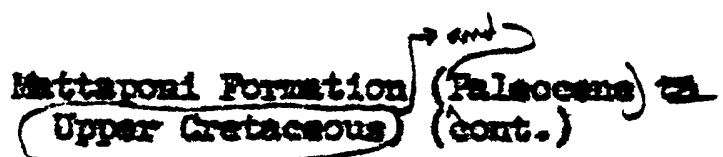

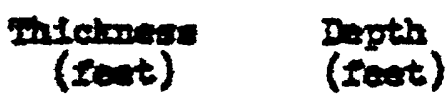

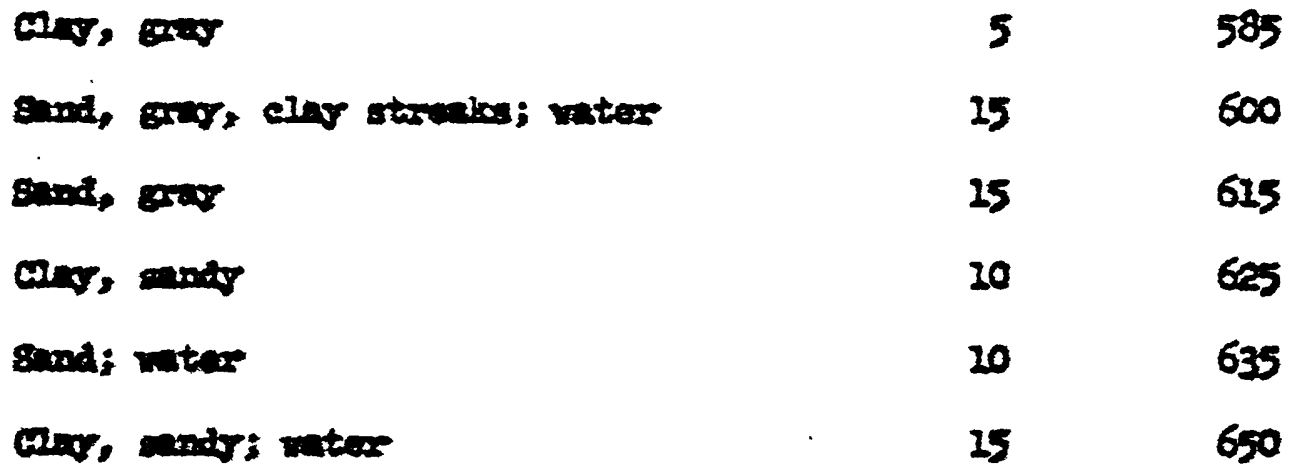

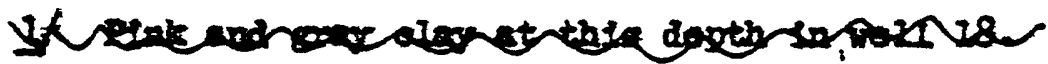

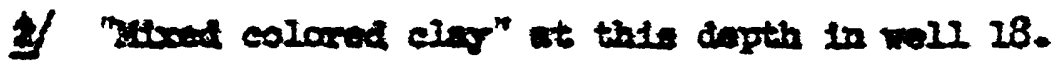




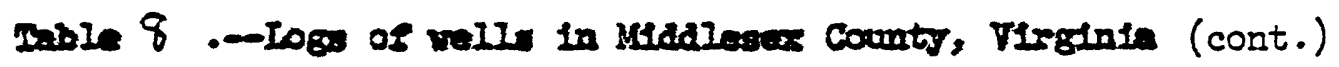
vell is, tow of selude, Virginte

(Log by stoos Promp a bell Co.)

Altitude 95 sect

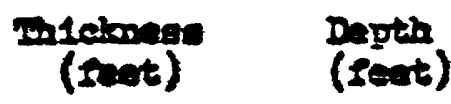

colmible Gorup (Fle1stocan)

ans, rallor

Dond, vitte

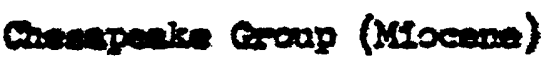

Cis, sand, gellow

sond, bard, eine

Clar, Jellor, ands

Band, bard, 2100

Clor, ors, and shells

sand, bard, 1100, and shello

Clos, ors

Clos, gumas, green

Clas, oras

Book, brown

Orv, aros, and shollo

culderabonisy pormation (zocene)

sand, entris course

sand, line, bard

Clar, soft, green
30

18

12

60

10

To

4

74

23

97

2

99

25

124

130

254

24

278

19

297

1

298

1

299

16

315

9324

6
30

48

60

0

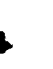


rable 8 .-Toge of velle in Middlesex County, Virginie (cont.)

Vell 28 ...R. B. Pexritt, Burbane moers

Alt1tude 32 feet

$\begin{array}{ll}\text { Defeet) } & \text { Depth } \\ \text { (feet) }\end{array}$

Collubin Group (Pleletocene)

Sund, brown to walte

60

60

Orempeabe Group (MLlocene)

sand, blue, flne; rater

30

90

sund, rellow

5

95

varr, blue

233

228

Onteinhoutios Group (Eocenc)

$\cos , \cos$

grall, and, mudds, hard streake

nuttapont pormation (Faleoceng) to

Opper Cretacoound

sand, black

sholl rock

sand, black and shell

senell sock

sand, bleck and abell

Clar, gras and bleck sand

Clos, gras

sund, gov; reter

sowell roct

Sani, gon; vater

Rock
80

44

13

2

5

3

18

50

62

8

7

4

3
308

352

367

5 372

3375

8393

$50 \quad 443$

62505

513

520

524

527


mable 8.--ioge of Welle in Midaleasen County, Va. (cont.)

Hell 40, Stove Potrt Hock Development

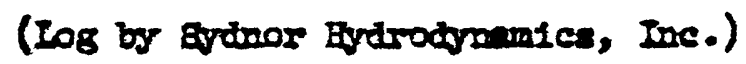

Altitude 5 reet

$\begin{array}{ll}\text { Dhtokongs } & \text { Dopth } \\ \text { (foet) } & \text { (feet) }\end{array}$

columis Croup (Rlalotocane)

sand, vistal veter

28

18

sund and ablils; weter

4

22

Cresepealce Grous (Misocone)

env, blue

31

53

CIns, blue and shalls

$T$

60

shells, consese

13

75

Sand and she21s; vatar

8

83

sund, ges and grem, fines water

36

119

sum, enven, stlty and elever

24

143

ons,

64

207

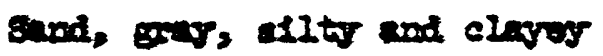

15

222

CDes, gras

16

238

Cor and andite

7

245

65

320

Onfelowhontuy (8) Formation (Locena)

mos, exem, aflty

20

335

Cing,

101

436

Sand, black, same shells and clay, sharke toeth; rater

21

457

Mattapon1 (1) Formation (Paleocene to

Upper creteceous)

Con, erean

43

Clay, gory, somells

15

500 515 
mable 8.-Logs of pells in Medalesen County, Fe. (cont.)

Well 40, stow point Back Development (cont.)

Deploposen
(feet)

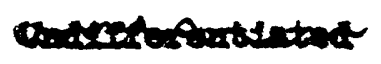

ciner, oras, tough

81. 596

$\sin ($ (?)

$2 \quad \overline{598}$

cros, ores

$29 \quad 627$

Cor and, hard, seme elor; rater

8635

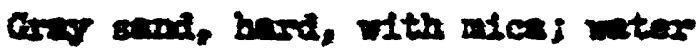

$15 \quad 650$

sand, ow, consse; rater

$17 \quad 667$

send, exp, 1100,

$22 \quad 688$

Sand, gers, conroes noters

$8 \quad 696$

Clog,

$12 \quad 708$

sand, orv, bants vater

It 202

surd, ors, sort; vater

64 786

sund, elores

$3 \quad 789$

Clor, gor, tard

3792


Table 8 .--Logs or vells in Middiesex County, Virginis (cont.) well 41, C. Euss, Thisge Ferry, Wilton Polnt (Iog from Va. Div. Mineral Resources Flles)

Alt1tude 20 leet

$\begin{array}{cc}\text { Thickes8 } & \text { Depth } \\ \text { (feet) } & \text { (Ieet) }\end{array}$

Collumbia Group (Plelatocede)

Subso:1

Chesapenke Group (M10cene)

cles, blue

Sand and shells $2 \quad 27$

Clay, blue 18

45

Sand, green, and clay 18

Clag, light blue

10

To

Shells

stone, soft

Blue to tan to blue formation

165

255

soepgtone (hard clay)

Ondifferentiated

Clay, ereen

151

415

Undescribed

Stone; some vater at 460 feet

Undeacribed; brown elay at 700 feet

240

700 . 


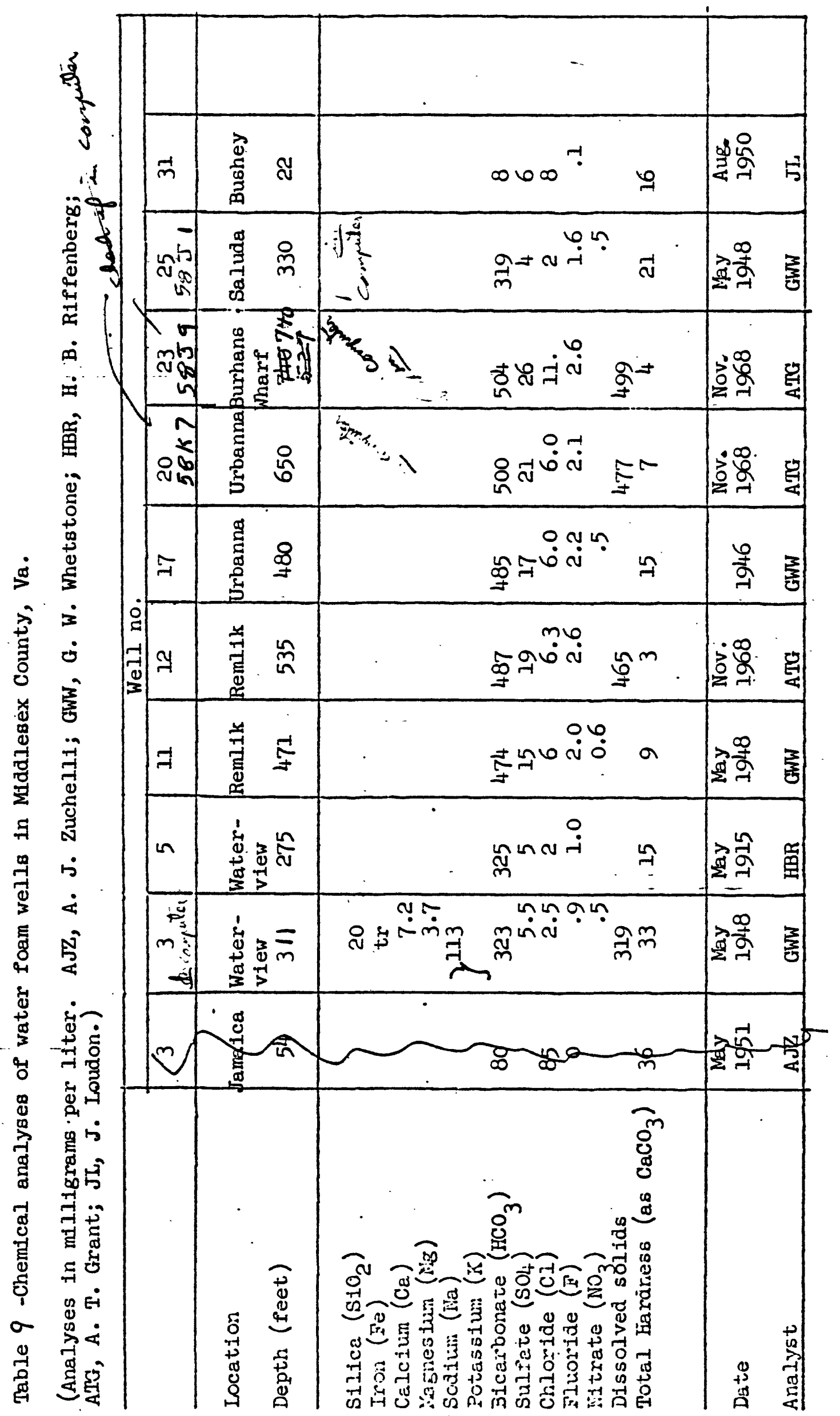




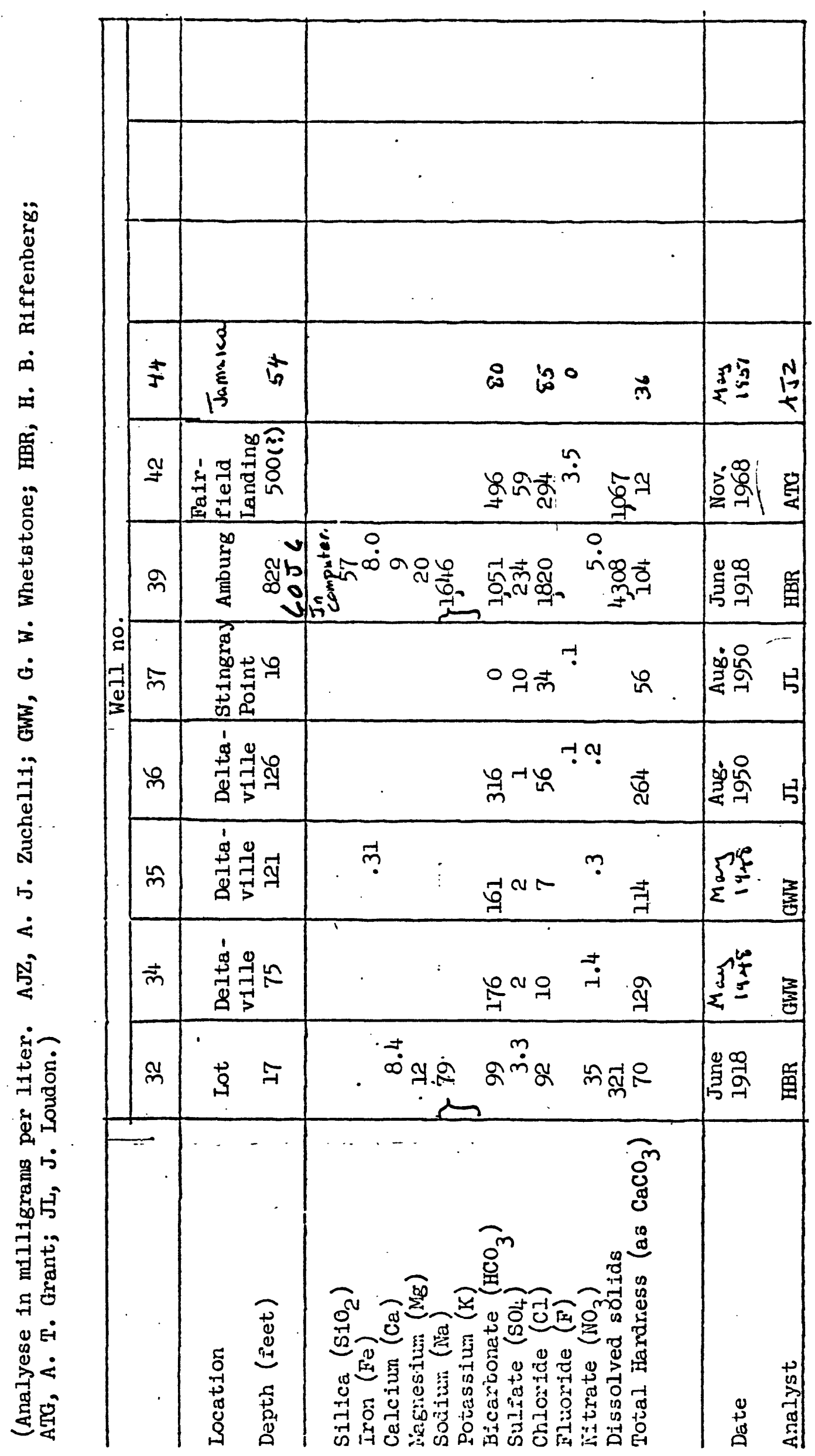




\section{Ling and Guean Countr}

Introduct 1on

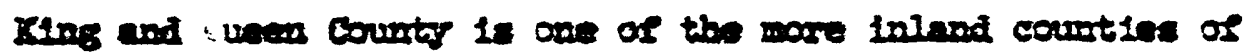

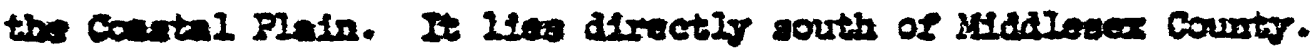

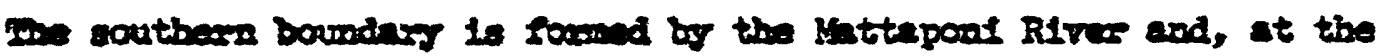

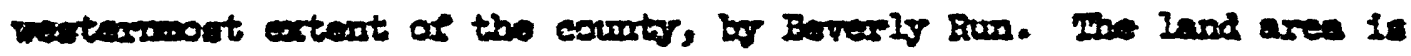
290 agure niles. population in 1964 ins 5,617 .

2he popaletion is entirely suril. About one-fourth of the

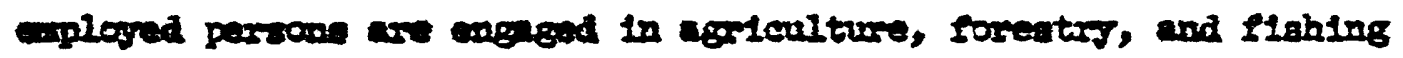
and about an wow aro explaved in monemeturelng. Nar of the latter

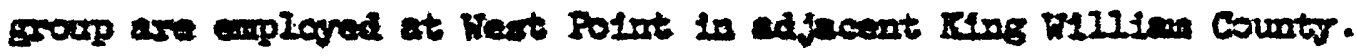

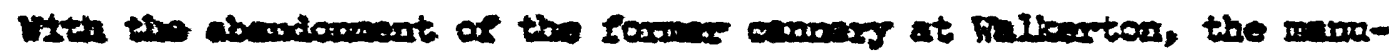

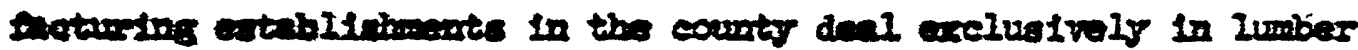
and biste lumber proatrete.

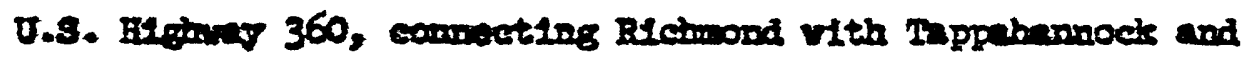

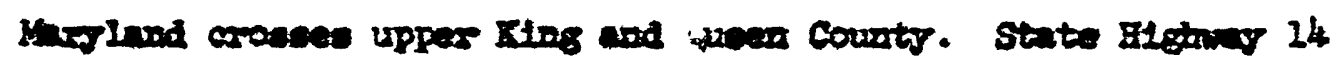

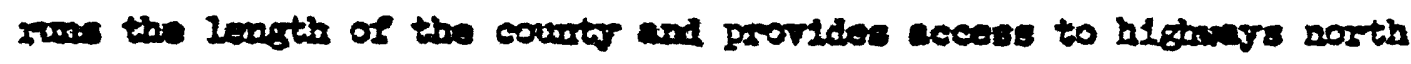

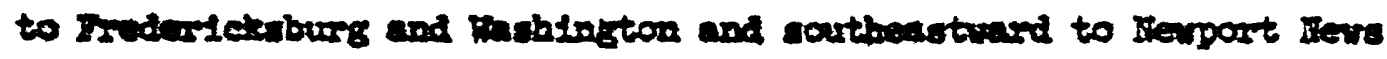

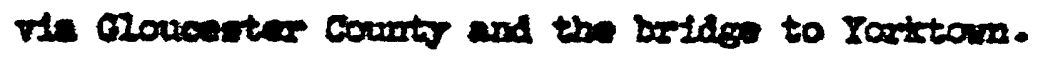




\section{Ceologs}

Bencionent Bock

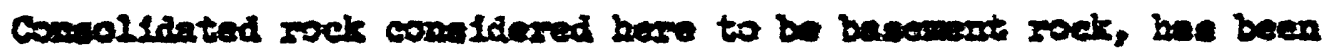

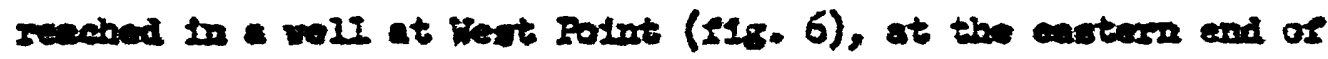

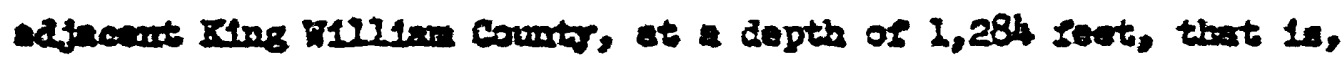
about 1,260 foet belon aen level. At Borling Geed it was roached at about 260 fout belos sen level. Jence, as hown in section B-B',

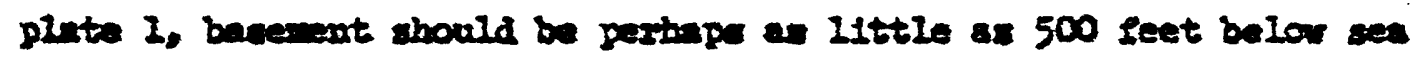
Iowel in uppar king and Oumen coint and wore then 1,300 feet below we level at the loves and as the county.

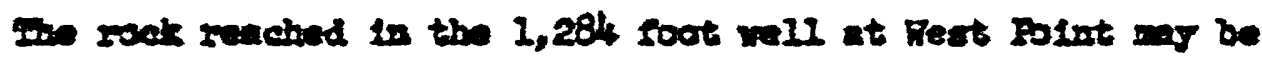

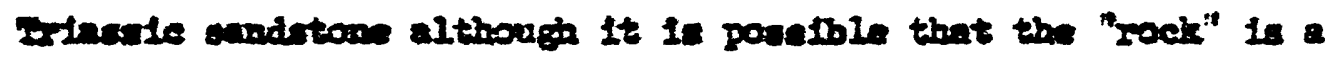

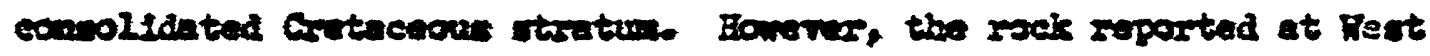

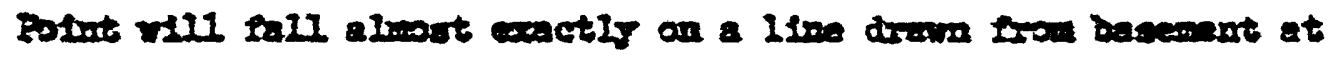

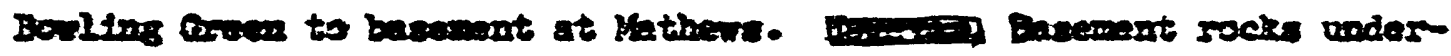

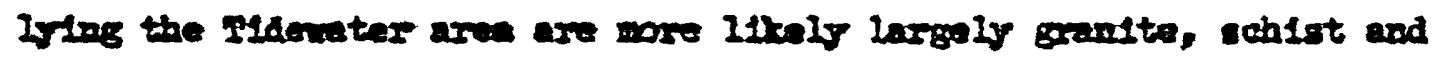

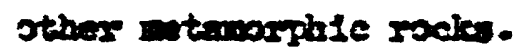

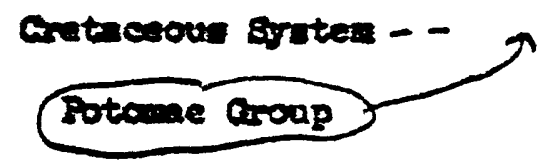

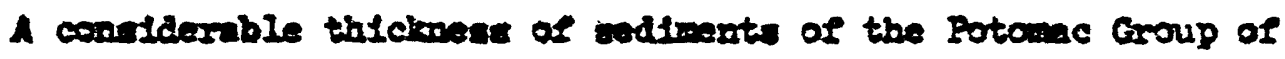
Faris areticeors age was panetrated in the deep well at Hert Bolat in adjucent King $\nabla 11110 \mathrm{~m}$ county. Whese conelot of altermating and and clar bede. Al seen in the croas section, the boundary between the orerlying Nattaponl Powntion and the Potane Grap is conjectural. It seven $21 k=1 \mathrm{y}$ that the thick rands above 


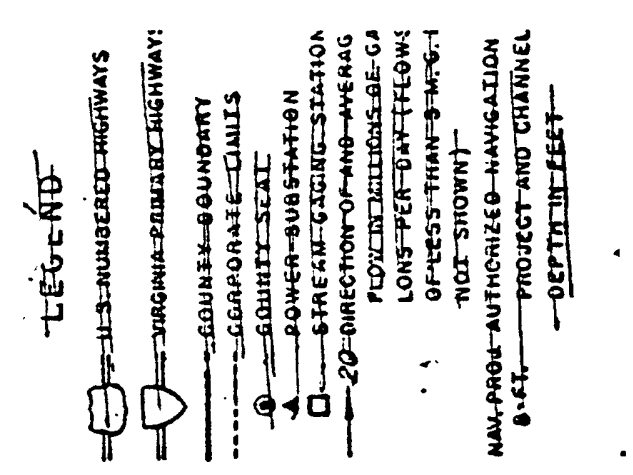


depth of 800 feet are basal sands of the Mattaponi Formation rather than Potomac sands. If so, the Potomac section is about 500 feet thick, of which the lower 200 feet is very sandy. ${ }_{1}^{\text {Mtherigh }}$ Potomac group underlie ${ }_{A}$ oll of King and Queen county, they hare his not been reached by any wells, as far as can be determined.

Cretaceous to Tertiary Systems

Upper Cretaceous to Paleocene Series

Mattaponi Formation: The Mattaponi Formation is of date Cretaceous and Paleocene age. It is characterized in its upper portion by glauconitic sands and clays that are not greatly different from overlying Eocene beds in many places. The lower part of the formation is characterized by highly colored, variegated or mottled clays, sometimes termed "rainbow clays" by the driller. These beds are non-glauconitic or only slightly glauconitic. Thick sands occur at the base of the formation at West Point where the Mattaponi section is considered to be about 500 feet thick. ${ }^{\pi}$ The . higher beds in the Mattaponi Formation, are nondescript clays alternating with glauconitic and quartz sand; and the underlying mottled clays have been penetrated in wells in the Stephensville - Walkerton - St. Stephens Church area in King and Queen county. wells there penetrate only, the uppermost pof of what is considered to be the basal sand section; has bin penatister 
Aquia Formation: The Aquia Formation is of Paleocene age but at the type locality on Aquia Creek and for some miles eastward ${ }^{2}$ is characterized by a foraminiferal fauna that is different from that of the underlying Paleocene strata. Studies in the (Cederstrom, 1957, P. 26) York-James Peninsula show that the Aquia Formation thins to a vanishing point downdip. It is thought that in King and queen County it does not extend much farther downstream than Walkerton.

The Aquia is made up of blue clays and minor sand and is highly glauconitic, as are the overlying beds of the Nanjemoy Formation.

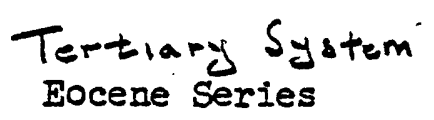

Nanjemoy Formation: The Nanjemoy Formation of Lower and Mfddle Eocene age is made up of highly glauconitic sand and marl beds. It is exposed along the Mattaponi River upstream from Aylett but is reached at a depth of about 200 feet below sea level in the eastern end of the county. It is more sandy than the underlying Aquia and commonly has intercalated thin limestone strata. To a pink to brown clayt from jlace to place
the base. brown clay reported in the log of well 18a (Table II) at Walkerton at 120 to 140 feet below the surface is considered to be that distinctive stratum.

The maximum thickness of the Nanjemoy is about 110 feet in this county. In the upper end of the county it may be thinner etosion before due to the overlap of the Miocene formations. In the lower end of the county it is transected by the overlying Chickahominy Formation and there 1 t begins to diminish in thickness. 
Colchahominy Format1on: Beds of late Bocene age, maned the Antakahoming Formation in Virginia, are present only in the enatermost part of the county. Dentalins bevan1, a bighly disnoatle formintfor, has been recognized in cuttings from Heat Polnt. Bowever, the formation ia undoubtediy very thin at Feat Polnt and It is not show in published loge of wells there (Cederstrom, 1957, p. 101-103). "Dirty sand and stone" and "gand and mud" from 243 20248 feet penetrated in a well at stuchelfords Fork way possibly represent the Oatchabontror.

\section{MLocne Seriea}

Chesspeake Group: The Chesapeake Group of formetions conslats of gray to blwe marls and clags and subordinate fine sand beds.

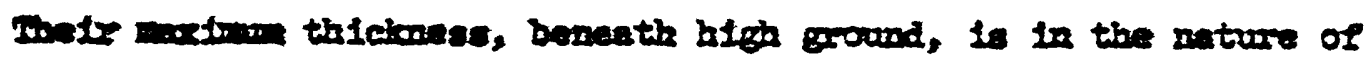
200 sent. Howrer, on low exound along the Mattapons hiver above

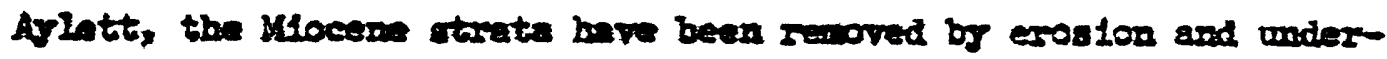
Iring Focenc bed are exposed at the surface.

\section{Quatearaty Brstem}

\section{Rulutocon Seriea}

Colindia Group of formation of Plelatocen ape ocen as terracea

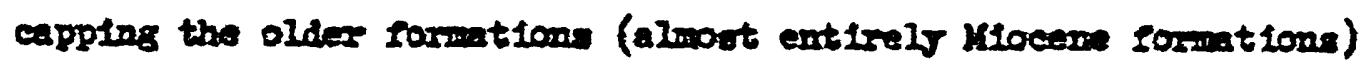
throughout the counto. Along atreeme and rivers erosion hes cut through them and onf the underlying Mocen bed aro present.

The terrece formetlon axe made up of vargling degrees of generally jellow elaye and quarte sands. 


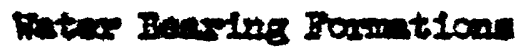

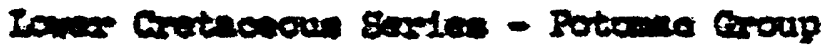

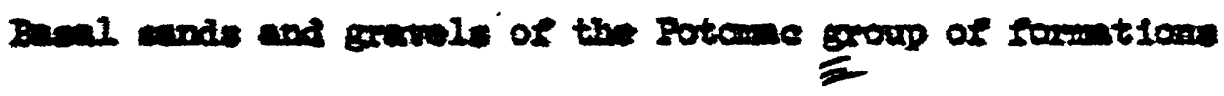

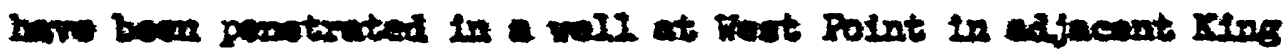

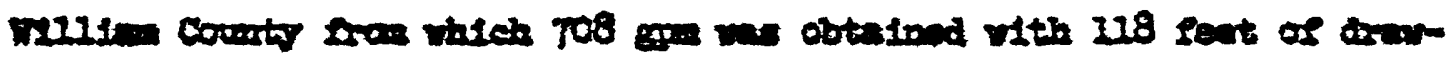

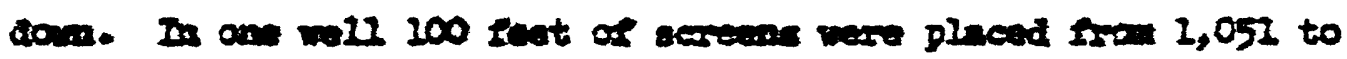

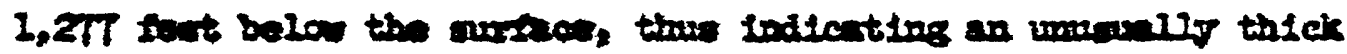

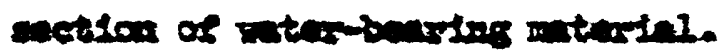

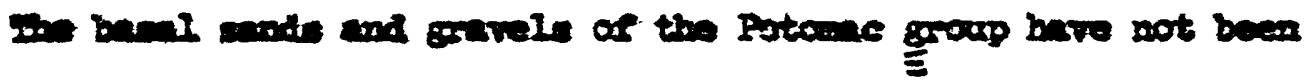

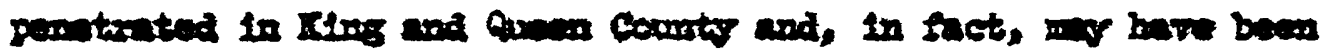

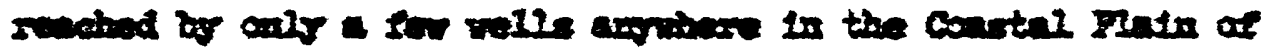

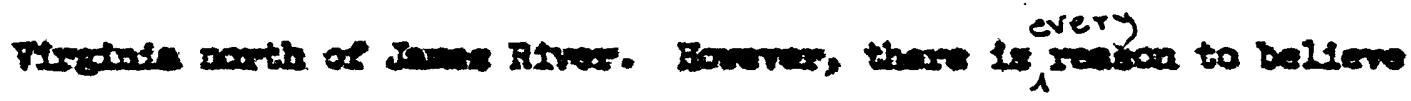

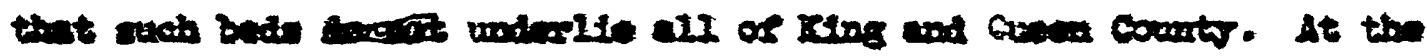

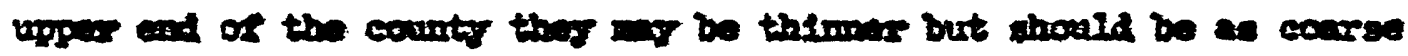

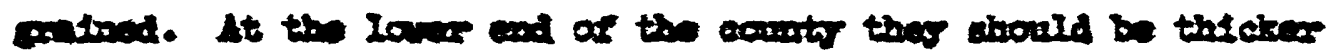

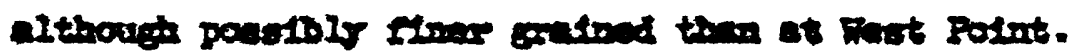

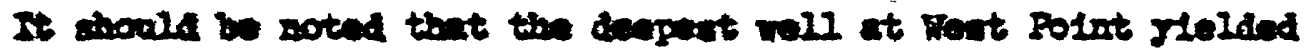

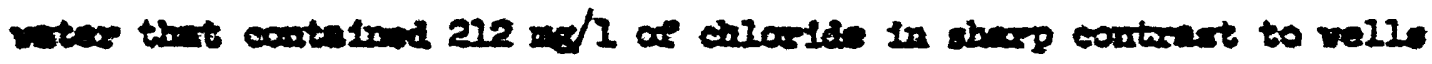

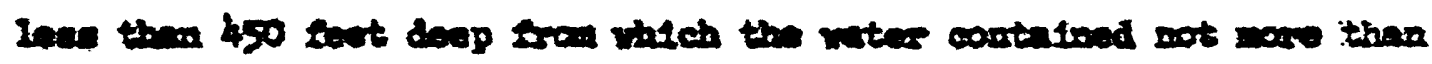

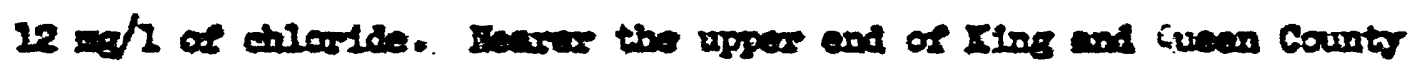

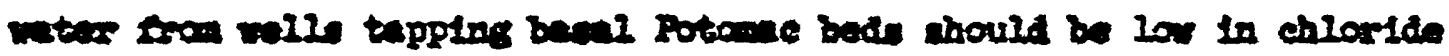

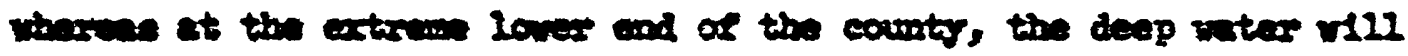

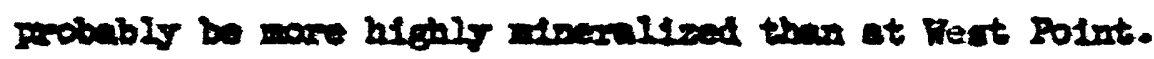




$$
\begin{aligned}
& \text { Cretaceovs th Thetiairy Sy stims } \\
& \text { Upper Cretaceous Paleocene Series }
\end{aligned}
$$

Mattaponi Formation: About 200 feet of sands and gravels and subordinate clayey beds are considered to mark the base of the Mattaponi Formation at West Point. One well 699 feet deep yields 900 gpm with 75 feet of drawdown (Cederstrom, 1957, p. 97).

In King and Queen County wells more than 350 feet deep near Aylett (1), Walkerton (22, 18, 19, and 21) and Stevensville (4) and at Roane below West Point (52) penetrate the upper portion of the basal Mattaponi sands referred to above.

The largest flow from any deep well in the county (11, Table 10) was 35 gpm as of about 1906 (Sanford, ${ }_{1}^{\text {'9.' }}$, 203). Well $18 \mathrm{~b}$ at Walkerton, drilled in 1926, had a flow of $45 \mathrm{gpm}$ and well $18 \mathrm{c}$, drilled in 1939, flowed $30 \mathrm{gpm}$ and yielded $150 \mathrm{gpm}$ to a suction pump. Both wells $18 \mathrm{~b}$ and $18 \mathrm{c}$ are 3 inches in diameter and are equipped with screens, the latter having had 10 feet of \#40 slot screen installed. However, it may be noted that a 3-inch well drilled in 1927 near Aylett in adjacent King William County is reported to have had a flow of $200 \mathrm{gpm}$ at about 10 feet above sea level at the time it was drilled and another 3 -inch well drilled nearby in 1939, also tapping basal Mattaponi sands, had a flow of $150 \mathrm{gpm}$ (Cederstrom, 1957, p. 96). 
Ime praped well of highest yleld in the county (IBd) is that irilled for the now defunct cannory at Wellerton. Ials well is equipped with 40 feet of sarean and yielded 233 gpm with 239 foet of dxundown. Ine alot atzas of the serven installed (25- and 30slot) suggests that the water-baning sard is a wdium-grasind and.

As notad, vary high ylelds have bean obtained at west polnt

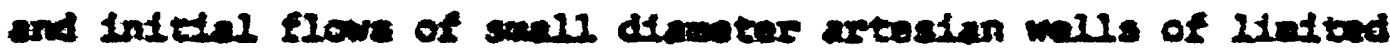

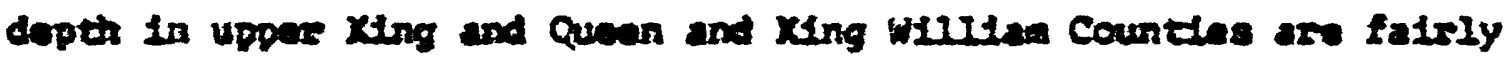

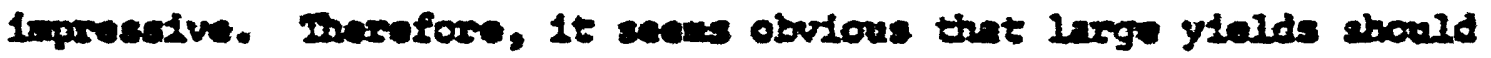
be avaliable troa properly constructed and developed deep wells

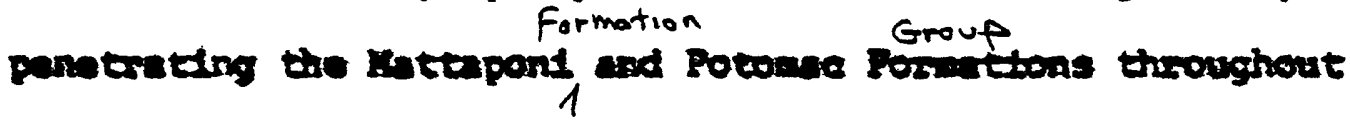
practerlly all of xing and quare county. 
At the time of sanford's surves, around 1906, the helght to which rater in the deep artesian beds would Flse was 35 feet or so above high tide level, in the central part of the county. In 1943 it rose 15 feet abowe aed level at walkerton.

A larger muber of welle (23, 12-16, and 6-10) and in quartz or qunte and glaucontte sands higher in the Mattaponi section at depthe genarrily ranging trom 225 to 285 feet. These are located aloug the Nattapont River from Aylett to Walkerton.

Io Inrge flow bav been reponted from these walls. The mactum reported (well 16) vas 20 spm but most of the rells had - mach aniles flos. The artealan head in volls in this depth range appaars to be about the same as in the deeper wells. Prermably good ylelds, eay in the anture of 100 gro, could be obtalned from som or mas of these vells vere thes of somewbat larger Alamoter than 2 inches and equipped vith sereen.

\section{Tertiary syotem \\ Puleocene Bertes}

Agate Formation: It is not certain that any wells in the county end in the Aquia Fosmation. (Bee Section B-B', pl. I).

\section{Docene Sertes}

Panjemor Format1on: Trelvo wells (32, 42, 29, 30, 34-41) at Ling and Queen Court House and at least one at Mantapele (25) and at Iftitic Plymouth (43) end in sands of the Fanjemoy Formation at a depth of about 150 feet belor sea level. The sands are glauconftic to some degree or, in places, all glauconfte, sand, fine in texture and commonly thin. The artesian head was never as 
high as tim in deeper wells, only abqut "23 feet above river level, and flows were generally small. Sanford mentions an old well at King and Queen Court House (38, Table 10 ), 216 feet deep and arilled in 1889 , that had a small flow at an elevation of 23 feet above high tide but which, in 1906, had lost head to the extent that it had to be pumped. The greatest flow reported in 1943 from Nanjemoy beds was 12 gpm (we11.32) but well 416 was said to have been pumped at a rate of 20 gmo. Because of the low head, sands in the Nanjemoy are not developed by wells in many places. However, the formation appears to be an excellent and economical source of water for domestic use and could probably be developed in other parts of the county.

Chickahominy Formation: Many of the old wells mentioned by Sanford (1913, p. 210) 110 to 120 feet deep at West Point end just about where thin beds of the Chickahominy Formation would be expected to be found. The well (50) at Gressitt, according to Sanford (p. 3I0) ends in rock at 206 feet. This appears to be the thin limestone and sand sequence characteristic of the Chickahominy elsewhere. The old wells at Roane (53) and Belleview (51) are of much the same depth:

\section{Chesapeake Grou? - Miocene Series}

No wells are known to end in Miocene formations in King and 1

Queen County, nor in the adjacent more highly developed West Point area. 


$$
\begin{aligned}
& \text { Quatornary } S y \dot{s}+\text { m } \\
& \text { Pleistocene series }
\end{aligned}
$$

Throughout the county are many wells up to about 40 feet deep that obtain water from the terrace sands. Only quantities sufficlent for domestic use have been developed as far as is known. 


\section{Qunitio of Raters}

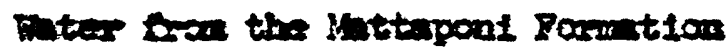

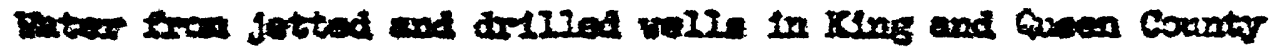

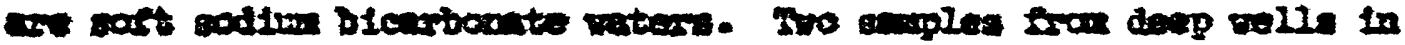
(table 12)

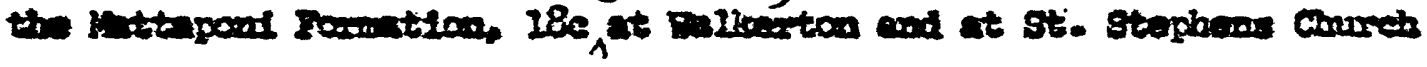

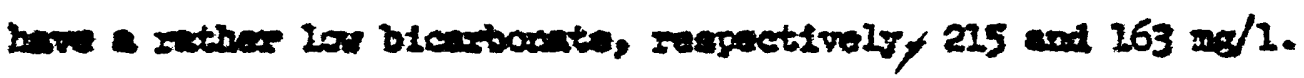

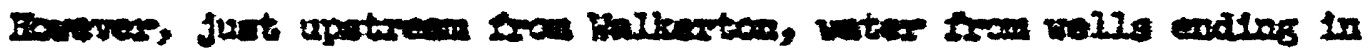

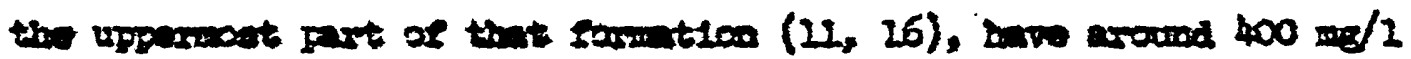

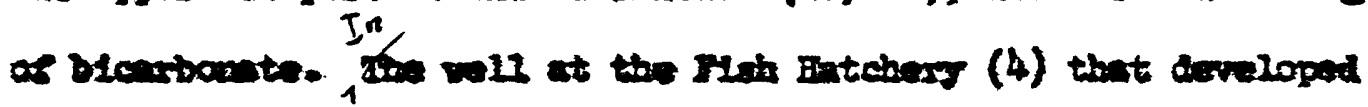

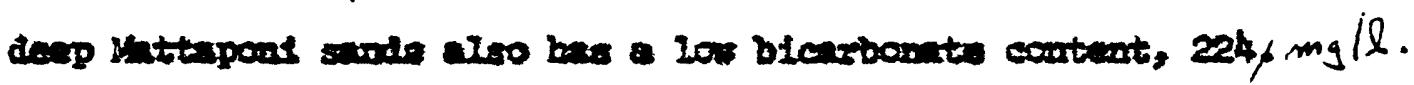

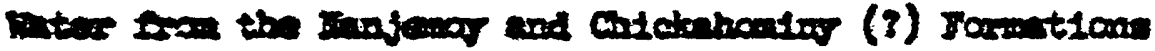

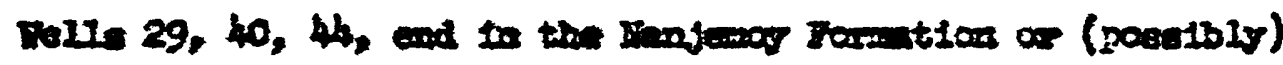

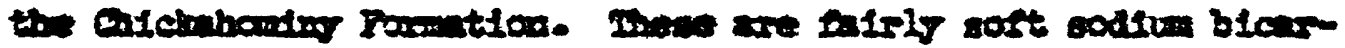

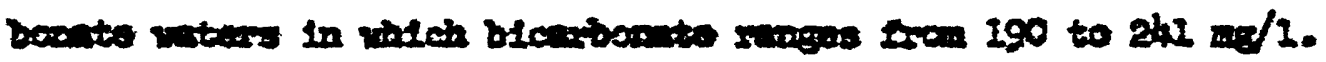

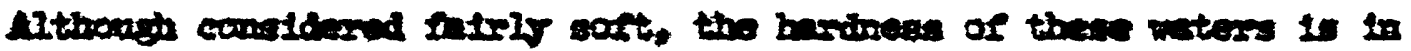

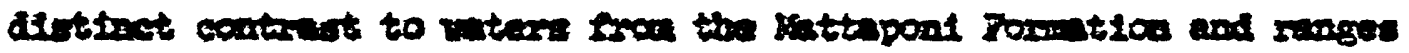

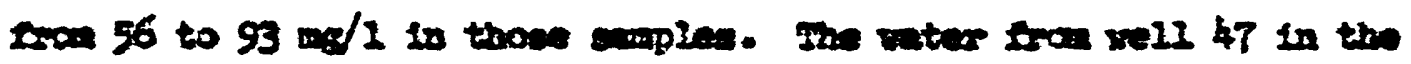

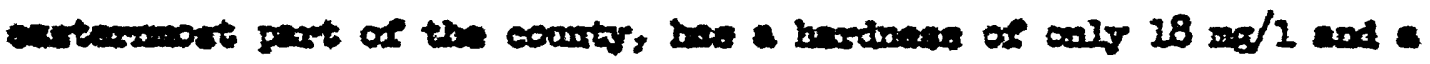

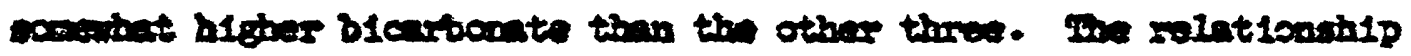

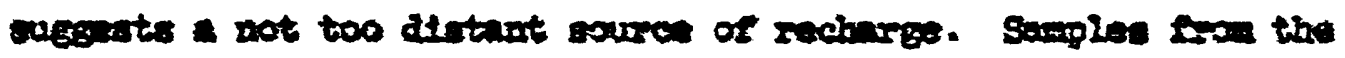

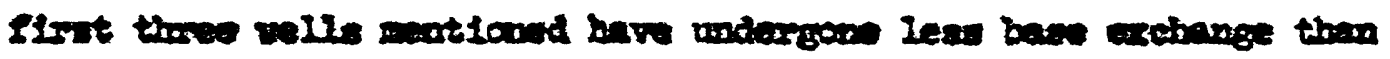

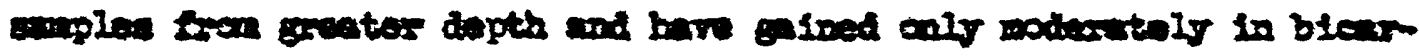

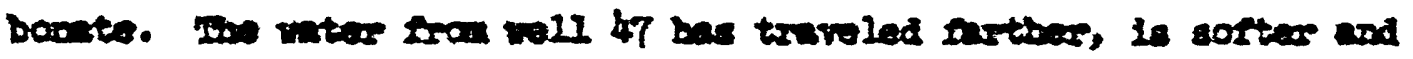

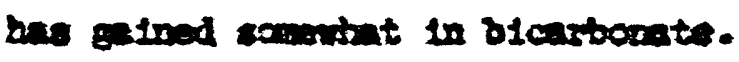




\section{Diter Iran Pleletocen Depoutto}

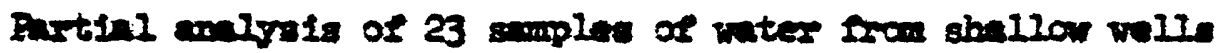

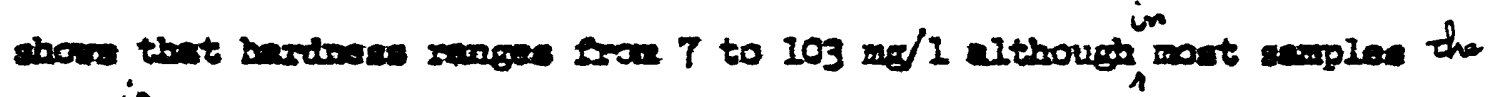

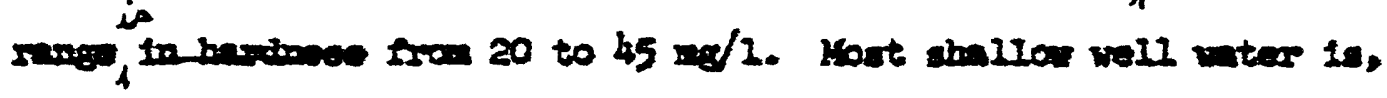

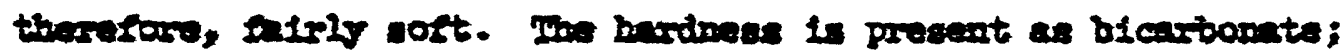

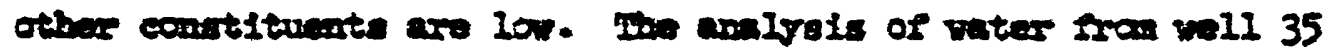
Is trictiol.

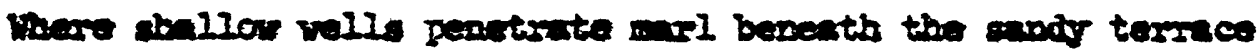

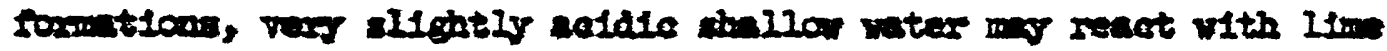
in the Inorl and becane tal-ir havd. 
Table 12 .-Log of WeIIs in King and Queen county, Va.

Well 3. Cirtilan Consenvation Corps. St. Stephon Crureh

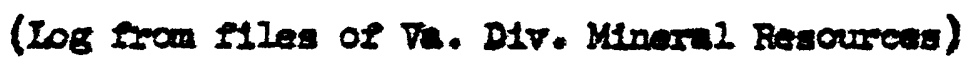

$$
\text { Alt1tude } \frac{192-(1)}{170} \text { foot }
$$

Fot deseribed

Thtaknone

(ract)

Dopth

65

65

Chaseparica Group (Mtocano)

$$
\text { vari, blue }
$$

230

Ranjemas Poration (Focens)

Rook

20

240

Merl, sou fine Band

15

255

Ims 1, blus

15

270

Boek

5

275

Undisforroutintad (roome to Fuleocene)

Nol, Blus

67

342

Enol. papper and olt

6

348

Rock, abelly, not bard

3

352

8und, bleck, and rook strata

10

361 


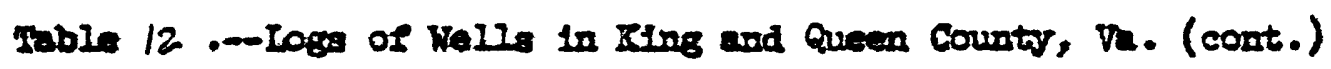
Woll 4, Pish Butchery, storensilile

Altitude 70 feet

Hateinear

(twot)
Dapth

(2006)

Columbis Group (Pletirtocene)

subsoll

Cosanpeake Croup (M10cena)

mor, blue

103

120

CIN, Dron

20

140

rajemor rosmation (roceno)

Band, white

2

242

gtow strate

33

275

sund, black

5

280

$\operatorname{sen} \sin$

2

182

Civ, blue

13

195

Aquin (I) Joumation (Euleocans)

stome

2

197

C19, blue

13

210

atud, biack

20

230.

cing, blue

35

265

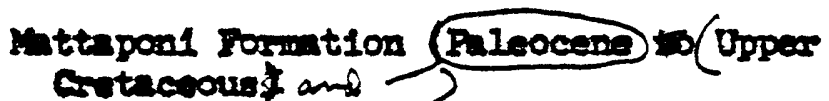

car, rad

5

275

ons, blue

15

290

cies, bard, green

5

295

clo, gras, glauconitic

40

335

stome, abelly

3

338 
Table 12.

weil 4

Suttapons pontion (cont'd.)

Clev, bluo, soft

sund, white, elayos

enes, red, sort

Clev, sottied

gund, whit to tout.

Daidecoesa

(50et)

Depth

(feet)

12

350

$14 \quad 364$

6370

60

430

35

465

175

170 
Table 12,- Iogs of Wells in King and Queen County (kaxt.)

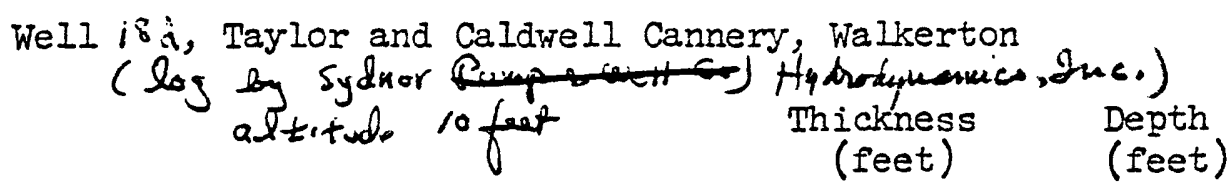

Columbia Group (Pleistocene)

Topsoil

4

4

Sand and gravel

14

18

Chesapeake Group (Miocene)

Clay, light brown

46

64

Nanjemoy Formation (Eocene)

Clay, shells, sandy

56

120

Clay, dark brown

20

140

Aquia (?) Formation (Paleocene)

Clay, dark gray

$52 \quad 292$

Mattaponi Formation (Paleocene (Upper Cretacisu ańl

Creverecosst

Sand, black, muddy

57

249

Clay, gray

43

292

Sand, white; water

3

295

Clay, mixed colors

47

342

Sand and gravel; water

4

346

Mud, sand, gravel, colored clay

10

356

Sand and gravel; water

361

Sand and gravel, clayey; water

5

377

Sand; water

16

390 
Table 12 .--Logs of wells in King and Gueen County, Va. (cont.) Well 3l, King and Queen Court House; King and Queen County School Board (Iog by W. S. Reynolds)

\section{Altitude, feet}

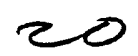

Columbia Groupd (Ple
chesapente

Columbia Groupd(Pleistocenet and Miocue)

Top soil, clay, and sand

50

50

Chesapeake Group (Miocene)

Clay, blue

60

110

Nanjemoy Formation (Eocene) and

Aquia (?) Formation (Paleocene)

Clay, brown

Sand and shells

Clay, hard

1

131

Clay, brown

12

- Clay, hard

$1 \quad 144$

Shells

6

150

Gray sand

5

155

clay, hard

Cretacesus ane

60

215

Mattaponi Formation ( $\mathrm{X}$ leocene)

Black sand (water) 
Table 12 .--Iogs of wells in King and queen County, Va. (cont.) Well 48, E. R. Rilee, Shackelfords Fork

(Log by Reynolds \& Norman)

- Altitude, 100 leet

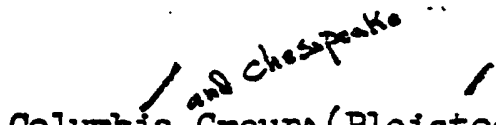

Columbia Groups (Pleistocene Eand Miecene)

Sand and shells

Chesapeake Group (Miocene)

Chickahoming Formation (Eocene)

Sand and stone, dirty

Sand and mud 1 Nanjemoy Formation (Eocene)

Clay, blue
Continued stone

Clay, blue and sand, glauconitic
Depth

( eet)

(leet)
17

$3 I$

14

2

13

245

258

275

306

320 


\begin{tabular}{|c|c|c|c|c|}
\hline$\ddot{\grave{g}}$ & & 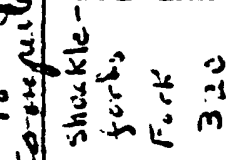 & $\stackrel{\vec{z}}{\vec{j}} \dot{m}=\vec{j}$ & $\frac{\dot{s}}{2} \stackrel{0}{\frac{\omega}{2}}$ \\
\hline$\xi$ & & 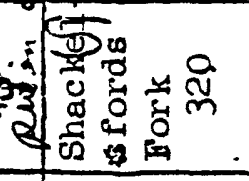 & 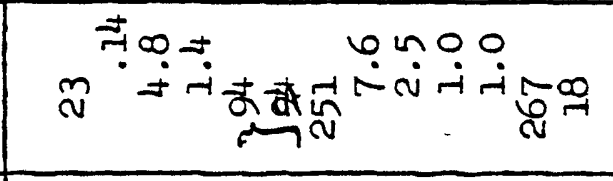 & 离章 \\
\hline 3 & $\exists$ & 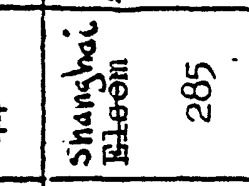 & 象品 & 危垈 \\
\hline${ }_{0}$ & $\cong$ & 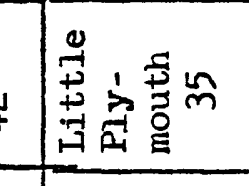 & 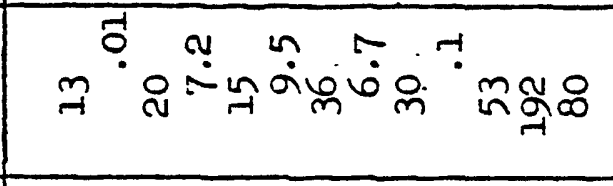 & $\ddot{c}_{4}^{2}$ \\
\hline $\begin{array}{ll}5 \\
\dot{5} \\
\dot{5} \\
\dot{4}\end{array}$ & 9 & 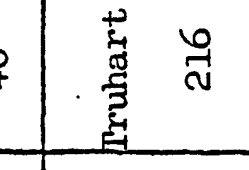 & 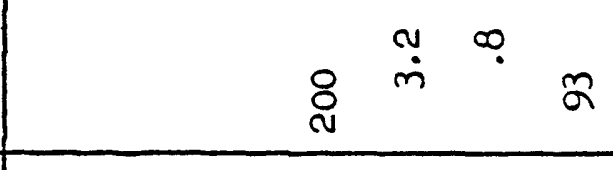 & 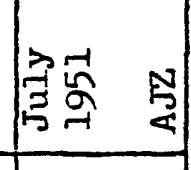 \\
\hline & ָิ & ง & $\stackrel{\text { nิsm }}{* 0}:$ a & 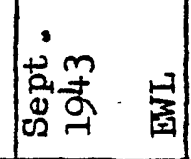 \\
\hline $\begin{array}{l}\Phi \\
\vdots \\
\vdots\end{array}$ & $\begin{array}{l}0 \\
3 \\
-7 \\
3 \\
3\end{array}$ & 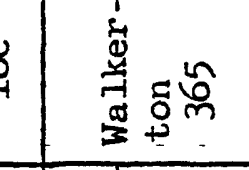 & 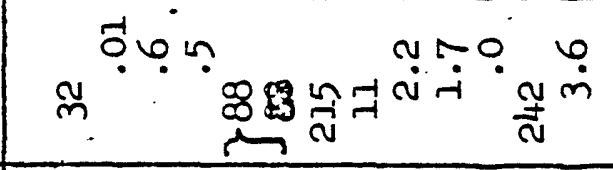 & 道䍃 \\
\hline is & ک & 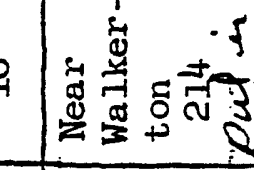 & 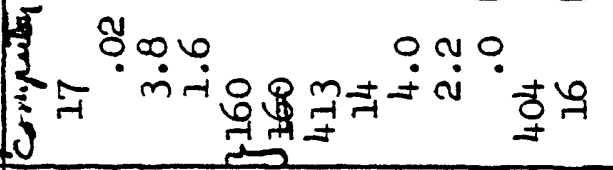 & 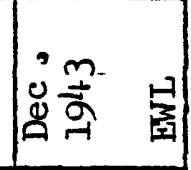 \\
\hline ن & 7 & 离 & $\prod_{\exists} \rightarrow a^{\infty}$ a & 遂典 \\
\hline 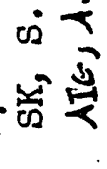 & n & 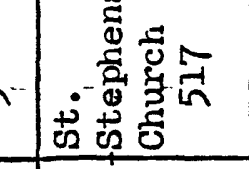 & $\stackrel{m}{\mathscr{q}} \stackrel{\mathscr{i}}{-}$ & 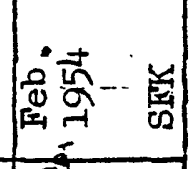 \\
\hline 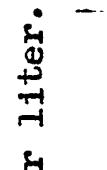 & * & . & 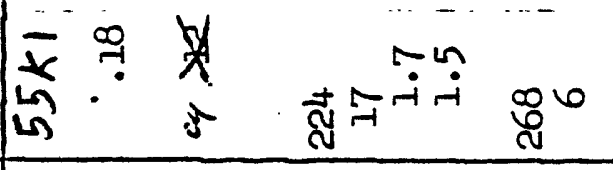 & 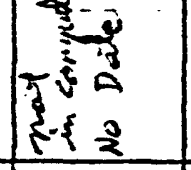 \\
\hline 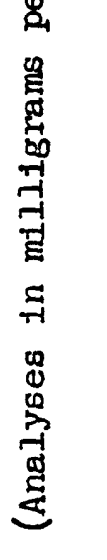 & & 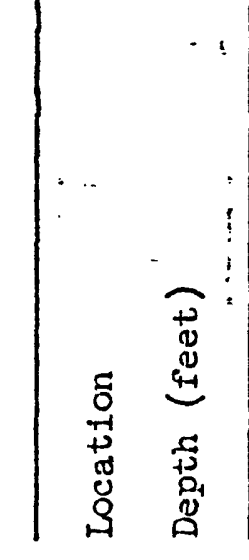 & 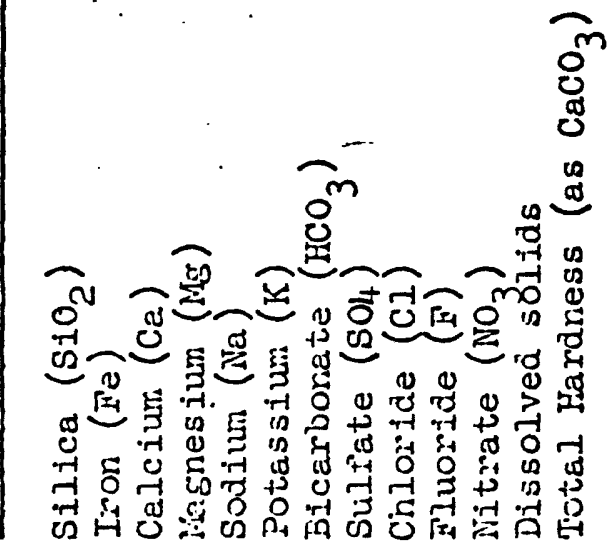 & 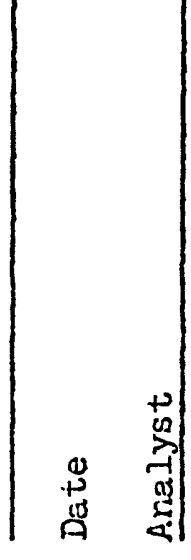 \\
\hline
\end{tabular}




\section{Gloucestor County}

Goucester County IIes between York RIver on the south and the Plandiatank on the north. The southearterp portion of the county bordisy on Mobjack Bay which opent directly Into Cherapeake Bay. The Ind aren is 225 square miles. The population in 1965 wes 13,082. Gloucenter has been the only hearlis populated locality but in recent years murked increnses in population beve taken place in the Gloucester Folnt area.

Although a Iusel county, only about 8 percent of the work force was employed in agriculture. The processing of rresh or frozen anfood is an important industry, as 18 lumberting. Fibergless bonts are whenctured at Gloucester and som bontbutiding is carsied on elcewhere.

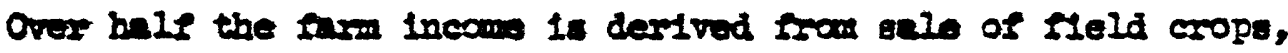
chlally roybeane and cons, a sifth rom sale of hogs. About 13 percent of the furm incem wes obtatned largely from bale of daffodils, both plents and bulbs. Poultry producta sccounted for about 10 precent of the exwin income and disy products about $2 \frac{1}{2}$ percent of the total.

In addition to the coumerelal actifitied mentioned, Gloucester

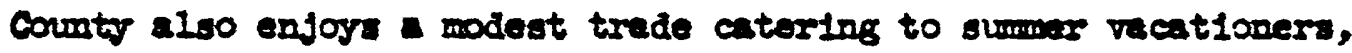
11sbarmen and tourlsts Flsiting polots of historleal interest.

0.8. Highuy 17 passes through the county and connects Gloucester with Newport News to the south Fis the George P. Coleman Manial Bridge to Yorktown and rith Fredericikburg to the nortbrest. 


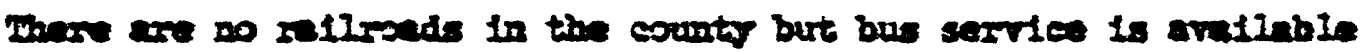

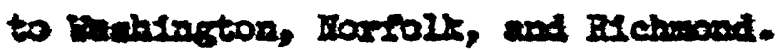

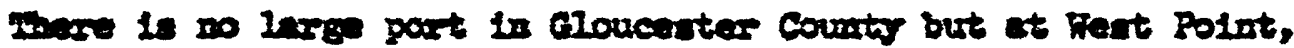

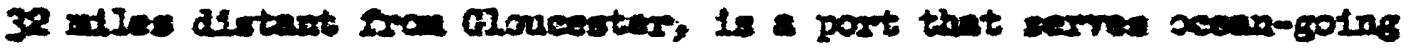
reanels as well as a sallrad. 
Geology

Bedrock

Bedrock was reached in a well at Mathews C. H. at 2,300 feet below sea level and at West Point at 1,257 feet below sea level. Hence, in western Gloucester County, bedrock may be about 1,600 leet below sea level and about 2,000 feet below in the eastern part of the county.

\section{Cretaceous System - Potomac Group}

The Potomac Group consists of alternating strata of clay and sand of Early Cretaceous age. These beds underlie Gloucester County but have not been reached by any wells in the county. As shown in section $B-B^{I}$, potome sediments might be reached at about 950 feet below sea level at Gloucester (Court House.

\section{Cretaceous to Tertiary Systems}

\section{Upper Cretaceous and Paleocene Series}

Mattaponi Formation: The Mattaponi Formation is of Late and

Cretaceous to Paleocene in age. It is ordinarily characterized by mottled clays in its lower portion and by rather highly glauconitic clays in its upper part.

The boundary between the underlying Potomac beds and the Mattaponi Formation is problematical in Gloucester County.

\section{3}




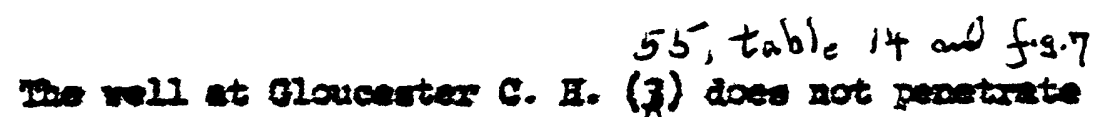

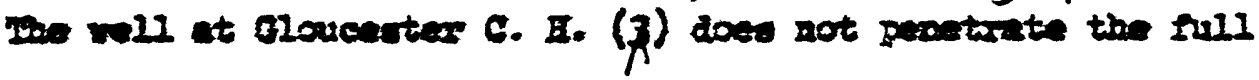
section of the knttapond Fosmation and in ary ereat, the bondary

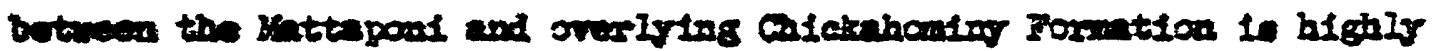

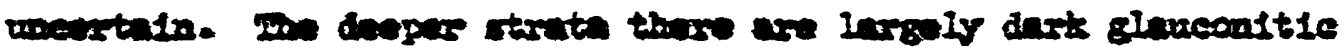

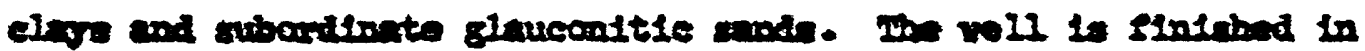

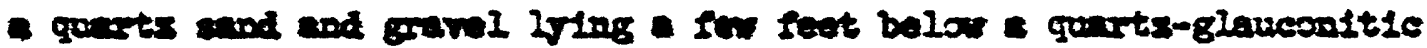
sod.

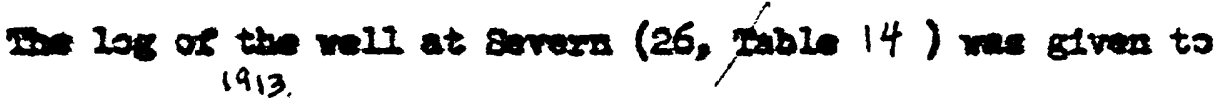

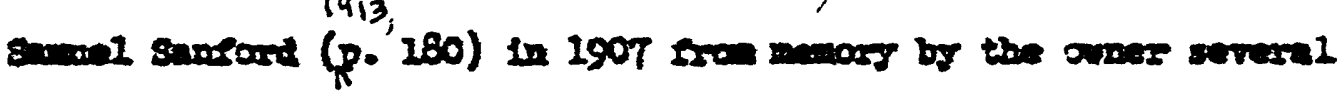
Jens after contarietion as that wil. Inte 108 is almont viluo-

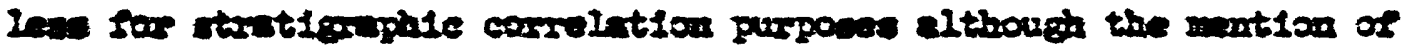

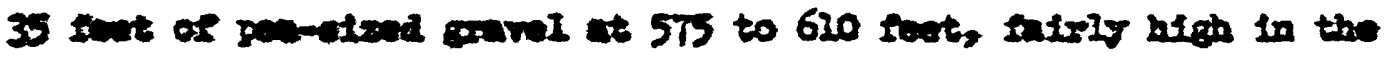

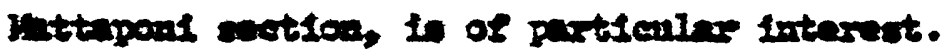

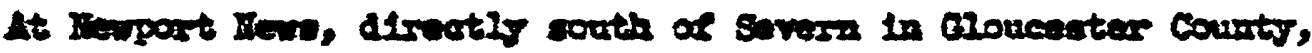

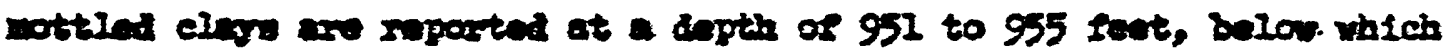

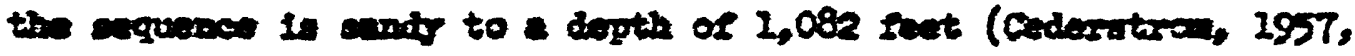

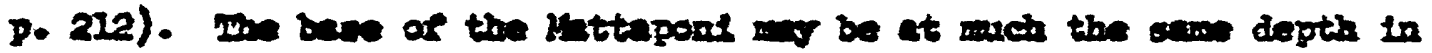

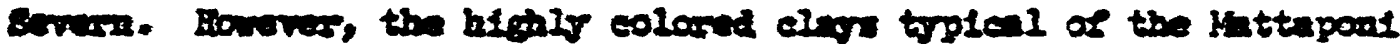
bow not been sepoxted in the sw Iog at band of deap will in

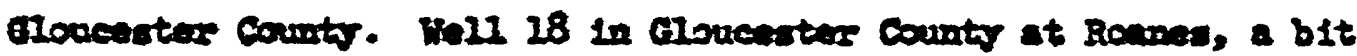
wert of semarn, reached the "prinespal aquifer" at 850 laet and wa

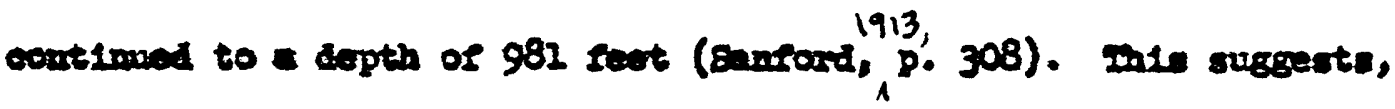

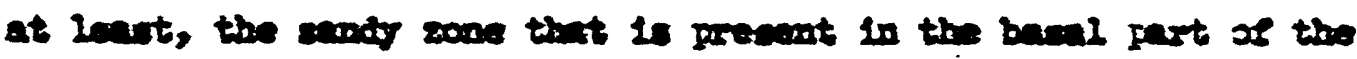
Hatepous at Boat Polnt. 


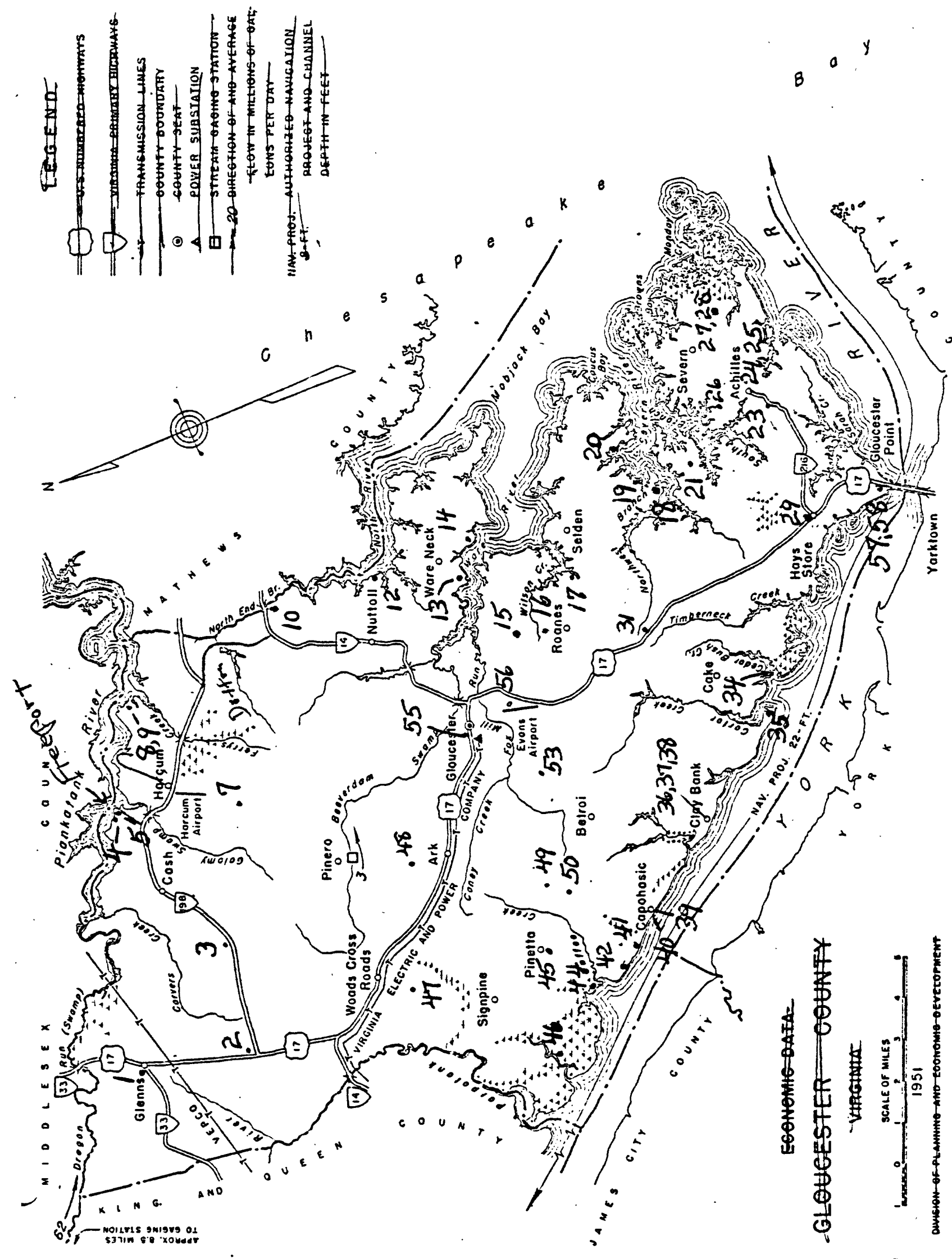




\section{Eocene Series}

Nanjemoy Formation: The Nanjemoy Formation of Iarly and Middle Eocene age is probably present in western Gloucester County but thins eastward and may be absent east of Capahosic. The Nanjemoy is made up of highly glauconitic clays and sands with occasional very thin limestone strata.

Chickahominy Formation: A few feet of fate Eocene sediments are present at West Point. The formation thickens eastward and probably make ${ }^{S}$ up most of the Eocene section in central and eastern Gloucester County. Reasoning from data available on the YorkJames Peninsula to the south, it seems likely that the Chickahominy Formation is 100 to 120 feet thick in central and eastern Gloucester County. The well (42) at Capahosic penetrates 60 feet of preMiocene sediments. These are all assigned to the Chickahominy. They consist of alternating clays and sands, in part glauconitic. A. "hard bed of shells" near the base of the section may be coquina, ordinarily termed "limestone" in other logs. The yellow clay reported is unusual. One of the other rare reports of yellow clay is at Newport News where "sand and yellow mud" is logged at 450 to 500 feet and "yellow clay" at 500 to 525 feet (Cederstrom, 1957, p. 229). There the yellow sediments occur in the lower part of the Eocene section and in the immediately underlying Mattaponi(?) Formation.

Wells 4 and 5 at Freeport on the Piankatank may also develop water from the Chickahominy Formation. 
The contact between the Mlocene forwations and the underlytag Irocens forwation would appens to be at 387 feet (317 feet below an lervi) at Gloucester C. H., but grojection of the fubable contact

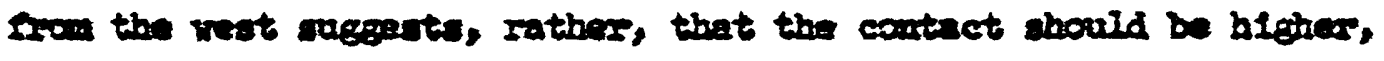

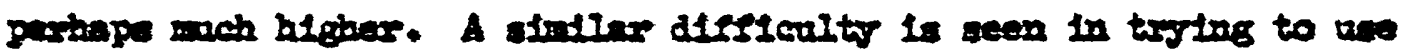
the severn 108 for statigrephic correlation. Hence, it seam

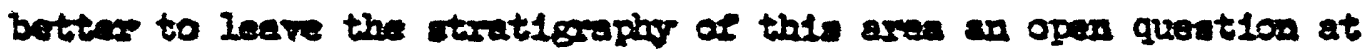
thet tins. 


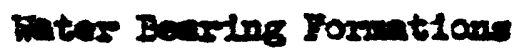

aretaceous sroter

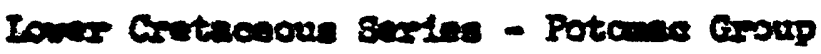

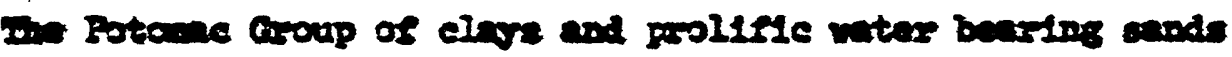

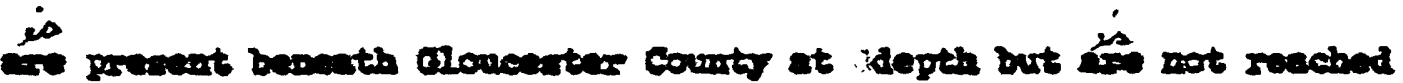

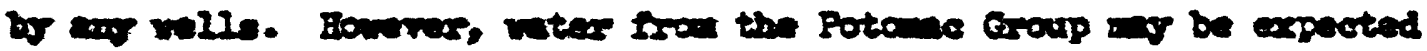

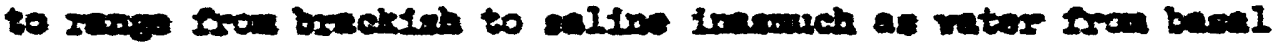

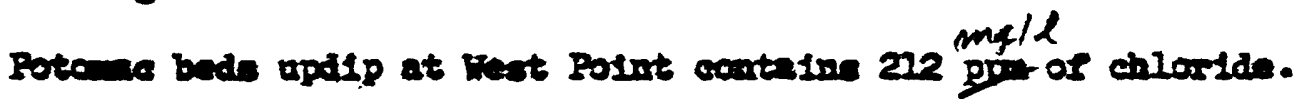

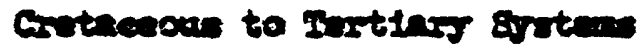

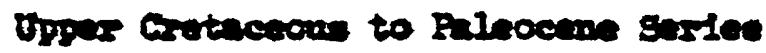

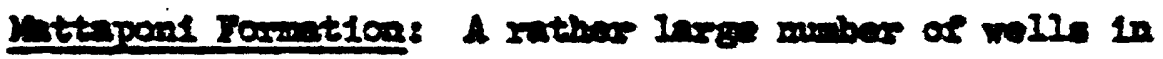

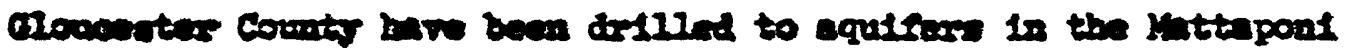

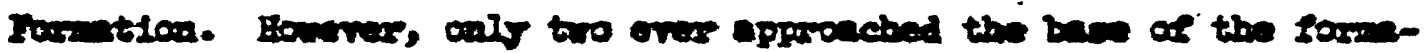

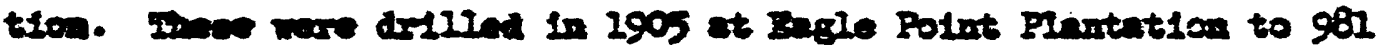
(or 900) and 1,004 surt, swopentively (sanford, 1913, p. 179, 308)

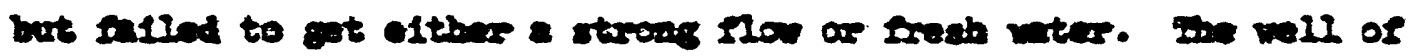

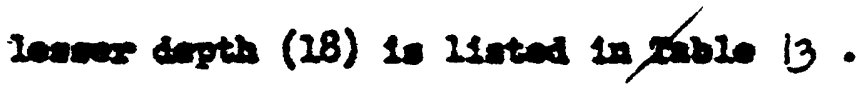

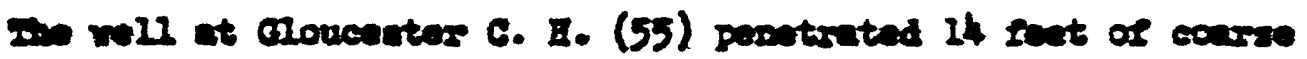
and and govel at 730 sect betom ace level, well dam in the

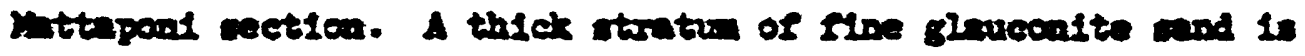

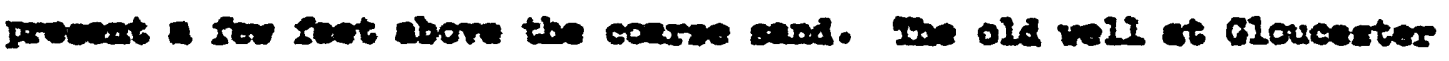

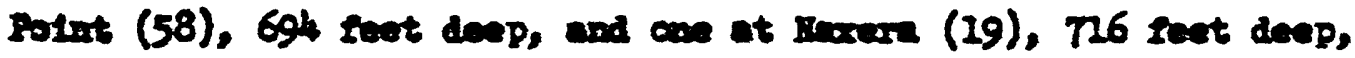
and in rach the now horlson. 
A scumbat persintert stration eppeare to be present a l1ttle hfthere in the section. It was reached in well 26 at Sorves at a Carter Creek

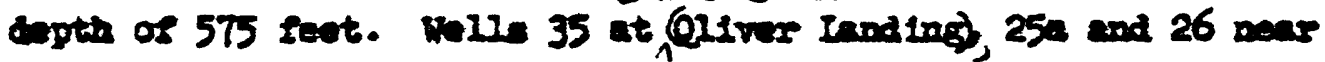

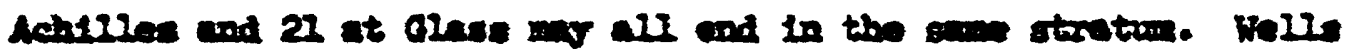

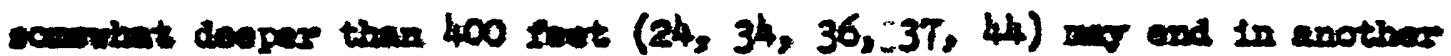
watembearling and high in the Muttapont sequence.

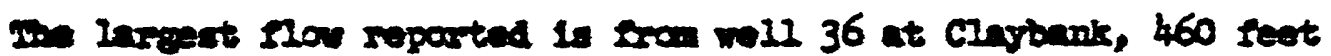
deop, which had a now of 35 gre in 1918. Well 19 at Roenos, 76 suat deap had a now of 52 apd in 1906 and 10 gron in 1941.

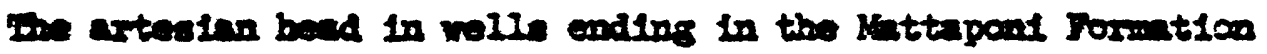

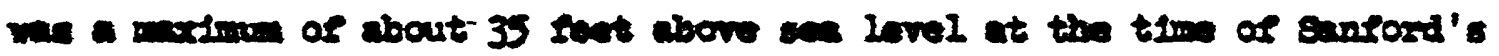
cunves is I906. In I945 veter would Fise to onls about 3 feet above

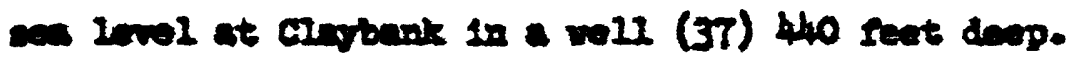

An infersed above, no 2 wree grantitied of water have been

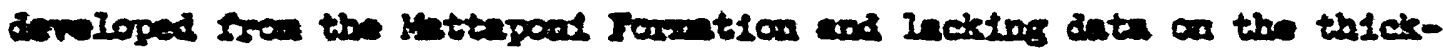

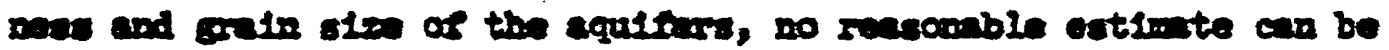
ade of bow such weter infot be developed in a single well arvibere.

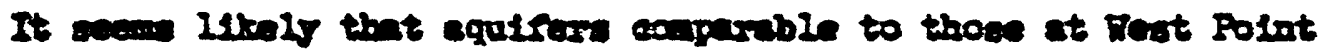
whould be present in the wertern part of the counts and wase such

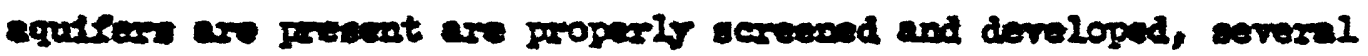

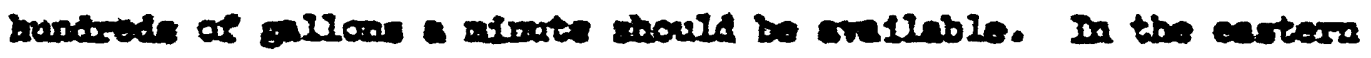

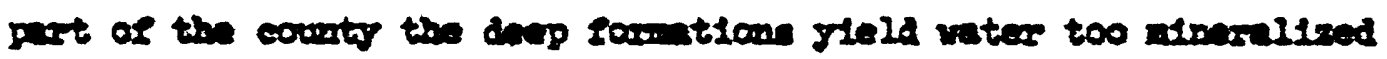
for nowt unes. 


\section{Hocere sates}

\section{Owing}

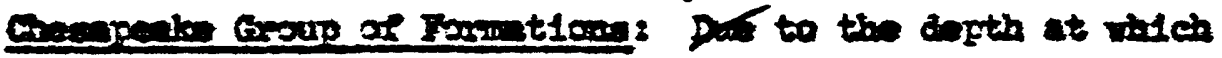

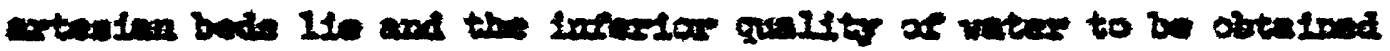

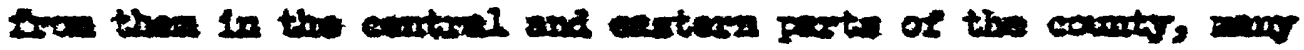

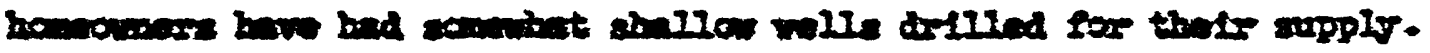

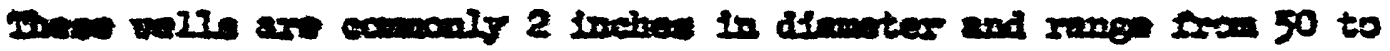

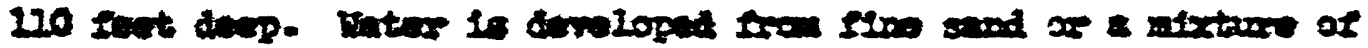

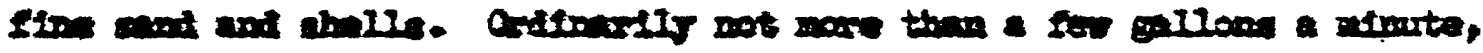

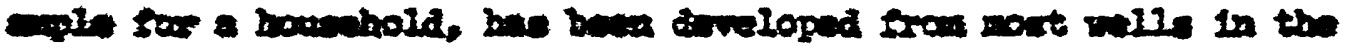

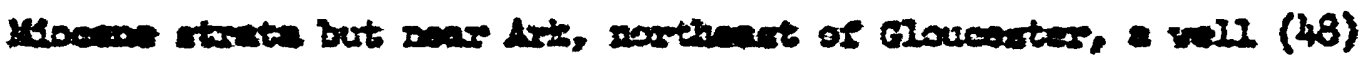

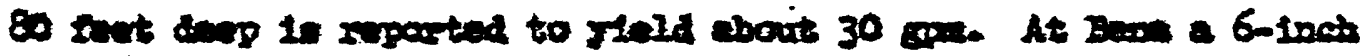
wi23)

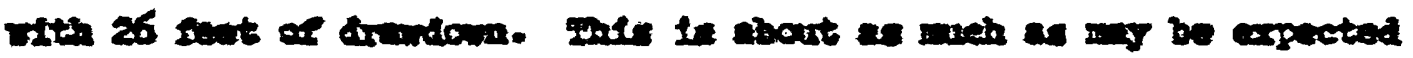

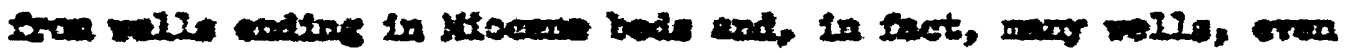

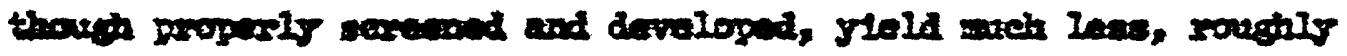
$\operatorname{sen} 3$ to $10 \mathrm{mon}$

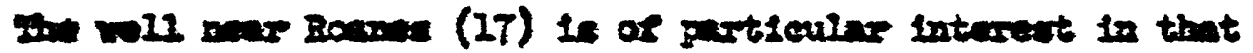

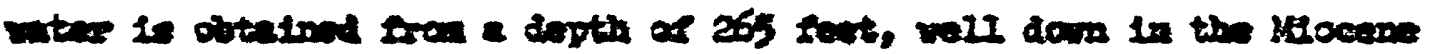

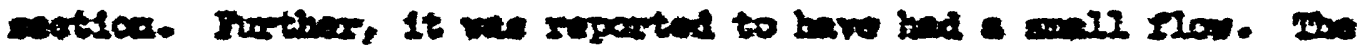

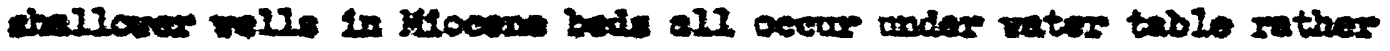
thin ortenim condition.

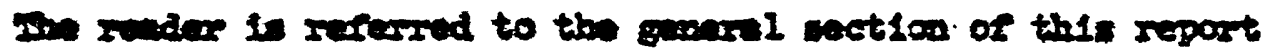

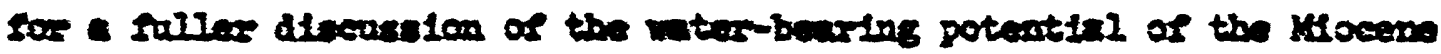
soriatione. 


$$
\text { Quaternary System }
$$

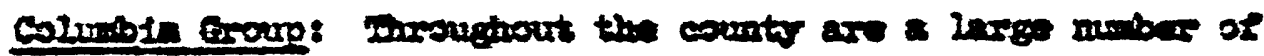

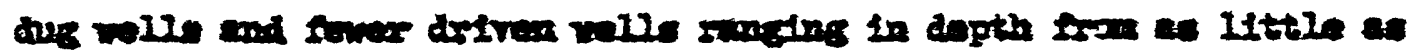
10 to about 35 enct.

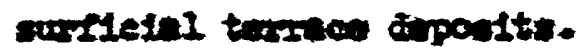

$$
\text { (57) So.nt }
$$

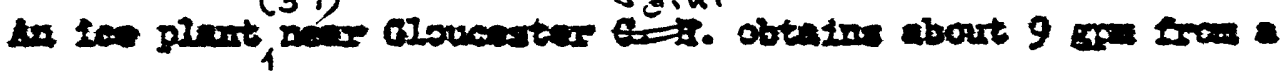

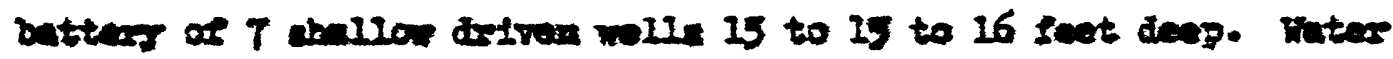

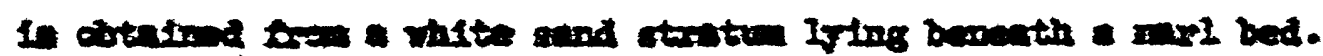


Sonisto of Batex

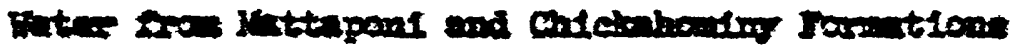

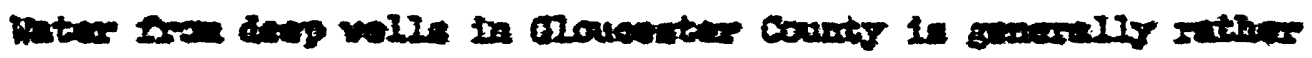

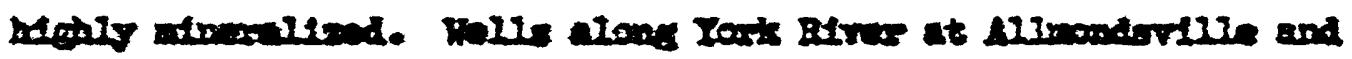

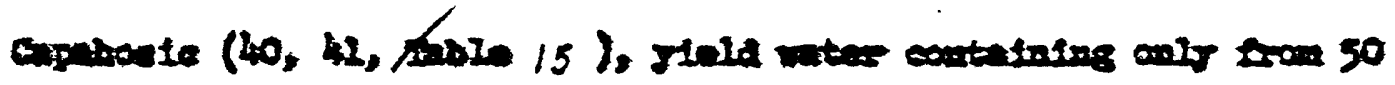

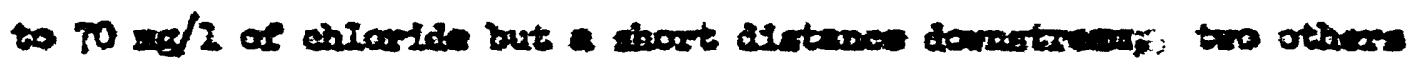

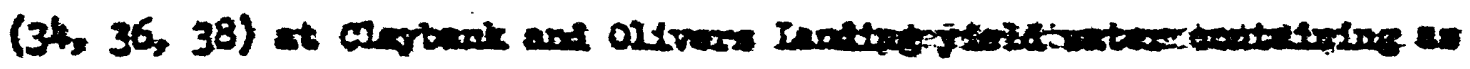

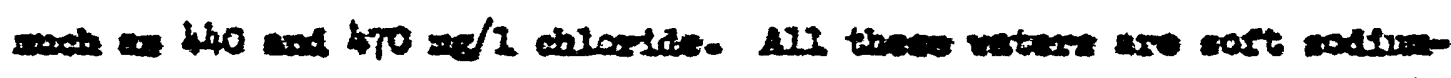

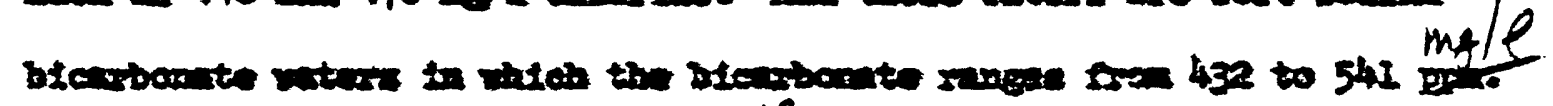
sulente is meris low, 12 to $58 \mathrm{mg} / \mathrm{l}$

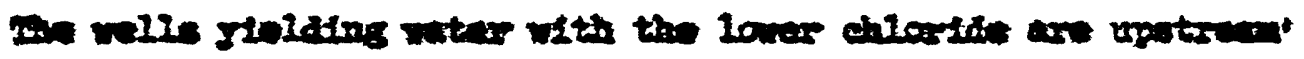

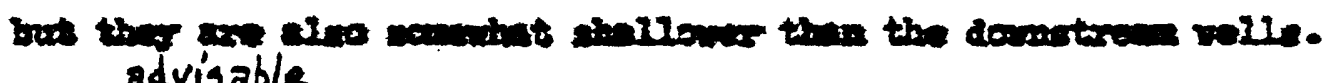

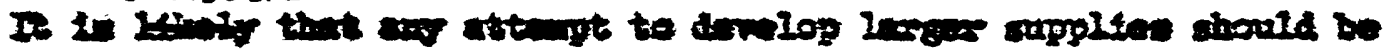

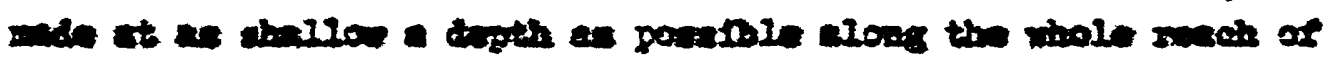

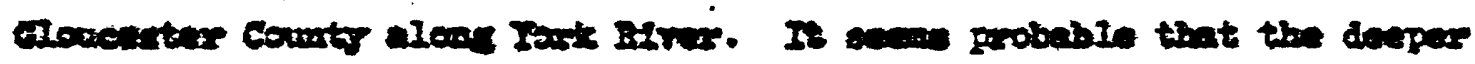

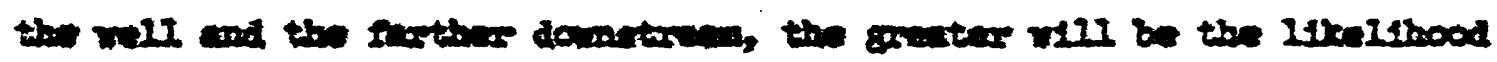

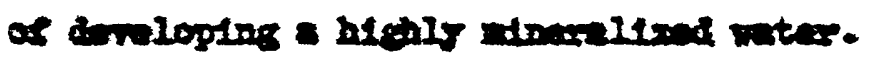


At Ireeport on the Planiontanis the reter fron the 330-foot rell (4) Io of much the name chrncter as those along upper Iort R1vor. ciloride is the Hooport well wates is ools around $30 \mathrm{mg} / 1$ although

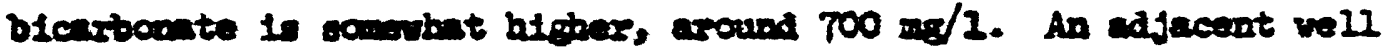
(5) rielde water thet is elmont identical in chemical character and If thought to be of abourt the ane depth although 14 wa reported to be med deeper. It wy be noted that directir werose the Planicatank, - 500 (I) foot well at Doodntock Farm ylelds water contalning $294 \mathrm{mg} / \mathrm{I}$ of chloride (42, table 9 and 18. 5 ).

ithe manlespal well (5S) at Gloucenter C. B. extende to 740 feet below see level and tape a deaper aquirer then the will montioned

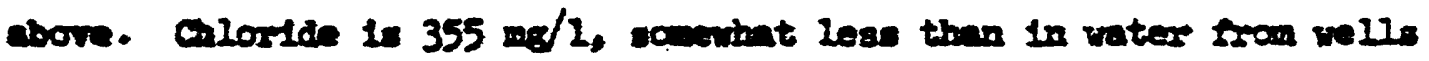

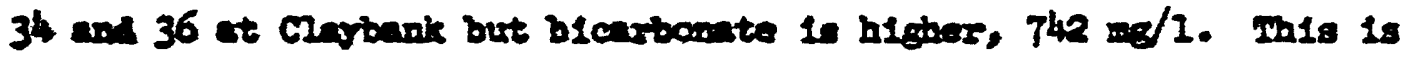

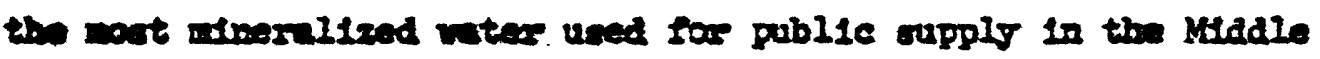
Puninguls and probubl' in ell of Mdewater Virginte.

De old $694-$ foot well (58) at Gloucostar Polnt, glelds rater is which chlorid is about the concentration as at Clavbenk, about $430 \mathrm{md} / \mathrm{l}$, but blearbonte is algher, around $800 \mathrm{me} / \mathrm{l}$. At

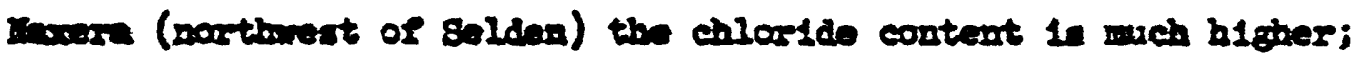
$1,700 \mathrm{ag} / \mathrm{l}$ in wher from a n6-20ot well (19) and $1,090 \mathrm{mg} / 1$

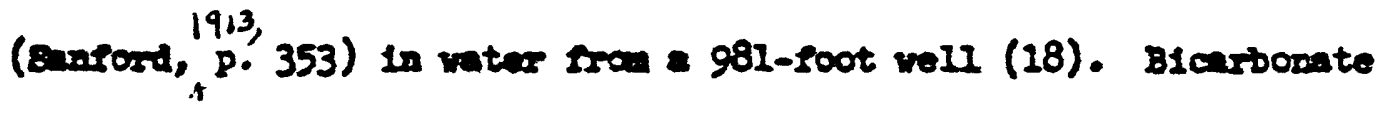

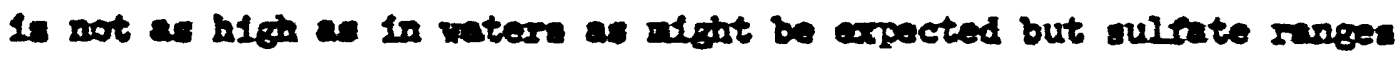
up to 155 ppe. Inis ergegests that the high blearbonto ground vater ha been "a1luted" vith a l1ttle of the sea vater with which the wodsmute vers once saturated. 


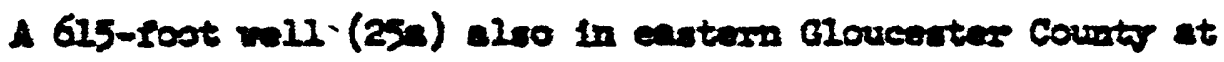

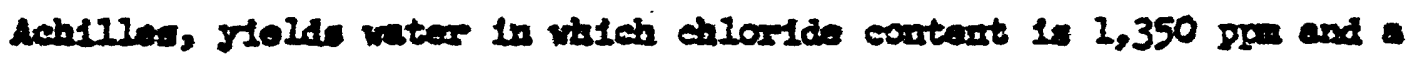
450-poot well (24) there (Surrond, p. 306) Jleldod water with

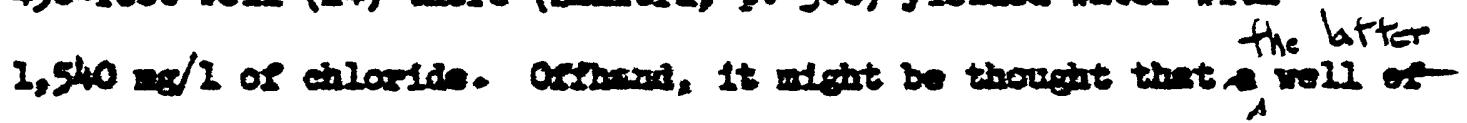

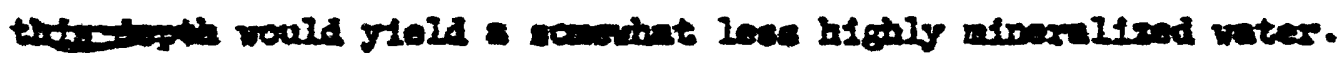
we hlopert enloride contert found in devp well water in the county, 2,500 ad/, is sron a 610-toot vall (26) at sevard (sansond, p. 351). It Is a pard water, as contarasted vith othes deep wall vintem alreadr

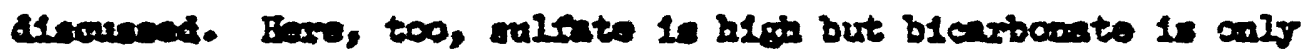
adoutely high. 
Soft woters of moderntely low chlorlde and high blearbonte

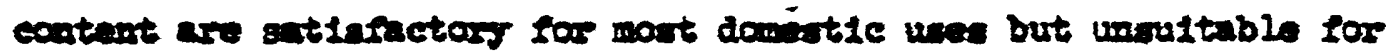
sow industailal usea, particularis bolies feed. High chloride

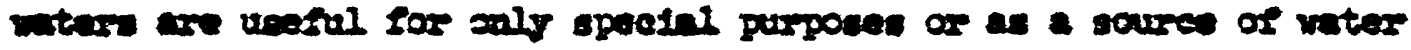

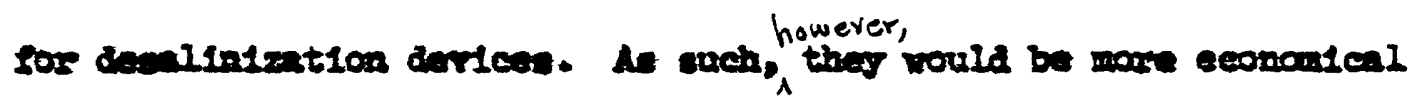

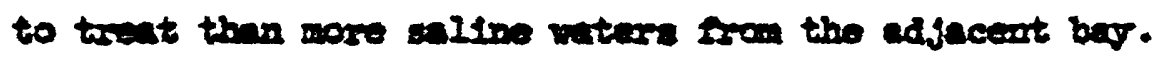

Althougt the Iow ehloride nuters are excellent for doneatic

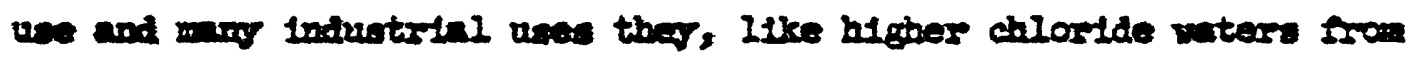
deeper vells, we undestrable for irsigntion une an account of thet Low colctur and hifh sodiun cootent.

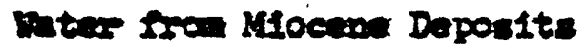

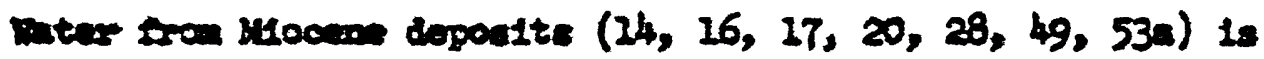

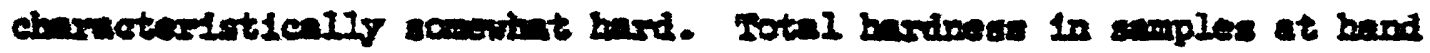

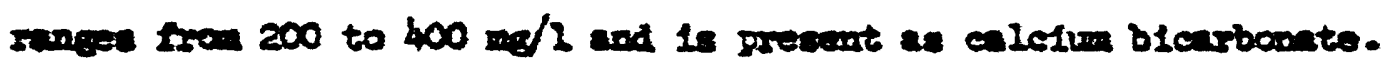

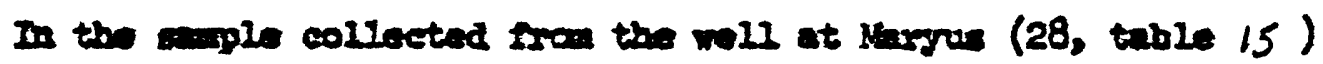

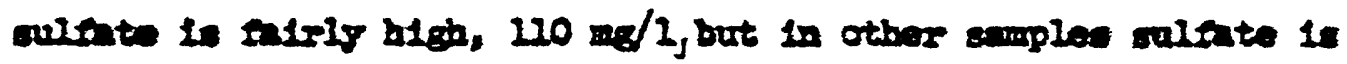

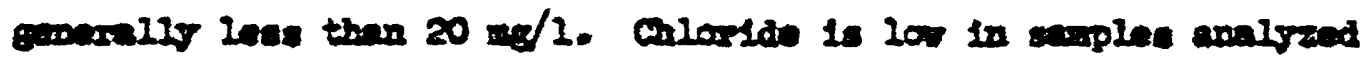

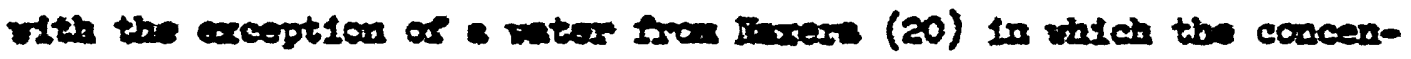

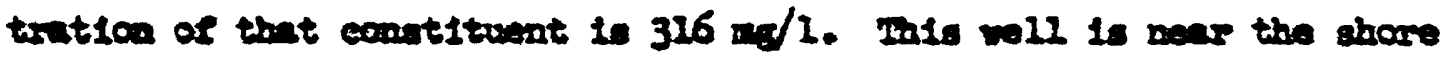
od mo be contentented bo bes vatare. 
Becalse the concentiation of clelum is high reletive to

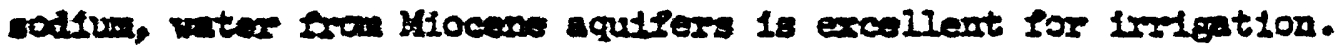
you problen in uning such vater for that purpose is the development af suffictent quantities whthop than the quality of the water itself.

\section{Detes from Plelstocen Deposits}

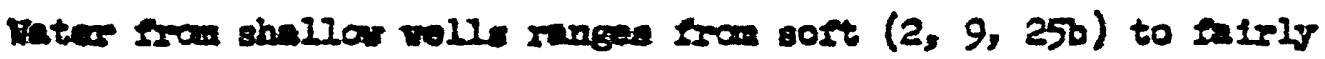
bard (2T, 5T), the burdseds being prosent largely as calction blcarboute. The chloride content sunger 20 to 60 pgo in most samples. In mones as total minesalizetion is low in mogt instances, woat

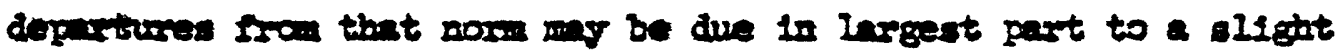

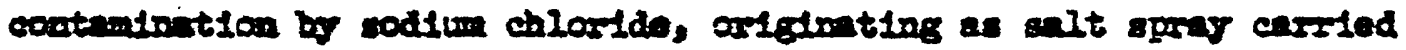
ores the Innd.

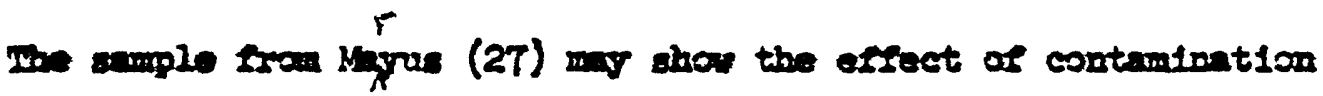

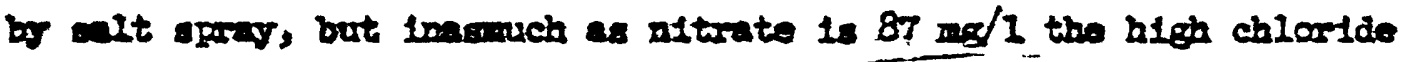
coutent my perhaps be dus to coutandration by organic materfal Inther than by alt apray.

Hort veters from shillar wells axe susceptible to contaniontion by argante materisl and in the other three samples takon, altrate magee eroe 20 to $28 \mathrm{mg} / \mathrm{l}$. 
Inasmuch as the artesian water at Gloucester C4 and Gloucester Point is relatively high in chloride, it.would be desirable to point out some method of improving the quality of that water if it were possible. The only solution that suggests itself, aside from bringing in water some distance by trunkline from the eagt, is blending with properly protected shallow water supplies, injection of shallow water into deep wells, or both.

Shallow well water can be made available only in modest quantity in the area of Gloucester C.H. a bank of shallow wells in the Gloucester C.H. - Ark area might produce enough water to be worth pumping to Gloucester C.H. and blending with the water from the present city supply. Utilizing methods outlined in the general part of this report and recharging the deep formation by small diameter wells in a shallow well field on the high ground northwest of the city might be done but the principal gain would be in a slightly higher pressure head. Recharged water would move so slowly in the artesian beds from the recharge point to the city well under the existing low hydraulic gradient, that it would probably be many years before any of that water had a dilution effect on the formational water now drawn upon. The better use of any shallow ground water that might be developed would be, as stated above, to blend it. with the presently used supply. Were larger quantities of shallow water available it might be worthwhile to consider recharging the somewhat brackish water formation through an injection well in the immediate vicinity of the supply well. 
The subject of artificial recharge of brackish water wells is discussed in some detail in the chapter on Mathews County.

The situation at Gloucester Point is much the same as at

Gloucester C.H. Deep wells there yield a high chloride water and shallow water supplies are available in reasonable quantity only at some distance from the point of greatest demand. 


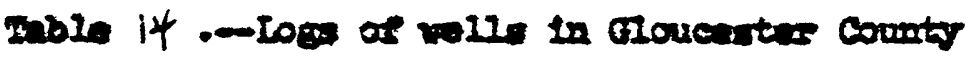

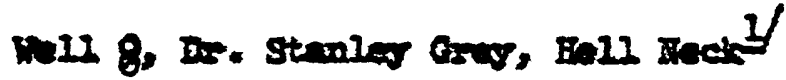

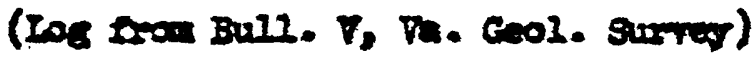

Alt1tuade 20 suet

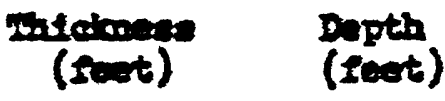

Columbir arourg (Pledrtocene)

Endis vatare

15

arv

15

30

$\sin$

4

34

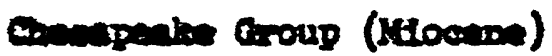

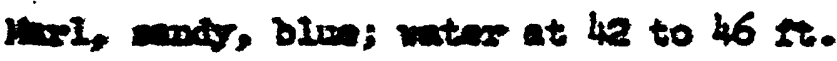

201

235

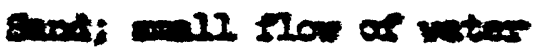

2

237

onisezerentinted

$\min$

248

385

Hock, wort; to veter at 415 2t.

30

425

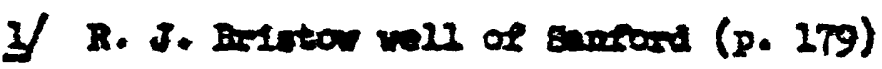

$2 r$ 
Tuble 14 . - Io of wells in Gloucester County, Pirginie (Cout.)

Diell 23, Bators Bat, Ban

( $\log$ by Sydxor Afydrodynemies, I ke.)

Thidemese

(reet)

Degth

It 1 tude 10 seet

Colmola Group (Plaistocone)

Toperoll

1

1

Civ, rellow

3

4

sund, sellor, 190

12

16

sand and eloy

3

19

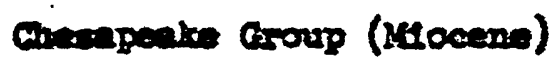

Dry, blow, shells

9

28

lan, blese and abelle

15

43

Co. blus

11

54

Sondis, hard

7

61

sund, undos, and shelie

31

92

Clar, blow

13

105 
Iable if .-Fogs of walls in Gloveseter Counts, Virginite (cont.)

Fall 26, J. M. shrakselford, Severn

( $\log$ from Bull. I, Va. Geol. Suruey)
Altituder 8 Leat

Th1choses Depth

(feet) (leet)

Columbin Group (Pleistocene)

Clor

11

sand, whtto

67

sand, yellow to red; water

I 8

Chesapenke croup (MLoceno)

Murl, shello

$10 \quad 18$

send, gays vater

624

Inxi, siand

46

70

Ondifforentinted

Morl, blua, a ser shella

355

425

Sund, bleck; vator under Lowhead

$15 \quad 450$

Mud, darst or green cant

135

575

sund, black, in hard levers; vater under low beed

55

610

Cravel, pebbles the alse of vheat crains; vater under atrong hend

$?$

$?$ 
rable if .-Fiogs of wells in Gloucester County, Virginis (cont.)

WelI 42, Hrs. M. D. Junnelly, Capahosie

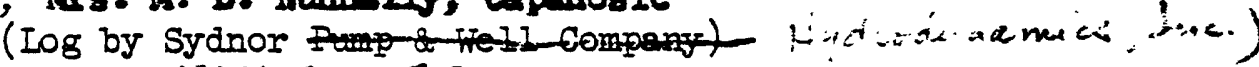

Altitade 25 feet

$\begin{array}{ll}\text { Deimegs } & \text { Depth } \\ \text { (feet) } & \text { (feet) }\end{array}$

Columbia Group (Plewfocene)

Cins, sellow

8

8

Mar, yellor sends and vitte sand $7 \quad 15$

gund and orvel, consese

10

25

Sust, elose viste

Chesapeathe Group (Mrocene)

27

$\underline{52}$

sum, biecte and pard, for sholls

51

103

Crop, dexis blue

35

238

cror, blue

38

176

san, fine wite, tew shellu and beome sock

180

Qras, dark

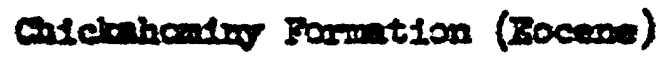

sand, sine

224

Sand, modiun coarse

10

234

Sund and sbello

Nad, yolzor

2

239

Sand, mados and abella

Mud, ons

4

250

hid, orey and tipo black sand

4

254

Bbel1s, ,hard bed

13

267

Glor, black sand and flne beach sand

$8 \quad 275$


Fable if - - Ioge of welle in Gloucester County, Virginie (cont.) neil 46, B. C. Coleman, 318mptoe

11titude 3 suat

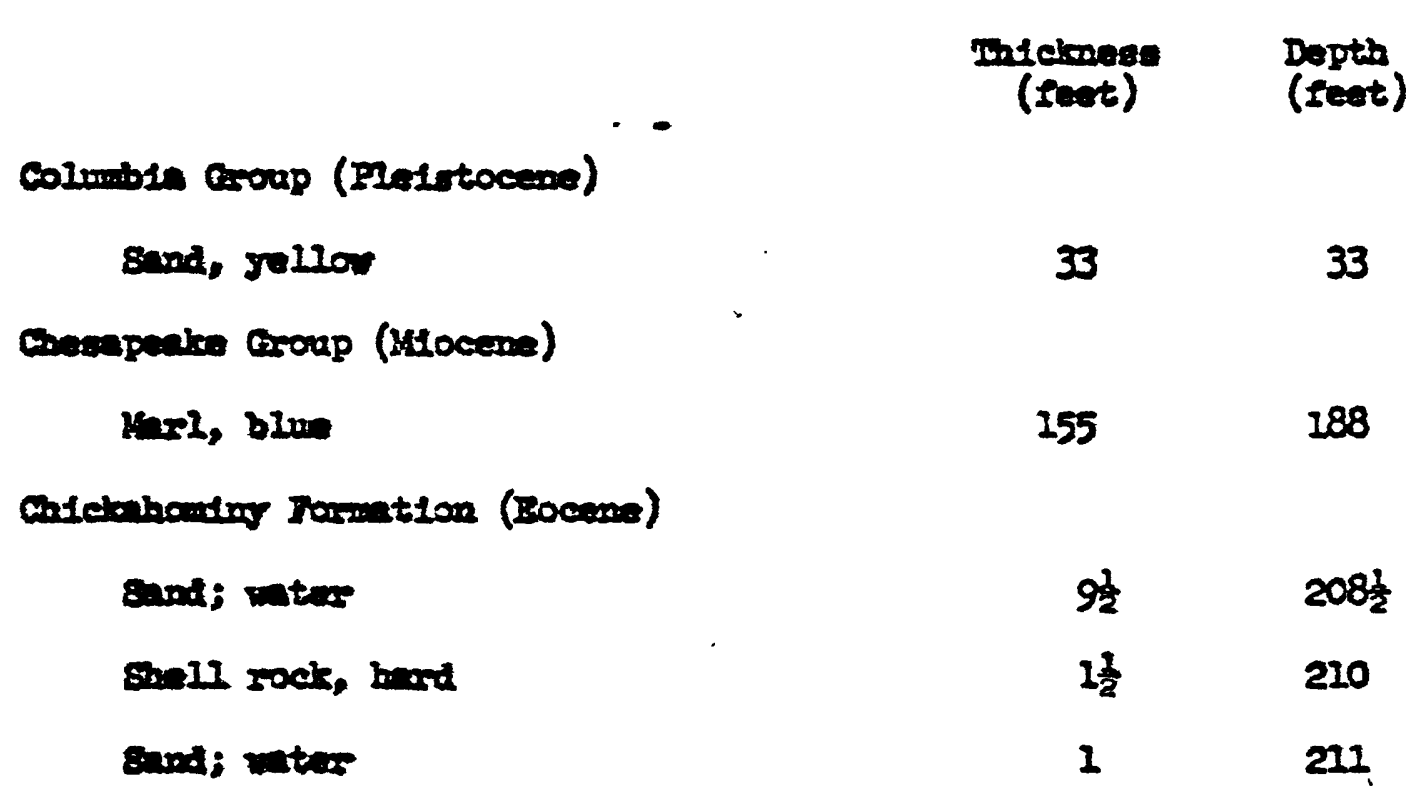




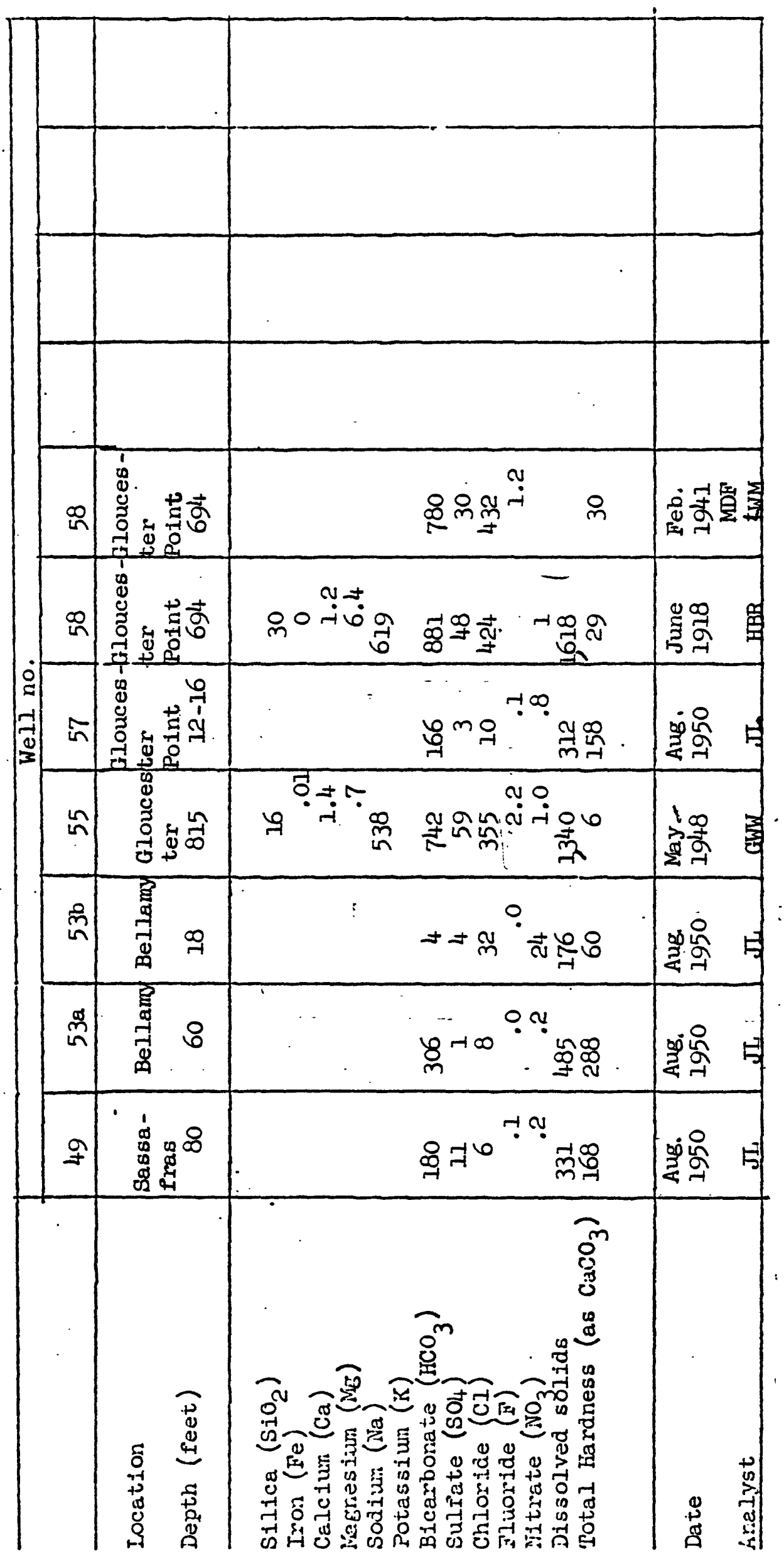

209 


\section{Matberv County}

\section{Intanduretion}

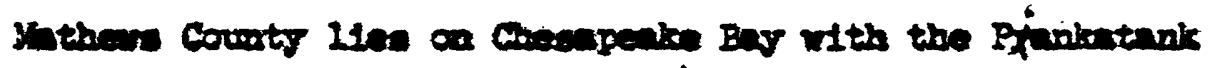
and.

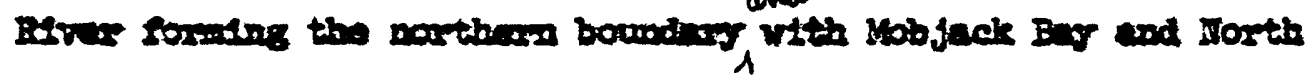

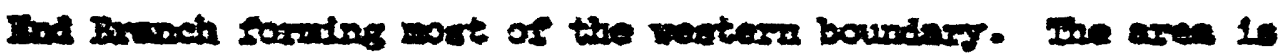

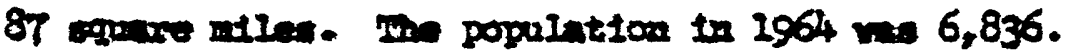

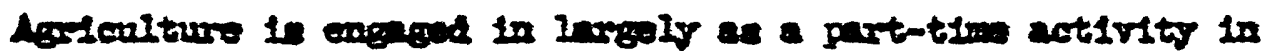

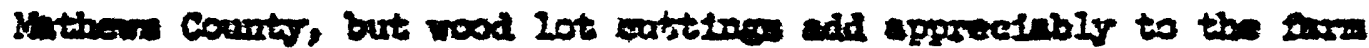

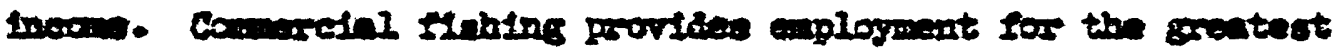

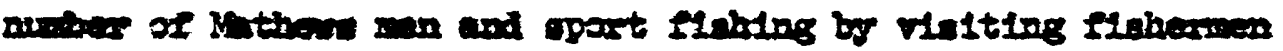

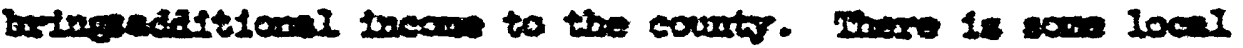

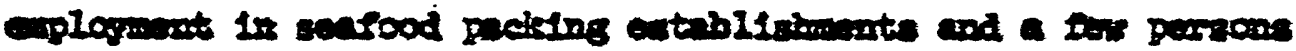
Itind wark in andis. 


\section{Geology}

Constderetion of the gealogy of Hathere county hinges upon the 109 of the deep wall at vathowa Coure Bousi $(39$, table 17 and 11g. 8). That will pantetrated the complete section of constal plato sadionts and anterred bodrock at a dopth of 2,307 foot. this is the only record showing the thickeness and charmeter of

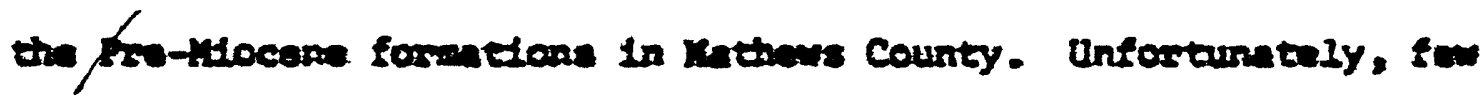
saplea ave aveliable and the description of the formations is not anffictentiy detailed to define the lfatts of the verious gealogle unstes.

Sedinents of the Potome Group of Enily Cretaceous age are peactratad in this will, extending perhape from a depth of gerhaps feet to basament rock at 2,307 feet. The boundary is dram an the basts 


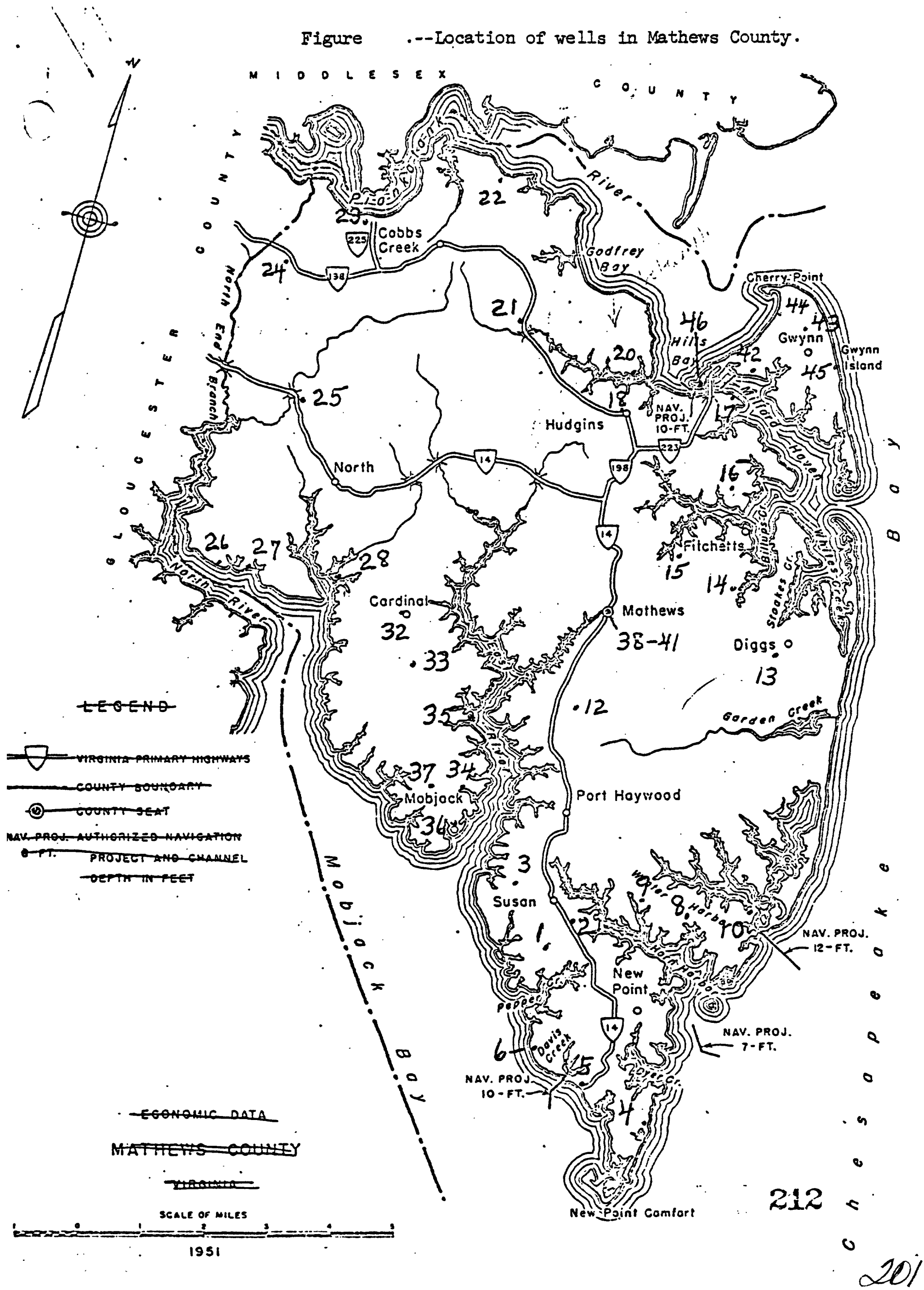


of a poutble correlation brarees baeal Nattapons ande at peot Bolnt and a thich sand at yathere. The seotion is ande up of altar-

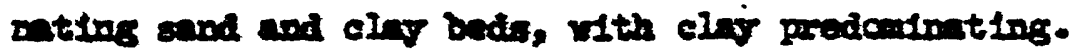

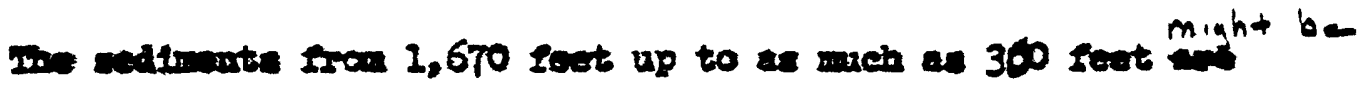

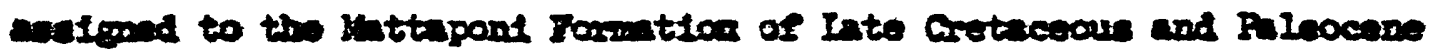

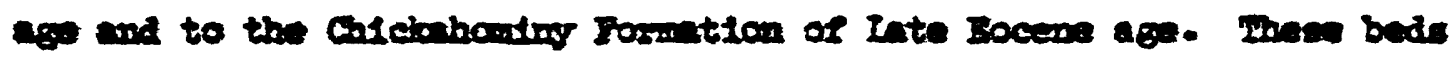

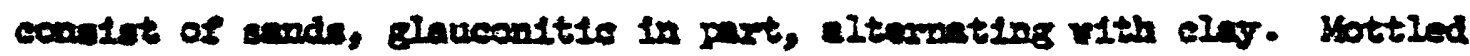

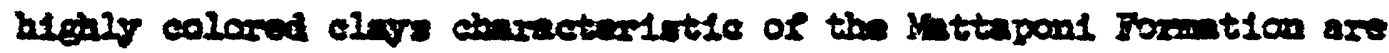

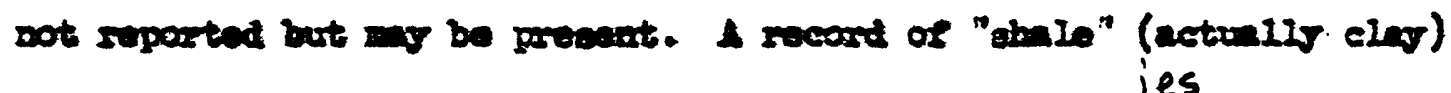

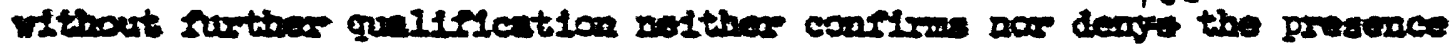

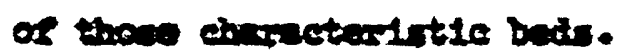

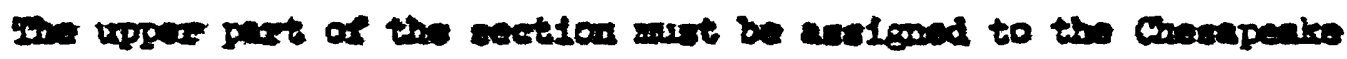

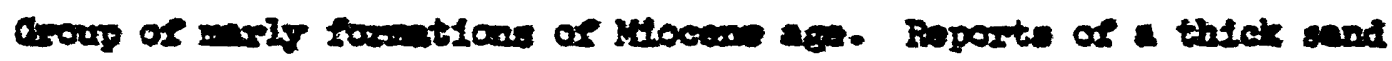
bal witht the Hecene (at 100 to 200 feot) is bot gutte bellevible. Bung up, this well wa doflied by the rotasy wethod and

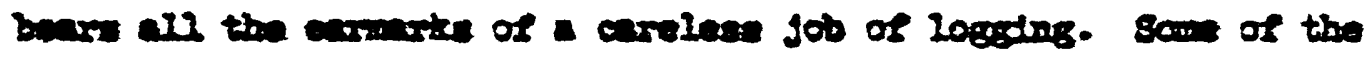

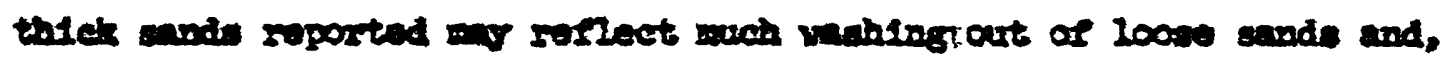

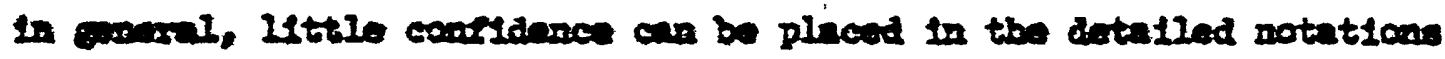
and.

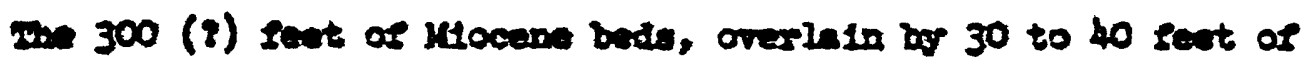

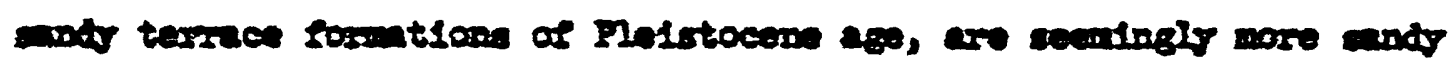

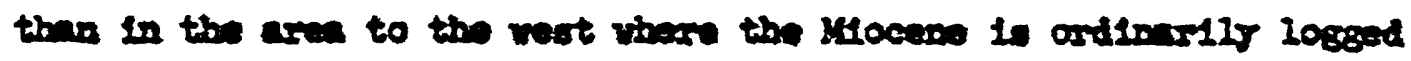
ex "mal" or blue elar." 
Dater Bewring Forwatlons

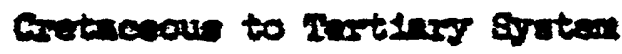

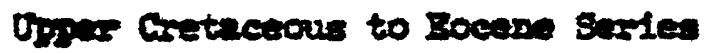

"Silt wente and sud" is supoerted at 1,920 and 1,945 feet in

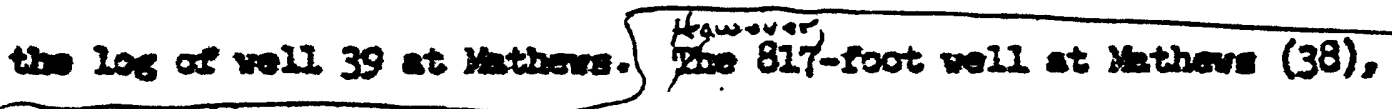

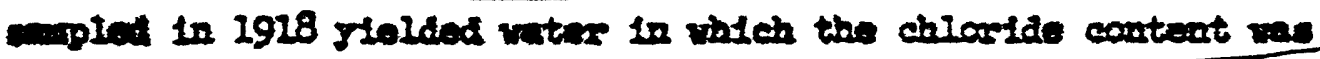

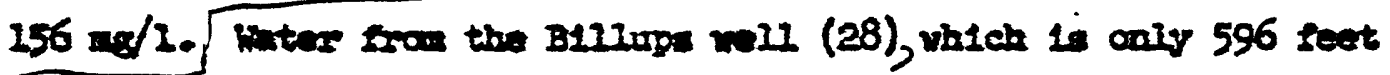

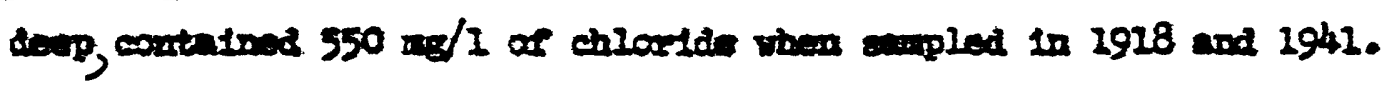

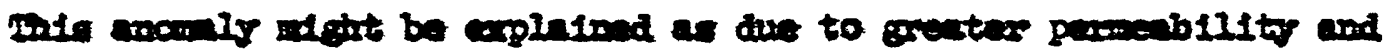

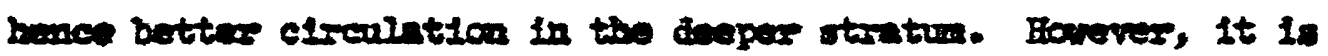

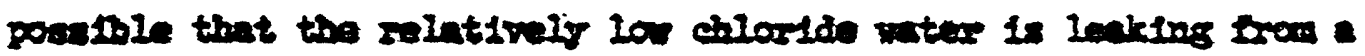

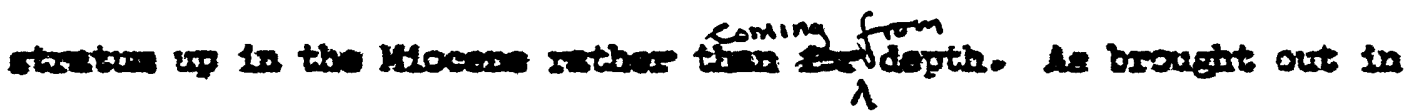

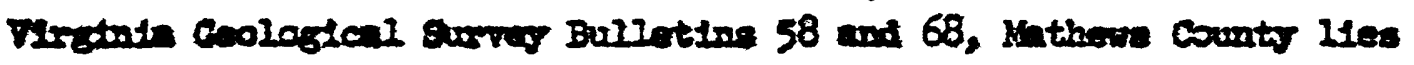

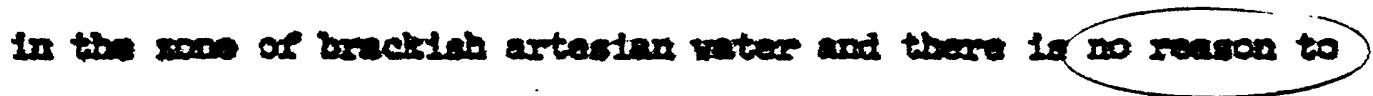

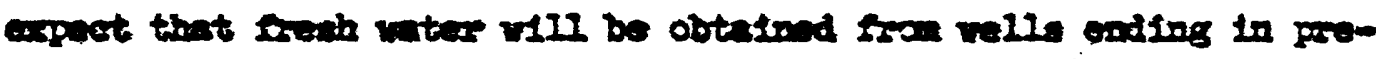

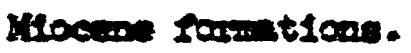

It if polnted out that thene is every reanon to belleve that

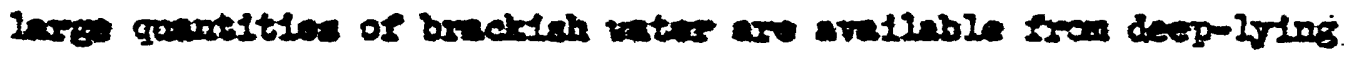

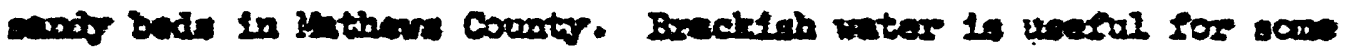

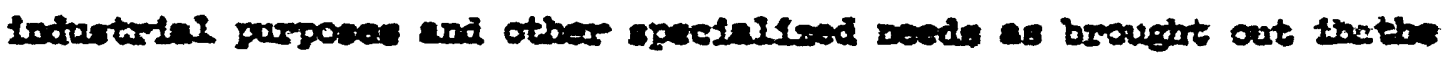
introductory abptes of this 20post.

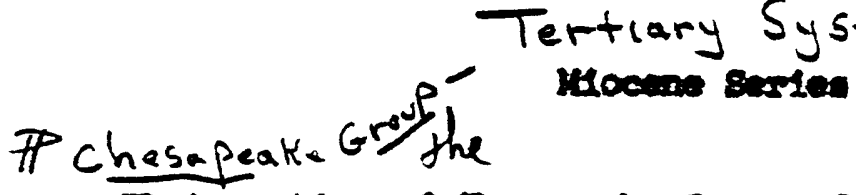

$$
\text { Tertiary Systom }
$$

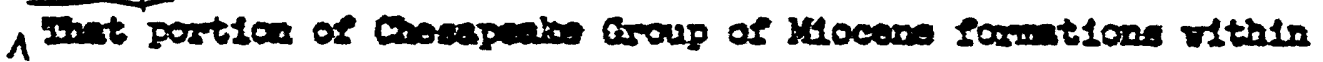
$\Lambda$

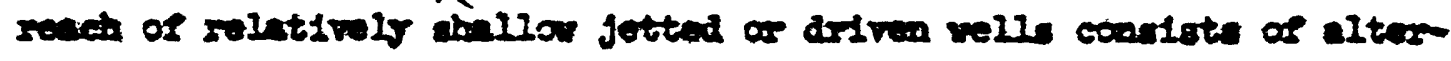

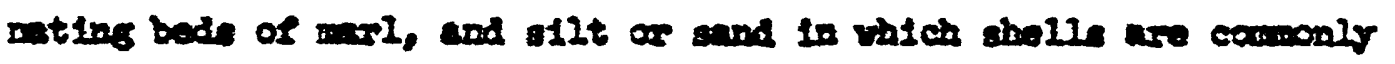
psovent. 


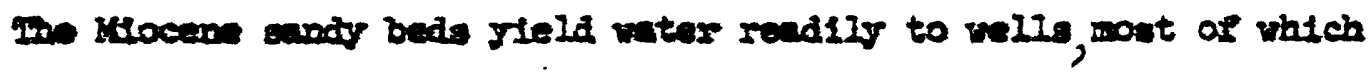

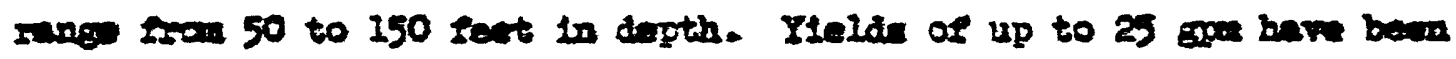
suportad from pines to gines.

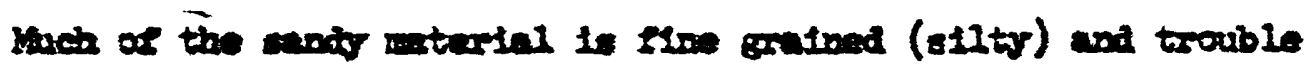

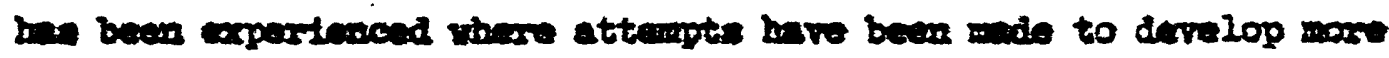

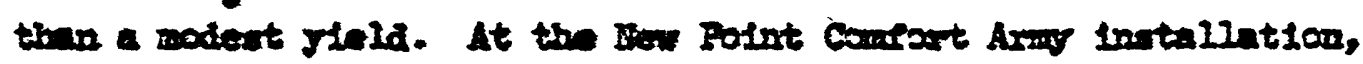
the elsot well conotructed (4a) intinily yleldad about $15 \mathrm{sg}$ of

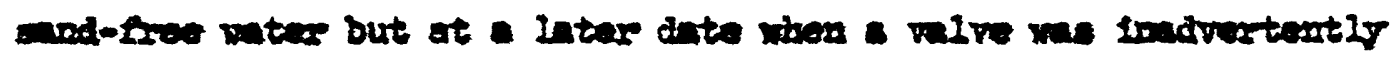

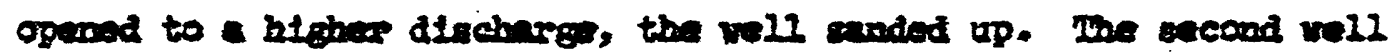

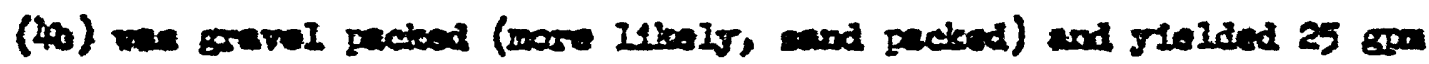
of sond-eree natres.

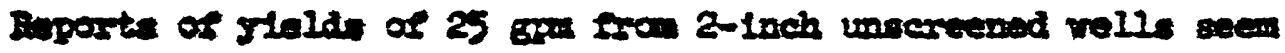

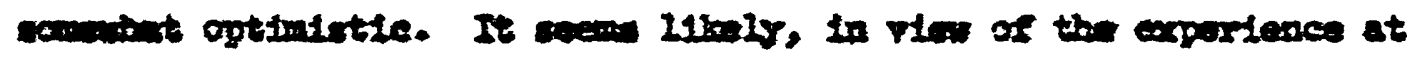

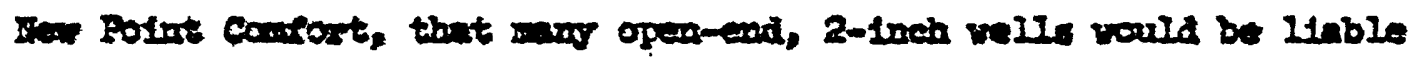

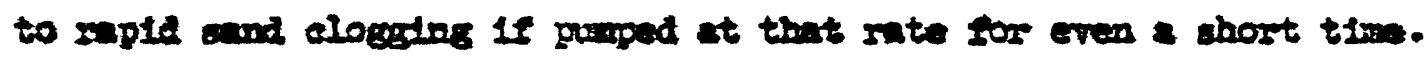
5ow (3T) at the conet Guare station on Gran Island is of

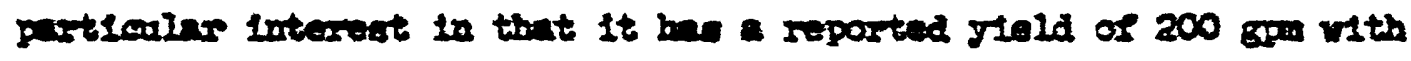

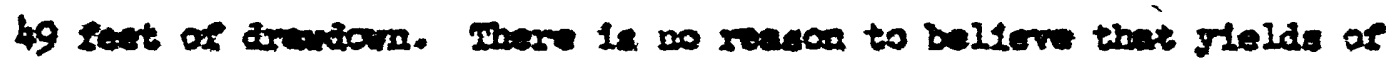

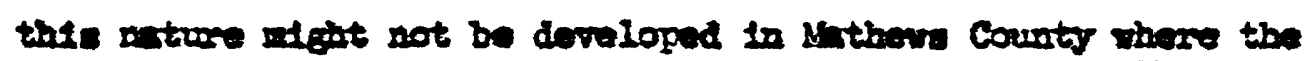
aquifer is convel. Eravel as opposed to and and s11t, is thought to bo present in oaly a fer placen in the county, altrough conrse and wo bos videly distributed. 


$$
\text { Quaternary Systom }
$$

Fledotocen sertes

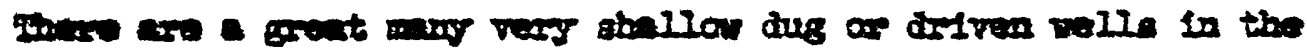

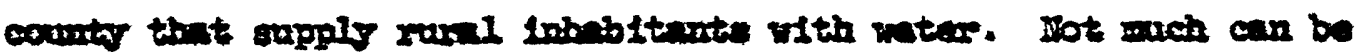

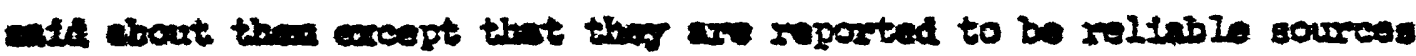
of vater one in times of drought.

\section{Oaltis of patar

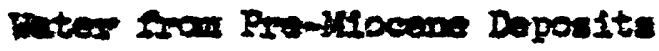

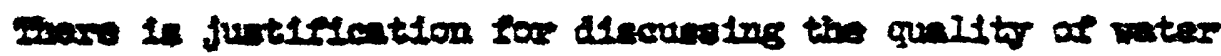

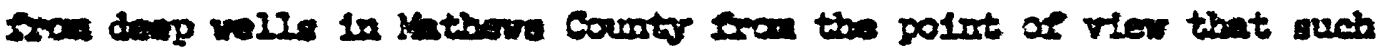

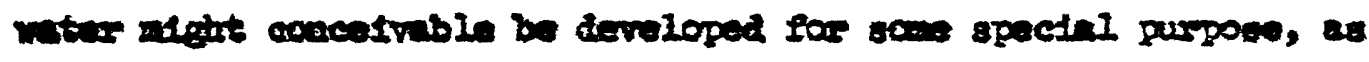

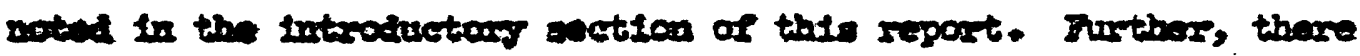

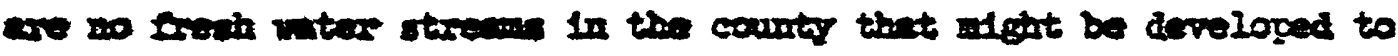
supply ivrge demande and if large suppltee vere to be developed by

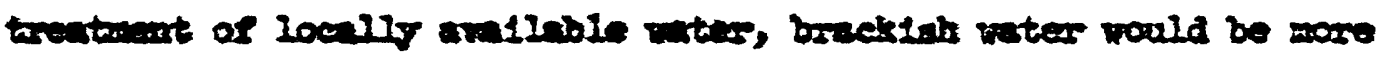

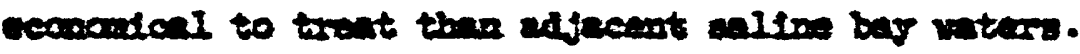

gow the 817-50ot well (38, tabla 18$)$ at

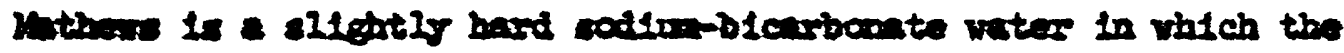

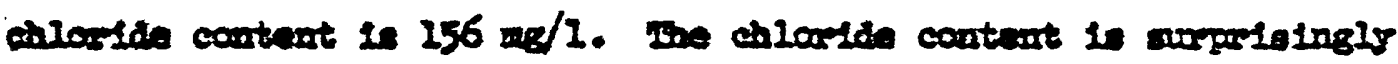
Ior and it is posstole that unders otead pumping conditions, the chloride content of the vater rould increase. At Yorktown, Virginin,

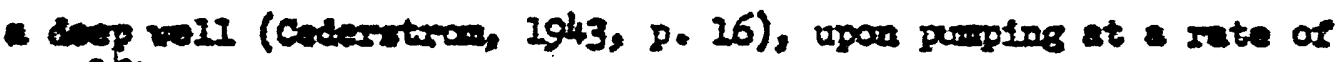

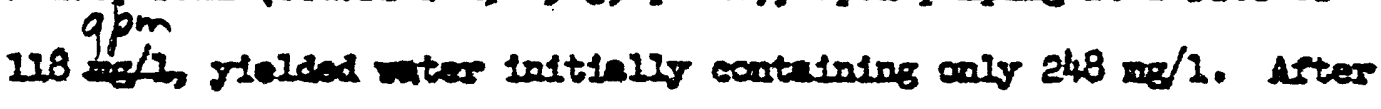

- short time, haveres, the chloride content rove to $440 \mathrm{mg} / 1$. - i 
Lfter a persid of sest the chloride centent swerted to fte former

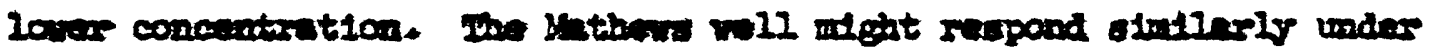
pumping condition if the rater is entaring the well at a depth of

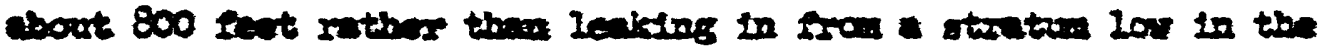
Howeresotion.

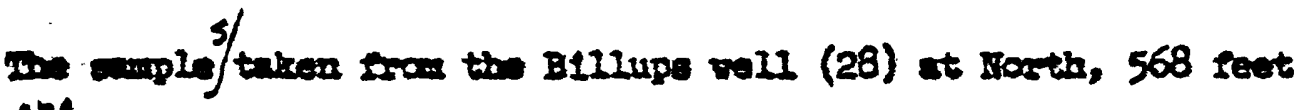
are

deap, It very mech the type that would be expected stom deep welle

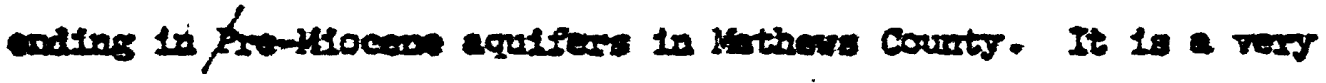

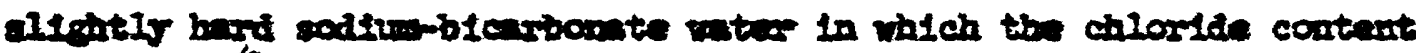

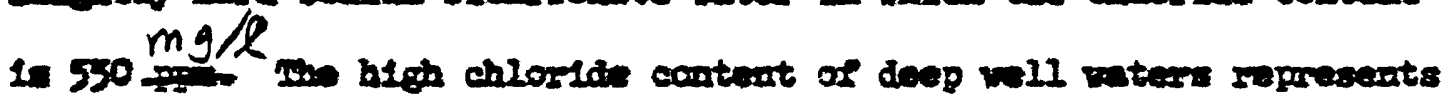

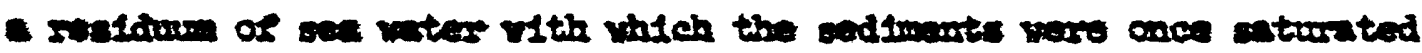
that bave not bean completels flushad out.

Becones of the hife rodivi ond low calcium content and bigh

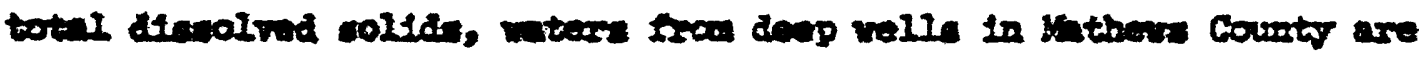
mpattable for irfontion uea. 
Water from Miocene Deposits

Water from Miocene deposits is characteristically a hard calcium bicarbonate type in which the chloride content is low or fairly low. The hardness of four samples taken from wells ending in Miocene beds (4a, 16, 40, 41) ranges from 136 to 279 but water from a fifth well (10) contained only 27 ofin hardness. Comparison of the analyses of the soft water (10) with an otherwise similar hard water (16) shows that the softer water has been softened by natural base exchange. The sample from well 41 is a hard water containing 268 of hardness. In this water the bicarbonate (in equivalents per million) is a little greater than the total hardness and, therefore, it has also been softened to some degree by base exchange.

The chloride in water from Miocene beds ranges from $10 \mathrm{mith}$ in well 4 to $136 \mathrm{mg} / \mathrm{k}$, in well 40 . The water containing 136 math of chloride is also high in bicarbonate, $640 \mathrm{ma} / 2 \mathrm{~g}$, and on that account may not be as pleasant tasting as water of lesser mineral content.

The chloride content of Miocene waters may be sea water remaining in those marine beds that has not been completely flushed out by infiltrating rain and snow melt. On the other hand, Mathews County is bordered by saline bay waters and there is every reason to believe that salt spray has added much or all of the sodium chloride present in Miocene (and Pleistocene) well waters. 


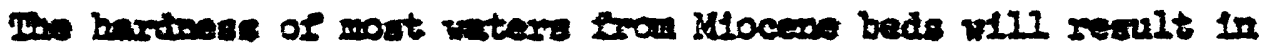

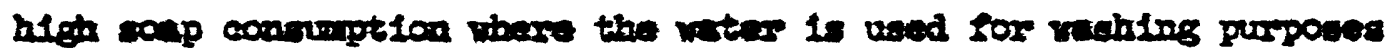

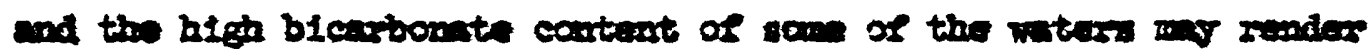

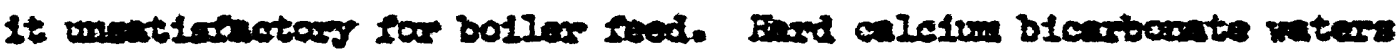

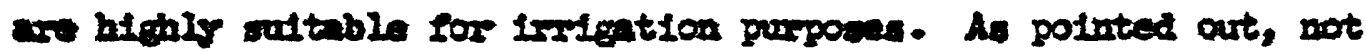

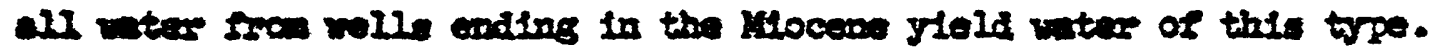

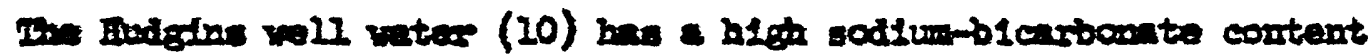

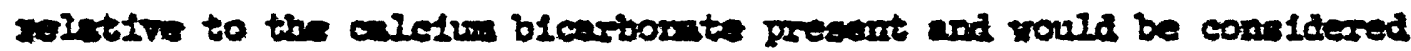

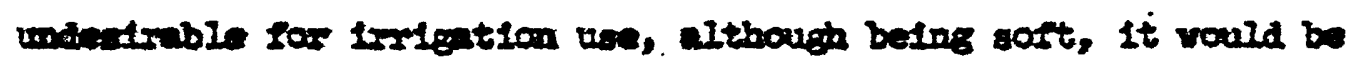

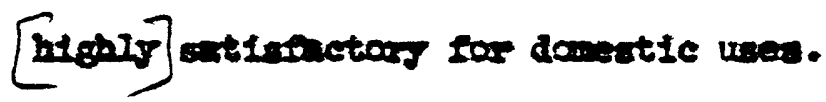

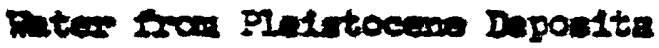

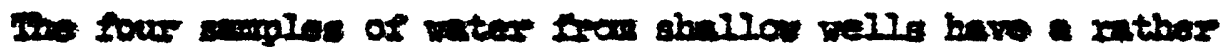

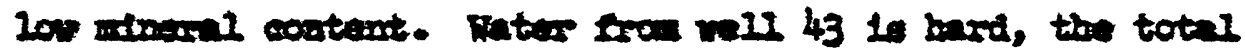

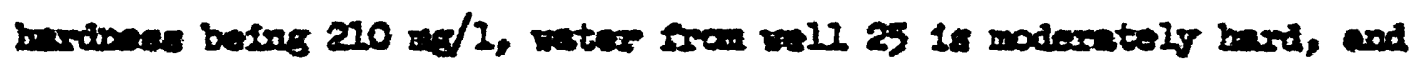

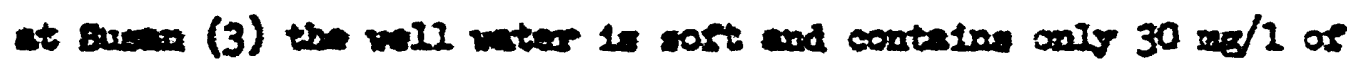

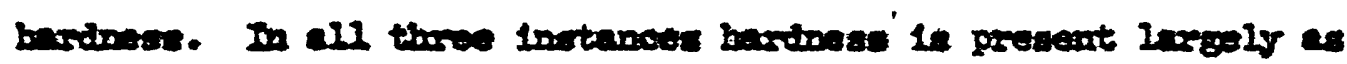

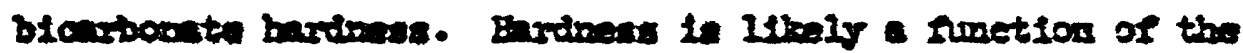

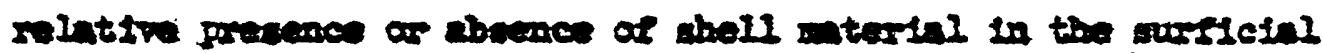

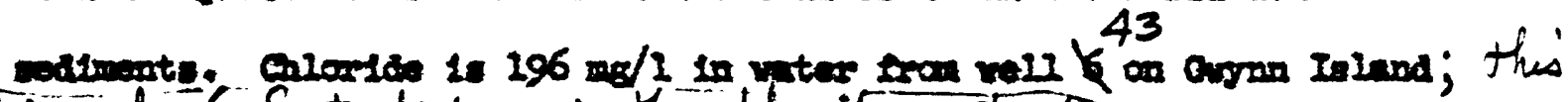
well is only 6 feet deep and the chloride content

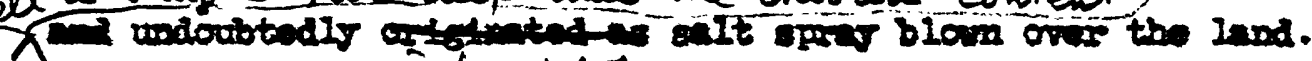
is deruied from 


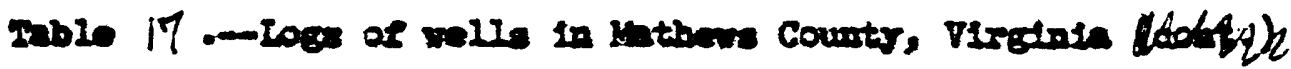

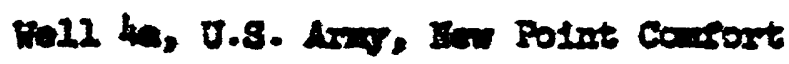

(200 D. I. Coderstion)

11t1tudi, 3 foot

Colmbin Group (Platotocena)

5op 2011

1

1

sind and olos, bard

3

4

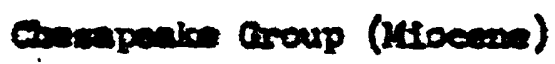

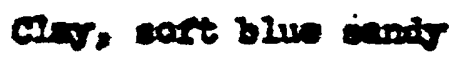

59

63

Qro, bard bive a11ty, with tom siollo

$\mathbf{T}$

70

ond and els, bart bles elits, with som abello

5

$\sqrt{3}$

gand and els, wortac, blve silts

83

sand, oreen elity

8

90

sud, ord oflty

$T$

120

sund, ons silty, tor sholls

30

136

sand and sholl, bard

16

150

senell rock

It

170

sand, oros enty

20

175 


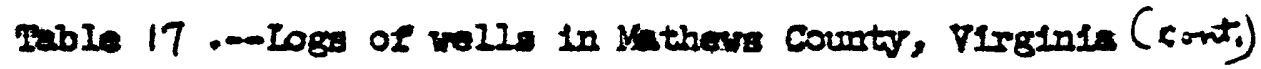
Wo1I \%, Do. J. H. Scherer, Dutchang's Polnt (LOB by sydoor Hydrodynsmics, ne

\section{Altitude S feot}

$\begin{array}{ll}\text { Thichosas } & \text { Dopth } \\ \text { (feet) } & \text { (feet) }\end{array}$

Columbia Group (Plerstocene)

Chesperake Group (Miocenc)

Marl, blue

shelle vith ond

50

65

vers, blue

35

100

abelis vith and

50

150

25

165

sund vith shell

20

173 


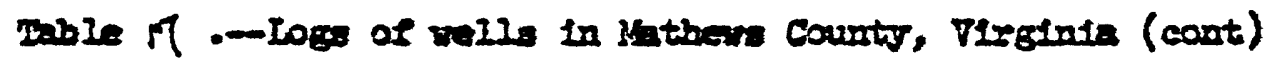
Full 39, Blien OLI and Cas Co., Mathors Altitude $T$ feet

$\begin{array}{ll}\text { Denfelonegs } & \text { Depth } \\ \text { (troet) } & \text { (feet) }\end{array}$

colimbia croup (Pleistecene)

Bund surence soll

Sund

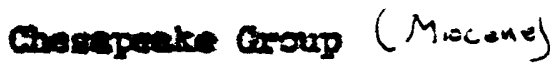

sond and ind

s.0.11

1200

Sund and sbell

100

200

o.t. I

20.

210

8nd

20

230

ondeffownentiated

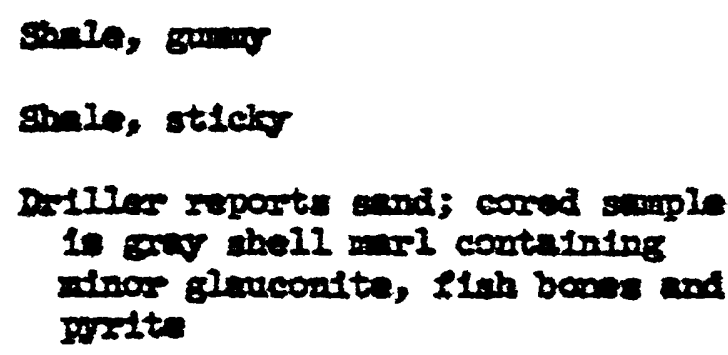

sind and govirl

sund, abell, and bouldien

Banle, andy

cumbo

stone

Shale, Bangos
270

90

10

500

60

$560-$

30

590

5

595

205

800

20

810

55 
Table iT .---Logs of wells in Mathews County, Virginia (cont.)

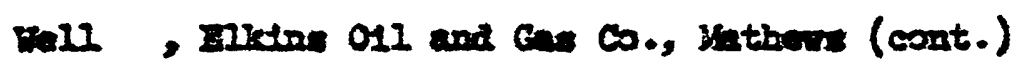

\begin{tabular}{|c|c|c|}
\hline . & 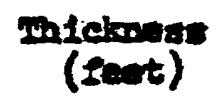 & $\begin{array}{l}\text { Depth } \\
\text { (feet) }\end{array}$ \\
\hline sond, groen gleweonitiongunts & 7 & 872 \\
\hline sond, hard, and profted & 2 & 873 \\
\hline 8ma, gren & 5 & 878 \\
\hline sant & 3 & 881 \\
\hline Cumbo & It & 895 \\
\hline 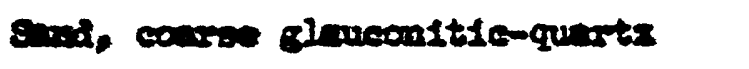 & 7 & 902 \\
\hline $\sin$ & 8 & 910 \\
\hline$a \rightarrow \infty$ & $T$ & 917 \\
\hline $\sin$ & 218 & 1035 \\
\hline $\sin 10$ & 15 & 1050 \\
\hline $\sin$ & 35 & 1085 \\
\hline onsesen & 3 & 2090 \\
\hline Dand and and & 20 & 21210 \\
\hline 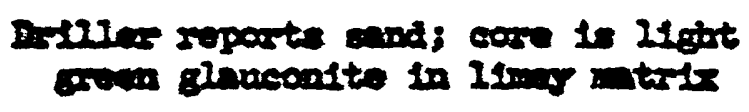 & 12 & 1122 \\
\hline exios & 38 & 1160 \\
\hline 8 & 15 & 1375 \\
\hline coniso & 40 & 1215 \\
\hline gand and blect sand & 5 & 2220 \\
\hline oner, sads, and abell & 60 & 2280 \\
\hline Ormibo & 54 & 2334 \\
\hline send & 2 & 1335 \\
\hline Sad, trace of elaveonst to & 75 & 1410 \\
\hline
\end{tabular}


Table 17 .--Logs of wells in Mathews County, Virginia (cont.)

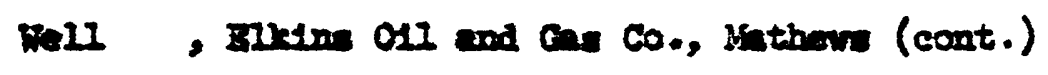

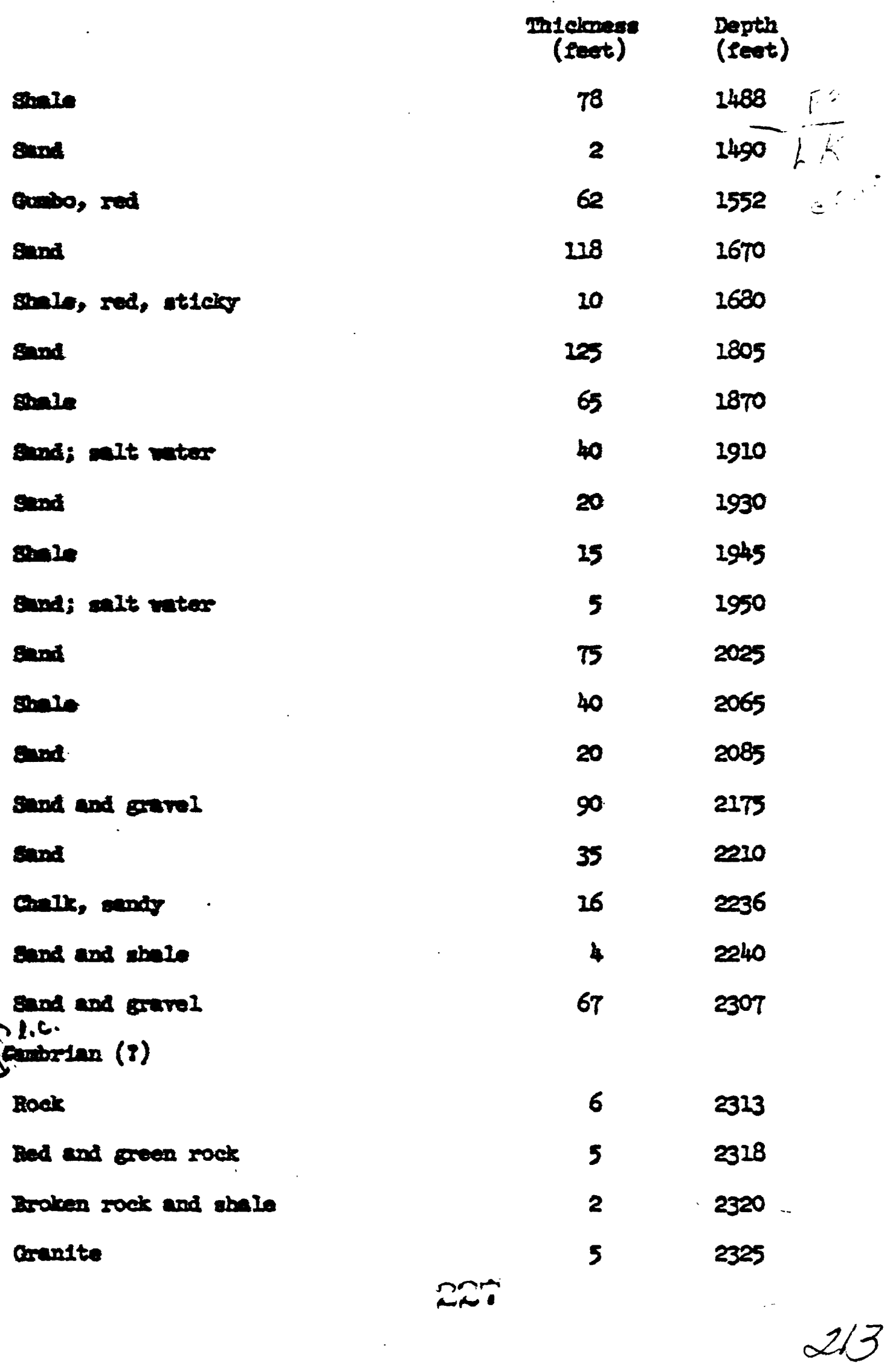




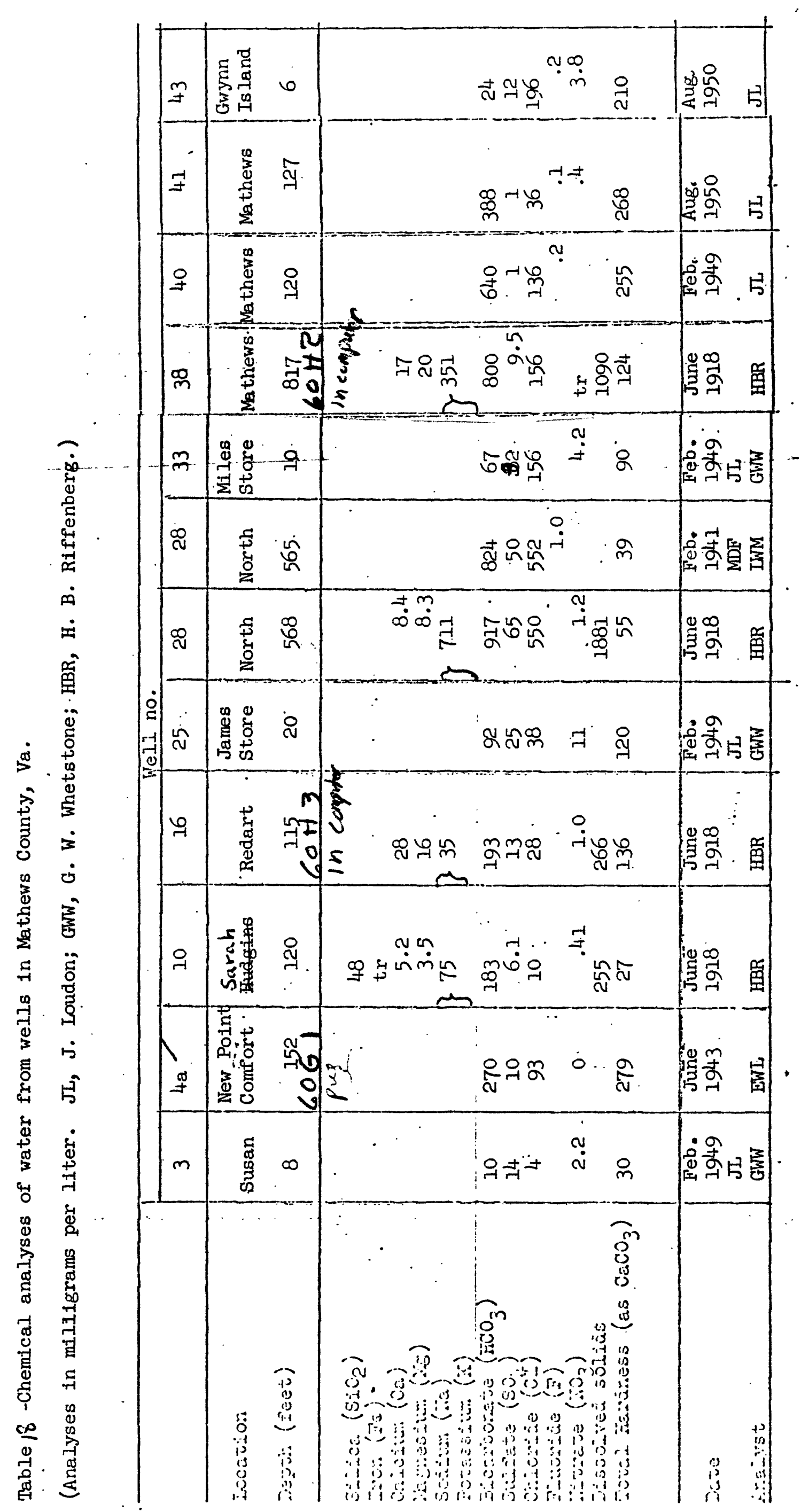

228 


\section{Rasurancees}

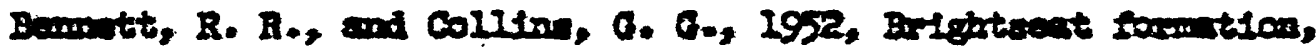

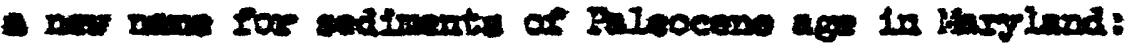

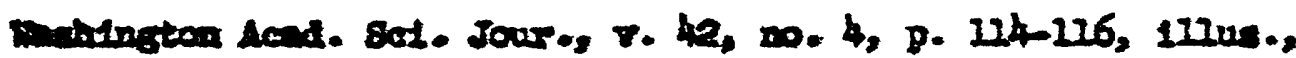
Apro.

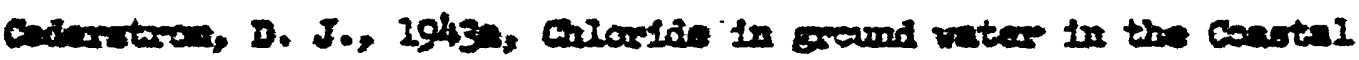

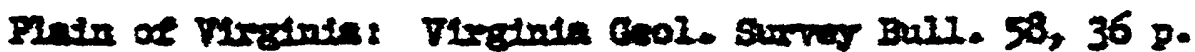
19450. Bap wils in the contal Flain of Virgindes Ve. Gol.

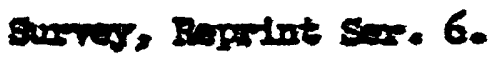

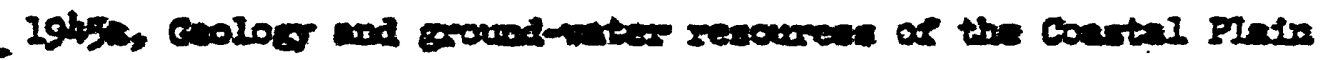

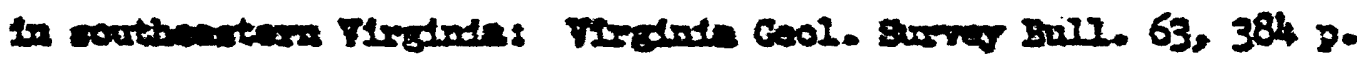

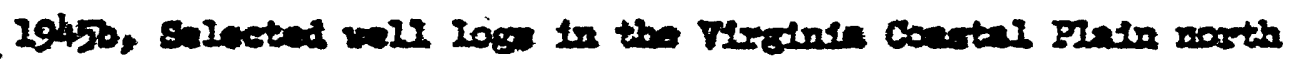

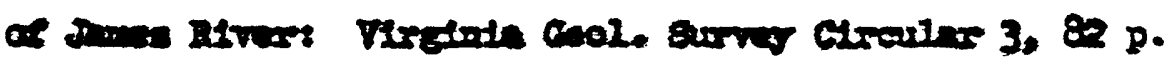

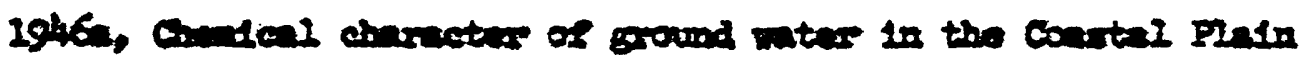

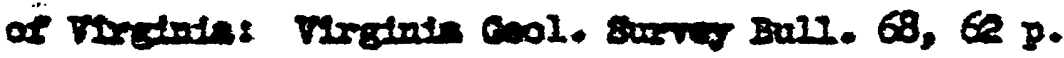

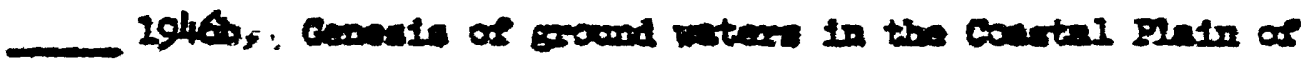

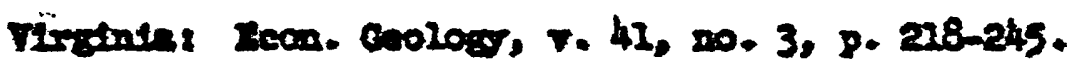

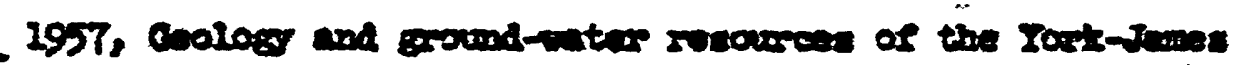

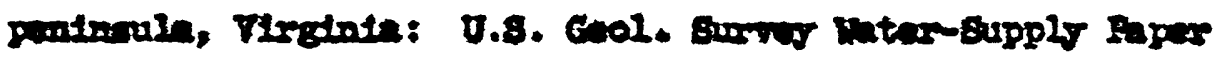
2361. $237 \mathrm{p}$. 
19570, Consiation of the Cols and Atinntio contal pinto

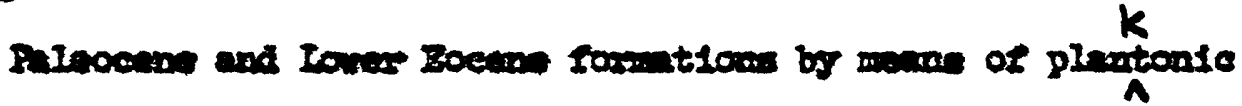

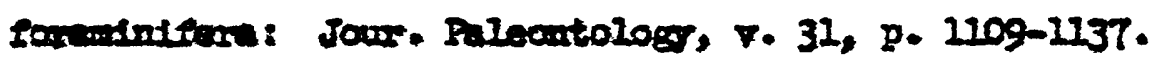
E

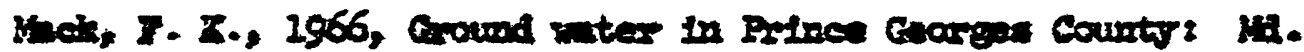
Borl. Exrow, Ball. 29 .

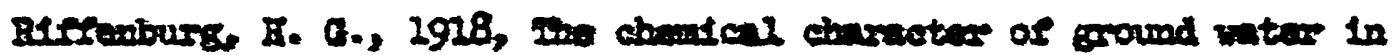

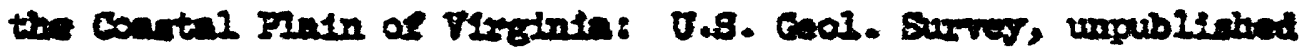
memecerptio.

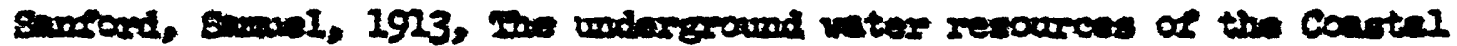

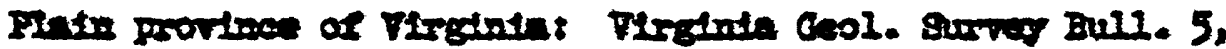
361 .

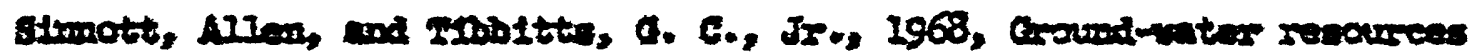

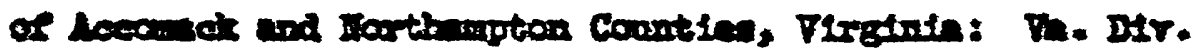

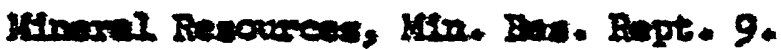

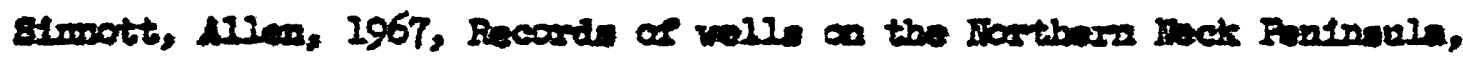
Virginla: 0.8. Geol. Bunas open-rile report.

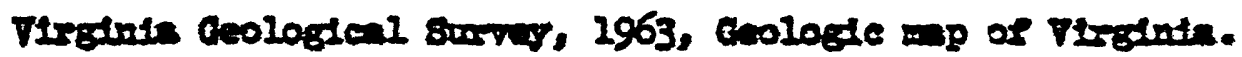

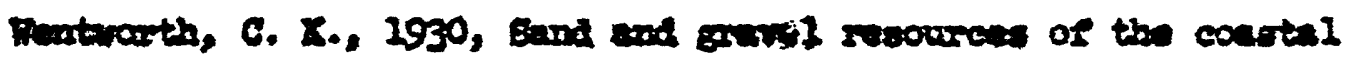
plain of Virginta: Virgenta ceol. Surva Bull. 32, $146 \mathrm{p}$. 